\author{
UNIVERSIDADE DE SÃO PAULO \\ FACULDADE DE FILOSOFIA, LETRAS E CIÊNCIAS HUMANAS \\ DEPARTAMENTO DE CIÊNCIA POLÍTICA \\ PROGRAMA DE PÓS-GRADUAÇÃO EM CIÊNCIA POLÍTICA
}

GABRIEL LUAN ABSHER BELLON

\title{
Constituições Estaduais pós-1989: \\ O Processo de Emendamento e seus Determinantes
}

(Versão Corrigida)

São Paulo

2016 


\author{
UNIVERSIDADE DE SÃO PAULO \\ FACULDADE DE FILOSOFIA, LETRAS E CIÊNCIAS HUMANAS \\ DEPARTAMENTO DE CIÊNCIA POLÍTICA \\ PROGRAMA DE PÓS-GRADUAÇÃO EM CIÊNCIA POLÍTICA
}

Constituições Estaduais pós-1989:

O Processo de Emendamento e seus Determinantes

(Versão Corrigida)

Gabriel Luan Absher Bellon

Dissertação apresentada ao Programa de Pós-Graduação em Ciência Política do Departamento de Ciência Política da Faculdade de Filosofia, Letras e Ciências Humanas da Universidade de São Paulo para obtenção de Mestre em Ciência Política

Orientador: Prof. Dr. Rogério Bastos Arantes

São Paulo

2016 
Autorizo a reprodução e divulgação total ou parcial deste trabalho, por qualquer meio convencional ou eletrônico, para fins de estudo e pesquisa, desde que citada a fonte.

Catalogação na Publicação

Serviço de Biblioteca e Documentação

Faculdade de Filosofia, Letras e Ciências Humanas da Universidade de São Paulo

B 447 C

Bellon, Gabriel Luan Absher

Constituições Estaduais pós-1989: O Processo de Emendamento e seus Determinantes / Gabriel Luan

Absher Bellon ; orientador Rogério Bastos Arantes. São Paulo, 2015.

$193 \mathrm{f}$.

Dissertação (Mestrado) - Faculdade de Filosofia, Letras e Ciências Humanas da Universidade de São Paulo. Departamento de Ciência Política. Área de concentração: Ciência Política.

1. Emenda Constitucional. 2. Assembleia Legislativa. 3. Políticas Públicas. 4. Federalismo. 5. Governo e Constitucionalidade. I. Arantes, Rogério Bastos, orient. II. Título. 


\section{Folha de Aprovação}

Gabriel Luan Absher Bellon

Constituições Estaduais pós-1989: O Processo de Emendamento e seus Determinantes

Dissertação apresentada ao Programa de Pós-Graduação em Ciência Política do Departamento de Ciência Política da Faculdade de Filosofia, Letras e Ciências Humanas da Universidade de São Paulo para obtenção de Mestre em Ciência Política

Orientador: Prof. Dr. Rogério Bastos Arantes

Aprovado em:

Banca Examinadora

Prof. Dr. Instituição:

Assinatura: Julgamento:

Prof. Dr. Instituição:

Assinatura: Julgamento:

Prof. Dr. Instituição:

Assinatura: Julgamento: 


\section{Agradecimentos}

Este trabalho foi elaborado com a ajuda e auxílio de inúmeras pessoas a quem sou grato. Inicialmente agradeço ao meu orientador, Rogério Arantes, não só pela orientação dedicada mas também pela paciência e perseverança. Seu apoio e principalmente incentivo possibilitaram o desenvolvimento desta dissertação.

Agradeço também ao professor Cláudio Couto por despertar meu interesse no tema que deu origem a esta dissertação.

Finalmente agradeço aos meus irmãos e cunhada pelo apoio e incontáveis horas de trabalho de revisão e edição, e aos meus pais pelo incentivo e compreensão. 


\section{Resumo}

Esta dissertação pretende contribuir para o conhecimento de dimensões pouco estudadas do processo político estadual, especialmente a política constitucional nos estados brasileiros. Propomos estudar então o processo de emendamento às Constituições Estaduais. Para tanto levantamos os textos das Constituições Estaduais promulgadas após 1989 e suas emendas aprovadas entre 1989 e 2014. A partir dos dados levantados desenvolvemos uma análise descritiva das Constituições e das Emendas aprovadas com o objetivo de identificar padrões e características do constitucionalismo estadual. Além da análise descritiva também comparamos três unidades de medida de extensão constitucional, a quantidade de artigos, de palavras e de dispositivos. Nas análises descritivas encontramos variabilidade tanto na extensão Constitucional quanto no tamanho do emendamento. A fim de identificar fenômenos associados à variabilidade no emendamento desenvolvemos uma análise simplificada em que optamos por modelos estáticos e bivariados. Dentre os testes efetuados destacamos três resultados. A constitucionalização de políticas públicas parece afetar significativamente o emendamento de forma que parte do processo legislativo utiliza a alteração constitucional para avançar a agenda. A maior fragmentação do sistema político leva a aprovação de emendas mais extensas. $E$ finalmente que parte do emendamento às Constituições Estaduais é explicado pelas alterações efetuadas à Constituição Federal.

Palavras-Chave: Constituições Estaduais; Alteração Constitucional; Federalismo. 


\begin{abstract}
Our main purpose in this master's thesis is advancing the research on Brazilians state politics not yet adequately studied, mainly the state constitutional policy. Therefore, we intend an analysis on the amendment process of state Constitutions. Our first step was gathering the state Constitutions and their amendments between 1989 and 2014 and performing an exploratory descriptive analysis. Along with the descriptive analysis, we perform comparisons amongst three methods of measuring constitutional length, the number of articles, number of words and number of constitutional provisions. As a result of the exploratory analysis, we found considerable variability on state constitutional and amendment length. In order to identify possible phenomena related to amendment variability we perform a simplified analysis based on static and bivariate models. Amongst the performed tests, three results are noteworthy. The amount of public policies on Constitutional texts seem to increase the amendment. Higher party system fragmentation correlates with lengthier approved amends. Lastly, the state constitutional change shows an echo of the Federal Constitutional amendments.
\end{abstract}

Keywords: State Constitutions; Constitutional Amendment; Federalism 


\section{Lista de Gráficos}

Gráfico 2.1 - Extensão, em artigos, das Constituições Estaduais .........................................39

Gráfico 2.2 - Extensão, em palavras, das Constituições Estaduais........................................43

Gráfico 2.3 - Extensão, em dispositivos, das Constituições Estaduais...................................46

Gráfico 2.4 - Proporção média dos trechos desagregados nas três unidades de medida.....50

Gráfico 2.5 - Extensão das Constituições Estaduais nas três unidades de medida com

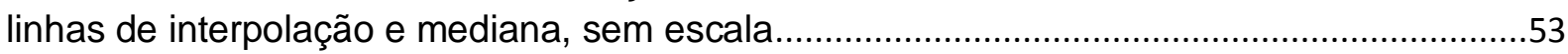

Gráfico 2.6 - Extensão Constitucional com medidas transformadas.......................................54

Gráfico 2.7 - Matriz de gráficos de dispersão entre as medidas de extensão Constitucional

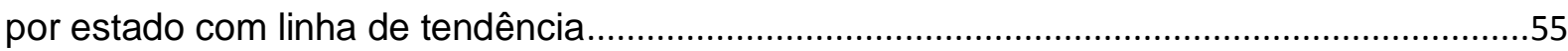

Gráfico 2.8 - Extensão total dos Títulos Padronizados nas Constituições Estaduais.............63

Gráfico 2.9 - Extensão Média nas Constituições Estaduais com indicação de desvio padrão

e da Constituição Federal, por Título

Gráfico 2.10 - Proporção Relativa dos Títulos na média das Constituições estaduais e na

Constituição Federal.

Gráfico 2.11 - Composição relativa das Constituições Estaduais, Constituição Federal e

Constituição Estadual Média...

Gráfico 3.1 - Total de Emendas Promulgadas por UF ..........................................................76

Gráfico 3.2 - Total de Dispositivos de Emenda Promulgados por UF ...................................83

Gráfico 3.3 - Gráfico de Dispersão de Dispositivos x Emendas .............................................86

Gráfico 3.4 - Total de emendamento Estadual e Federal ao Ano...........................................87

Gráfico 3.5 - Média de Dispositivos de Emenda Promulgados ao ano com um desvio

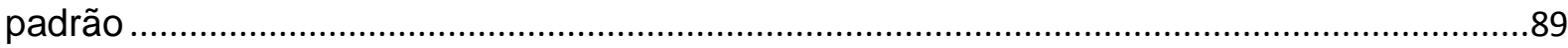

Gráfico 3.6 - Total de Dispositivos de Emenda Estadual por Título Padronizado..................92

Gráfico 3.7 - Dispositivos por Título, Média Estadual e Total Federal ...................................94

Gráfico 3.8 - Emendamento agregado nos Estados e União, proporcional aos Títulos........95

Gráfico 3.9 - Emendamento agregado nos Estados e União, proporcional aos Títulos ........97

Gráfico 3.10 - Emendamento Anual, proporcional aos Títulos ...........................................99

Gráfico 3.11 - Total de Dispositivos de Emenda por tipo de emendamento.........................102

Gráfico 3.12 - Proporção do Tipo de Emendamento por Ente Federativo..............................105

Gráfico 3.13 - Proporção de Tipo de Emendamento por UF mais União .............................106

Gráfico 3.14 - Tipo de Emendamento ao Ano ......................................................................107

Gráfico 3.15 - Proporção de Tipo de Emendamento ao Ano ..............................................109

Gráfico 3.16 - Proporção de Tipo de emendamento por Título, total Estadual e Federal ...110

Gráfico 3.17 - Total de Dispositivos de Emenda por Ator Proponente...................................116

Gráfico 3.18 - Proporção de Dispositivos de Emenda por Ator Proponente em cada UF ...117

Gráfico 3.19 - Emendamento Anual, categorias por Origem Institucional ...........................118

Gráfico 3.20 - Participação dos Atores Institucionais no Emendamento por Título, total

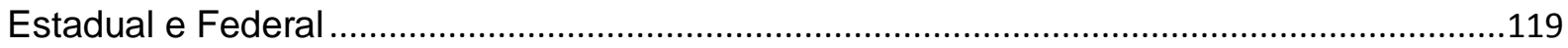

Gráfico 3.21 - Tipo de Emendamento por Ator Institucional, total Estadual e Federal ........120

Gráfico 3.22 - Proporção dos Atores Proponentes por Tipo de Emendamento, total Estadual

e Federal.....

Gráfico 4.1 - Gráficos de Dispersão entre Dispositivos de Emenda e Variáveis Contextuais

Gráfico 4.2 - Gráfico de Dispersão entre tamanho das Constituições Estaduais e seus Emendamentos 
Gráfico 4.3 - Gráfico de Dispersão entre o Emendamento e o total de Policies

Constitucionalizadas .

Gráfico 4.4 - Gráficos de Dispersão entre o Emendamento anual nos Estados e União....144

Gráfico 4.5 - Gráficos de Dispersão da Força do Governador. .148

Gráfico 4.6 - Gráficos de Dispersão entre Emendamento e Fragmentação Política . 149

Gráfico A.1 -Gráficos exploratórios e descritivos da quantidade de artigos 165

Gráfico A.2 - Gráficos exploratórios e descritivos da quantidade de palavras (em 1.000). 168 Gráfico A.3 - Gráficos exploratórios e descritivos da quantidade de dispositivos nas

Constituições Estaduais.

Gráfico A.4 - Histogramas de Frequência Relativa da extensão, em dispositivo, dos Títulos

Padronizados 184

Gráfico A.5 - Diagramas de Caixa da Quantidade de Dispositivos por Título nas

Constituições Estaduais 185 


\section{Lista de Tabelas}

Tabela 2.1 - Data de Promulgação das Constituições Estaduais ..........................................34

Tabela 2.2 - Medidas de Dispersão Relativa na Constituição e por trecho desagregado ......49

Tabela 2.3 - Média, máximo e mínimo dos artigos Constitucionais .........................................51

Tabela 2.4 - Coeficientes de Correlação entre as unidades de medida ...................................56

Tabela 3.1 - Regras de Proposição e Aprovação de Emendas às Constituições Estaduais .72

Tabela 3.2 -Tamanho do Emendamento por Unidade Federativa (1989-2014) ....................77

Tabela 3.3 - Dispositivos de Emenda promulgados por Unidade Federativa (1989-2014) ....84

Tabela A.1 - Medidas descritivas da Extensão Constitucional medida em artigos. .............164

Tabela A.2 - Medidas descritivas da Extensão Constitucional medida em palavras ...........167

Tabela A.3 - Medidas descritivas da Extensão Constitucional medida em dispositivos. .....174

Tabela A.4 - Sumário estatístico das variáveis transformadas ...........................................177

Tabela A.5 - Médias e Desvios Padrão da quantidade de dispositivos por Título.................180

Tabela A.6 - Resultados do teste post hoc de Games-Howell para quantidade de dispositivos por Título.

Tabela A.7 - Sumário Estatístico da extensão, em dispositivos, dos Títulos Padronizados183

Tabela A.8 - Estatísticas Descritivas das Variáveis Desentendes e Independentes

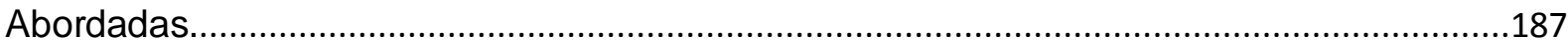

Tabela A.9 - Hipóteses 1 e 2, coeficientes de Correlação ......................................................188

Tabela A.10 - Hipóteses 3 e 4, coeficientes de Correlação....................................................188

Tabela A.11 - Hipótese 5, coeficientes de Correlação ..........................................................188

Tabela A.12 - Hipótese 6, coeficientes de Correlação ……...............................................189

Tabela A.13 - Hipótese 7, coeficientes de Correlação ……...................................................189 


\section{Sumário}

1. Introdução: Federalismo, constituições e emendamento constitucional nos

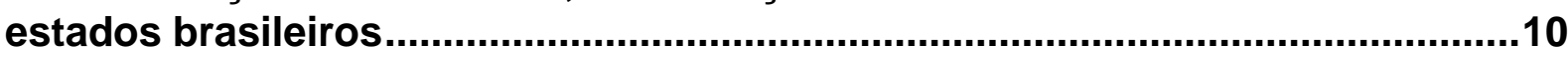

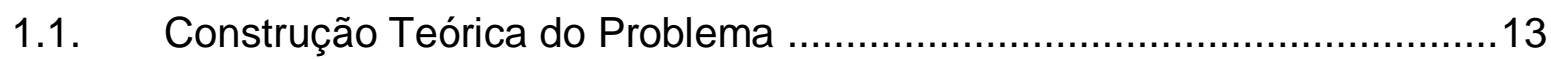

1.1.1. Constituição Federal e as Constituições Estaduais ...............................13

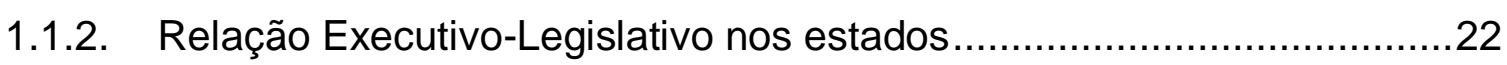

1.2. Primeiras tentativas de explicação do emendamento ...............................25

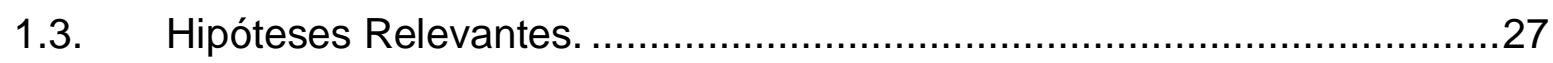

2. Análise Descritiva das Constituições Estaduais .........................................33

2.1. Promulgação das Constituições Estaduais ...........................................33

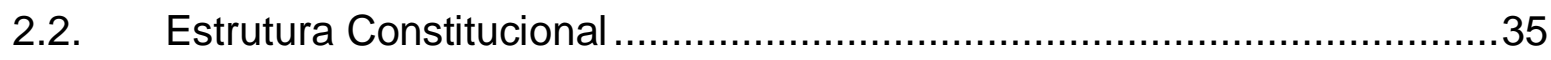

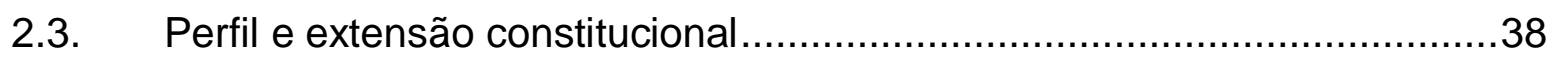

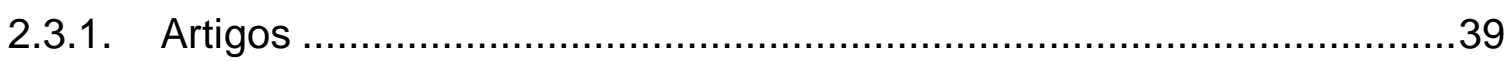

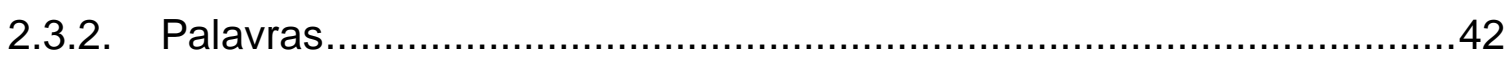

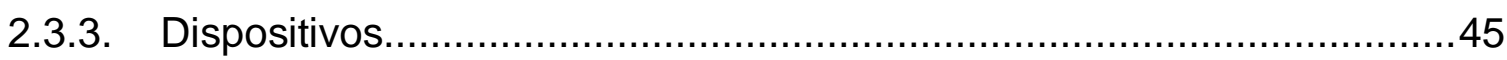

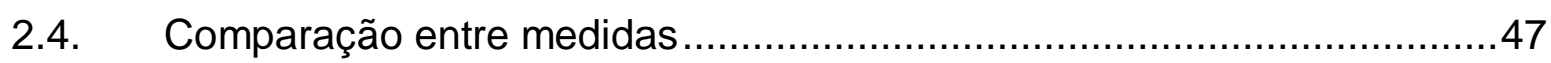

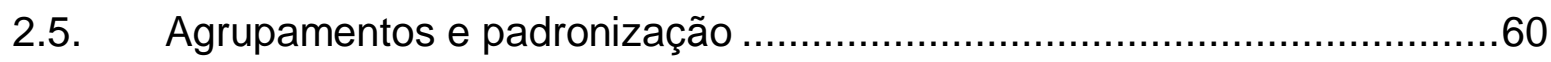

3. Emendamento constitucional nos estados .................................................71

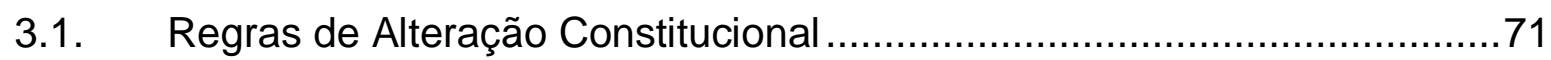

3.2. Quantificação do Emendamento Constitucional ....................................75

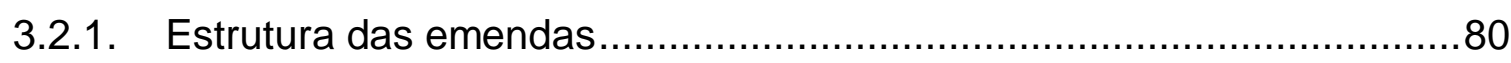

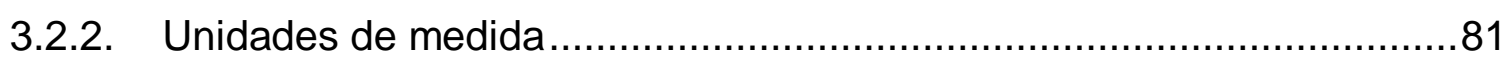

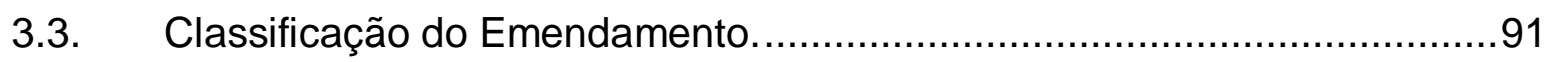

3.3.1. Emendamento por tema …........................................................

3.3.2. Natureza do Emendamento ........................................................100

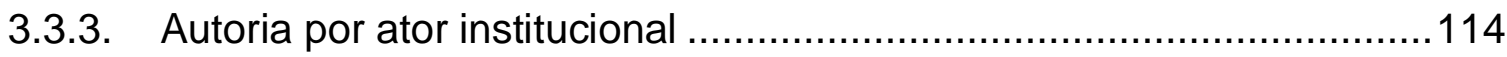

3.4. Impacto do emendamento sobre o texto original ...............................122

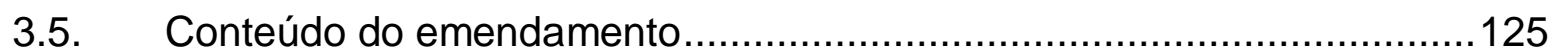

4. Determinantes do Emendamento Estadual ................................................131

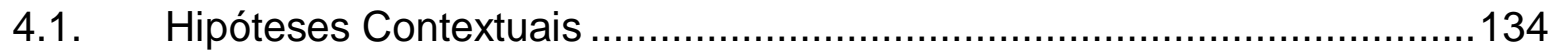

4.2. Hipóteses Institucionais .........................................................137

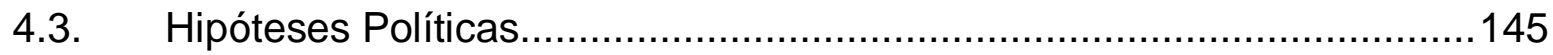

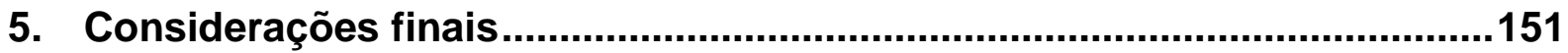

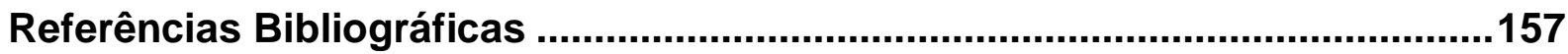


Apêndice A - Características das variáveis 162

A.1 Opções metodológicas na definição das variáveis 162

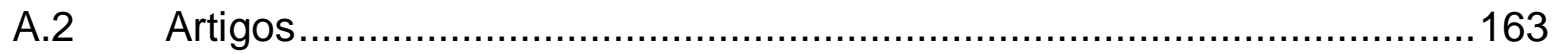

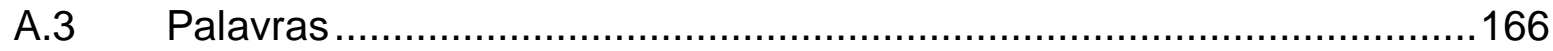

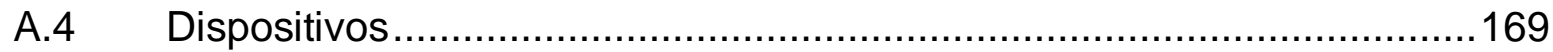

A.5 Comparação entre as variáveis ………......................................177

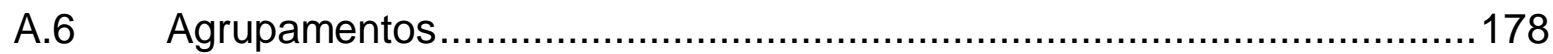

A.7 Estatísticas das Hipóteses avaliadas .............................................186

Apêndice B - Modelo de Questionário de Coalizão.....................................190 


\section{Introdução: Federalismo, constituições e emendamento constitucional nos estados brasileiros}

O estado brasileiro é marcado por um federalismo no qual três entes coexistem. Idealmente esses três entes deveriam operar em áreas de atuação específicas bem como cooperar e compartilhar responsabilidades em outras. Com a promulgação da Constituição de 1988 o sistema brasileiro fica marcado por um arranjo institucional cujos impactos e consequências não são claramente observáveis de início. É verdade que num primeiro momento surgiram as teses de que a federação fora descentralizada, mas em seguida essa visão foi contestada em prol de uma avaliação de que a federação tornara-se mais centralizadora. $\mathrm{O}$ argumento central dessa segunda visão é o de que a União concentra boa parte dos poderes e capacidades de legislação e implementação de políticas públicas, em detrimento das demais esferas da federação. Dada essa visão de estado centralizador, boa parte dos estudos desenvolvidos sobre funcionamento do legislativo brasileiro se focaram sobre a legislação federal, tanto Constitucional quanto infraconstitucional, bem como sobre as relações executivo/legislativo no nível federal. No entanto, ao focar apenas os instrumentos federais, a dinâmica subnacional, especialmente a estadual, foi relegada a segundo.

A ideia de federalismo fraco com estados subservientes à União vem sendo cada vez mais contestada. Por um lado (SOUZA, 2004, 2005) afirma que o arranjo institucional adotado na Constituição de 88, por mais centralizador que seja, não removeu a totalidade dos poderes de agenda do nível estadual. Estudos anteriores (ABRÚCIO, 1998; STEPAN, 1999) já haviam defendido, por outro lado, que por mais que o poder estadual não seja tão reduzido, é altamente controlado pelo executivo local. E por consequência teria ampla capacidade de intervir no legislativo e resistir ao executivo nacional. Tal abordagem também vem sendo contestada, já que não só a capacidade de governadores determinarem a agenda em nível federal não é observada, como o próprio poder dos governadores dentro de seus estados começa a ser relativizado. Estudos mais recentes mostram que a heterogeneidade na produção legislativa nos estados brasileiros permite concluir que não há um padrão absoluto (NUNES, 2009; SANDES-FREITAS; MASSONETTO, 2012; SANTOS, 2001; 
SILVA, 2012, 2013; TOMIO; RICCI, 2012a, 2013b) Em alguns estados os governadores possuem mais poder, em outros menos. Assim o arranjo institucional não garantiu a primazia absoluta do executivo sobre o legislativo.

Dentro desse contexto de disputa legislativo/executivo e nacional/estadual, a Constituição de 1988 é considerada a instituição formal que baliza as relações tanto entre os poderes quanto entre os entes federativos. Ademais, essa Carta apresenta como característica marcante a grande extensão e constitucionalização de aspectos que usualmente não seriam encontrados em uma constituição dita tradicional. Ou seja, a Carta de 1988 eleva a marco constitucional uma série de políticas públicas e particularismos incluídos pelos constituintes, o que enseja uma dinâmica de emendamentos constantes e a necessidade de se governar em nível constitucional.

A Constituição de 1988 estabelece que os estados se balizem por meio de constituições próprias que respeitarão os princípios estabelecidos no documento maior. Com isso as constituições estaduais de 1989 são promulgadas e acabam por refletir a Carta de 1988 não só em termos de princípios, mas frequentemente com trechos inteiros transcritos com a alteração de apenas algumas palavras, usualmente fazendo a correspondência dos termos para se referir à organização estadual. Esse princípio de simetria adotado na promulgação das cartas de 1989 fará então com que estas repitam os mesmos vícios e virtudes do documento maior.

Após mais de duas décadas da promulgação das Constituições Estaduais pouco sabemos sobre elas. O foco dos estudos encontrados na literatura se dá sobre a Constituição Federal, sendo comum a afirmação no debate público que as constituições estaduais basicamente copiaram o modelo da Carta de 1988. Dito de outra forma, são por vezes consideradas normas simbólicas copiadas da Constituição Federal sem funcionalidade ou impacto local, mas sequer essa ideia foi objeto de demonstração rigorosa. Mesmo que tal hipótese não tenha sido testada, sua enunciação levanta questões subsequentes sobre a Constituição Federal. Se as Constituições Estaduais são extensamente baseadas na Constituição Federal, o padrão de emendamento observado nesses dois níveis seria similar? As Constituições Estaduais foram tão emendadas quanto a Federal? Caso se observe que tais Constituições são cópias diretas, o que explicaria eventual diferença de emendamento entre União e estados? E entre estados eles mesmos? 
O federalismo é um conceito de difícil definição e operacionalização. A sua redução às características de um ou outro modelo de federalismo incorre em um problema de reduzida capacidade de generalização. Dentro dessa perspectiva, o sistema brasileiro é objeto de controvérsias. Para alguns autores seria um modelo altamente restritivo, que devido a seu arranjo institucional incorreria em uma paralisia decisória (STEPAN, 1999) por agregar instituições que quando utilizadas em conjunto possuem efeitos desastrosos para a governabilidade (LIJPHART, 1999). Enquanto outros autores argumentam que o modelo brasileiro é mais complexo, e não basta observar simplesmente as instituições formais para que se compreenda de fato como o jogo político ocorre no país (ARRETCHE, 2001; RIKER, 1975; SOUZA, 2005). Não obstante, as instituições formais são relevantes para a configuração do jogo político e também podem auxiliar na compreensão e análise de mecanismos alternativos. Uma instituição formal estudada amplamente, tanto no Brasil quanto em outros países, é a Constituição. Para (LUTZ, 1994), por mais que as constituições não reflitam a realidade total do sistema político, são uma importante janela para a compreensão deste.

Uma Carta Constitucional, por mais que não reflita perfeitamente como se dá o cotidiano político de um país, as coalizões, conflitos, competições etc., pode servir como balizador dessas interações. Ademais, a compreensão dessa instituição formal pode auxiliar no desenvolvimento e compreensão de mecanismos não tão claros. No caso brasileiro, atenção constante é dada à Constituição Federal, especialmente a de 1988, uma vez que este é considerado o documento máximo de regulação. Uma característica já observada nesta Carta é sua extensão, com presença significativa de matérias de deliberação infraconstitucional. Como não cristaliza apenas princípios, mas também regras, direitos e ampla gama de políticas públicas, é por vezes chamada de Constituição Dirigente (ARANTES; COUTO, 2009; ARRETCHE, 2013a, 2013b; COUTO, 2005; SOUZA, 2005). Além de uma situação inicial que gerou uma constituição extensa, marcada por políticas públicas, o Brasil também apresenta relativa facilidade no emendamento desta, bem como um sistema de partilha de competências que favorece a União. Com isso, a distribuição de poder no estado federativo brasileiro merece atenção.

Outra instituição formal existente no Brasil são as constituições estaduais. Usualmente estas são relegadas a segundo plano, e há pouca literatura tratando do 
tema, bem como dificuldade de encontrar os dados necessários e atualizados. Argumenta-se que, por conta do regime de separação de competências, não restaria a estas constituições muito espaço para prever e endereçar legislação estadual, mas para sustentar tal argumento algum tipo de estudo é necessário. Ao levantarmos os dados de mudança constitucional verificamos que essa alegação não se verifica. As constituições estaduais estão em constante alteração no Brasil, e sequer encontramos homogeneidade no padrão de alteração entre os estados.

A própria dinâmica legislativa no nível estadual é pouco estudada. Usualmente argumenta-se que as assembleias legislativas são instituições marginalizadas do processo político, sem poder de decisão ou de agenda frente à força dos governadores nos estados. Estudos mais recentes indicam para uma dinâmica um pouco mais complexa, em que a força das assembleias pode ser vista quando analisados os projetos de lei e o processo de policymaking, tanto de forma agregada quanto caso a caso (SILVA, 2012, 2013; TOMIO; RICCI, 2012a, 2013b). Devido à falta de literatura acerca desse ponto, uma investigação acerca dos mecanismos de policymaking das assembleias se torna relevante. As emendas à Constituição Federal se tornaram mecanismo de governo pós-1988 no âmbito federal (ARANTES; COUTO, 2009; COUTO; ARANTES, 2006); dada a similaridade institucional entre os entes federativos - consequência do princípio da simetria - é possível que esse mecanismo se reproduza em âmbito estadual. De acordo com as regras de proposição e aprovação de emendas destacamos neste estudo dois atores que possivelmente fazem uso da alteração constitucional para fixar suas preferências intertemporalmente: os governadores e as próprias assembleias legislativas. $\mathrm{Na}$ próxima seção, apresentaremos os elementos teóricos que informaram nossa pesquisa sobre as constituições e o papel destes atores no processo de emendamento constitucional.

\subsection{Construção Teórica do Problema}

1.1.1. Constituição Federal e as Constituições Estaduais 
No Brasil o sistema de duas constituições foi inaugurado na proclamação da República. O primeiro fato marcante é que, assim como o sistema federativo, o modelo constitucional foi "às avessas". Ou seja, as constituições estaduais (CE) só surgiram após a promulgação da Constituição de 1891, o que cria um sistema de incentivos praticamente contrários aos encontrados no modelo estadunidense, cuja Constituição Federal (CF) surge posteriormente à existência das leis maiores regionais. Na ocasião da promulgação da Constituição de 1988 o fato se repete e as constituições estaduais só são promulgadas em 1989. Esses textos não só tomaram a Carta de 88 como norte, mas acabaram por se basear amplamente no próprio texto da CF, repetindo princípios e comumente transcrevendo diretamente trechos ou artigos inteiros da CF. Com isso as CEs promulgadas em 1989 possuem mais do que princípios em comum ${ }^{1}$, em decorrência disso é de se esperar que as CEs apresentem características semelhantes às observadas na CF. Assim, uma abordagem da Constituição Federal deve auxiliar no estudo das CEs.

A Carta de 1988 apresentou uma tendência à constitucionalização das mais variadas questões que no período eram consideradas importantes. Isso é explicado pela possibilidade de se precaver contra as incertezas decorrentes da alteração do regime político, por uma reação de descaso em relação às questões constitucionais propostas pelo regime anterior (SOUZA, 2005) e pelo próprio modelo de constituinte adotado. Tal tendência resultou em uma "constituição que regula não só os princípios, regras e direitos - individuais, coletivos e sociais - mas também um amplo leque de políticas públicas" (ibid. p.109).

Uma primeira análise do texto constitucional de 1988, realizada por Arantes e Couto (2009), revelou que cerca de $30,5 \%$ dos dispositivos presentes possuíam caráter de política pública. É de se esperar que uma constituição com tal característica congelasse o quadro de interesses e preferências vigentes na época, mas não foi o que ocorreu. Ao contrário, a constitucionalização de policies fez com que o "marco constitucional permanecesse sob intervenção frequente dos governos, cujas agendas governamentais ordinárias foram confundidas com agendas constituintes apenas

\footnotetext{
${ }_{1}^{1}$ A fruto de exemplo, na Constituição do Rio de Janeiro, cerca de $79,1 \%$ do texto do "Título VI - da Tributação e Orçamento" é cópia direta da Constituição Federal de 1988. As outras Constituições Estaduais também apresentam similaridade elevada, no entanto este é um conceito de difícil operacionalização em virtude da utilização de sinônimos, inversão da ordem do discurso e outras alterações textuais sem que alguma alteração real seja efetuada.
} 
porque tais governos foram obrigados a operar por meio de supermaiorias de 3/5 nas duas Casas Legislativas" (ibidem, p. 28).

Observando a dinâmica política podemos ver a existência de uma agenda constituinte, como se o processo de reconstitucionalização não houvesse terminado com a promulgação da constituição de 1988, já que os governos posteriores se viram praticamente obrigados a desenvolver parte de suas agendas normativas no plano constitucional (COUTO; ARANTES, 2006). Assim, a própria elevada constitucionalização de políticas públicas na Carta de 1988 é a hipótese básica que explica o elevado processo de emendamento constitucional no pós-88 (ARANTES; COUTO, 2009). Essa característica engendra um ciclo permanente: quanto maior o número de políticas públicas na situação inicial da constituição, mais ela obriga os governos a exercerem sua agenda em nível constitucional, ou seja, maior o processo de emendamento e assim, maior o número de políticas públicas constitucionalizadas, o que incita novamente a continuidade do governo em nível constitucional.

A presença de tais dispositivos de políticas públicas na carta de 1988 é explicada, por Couto e Arantes (2006), pelo formato da Assembleia Constituinte, baseado num modelo descentralizado, sem projeto-base, com negociações por sistema de log-rolling, o que favoreceu a introdução de dispositivos particularistas, ou seja, de dispositivos com características de políticas públicas. Assim, a própria constituição de 1988 gerou o processo de agenda constituinte permanente, já que "engessou formalmente a agenda governamental futura e era mesmo de se esperar, como de fato ocorreu, que boa parte desses dispositivos se tornasse futuramente alvo de tentativas de reforma" (ibid. p.45), sem falar na própria previsão de revisão da carta estabelecida para cinco anos após sua promulgação, o que demonstra novamente o caráter volátil da nova Constituição.

Vale reconhecer que alguma forma de alteração dos textos constitucionais é esperada. Segundo Lutz (1994), a operacionalização da soberania popular implica a necessidade de um processo formal de consenso público, mas devido à falibilidade humana este mesmo consenso deve estar sujeito a alterações sempre que necessário. Quando esse consenso se dá por meio de uma constituição, a diferenciação entre matérias constitucionais e legislação infraconstitucional implica 
que as constituições devem passar por maior deliberação e consequentemente maior dificuldade de alteração. Sendo assim, para o autor, um processo de alteração constitucional muito fácil não diferencia corretamente os níveis legais e viola a premissa do processo deliberativo, afetando diretamente a soberania popular. Enquanto um processo muito difícil viola a premissa da falibilidade humana e impede a também operacionalização da soberania popular, já que indivíduos em uma situação inicial acabarão por determinar as matérias de consenso popular dos períodos futuros sem que alterações possam ser realizadas. Então, assim como a Constituição Federal, as cartas estaduais admitem a possibilidade de revisão e alteração do texto. Mas tal alteração segue regras diferentes em cada país, e no caso de estados federativos, não há provisão central que determine uma regra única de alteração, cada estado pode determinar a sua regra. O que Lutz defende é que, tendo em vista um processo ideal de reforma das constituições, essa regra não deve estabelecer nem o método mais fácil nem o mais difícil de fazê-lo.

Nos estados brasileiros, o critério para aprovação de emendas é a votação, unicameral, em dois turnos, com maiorias que podem ser de dois terços ou três quintos. A capacidade de propor emendas às suas respectivas constituições é consideravelmente variada. As Assembleias Legislativas e os Governadores possuem tal capacidade em todos os estados, mas apenas em parte deles o papel das Câmaras Municipais e da iniciativa direta da população estão previstos. Esses critérios variam de requisitos como um quinto das Câmaras (Rio Grande do Sul) até três quintos (Tocantins), sendo que em quatro estados as Câmaras não detém tal poder. Quanto à iniciativa popular, são necessários de $0,5 \%$ (Pará) a 5\% (Amazonas), com 12 estados não prevendo a proposta de alteração pela via popular. Outro meio de proposta que merece atenção é, no Pará, pelo Tribunal de Justiça, após aprovação pela maioria dos Desembargadores. Com isso pode-se notar que as restrições impostas ao processo de emendamento constitucional nos estados são um tanto quanto uniformes se considerarmos os requisitos de aprovação das emendas, mas a proposição diverge consideravelmente entre eles. Os critérios de aprovação são semelhantes aos da União, que exige maiorias de no mínimo 3/5 em dois turnos nas duas casas congressuais. 
As regras de proposição e aprovação de emendas não dizem tudo sobre as chances de sua ocorrência. A constitucionalização de políticas públicas pode representar um grande incentivo ao permanente processo de alteração constitucional. Outro impacto associado a esse tipo de constitucionalização de políticas públicas é a modificação no próprio equilíbrio dos três poderes (Executivo, Legislativo e Judiciário). Em nível federal, Arantes e Couto (2009), ao observar o processo de emendamento de 1988 a 2009, notaram a elevação do papel do Judiciário na política, em especial na condução da política econômica, já que "todos os planos econômicos adotados desde [o governo] Sarney tiveram sua constitucionalidade questionada nos tribunais" (ibidem, p.30). Quanto ao nível estadual, Vianna, Burgos e Salles (2007) defendem que um dos atores que mais propõe Ações Diretas de Inconstitucionalidade (ADI) contra o legislativo estadual são os próprios governadores. Tais recursos do executivo, inúmeras vezes objetivam derrubar iniciativas do legislativo que atendem a interesses particularistas de corporações de serviço público. Assim essa tendência aumentará quanto maior for o conflito entre executivo e legislativo. Para os autores, a quantidade de ADI contra normas dos legislativos estaduais aponta não só para uma dinâmica do conflito federativo, mas também "para a existência de problemas na formação da vontade política local, seja porque o executivo não detém maioria nas assembleias estaduais, seja porque essas instâncias de poder, expostas a grupos de interesses particularistas, eventualmente produzem uma legislação casuística e sem escopo universalista" (ibid. p. 50).

O sistema federativo necessita também de um mecanismo de cooperação entre os entes, mais especificamente um arranjo de reciprocidade. Se o modelo federativo é considerado uma relação contratual no qual as diferentes partes detentoras de poder cumprem obrigações mútuas, faz pouco sentido chamar de federação aquele regime no qual o governo central pode obter tudo o que deseja dos governos locais simplesmente por atos administrativos. No federalismo, para algum "subconjunto das decisões ou atividades do [governo] central, torna-se necessário obter o consentimento ou a cooperação ativa das unidades subnacionais" (RODDEN, 2005, p.17). Nesse sentido, no sistema federativo deve ocorrer uma partilha nas esferas de atuação de cada ente. É na Constituição de 88 que essa divisão é estipulada por meio do regime de competências. 
Aos estados brasileiros é assegurada a competência residual, qual seja, é permitido aos estados legislar sobre tudo aquilo que não está reservado ao governo da União, e pequena parcela de competências exclusivas². À União é assegurada a maior parte das competências exclusivas, que devido ao detalhamento e extensão da Carta, estendem-se a uma grande variedade de temas. Assim, já na promulgação da CF a União cerceia as competências estaduais ao determinar para si ampla gama de exclusividades, mas existe ainda outro fator, as competências concorrenciais. Neste ponto os constituintes partiram do princípio de que os serviços públicos, em especial os sociais, deveriam ser elaborados em regime de cooperação entre os três níveis da federação, mas tal cooperação tende a não ocorrer por três fatores. Em primeiro lugar existe a diferença da própria capacidade de implementação das políticas, reflexo das desigualdades financeiras e técnicas; segundo a ausência de qualquer tipo de mecanismo institucionalizado que estimule ou assegure a cooperação, e por fim devido à própria orientação do STF, que de maneira autônoma defende a hierarquização dos entes neste quesito, isto é, quando houver alguma forma de disputa entre as deliberações, a legislação federal será priorizada (SOUZA, 2005), o que remove a característica concorrencial e assegura a primazia do governo federal nas disputas.

Um dos possíveis impactos desse regime de competências é um arranjo institucional no qual cada nível de governo tem o incentivo à inovação na legislação por duas vias. Uma delas é pelas competências residuais, uma vez que os governos locais são incentivados a iniciar legislação nas matérias ainda não estabelecidas pela União, enquanto esta, por sua vez, é incentivada a iniciar legislação nas matérias residuais com o objetivo de maior centralização. Nesse ponto, Costa (2007), afirma que dificilmente o governo federal renuncia ao direito de legislar sobre um assunto no qual tenha interesse, portanto existe tendência de centralização do processo legislativo nas competências residuais, precedido por inovação por parte dos estados. A outra é com relação às competências concorrentes existem "fortes incentivos para a inovação em políticas públicas na medida em que cada nível de governo tenta

\footnotetext{
${ }^{2}$ As competências exclusivas dos estados são segurança e zonas metropolitanas (ARRETCHE, 2013a).
} 
controlar a jurisdição de uma política antes que o outro o faça" (ARRETCHE, 2001, p. 27), mesmo que o Judiciário favoreça a União.

Sabendo que uma característica dessas cartas é a grande quantidade de políticas públicas elevadas a nível constitucional, o regime de competências acaba por incentivar a utilização da Constituição como instrumento de governo, consequentemente por meio do emendamento constitucional tanto federal quanto estadual. O que corrobora não só com a hipótese do efeito da constitucionalização de políticas públicas, mas também com o aumento da atuação do Judiciário, já que com maior inovação nas políticas públicas constitucionalizadas, esse poder ganha mais espaço de atuação.

Assim, segundo a abordagem de Rodden (2005) a federação brasileira não seria uma federação propriamente dita, uma vez que não só parece haver primazia da União em virtude do regime de competências, mas também não há um sistema de cooperação entre os diferentes entes em virtude do caráter altamente centralizador do federalismo brasileiro. Em sentido contrário, Souza (2004) afirma que é difícil descrever o sistema brasileiro como centralizador ou descentralizador, uma vez que é marcado por "federally centralized policies and by constraints on subnational freedom to introduce legislation, blocked also by judicial interpretation, with few constitutional powers allocated to the states" (ibid. p. 1). Contudo, os estados gozam de autonomia administrativa e capacidade de implementação de políticas, garantida também pela parcela de recursos que recebem devido ao arranjo dado pela constituição de 1988. Assim, por mais que não detenham toda a independência e capacidade constitucional da União, acabam por resguardar uma parcela significativa dos recursos e gastos públicos, sendo responsáveis por $43 \%$ da receita com tributação, $62 \%$ dos gastos com salário e $78 \%$ dos investimentos públicos.

Ao considerar a partilha de recursos na União também não há consenso quanto a seu caráter centralizador ou não, nem quanto aos seus impactos. Alguns autores argumentam que ao garantir autonomia de tributação e gasto aos governos locais, bem como maior autonomia decisória e de implementação de políticas, é de se esperar que os policy-makers tenham mais proximidade com os cidadãos, e com isso o provimento de bens-públicos será mais elevado do que em estados centralizados 
(OATES, 1999, 2005). De outro lado surge o argumento que arranjos nos quais essa autonomia é assegurada acarretarão não só em menor provimento de bens-públicos, mas também em assimetria no acesso a eles (RODDEN; ROSE-ACKERMAN, 1997)

O mesmo ocorre quanto à dimensão de centralização ou dispersão da capacidade decisória. Por um lado arranjos nos quais a formação de grupos de veto por minorias é excessivamente facilitada podem desencadear um quadro de paralisia decisória, e tal situação é agravada caso esse poder de obstrução seja incorporado na Constituição (STEPAN, 1999). Por outro, o arranjo que centralize em demasia o poder em um governo central pode desencadear não só em uma ditadura da maioria (LIJPHART, 1999), mas também em profunda ineficiência econômica, um governo predatório e possivelmente a monopolização do poder (WEINGAST, 2009, 2014).

Com isso Arretche (2013b) sugere que não há um arranjo institucional isento de riscos. Sempre haverá um trade off na partilha de poder nas federações que envolverá riscos e benefícios distintos em cada modelo de concentração ou dispersão do poder e autoridade do governo central. Stepan (1999), com o objetivo de aprofundar o estudo e a categorização dos sistemas federalistas, propõe classificar os estados federados segundo um continuum dos poderes de veto das minorias, isto é, da capacidade das minorias bloquearem iniciativas de interesse das maiorias (ARRETCHE, 2013b). As demos-constraining seriam aquelas nas quais as minorias possuem amplas capacidades de constranger o demos, os interesses das maiorias, as demos-enabling são aquelas em que as minorias possuem poderes reduzidos. $\mathrm{Na}$ teoria de Stepan (1999) uma das dimensões que permite avaliar a característica de concentração ou dispersão do poder é de ordem constitucional, mais especificamente o grau no qual a Constituição confere poder de elaborar políticas às unidades da federação. Essa variável possui três elementos, o volume de questões legislativas na Constituição, a partilha de poderes entre os entes federativos e o poder de legislação residual.

Arranjos constitucionais muito parcimoniosos ou muito restritivos podem levar a situações que prejudicam a consolidação democrática. A constitucionalização de matérias significa por si mesma a formação de pontos de veto, mas não a de atores de veto, já que "a vedação a que determinadas decisões sejam implementadas não 
decorre diretamente da ação de qualquer ator político, mas sim da interdição constitucional formal a que determinadas coisas sejam feitas" (ARANTES; COUTO, 2009, p.20). Assim, as restrições previstas em uma constituição deveriam em primeiro lugar garantir que não existam meios de que uma maioria possa acabar com o próprio jogo democrático. Tal questão pode ser vista sob duas óticas. Em uma delas, a constituição é interpretada como aquela que fixa os limites de ação das maiorias e as impede de acabar com o jogo ou decidir unilateralmente tanto no momento quanto no futuro; na outra, a Carta é vista sob a perspectiva contrária, isto é, um texto que, elaborado por uma maioria, deixa aberta às gerações futuras a possibilidade de escolha independente sobre qualquer assunto, não sendo assim restringida por uma maioria anterior (COUTO, 2005)

Retomando a abordagem de Stepan (1999), para o autor o arranjo institucional brasileiro seria um caso extremo de demos-constraining, que invariavelmente levaria à paralisia decisória. Isso por conta da representação das unidades constituintes no Congresso. Já que de um lado existe a representação destas no Senado, de outro, devido à desproporcionalidade da Câmara dos Deputados, associada com o controle dos governadores sobre os recursos necessários à eleição dos membros, levariam a esse arranjo institucional no qual os líderes regionais teriam amplos poderes de veto, reduzindo assim as chances de reformas propostas pela maioria ou mesmo pelo governo da União. Já Arretche (2013b) argumenta que tais previsões feitas pelo autor não se concretizaram. O país passou por amplas reformas, sendo muitas delas restritivas aos poderes e autonomia decisória dos governos locais, o que indica o elemento demos-enabling do arranjo institucional brasileiro. Um dos fatores institucionais levantados pela autora é o fato da Constituição de 88 conferir amplos poderes legislativos à União, bem como ampla gama de competências exclusivas e reduzida capacidade de veto aos governos subnacionais. Outra característica levantada por Arretche (2013a) é o emendamento à constituição ser considerado relativamente fácil, já que não é necessário referendo ou aprovação das unidades subnacionais, o que remove mais uma possibilidade de veto dos estados. Assim, para a autora a Constituição Brasileira de 1988 não limitou os poderes da União, ao contrário, garantiu que o governo federal possuísse primazia sobre diversas matérias. 


\subsubsection{Relação Executivo-Legislativo nos estados}

A abordagem de Stepan (1999), embora contestada por Arretche (2013a, 2013b), tem como elemento fundamental da explicação sobre a paralisia decisória o controle dos governadores sobre os recursos estaduais. Tal controle garantiria aos governadores influência sobre a eleição de deputados, e por meio destes os governadores assegurariam poder de decisão na Câmara dos Deputados. Também nessa linha argumentativa, qual seja, a da força desproporcional dos governadores, Abrúcio (1988) revisa o poder dos governadores e remonta sua origem na transição democrática e a forma pelo qual asseguraram significativos poderes e recursos para o executivo estadual. Em virtude da preponderância do executivo na condução da política em nível estadual, isto é, o controle do executivo não só sobre o processo decisório, mas também sobre as assembleias legislativas, Abrúcio cunha o termo ultrapresidencialismo estadual. $\mathrm{O}$ controle do executivo sobre o legislativo se daria, entre outros, pela reduzida participação dos legisladores estaduais no processo decisório e pela formação da coalizão governante.

Segundo essa abordagem, o suposto poder exacerbado dos governadores possuiria como origem seis fatores. Os poderes financeiros; o sistema eleitoral; a ausência de contrapesos regionais; a fragilidade institucional das assembleias legislativas; a baixa visibilidade política; e a neutralização dos órgãos fiscalizadores. Assim o autor levanta uma questão que distingue a dinâmica política estadual da nacional, já que, se no plano nacional existe um problema de formação de maioria política nos parlamentos (Figueiredo e Limongi, 1998), no plano estadual foi observado o fenômeno contrário, qual seja a preponderância do executivo sobre 0 legislativo. Essa supremacia se daria logo no começo do governo por meio da formação de amplas maiorias nas assembleias legislativas. Assim os legislativos estaduais seriam fracos e marginalizados, não desempenhando nenhuma função ativa ou real na condução das políticas. Para Mezey (1983) o poder legislativo como um todo, isto é, tanto o poder legislativo nacional quanto o subnacional, seriam instituições que no máximo desempenham papel marginal exclusivamente sobre o processo de law-making. 
Em contrapartida ao argumento do ultrapresidencialismo, Tomio e Ricci (2012a; 2012b) encontram certa equivalência entre deputados e governadores no controle da agenda legislativa infraconstitucional em nível estadual ${ }^{3}$. Os autores abordam a questão de três formas. Pela produção legislativa (em quantidade), pelo número de vetos e pela natureza das propostas. Segundo os autores os parlamentos estaduais não devem ser considerados miniaturas do Congresso e nem atores marginais, já que possuem agenda política própria e pauta decisória específica.

A relação executivo/legislativo em nível federal diverge significativamente do nível estadual. Segundo Tomio e Ricci (2012a) nas assembleias estaduais a taxa de dominância do executivo na produção legal é de, em média, 27,3\% (contra 83,3\% na Câmara dos Deputados), o sucesso do executivo é $87,6 \%$ ( $75,1 \%$ no caso da União), e o sucesso do legislativo é de $43,3 \%$ (menor que $1 \%$ na Câmara). Os vetos se distribuem de maneira assistemática entre os estados. Não se observa constância nem em termos de quantidade de vetos nem na forma do veto. No entanto pode-se generalizar no sentido de afirmar que os governadores se utilizam mais do veto total quando lidam com propostas oriundas das assembleias $(88,3 \%$ dos vetos são absolutos). O efeito do veto absoluto é a recusa total do pacote proposto pela assembleia, com isso o executivo sinaliza um comportamento de não negociação e conflito com o legislativo (CAREY; SHUGART, 1998). Os dados de vetos derrubados indicam que cerca de $35 \%$ dos vetos dos governadores (tanto nas propostas do executivo quando do legislativo) são revistos pelas assembleias.

A força dos legislativos e executivos estaduais deve ser também analisada sob a luz da natureza das propostas. Assim os autores classificaram as propostas em três tipos, estaduais, que são as mais abrangentes, municipais que se concentram sobre questões dos municípios, e simbólicas, que podem ser consideradas insignificantes uma vez que não causam nenhum impacto direto (homenagens, nomeação de ruas e etc.). Os projetos de lei do executivo são principalmente de cunho estadual $(71,3 \%)$, os do legislativo também tem sua maior proporção nas propostas estaduais, mas em menor dimensão (53,8\%). Já a dimensão municipal representa apenas $32,7 \%$ das propostas do legislativo, o que indica, segundo os autores, um

\footnotetext{
${ }^{3}$ Estudo realizado em 12 assembleias para o período de 1999 a 2006.
} 
contra-argumento na ideia de que os legisladores estaduais estão mais envolvidos em atividades locais ou particularistas. No entanto a taxa de sucesso para as propostas estaduais dos legislativos é reduzida (19,9\%), em contrapartida, a dos executivos é significativamente alta (88,3\%), mas dada a diferença em termos absolutos de propostas surge certa equivalência dos poderes, por mais que os legislativos tenham menor sucesso, realizam mais propostas, gerando um resultado final similar (TOMIO; RICCI, 2012b). Outros trabalhos sobre a produção legislativa estadual e a relação executivo/legislativo se concentram em análises de casos específicos, considerando recortes temporais e assembleias específicas (NUNES, 2009; SANDES-FREITAS; MASSONETTO, 2012; SANTOS, 2001; SILVA, 2012, 2013)

Devido à divisão de competências expressa na CF, a possibilidade de introduzir legislação por parte dos estados é reduzida. Além disso, os poucos temas que os estados têm capacidade de deliberar são em sua maioria controlados pelo executivo. A CF também determina que é competência do governador deliberar sobre o regime de serviço público, questões tributárias e orçamentárias, estrutura administrativa, entre outros. Sendo assim, para legislativos estaduais as competências são ainda mais reduzidas. As análises destacadas se focaram sobre toda a produção legislativa estadual. O nosso objetivo é limitá-la à produção normativa constitucional e verificar de que forma governadores e assembleias operam nesse nível distinto da legislação infraconstitucional devido ao quórum necessário a aprovação ser mais elevado e por sua rigidez, que torna sua alteração ou remoção um processo mais custoso. Outro ponto que merece destaque é que não há possibilidade de veto do executivo sobre as emendas constitucionais, o que pode indicar uma arena de atuação das assembleias independente dos executivos regionais. Ademais, deve-se considerar que a partilha de competências se dá sobre legislação infraconstitucional, o que pode abrir a possibilidade do legislativo usurpar matérias de competência do executivo por meio da constituição.

O arranjo institucional adotado com a Constituição de 1988 favoreceu iniciativas inovadoras por parte dos legisladores, tanto estaduais quanto federais. $O$ regime de competências garantiu à União primazia em diversas matérias, no entanto a legislação estadual não pode ser desconsiderada. Análises do perfil de legislação em nível estadual demonstram que existe considerável equilíbrio entre o poder dos 
governadores e assembleias, contrariando a tese do ultrapresidencialismo estadual. No entanto, tais análises se focaram na legislação infraconstitucional. Pouco ou nenhum estudo foi feito acerca das Constituições estaduais, seu perfil de emendamento e seu conteúdo. Parte disso devido ao argumento corrente de que as constituições estaduais não importam já que são "mera repetição dos mandamentos federais" (SOUZA, 2005, p. 111). Mas nem mesmo esta abordagem foi submetida a investigação detalhada.

\subsection{Primeiras tentativas de explicação do emendamento}

As constituições estaduais se basearam significativamente na Constituição Federal, seja em termos de princípios ou mesmo semelhança textual, o que sugere igualmente que tenham tamanhos muito próximos. Em consequência deste espelhamento também é de se esperar uma estrutura semelhante à Constituição Federal e, por conseguinte, uma elevada constitucionalização de políticas públicas também no plano dos estados. No entanto, observamos variabilidade na extensão das Constituições Promulgadas, assim mesmo que sob o princípio da simetria e com partes transcritas da Constituição Federal, a extensão das Constituições Estaduais é variada. Em paralelo também observamos que há heterogeneidade no emendamento, mesmo que as regras de aprovação sejam virtualmente iguais entre os estados. Por um lado esta variabilidade no emendamento pode ser resultado da própria variabilidade na extensão das Constituições Estaduais, no entanto acreditamos que há outros fatores associados ao emendamento.

O emendamento como função do tamanho inicial das constituições e da rigidez é proposto por Lutz (1994), que adota como variável dependente a taxa de emendamento constitucional. Ao explicar sua dinâmica o autor tem como objetivo avaliar de que forma as constituições mudam ao longo do tempo bem como a longevidade delas. Para o caso dos estados brasileiros a longevidade pós-88 não é relevante até o momento, uma vez que todas foram promulgadas em intervalo muito curto de tempo e ainda estão em vigência. Para captar o emendamento o autor se utiliza da taxa de emendamento constitucional, que é calculada dividindo-se o número total de emendas pela duração (em anos) da Carta. Para o autor uma constituição 
duradoura deve apresentar alguma taxa constante, refletindo com isso as mudanças graduais no sistema político, reconhecimento de erros, experiência política, e subsequente adequação da Constituição. Com isso o autor assume que deve existir uma taxa ótima de emendamento que maximiza a duração das Cartas.

A partir de suas premissas Lutz (1994) propõe que quanto maior a extensão de uma Constituição (medida em palavras), maior a taxa de emendamento. Já que quanto mais extensa é de se esperar que integre mais temas passíveis ou que necessitem de alteração, então a causalidade assumida é que quanto maior o tamanho da constituição no ato de sua promulgação, maior será a taxa de emendamento encontrada. Outra hipótese levantada é que quanto mais rígido o processo de alteração constitucional, menor a taxa de emendamento. Com isso Lutz (1994) constrói um índice de rigidez constitucional. Esse índice, que visa medir o quão difícil é emendar uma constituição, é composto por diversas categorias e características do emendamento (necessidade de maioria absoluta, maioria qualificada, votação em dois turnos, referendo popular, no total são 68 critérios). Para a construção de fato do índice, o autor levantou os critérios para emendar as constituições nos estados dos EUA bem como a taxa de sucesso do emendamento nestes estados e finalmente normaliza tomando como base o método mais fácil encontrado nos EUA. A partir de suas duas variáveis desenvolve um modelo no qual a taxa de emendamento é variável dependente, explicada pelo tamanho da constituição (medido em palavras) e pelo índice de rigidez de cada local. Com isso o autor chega a resultados significativos estatisticamente, especialmente com relação ao tamanho das constituições.

Replicar a análise de Lutz (1994) para o caso dos estados brasileiros incorre em dois problemas. Além de o índice de rigidez ser praticamente invariável no caso dos estados brasileiros, já que as regras de emendamento praticamente são praticamente as mesmas em todos eles, o índice de rigidez foi construído apenas com base nas características dos estados americanos, que não apresentam toda a multiplicidade de possibilidades e barreiras ao emendamento. Com isso a valoração do índice de rigidez para qualquer método que não seja encontrado naqueles estados (por exemplo, legislaturas unicamerais, como é o caso dos estados brasileiros) é, segundo Lorenz (2005) fictícia e construída a mão, o que invalida boa parte do índice do autor. Noronha (2014) argumenta que surge um problema de tautologia no 
embasamento do índice, uma vez que o modelo de Lutz tem como variável dependente a taxa de emendamento e como variável explicativa o índice de rigidez, que por sua vez é função de taxas de emendamento encontradas (já que se utiliza destas para encontrar a taxa de sucesso em cada estado). Com isso o modelo utilizado por Lutz (1994) incorre na falácia de utilizar a taxa de emendamento para calcular o índice que será utilizado para prever a própria taxa de emendamento. Ademais diversos autores encontraram erros de estimação nos modelos de Lutz (1994), alguns deles foram erros nos cálculos das taxas de emendamento, Lorenz (2005) encontra discrepâncias nas taxas de emendamento da Alemanha, França, Irlanda e Nova Zelândia; Noronha (2014) na Índia; e Elkins, Ginsburg e Melton (2009) em 9 dos 32 países levantados por Lutz (1994).

\subsection{Hipóteses Relevantes.}

Nosso objetivo é uma primeira análise exploratória do constitucionalismo estadual brasileiro. Como primeiro passo desenvolvemos uma análise descritiva das Constituições Estaduais promulgadas após 1989 e das emendas aprovadas entre 1989 e 2014. Com base nestas descrições prosseguimos a tentar explicar parte da variabilidade no emendamento estadual. No entanto, não propomos o desenvolvimento de teorias gerais acerca do emendamento ou mesmo de modelos complexos que captem todos os fenômenos causais, mas sim uma exploração de possíveis efeitos, encontrados na literatura ou não, que se relacionam com o emendamento a fim de explicar parte da variabilidade. Para tanto desenvolvemos sete hipóteses, agrupadas em três conjuntos, que visam explorar relações entre 0 emendamento estadual e outras variáveis que consideramos relevantes.

O primeiro conjunto de hipóteses, que denominamos de hipóteses contextuais, aborda a relação entre o emendamento e variáveis estruturais, em especial econômicas. A tentativa de correlacionar a alteração constitucional com variáveis deste tipo é frequentemente encontrada na literatura de mudança constitucional, todavia a causalidade ou mesmo relevância do fenômeno não aparenta consenso (ELKINS; GINSBURG; MELTON, 2009; MONTENEGRO, 1995; 
NEGRETTO, 2012; TSEBELIS; NARDI, 2014). Em virtude da falta de uma teoria geral acerca do emendamento e sua relação com economia e desenvolvimento abordamos duas hipóteses, de caráter exploratório, a fim de verificar a possibilidade de associação entre essas dimensões. São elas:

H1: Emendamento Constitucional e desenvolvimento econômico variam em conjunto.

H2: Emendamento Constitucional é mais intenso em sociedades mais heterogêneas.

Para abordar a primeira hipótese utilizamos três formas de instrumentalizar o desenvolvimento econômico: o PIB, o PIB per capita e o IDH. Como não encontramos consenso acerca das possíveis relações entre o emendamento e a economia, optamos por hipóteses não direcionais que basicamente avaliam se há alguma associação observável. Já a segunda hipótese se baseia no argumento de que sociedades mais fragmentadas, seja esta econômica, social ou religiosa, apresentam constituições mais extensas e maior alteração Constitucional (GINSBURG, 2010; VOIGT, 2009). No entanto utilizamos apenas uma medida de fragmentação econômica, o índice de GINI. Este primeiro conjunto de hipóteses visa explorar a possibilidade de associação entre o emendamento constitucional e variáveis de caráter macroeconômico.

Nosso segundo conjunto de hipóteses, as hipóteses institucionais, exploram a relação entre o emendamento e instituições políticas predeterminadas. Este conjunto é o que encontra maior diálogo com a literatura de alteração constitucional.

Os primeiros modelos de emendamento constitucional partem do pressuposto de que quanto maior o texto constitucional mais este será emendando. A intuição por trás dessa premissa é que textos constitucionais muito extensos acabarão por constitucionalizar uma série de matérias. E com isso ensejarão maior emendamento. Essa abordagem foi tratada extensamente por Lutz (1994). Em seu modelo a taxa de emendamento é tomada como variável dependente enquanto o tamanho da constituição (medido em palavras) e um índice de rigidez são as variáveis independentes. Seguindo nessa linha Anckar e Karvonen (2002) defendem um índice de rigidez mais elaborado, que integra mais variáveis institucionais (como princípio 
majoritário ou consensual), mas defendem a própria rigidez como variável dependente. Por fim, Lorenz (2005) complementa esse tipo de abordagem ao reestruturar o índice de rigidez de Lutz (1994). Esse tipo de abordagem apresenta dois problemas, primeiro é a consideração do tamanho das constituições apenas em termos de palavras, deixando assim de explorar outras características inerentes a ela, e segundo é o índice de rigidez utilizado pelos autores. O índice de Lutz (1994) apresenta tautologias que o invalidam, já o índice de Lorenz (2005) possui problemas metodológicos levantados pela própria autora, que ao testar empiricamente suas hipóteses não encontra resultados significativos e afirma que isso ocorre provavelmente pela superestimação da rigidez constitucional. Independente dos problemas internos a essas metodologias, as hipóteses levantadas por esses autores não auxiliam muito a compreensão dos determinantes do emendamento no caso dos estados brasileiros, já que um fator marcante dessas constituições é a similaridade nas regras de aprovação e proposição de emendas, bem como das instituições políticas que as circundam. Com isso não se distinguem suficientemente para que a rigidez constitucional seja variável relevante que explique a diferença de emendamento entre os estados.

Nesse sentido, no caso dos estados brasileiros a rigidez constitucional não acrescenta informação ao ser utilizada como variável explicativa, já que é praticamente constante. Assim, com base no modelo de Lutz (1994), a variabilidade no emendamento estadual seria explicada apenas pela variabilidade no tamanho das Constituições. No entanto acreditamos que apenas esta variável é insuficiente, portanto esperamos que outras variáveis, omitidas no modelo do autor, também afetem essa dinâmica. Um possível determinante na taxa de emendamento das constituições é a hipótese levantada por Couto e Arantes (2006), qual seja, a quantidade de políticas públicas elevadas ao marco constitucional na Carta inicial ensejaria uma dinâmica de governo em nível constitucional e por conseguinte elevado emendamento. Temos então as seguintes hipóteses baseadas na extensão constitucional:

H3: Constituições mais extensas estão associadas com maior emendamento.

H4: Constituições com maior quantidade de políticas públicas apresentam emendamento mais elevado. 
A fim de abordar a primeira hipótese medimos a extensão das constituições estaduais bem como seu emendamento. Em virtude da variedade de formas de medir a extensão constitucional optamos por três unidades diferentes, duas mais frequentes na literatura, a quantidade de artigos e a quantidade de palavras, e a última, quantidade de dispositivos, que acreditamos ser mais adequada. A segunda hipótese pode ser considerada um desdobramento da primeira, tendo em vista que as medidas de extensão das constituições visam captar provisões específicas, ou de forma geral, políticas públicas constitucionalizadas. No entanto acreditamos que a quantidade de palavras ou artigos não é adequada para captar a quantidade de políticas públicas constitucionalizadas, então esta hipótese tem relação direta com a quantidade de dispositivos e o argumento de Couto e Arantes (2006). Mas o problema de testá-la para os estados brasileiros é exatamente o tamanho das constituições, já que a análise de todos os dispositivos torna-se tarefa árdua. Então como aproximação da constitucionalização de políticas públicas nas Constituições estaduais utilizamos a frequência de políticas públicas na Constituição Federal. Isso porque as CEs foram amplamente baseadas nos princípios contidos na CF e apresentam elevada frequência de transcrições diretas, então partimos do pressuposto que as constituições estaduais apresentarão número de políticas públicas próximo daquele encontrado na Carta de 88.

Por consequência dessa semelhança entre os textos estaduais e Federal bem como pela hierarquia constitucional estabelecida seja pelo regime de competências, pela organização federativa ou pela interpretação do judiciário, acreditamos que o emendamento estadual pode ser influenciado em grande medida pelo próprio emendamento federal. Sendo assim o emendamento estadual em um determinado período pode ser incentivado, positivamente, pelo emendamento federal em um período anterior. Por exemplo as constituições estaduais são alteradas a fim de se adaptar à mudanças introduzidas na Constituição Federal. Então temos a seguinte hipótese:

H5: Emendamentos federais em um ano ensejam emendamento estadual nos anos seguintes.

A fim de testar esta hipótese consideramos o emendamento anual, muito embora qualquer outro intervalo de tempo poderia ter sido escolhido. A abordagem 
sistemática dessa hipótese requer o desenvolvimento de um modelo complexo que capta a característica dinâmica do emendamento tanto federal quanto estadual e relaciona o emendamento estadual com emendamentos federais passados bem como emendamentos estaduais passados. No entanto o desenvolvimento de um modelo dessa complexidade está fora de nosso escopo, então optamos por uma abordagem mais simples em que defasamos o emendamento estadual em um ano e o comparamos com o emendamento federal, ou seja, pareamos o emendamento observado nos estados com o emendamento observado no ano anterior na União.

Finalmente o último conjunto de hipóteses é o que chamamos de hipóteses políticas. Neste exploramos a relação entre resultados do jogo político cotidiano com o emendamento constitucional nas legislaturas. Já que um possível fator capaz de alterar o emendamento, e explicar a heterogeneidade encontrada, é a dinâmica político-partidária das assembleias em cada legislatura e o papel do executivo na condução de políticas estaduais. Se levarmos em consideração que o emendamento às constituições estaduais possui origens semelhantes ao federal, qual seja, a utilização da constituição e emendamento como instrumento de governo, temos que as coalizões políticas devem alterar significativamente o resultado, bem como a força dos governadores. Portanto levantamos as seguintes hipóteses:

H6: A força política dos governadores está associada com o emendamento constitucional.

Utilizamos três variáveis como indicadores da força política, a porcentagem de votos obtidos pelo governador eleito, se foi eleito em primeiro ou segundo turno e o tamanho da coalizão governista. A interação entre as duas primeiras variáveis opera como indicador da força eleitoral do governador, já a segunda aponta para sua influência perante a assembleia legislativa. A fim de medir o tamanho da coalizão governista das assembleias, utilizamos a proporção de deputados estaduais eleitos pelos partidos que integram a coligação do governador eleito. Sabemos que as coligações eleitorais não são indicador adequado de coalizão, no entanto nosso esforço de medir o tamanho das coalizões por outros métodos foi infrutífero.

Além da força política dos governadores exploramos também a hipótese de que sistemas políticos mais fragmentados estão associados a menor emendamento. 
Esta advém do argumento de Negretto (2012) que sistemas políticos mais fragmentados apresentam menor emendamento quanto maior a rigidez. Mas, como a rigidez é constante, esperamos então que maior fragmentação será observada em paralelo com menor emendamento, já que a fragmentação possivelmente eleva os custos de aprovação das emendas constitucionais. Assim temos nossa última hipótese:

H7: Maior fragmentação partidária será observada em conjunto com menor emendamento.

A fim de medir a fragmentação política utilizamos dois indicadores. O Número Efetivo de Partidos (NEP), de Laakso e Taagepera (1979) e uma variação deste que chamamos de Número Efetivo de Coligações (NEC), que visa medir a fragmentação das alianças políticas no momento das eleições.

Assim nossa análise tem o objetivo de explorar o constitucionalismo estadual brasileiro. A identificação de fatores causais ou desenvolvimento de teorias e modelos complexos que expliquem os determinantes do emendamento representa uma ambição da qual o presente estudo é apenas um primeiro passo. Para que uma análise de tipo causal ou a formulação de teorias sejam realizadas, precisamos antes conhecer o cenário constitucional nos estados brasileiros. Assim, no capítulo I iniciamos uma análise descritiva das Constituições Estaduais em paralelo com a Constituição Federal, já que esta é frequentemente estudada e pode auxiliar a compreensão do constitucionalismo estadual. Neste primeiro capítulo também abordamos uma questão importante na literatura constitucional que são as formas de medir a extensão dos textos, e a fim de compará-las utilizamos três unidades de medida, a quantidade de artigos, de palavras e de dispositivos. As duas primeiras são frequentemente encontradas na literatura enquanto que a terceira foi desenvolvida por Couto e Arantes (2002).

No segundo desenvolvemos esforço semelhante mas de descrição do perfil de emendamento constitucional nos estados, também traçando paralelos com o emendamento federal. E por fim, no terceiro capítulo, abordamos de forma mais aprofundada e apresentamos alguns testes para as sete hipóteses apresentadas. 


\section{Análise Descritiva das Constituições Estaduais}

\subsection{Promulgação das Constituições Estaduais}

A Constituição Federal, promulgada em 05 de Outubro de 1988, determina no Art. $25^{4}$ que cada estado brasileiro deve elaborar sua Constituição, obedecendo aos princípios explicitados na Constituição Federal. O Ato das Disposições Constitucionais Transitórias definiu o prazo máximo de um ano a partir da data de promulgação desta, ou seja, os estados teriam até o dia 05 de Outubro de 1989 para promulgarem suas cartas. Tal providência é expressa no "Art. 11. ${ }^{5}$ Cada Assembleia Legislativa, com poderes constituintes, elaborará a Constituição do Estado, no prazo de um ano, contado da promulgação da Constituição Federal, obedecidos os princípios desta." (BRASIL, Constituição de 1988). Com isso a Constituição de 88 garante direitos constituintes a cada um dos estados brasileiros, mesmo que a obediência aos princípios daquela deva ser observada. A Tabela 2.1 contém as datas de promulgação das Constituições Estaduais (CE) e Lei Orgânica do Distrito Federal ${ }^{6}$.

\footnotetext{
4 "Art. 25. Os Estados organizam-se e regem-se pelas Constituições e leis que adotarem, observados os princípios desta Constituição." (Brasil, Constituição de 1988)

5 Tal artigo também conta com o seguinte dispositivo: "Parágrafo único. Promulgada a Constituição do Estado, caberá à Câmara Municipal, no prazo de seis meses, votar a Lei Orgânica respectiva, em dois turnos de discussão e votação, respeitado o disposto na Constituição Federal e na Constituição Estadual.". Determina então a forma como as Câmaras Municipais procederão com suas respectivas Leis Orgânicas, bem como deixa clara a hierarquia e princípio da simetria constitucional entre os entes federativos.

${ }^{6}$ Doravante não faremos distinção entre a Lei Orgânica do Distrito Federal e as Constituições Estaduais, ambos serão tratados como normas constitucionais equivalentes.
} 
Tabela 2.1 - Data de Promulgação das Constituições Estaduais

\begin{tabular}{cc}
\hline UF & Data \\
\hline AC & $03 / 10 / 1989$ \\
AL & $05 / 10 / 1989$ \\
AM & $05 / 10 / 1989$ \\
AP & $20 / 12 / 1991$ \\
BA & $05 / 10 / 1989$ \\
CE & $05 / 10 / 1989$ \\
DF & $08 / 06 / 1993$ \\
ES & $05 / 10 / 1989$ \\
GO & $05 / 10 / 1989$ \\
MA & $05 / 10 / 1989$ \\
MG & $21 / 09 / 1989$ \\
MS & $05 / 10 / 1989$ \\
MT & $05 / 10 / 1989$ \\
PA & $05 / 10 / 1989$ \\
PB & $05 / 10 / 1989$ \\
PE & $05 / 10 / 1989$ \\
PI & $05 / 10 / 1989$ \\
PR & $05 / 10 / 1989$ \\
RJ & $05 / 10 / 1989$ \\
RN & $03 / 10 / 1989$ \\
RO & $28 / 09 / 1989$ \\
RR & $31 / 12 / 1991$ \\
RS & $03 / 10 / 1989$ \\
SC & $05 / 10 / 1989$ \\
SE & $05 / 10 / 1989$ \\
SP & $05 / 10 / 1989$ \\
TO & $05 / 10 / 1989$ \\
\hline
\end{tabular}

O primeiro estado a promulgar sua Constituição foi o estado de Minas Gerais, no dia 21 de Setembro de 1989, enquanto a maioria das unidades federativas promulgariam suas constituições no prazo máximo estabelecido pelo Art.11 do Ato das Disposições Constitucionais Transitórias da Constituição Federal. No total 18 Assembleias Legislativas se utilizaram do prazo máximo de 05 de Outubro de 1989. Considerando a primeira constituição promulgada e essas últimas temos uma diferença de apenas 14 dias. No entanto, houve três casos excepcionais que ultrapassaram a data limite: Amapá, Distrito Federal e Roraima. O primeiro e o último promulgaram suas constituições apenas em Dezembro de 1991. Foi com a 
promulgação da Constituição de 1988 que deixaram de constituir Territórios Federais ${ }^{7}$ e elevados a status de estado da República Federativa. O primeiro Governador e a primeira legislatura da Assembleia Legislativa tomaram posse apenas em 01 de Janeiro de 1991, e foi a partir desta data que o prazo de um ano para a elaboração constitucional pela Assembleia passou a contar. O Distrito Federal promulgou sua Lei Orgânica em meados de 1993 e não encontramos informações pertinentes acerca desta diferença.

A Constituição de 88 determina um prazo de um ano para a promulgação das Constituições Estaduais então a elaboração desses textos deveria ser realizada em prazo reduzido. Se considerarmos que o tempo de elaboração de uma Carta constitucional corresponde à duração da Assembleia Constituinte, isto é, o número de dias corridos entre a instauração da Constituinte e finalização dos trabalhos, então não há informações suficientes para precisar a duração da AEC de cada estado, já que encontramos a data de instauração da Constituinte de apenas nove estados ${ }^{8} \mathrm{e}$ as datas de encerramento informadas coincidem com a data de promulgação das Constituições Estaduais. Mas dentre o prazo determinado pela Constituição de 1988 as Constituintes, e portanto a elaboração das Cartas, teriam duração máxima de $365^{9}$, em contrapartida a Constituição Federal de 1988 foi elaborada em 579 dias ${ }^{10}$ corridos.

\subsection{Estrutura Constitucional}

A Constituição Federal de 88 e as Constituições estaduais são divididas, estruturalmente, em preâmbulo, texto principal e Ato das Disposições Constitucionais Transitórias (ADCT). O preâmbulo é parte inicial do texto, contém enunciação dos princípios e valores que norteiam o texto constitucional. Segundo interpretação ${ }^{11}$ do

\footnotetext{
7 Como disposto no "Art. 14. Os Territórios Federais de Roraima e do Amapá são transformados em Estados Federados, mantidos seus atuais limites geográficos.

$\S 1^{\circ}$ A instalação dos Estados dar-se-á com a posse dos governadores eleitos em 1990." (BRASIL, 1988)

${ }^{8}$ São eles: AP; GO; MG; PI; RO; RS; SE; SP; TO.

${ }^{9}$ Assumindo a possibilidade, não crível, de que fossem instauradas um dia após da promulgação da Constituição de 1988.

10 Tal data refere-se ao tempo de elaboração da Constituição, adotando como ponto de início a instalação da Assembleia Nacional Constituinte e como ponto final a data de encerramento dos trabalhos da constituinte. (02/02/1987 - 02/09/1988)

${ }_{11}$ Ver ADI n.2076/AC.
} 
Supremo Tribunal Federal o preâmbulo não cria direitos e deveres, não tem força normativa e portanto não contém relevância jurídica, além de não ser necessária sua existência ou repetição nas Constituições Estaduais.

O texto principal - também chamado de Disposições Permanentes, Corpo Dogmático, corpo principal, entre outros - consiste na parte normativa das Constituições, é composto pelas normas (artigos) propriamente ditas e será foco de nossa análise. Por fim temos o Ato das Disposições Constitucionais Transitórias. A função do ADCT é auxiliar a transição entre os regimes por meio da adoção de regras temporárias, transitórias, que se tornariam efêmeras após o tempo transcorrido. $\mathrm{O}$ $A D C T$ possui estrutura diferente do corpo principal, já que conta com numeração própria, os temas não são organizados em seções, capítulos ou títulos e contém diversas normas de aplicabilidade temporária. Por interpretação do STF ${ }^{12}$, o ADCT possui o mesmo status jurídico que as normas do corpo principal, não há hierarquia quanto à eficácia ou prevalência das normas constantes no ADCT quando comparadas com as do corpo principal, "[...] todas essas cláusulas normativas, inclusive aquelas de índole transitória, ostentam grau idêntico de eficácia e de autoridade jurídicas" (Brasil. STF, 1995). O texto constitucional com relevância jurídica é composto tanto pelo corpo principal quanto pelo ADCT, e mesmo as normas transitórias cujos efeitos se exaurem com o tempo possuem hierarquia jurídica idêntica às demais. A análise considera ambos trechos das Constituições Estaduais como componentes das Cartas, quando nos referirmos à constituição completa ou total.

A estrutura organizacional do Texto Constitucional pode auxiliar a seleção e compreensão das variáveis. Pelo padrão de redação jurídica no Brasil ${ }^{13}$, positivado com a Lei Complementar nำ5 de 1988 (LCP 95/98), a unidade principal, e básica, de articulação jurídica é o artigo. O agrupamento de artigos formará uma Seção (excepcionalmente pode ser decomposta em Subseções), um conjunto de Seções forma um Capítulo que quando agrupados formam um Título. Muito embora tais termos sejam explicitados, não há definição ou critério formal de sistematização que indique como os artigos devem ser agrupados em seções, capítulos e assim

\footnotetext{
12 Recurso Extraordinário no 160.486.

${ }^{13}$ Segundo o Manual de Redação da Presidência da República, Manual de Redação da Câmara dos Deputados, Manual de Redação da Assembleia de Minas Gerais, Manual de Elaboração de Textos do Senado Federal e LCP 95/98
} 
sucessivamente. Embora os manuais recomendem que os agrupamentos sejam formados por temas semelhantes, são sujeitos à discricionariedade dos constituintes, já que a semelhança e mesmo as denominações são subjetivas. Com isso não é esperado que haja constância nos agrupamentos de artigos entre as Constituições Estaduais ou mesmo entre elas e a Federal.

$\mathrm{Na}$ mesma linha, a composição de um artigo é também sujeito à discricionariedade, mesmo que os manuais e orientações supracitados recomendem que cada artigo deverá se restringir a um único assunto ou princípio. Estruturalmente, os artigos também podem ser desdobrados em caput, parágrafos, incisos, alíneas e itens, dependendo de sua complexidade. Caso o artigo seja desdobrado, o dispositivo inicial será o caput, que tem função de enunciação e identificação da matéria. $O$ parágrafo tem por objetivo restringir, expandir, detalhar ou fazer ressalvas ao preceito enunciado no caput, é uma disposição secundária que explica ou modifica o preceito principal. Já os incisos, alíneas e itens são utilizados para enumerar e discriminar múltiplos elementos do caput ou parágrafo a que se referem.

A estrutura formal das Constituições delimita o conjunto de normas, princípios e disposições dotados de relevância jurídica, portanto da estrutura formal temos a divisão das Constituições em Preâmbulo, texto principal e ADCT. Já a estrutura organizacional indica como o texto é escrito, como suas normas são organizadas, agrupadas e qual organização lógica que permite a interpretação e a atribuição de significado ao texto sem que contexto não escrito seja necessário, então é essa organização que identifica de que forma o texto constitucional se organiza em Títulos, capítulos, artigos, parágrafos, etc.

Utilizamos a estrutura formal para delimitar quais trechos são relevantes para a análise. Da interpretação do STF, o preâmbulo, por não possuir caráter jurídico, normativo, será desconsiderado. As Disposições Permanentes e o ADCT, em virtude de sua equivalência jurídica, são considerados componentes equivalentes do texto Constitucional. Mas, dada as especificidades e natureza distinta destes trechos, também serão apresentados de forma desagregada quando relevante.

Já a estrutura organizacional é base para delimitação dos níveis de análise, e instrumentalização das variáveis. Ao contrário da estrutura formal, em que decisão do STF determina a interpretação que deve ser dada, na questão organizacional não há 
consenso, portanto é de se esperar certa variabilidade na organização dos textos constitucionais. Os agrupamentos maiores, dado seu caráter arbitrário de formação e organização, devem passar por sistematização e compilação segundo um critério único que permita a comparação.

A análise então se dará sobre o texto principal (excluído o preâmbulo) e o ADCT, e a unidade de análise se concentrará nos artigos, agrupamentos, palavras e estruturas sintáticas com significado de acordo com a unidade de medida utilizada. Ao medir a extensão constitucional, levando em consideração as condições acima, tem-se a ideia de captar os comandos legais, as normas, exauridas ou não, que compõe as Cartas, e não a extensão em seu sentido literal. Para tanto diversas unidades de medida, e métodos de cálculo de tais medidas, podem ser utilizadas.

\subsection{Perfil e extensão constitucional}

As constituições estaduais promulgadas após a Constituição Federal de 1988, por mais que tenham apresentado tempo de elaboração virtualmente igual ${ }^{14}$, possuem tamanhos distintos. O tamanho das Constituições pode ser medido com base em diferentes métodos, cada um com suas peculiaridades. Duas correntes podem ser identificadas, uma textual, outra estrutural. Pelos métodos textuais as constituições são medidas de acordo com características textuais, tais como a contagem de caracteres, o número de linhas (LORENZ, 2005), de parágrafos (ANCKAR; KARVONEN, 2002), e a medida usualmente utilizada, o número de palavras (BERKOWITZ; CLAY, 2005; GINSBURG, 2010; LUTZ, 1994; NEGRETTO, 2012; TSEBELIS; NARDI, 2014; VOIGT, 2009). Já as medidas estruturais levam em consideração o texto constitucional em si, tentam captar seu conteúdo, sua organização lógica, algumas formas são o número de artigos (MONTENEGRO, 1995), o escopo (ELKINS; GINSBURG; MELTON, 2009) e o número de dispositivos constitucionais (ARANTES; COUTO, 2009; COUTO; ARANTES, 2002, 2006). Com o objetivo de avaliar e comparar alguns desses métodos utilizaremos três formas de

\footnotetext{
${ }^{14}$ Se considerarmos nossos dados de tempo de elaboração.
} 
medir o tamanho das Constituições, número de artigos, número de palavras e número de dispositivos.

\subsubsection{Artigos}

A forma mais direta de medir o tamanho de uma Constituição é pela contagem do número de artigos. Segundo Montenegro (1995), o número de artigos indica a diversidade de matérias e sub-tópicos abordados bem como o grau de detalhamento almejado pelos constituintes. Ademais é uma variável de instrumentalização objetiva, que, segundo o autor, não possui influência significativa da tradição linguística/cultural, o que a torna propícia a comparações entre países. No caso dos estados brasileiros a diferença linguística não é relevante, mesmo que existam variantes linguísticas entre as regiões. O Gráfico 2.1 mostra o tamanho total das Constituições estaduais, ordenadas de forma crescente, quando promulgadas e a quantidade de artigos na CF com o objetivo de comparação.

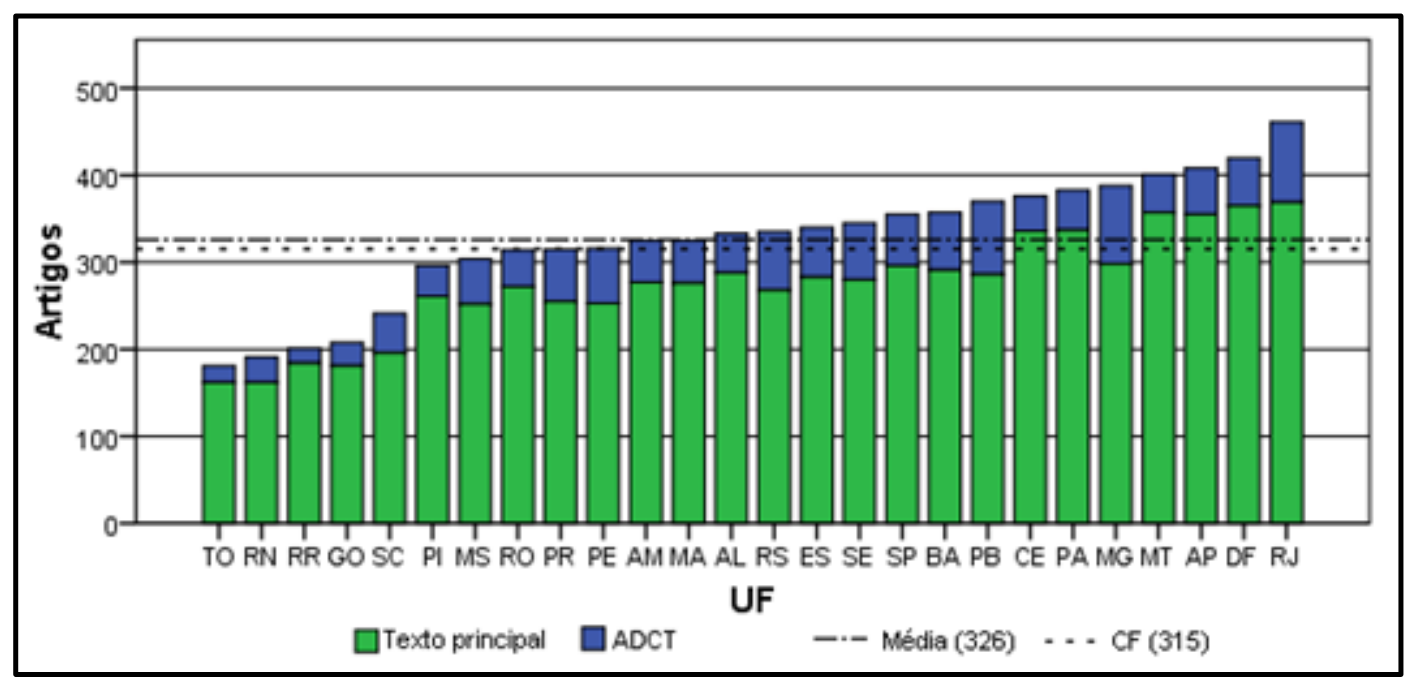

Gráfico 2.1 - Extensão, em artigos, das Constituições Estaduais

Do gráfico podemos notar que algumas Constituições se destacam por tamanho elevado ou reduzido, embora haja certa concentração em torno da média. Do número de artigos vemos que, em média, as constituições estaduais são 
ligeiramente maiores do que a Constituição Federal. Apenas 8 dos $26^{15}(30,76 \%)$ estados possuem Constituição menor que a Federal. Quando o texto é desagregado em principal e ADCT, a maioria das Constituições Estaduais possui corpo principal mais extenso, por outro lado poucos são os estados com ADCT maior que o da CF. ${ }^{16}$ Com isso, caso a soma de artigos seja utilizada como medida de tamanho, temos que as Constituições Estaduais brasileiras são, em sua maioria, maiores do que a Constituição de 1988.

A menor Constituição é a de Tocantins, com 181 artigos, e a maior é a do Rio de Janeiro, com 461 artigos. Em um primeiro momento esses valores indicam variabilidade considerável no tamanho nas Constituições. Mas, quando medidas de dispersão e de tendência central são avaliadas ${ }^{17}$, a dispersão, embora existente e significativa, não se mostra tão intensa. Os estados possuem em média 326 artigos e um coeficiente de variação de $22,2 \%$.

A mediana, de 334, encontra-se entre Alagoas e Rio Grande do Sul. Metade dos estados possui entre 297 e 371 artigos (no gráfico, de MS a PB, inclusive) e a outra metade encontra-se fora deste intervalo. Ou seja, $50 \%$ dos estados encontramse em um intervalo de 74 artigos ao redor da mediana, o que indica que mesmo que haja estados com constituições muito extensas ou muito reduzidas, metade dos estados possui diferença máxima de 74 artigos.

Os cinco menores estados se destacam no gráfico, mas apenas Tocantins e Rio Grande do Norte são considerados valores discrepantes (outlier). Quando o texto é desagregado e consideramos os tamanhos do ADCT e do corpo principal, Tocantins e Rio Grande do Norte também possuem os menores corpos principais, com 162 artigos (também são valores discrepantes), e entre os 5 menores ADCT. Avaliamos também a possibilidade de associação entre a extensão desses trechos, o que sugeriria que a extensão, em artigos, é afetada por alguma variável que influencia tanto extensão do corpo principal quanto do ADCT. Há correlação significativa entre

\footnotetext{
${ }^{15}$ Removemos o Acre da análise já que não conseguimos o texto da Constituição original nem do emendamento deste estado.

${ }^{16} \mathrm{O}$ texto principal de 21 das $26(80,8 \%)$ Constituições Estaduais é mais extenso que o da CF. Já o ADCT de apenas 3 das 26 (11,5\%) Constituições Estaduais é mais extenso que o ADCT Federal.

17 Ver Apêndice A.2.
} 
as variáveis. O que significa que o tamanho do corpo principal e o tamanho do ADCT possuem certa associação positiva ${ }^{18}$.

Segundo o Manual de Redação da Presidência da República19 "Artigo é a unidade básica para apresentação, divisão ou agrupamento de assuntos num texto normativo. [...] Os artigos podem desdobrar-se, por sua vez, em parágrafos e incisos; e estes, em alíneas." (BRASIL, 2002). Sendo assim um Artigo, por mais que possua uma definição formal estabelecida em Lei Complementar, e explicado em manuais de redação legislativa, não possui uma definição fechada. O que faz com que um conjunto de provisões seja caracterizado, ou agrupado, em um mesmo artigo, é a compreensão dos constituintes de que aquelas provisões tratam de tema único. Ou seja, está sujeito à discricionariedade do constituinte. Como consequência, parecenos problemático medir o tamanho de uma Constituição pelo total de artigos. Como não há critério sistemático, restritivo, acerca do que caracteriza um artigo ou não, este fica a critério da subjetividade do constituinte. Assim a objetividade da variável, tal como proposta por Montenegro (1995), não pode ser assegurada por este método.

Ademais, Tsebelis e Nardi (2014) argumentam que não se sabe as razões pelas quais os constituintes dividem tópicos em artigos distintos, de forma que tal separação, se não arbitrária, segue princípios não conhecidos, de cada constituinte. Desse modo, ao utilizar a quantidade de artigos como unidade de medida da extensão Constitucional, o que é medido de fato não é a extensão em si da Constituição, mas a quantidade de divisões em tópicos que os constituintes julgaram tratar de tema semelhante o suficiente para que fossem agregados. Isto é, ao contar artigos não contamos a quantidade de normas constitucionais, mas sim a quantidade de agrupamento que os constituintes identificaram segundo um tema. Então se o objetivo é avaliar a quantidade de normas constitucionais, a contagem de artigos acaba distorcendo essa informação. Uma vez que um artigo pode conter uma série de normas e é segundo a decisão discricionária do constituinte que determinadas normas são semelhantes o suficiente para que sejam agregadas em um único artigo, ou se distintas o suficiente para que sejam divididas em dois ou mais. Esta característica de

\footnotetext{
${ }^{18}$ Não há qualquer inferência de causalidade. A correlação pode levantar a possibilidade de variáveis afetando a extensão constitucional, o que seria transmitido para ambos trechos, fazendo com que o tamanho do corpo principal e do ADCT apresente certa semelhança.

${ }_{19}$ Lei Complementar № 95, de 26 de Fevereiro de 1988, estabelece normas para redação de matéria legislativa no Brasil.
} 
cada constituinte, e portanto de cada AEC, pode ser um dos fatores que explica a existência de associação entre a extensão, em artigos, do corpo principal e do ADCT, já que as preferências por mais síntese e compilação dos tópicos, ou mais fragmentações, pode ser pessoal.

\subsubsection{Palavras}

A utilização do número de palavras como unidade de medida de um texto constitucional possui as vantagens de não estar sujeito à subjetividade do constituinte na definição de temas e agrupamentos, mesmo que esteja sujeito a sua prolixidade e redação. Além disso fornece instrumentalização objetiva da variável tamanho, já que contam-se as palavras. Esta medida de tamanho é frequentemente utilizada na literatura e tratada tanto como variável dependente como independente, o que faz com que o número de palavras se torne importante medida de extensão. A ideia de medir o tamanho do texto constitucional pela contagem de palavras é captar os conceitos e conteúdo da constituição de forma indireta (HAMMONS, 1999; LUTZ, 1994; TSEBELIS; NARDI, 2014), uma vez que não são avaliados os temas em si, mas somadas as palavras, que consideradas com valor equivalente, são uma proxy da quantidade de matérias dispostas na constituição. Segundo esta abordagem constituições mais extensas possuem mais matérias constitucionalizadas, mais provisões propriamente ditas.

A contagem de palavras apresenta problemas de ordem linguística. Além de quaisquer duas palavras possuírem o mesmo peso independente de extensão ou significado, as constituições devem ser traduzidas para uma mesma língua, uma vez que comparar palavras em línguas distintas não é eficaz. No caso das Constituições Estaduais Brasileiras não há necessidade de adaptação linguística, haja visto que provém do mesmo país, com língua oficial única e diretrizes para redação jurídica. Ademais, Por isso a barreira linguística não deve ser encontrada, nem a equivalência de pesos deve gerar distorções. O tamanho, em palavras, das constituições encontrase no Gráfico 2.2 ordenado de forma crescente. 


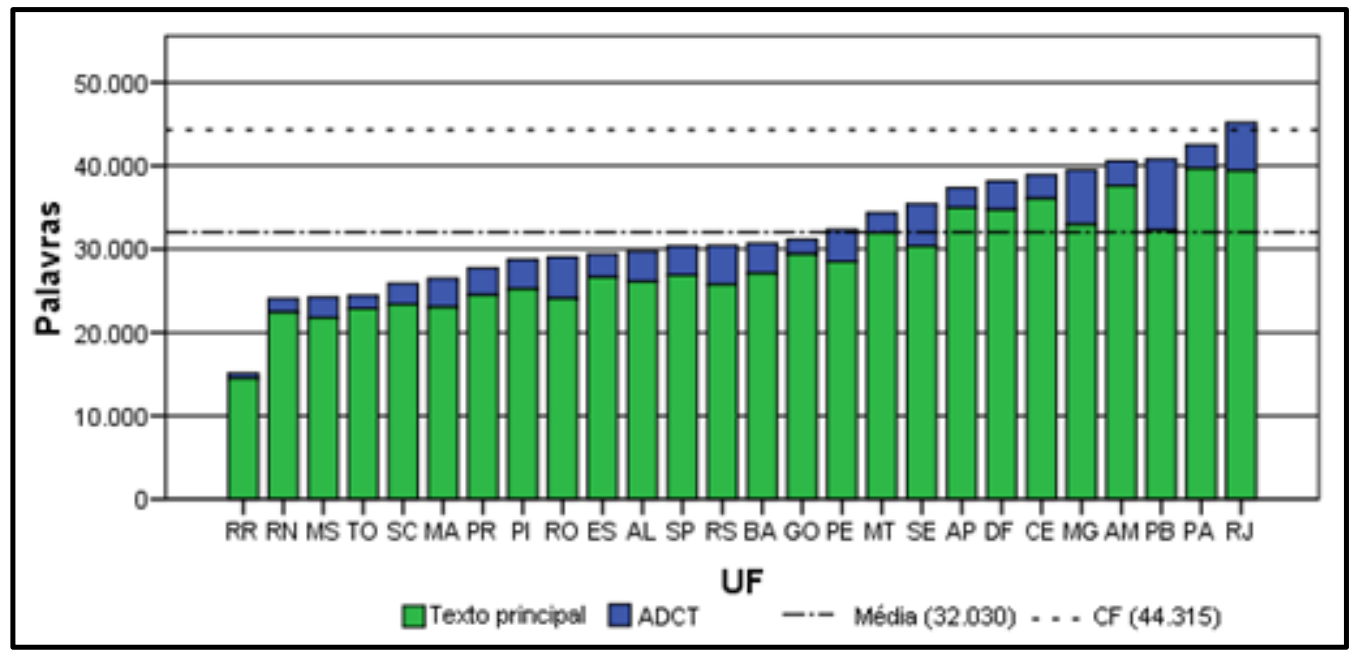

Gráfico 2.2 - Extensão, em palavras, das Constituições Estaduais.

Primeiramente podemos notar que o formato do gráfico de palavras se assemelha ao formato do gráfico de artigos. Em média as Constituições Estaduais possuem 32.031 palavras em seus textos, quando comparado com a extensão da CF vemos que esta é consideravelmente maior. Com 44.315 palavras a CF apresenta texto $38,35 \%$ mais extenso do que a média de extensão estadual. Apenas o Rio de Janeiro possui Constituição maior, em quantidade de palavras, do que a Federal. Quando o texto é desagregado encontramos três estados com maior texto principal e um estado com ADCT maior, mas são casos isolados ${ }^{20}$. Os estados que possuem texto principal mais extenso são Amazonas, Pará e Rio de Janeiro, e o estado que possui ADCT mais extenso é a Paraíba, sendo que o número elevado de palavras no ADCT deste é consequência de seu Art. $55^{21}$.

A menor Constituição, em palavras, é a de Roraima, com 15.132 palavras, a maior é a do Rio de Janeiro, com 45.206. Pelo gráfico vemos que assim como em número de artigos, as Constituições possuem número de palavras variado. Das

\footnotetext{
${ }^{20} \mathrm{O}$ texto principal de 23 das 26 (88,5\%) Constituições Estaduais possui menor quantidade de palavras que o da CF. O ADCT de 25 das 26 (96,2\%) Constituições Estaduais apresenta menor extensão que 0 da CF. A média de palavras no texto principal das Constituições Estaduais é $22 \%$ menor que a quantidade de palavras no mesmo trecho da CF. Já no ADCT a média de palavras entre os estados é menor que a metade do ADCT Federal.

${ }^{21}$ Este determina a elevação de distritos judiciais da Paraíba à condição de município. É o maior artigo, ou norma, encontrado nas Constituições Estaduais. Seu caput se desdobra em 66 incisos (até o inciso LXVI), o artigo possui 2.859 palavras divididas em 72 dispositivos. Apenas este artigo é mais extenso do que o ADCT de 9 outros estados.
} 
medidas descritivas ${ }^{22}$ vemos que esta variabilidade não é acentuada, com um coeficiente de variação de 21,75\%. A mediana se situa entre Rio Grande do Sul e Bahia, ao passo que encontramos 50\% dos estados com Constituição entre 25.814 e 35.350 palavras (no gráfico, de SC a MT), sendo esta concentração mais elevada no intervalo inferior à mediana. Deste intervalo, e da comparação com as outras medidas, o Brasil possui maior número de estados com Constituições relativamente menores, mas aquelas que possuem elevado número de palavras são suficientemente grandes para deslocar a média total.

Do Gráfico 2.2 podemos notar que a Constituição de Roraima é consideravelmente menor do que a dos outros estados, seja em tamanho total, em tamanho do corpo principal ou mesmo do ADCT. Esta Constituição corresponde a aproximadamente metade do tamanho da média de extensão entre os estados e possui cerca de 10.000 palavras a menos (62,8\% da extensão) que a segunda menor Constituição. Porém, em razão da dispersão da variável, não se caracteriza como valor discrepante no sentido estatístico.

Quando o texto é desagregado, a comparação dos estados em quartis do tamanho do texto principal e do ADCT não apresenta constância, isto é, os estados com maiores e menores corpos principais não são os estados com maiores e menores ADCT. Após análise não foi possível encontrar associação (linear ou monotônica) significativa entre as variáveis. Mas, segundo Tsebelis e Nardi (2014), espera-se efeito marginal decrescente quando utiliza-se número de palavras, isto é, há maior diferença entre 1.000 e 2.000 palavras do que entre 10.000 e 11.000 palavras, mesmo que a variação absoluta seja igual, portanto deve-se utilizar transformação logarítmica no número de palavras para que a análise seja viável. Quando os dados são transformados encontramos que a associação linear entre as variáveis é significante, no entanto, como efeito da transformação, Roraima torna-se outlier e compromete os resultados, se removido, não é mais possível encontrar associação (linear ou monotônica) significativa entre as variáveis. Portanto, mesmo com transformação logarítmica não é possível afirmar que há associação (linear ou monotônica) entre o tamanho do texto principal e o tamanho do ADCT, quando medidos em palavras.

${ }^{22}$ Os dados detalhados encontram-se no Apêndice A.3. 
2.3.3. Dispositivos

O terceiro método de medir a extensão constitucional consiste na contagem de dispositivos. A Metodologia de Análise Constitucional (MAC), desenvolvida por Arantes e Couto (2002; 2006; 2009; 2010), tem por objetivo não só medir a extensão constitucional, mas também captar e classificar o conteúdo das constituições. Quando aplicada integralmente não há necessidade de utilizar a extensão constitucional como proxy da quantidade ou natureza das matérias constitucionalizadas, a classificação do conteúdo explicita estas variáveis. Muito embora a classificação do conteúdo de cada constituição não seja o escopo de nosso trabalho, seu método de medir a extensão constitucional será utilizado.

Segundo Couto e Arantes (2002), dispositivo é uma unidade básica que compõe o texto constitucional. $\mathrm{Na} \mathrm{MAC}$, as Constituições são decompostas em unidades mínimas dotadas de significado lógico. Não há relação necessária entre um tópico constitucional ${ }^{23}$ e um dispositivo, cada tópico constitucional pode ou não ser dividido em um ou mais dispositivos, dependendo da sua natureza sintática.

Mesmo que a ideia de medir a extensão Constitucional seja semelhante entre os três modos, é de se esperar diferenças significativas, já que cada modo de instrumentalizar a extensão será afetado por fatores distintos. Ao contrário das outras unidades de medida apresentadas, a divisão em dispositivos não prejudica a capacidade de comparação entre textos constitucionais, sejam eles de mesma origem ou não. Por mais que também exista certa subjetividade devido à estrutura textual das Constituições, não é de se esperar que seja tão afetada pela discricionariedade do constituinte quanto a extensão medida por artigos. Como trata-se de enunciado lógico, as diferenças e barreiras linguísticas também serão reduzidas, espera-se que a verbosidade e prolixidade do legislador tenham efeito reduzido. Ademais, segundo Noronha (2014), o número de palavras consiste em método sem orientação teórica que acaba por mascarar o tamanho real de uma constituição bem como seu conteúdo.

A utilização de dispositivo como unidade de medida faz com que a variável extensão constitucional se aproxime mais da extensão de interesse da Constituição,

${ }^{23}$ Artigo, parágrafo, inciso, alínea e item. 
e não da extensão literal. Qual seja, da quantidade de provisões, normas e especificações presentes nas Cartas em vez de o tamanho do texto escrito propriamente dito. A contagem de dispositivos por Constituição estadual encontra-se, em ordem crescente, no Gráfico 2.3.

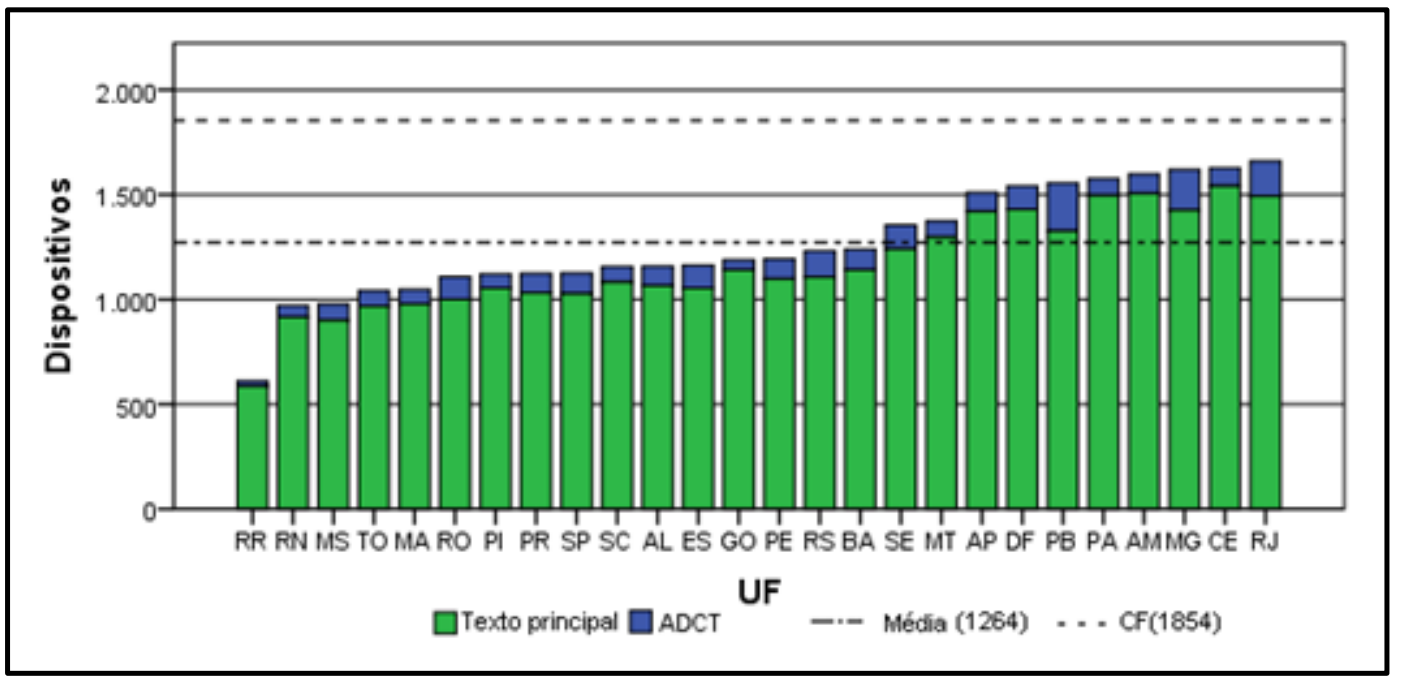

Gráfico 2.3 - Extensão, em dispositivos, das Constituições Estaduais

Do gráfico vemos que as Constituições Estaduais são consideravelmente menores do que a CF. Não só em média, mas também em valores absolutos. A média de dispositivos nas Constituições Estaduais é de 1.264, ao passo que a CF possui 1.854 dispositivos, dessa maneira a CF é 46,67\% maior do que a média estadual. Ademais não há estado com Constituição mais extensa que a Federal. A maior CE, do Rio de Janeiro, com 1.661 ainda é menor em 193 dispositivos que a CF, correspondendo a $86,9 \%$ do tamanho desta. Quando os textos são desagregados essa diferença se mantém para os textos principais e se intensifica para o ADCT ${ }^{24}$. Mas dada a dimensão reduzida dos ADCT comparados com o tamanho total das Constituições, o impacto final é reduzido.

A menor Constituição é a de Roraima, com 610 dispositivos (e apenas 23 dispositivos no ADCT) e a maior é a do Rio de Janeiro, com 1.661. Do Gráfico 2.3

${ }^{24}$ O texto principal da CF é 39,44\% maior do que a média encontrada (1.167) nas Constituições estaduais e também não há estado com texto principal mais extenso. Já o ADCT da CF é $132 \%$ maior do que a média estadual (98), em contrapartida a Paraíba possui ADCT maior do que o Federal (1 dispositivo a mais apenas), provavelmente em virtude do Art. 55 daquela. A dispersão nos ADCT é considerável, com $44,2 \%$ de coeficiente de variação. 
podemos notar que a Constituição de Roraima é significativamente menor do que as outras Constituições estaduais, sendo a única que possui menos de 1.000 dispositivos. Contudo, em virtude das características da variável, Roraima não é considerada outlier no sentido estatístico.

Apesar de o Gráfico 2.3 indicar variabilidade, as medidas de tendência central e dispersão demonstram o contrário. Com média de 1.264 dispositivos e coeficiente de variação de 20,55\% a dispersão se mostra menos intensa. A mediana encontrada foi de 1.191 dispositivos, situada, no gráfico, entre PE e GO. O intervalo entre TO e BA (de 1.034 a 1.348, com amplitude de 314 dispositivos) concentra $50 \%$ dos estados. Já os sete estados com maior Constituição (de DF a RJ) se encontram em um intervalo de 124 dispositivos (de 1.541 a 1.661 dispositivos). Portanto o tamanho medido em dispositivos das Constituições Brasileiras possui duas faixas que concentram a maioria dos estados. Uma contém maior frequência de Constituições de menor extensão, localizada entre TO e GO, totalizando dez estados em um intervalo de 148 dispositivos. A outra contém número de casos um pouco menor, mas de estados com Constituições extensas o suficiente para deslocar a média, esta se localiza entre DF e RJ, o que totaliza sete estados num intervalo de 124 dispositivos.

Ao observar as quatro maiores, e menores, extensões de textos principais e $A D C T$, vemos que não há repetição. Isto é, os estados que possuem corpo principal mais extenso não condizem com os estados com maiores ADCT, muito embora dois dos quatro menores sejam repetidos. Quando calculadas as medidas de associação 25 não é possível encontrar associação linear, embora haja associação monotônica positiva. Mas tal associação também desaparece quando os valores extremos são removidos. O que indica que não parece haver relação entre número de dispositivos no ADCT e no corpo principal. Ou seja, os dados não sugerem a existência de fator que afete em conjunto a extensão constitucional, como a discricionariedade sugerida por Tsebelis e Nardi (2014).

\subsection{Comparação entre medidas}

\footnotetext{
${ }^{25}$ Os dados detalhados encontram-se no Apêndice A.4.
} 
Ao utilizarmos três formas diferentes de medir o tamanho das constituições, embora o objetivo seja medir o mesmo fenômeno, qual seja, a extensão constitucional em termos de normas e provisões, cada uma das medidas apresentadas possui características únicas, com distintas vantagens e desvantagens. Assim sendo, o objetivo ao comparar as três unidades de medida é destacar suas diferenças e identificar aquela com maior verossimilhança com o objeto de estudo. Outro ponto é que, ao cruzar as informações obtidas, novas características das Constituições podem aparecer, visto que cada medida possui pressupostos distintos, método distinto e nível de análise distinto, mesmo que o objeto de estudo seja o mesmo. O contraste entre elas pode revelar informações sobre as Constituições em si que não seriam captadas ao utilizá-las de forma isolada.

Os três indicadores de extensão constitucional diferem significativamente na unidade de medida, sendo assim a comparação direta não é viável. As medidas descritivas encontradas para cada uma delas isoladamente nada significam quando comparadas entre si. Para permitir a comparação utilizamos medidas que não consideram a natureza diferente das variáveis. Uma primeira consequência dos diferentes métodos de medir a extensão Constitucional é a dispersão de cada variável. Para compará-los utilizamos o Coeficiente de Variação e RMADM²6. A Tabela 2.2 contém as medidas de dispersão ponderadas.

\footnotetext{
${ }^{26}$ Median Absolute Deviation from the Median (MADM): Esta medida de dispersão indica a mediana dos desvios absolutos da mediana. É um valor de corte utilizado para construir um intervalo ao redor da mediana que faz com que metade das observações se encontrem no intervalo gerado. Ou seja, metade das observações estão mais próximas da mediana do que o valor encontrado para o MADM e metade está mais distante. Com mediana de 334 artigos e MADM de 37, sabemos que $50 \%$ dos estados possuem 37 ou menos artigos de diferença da mediana. Como $50 \%$ dos estados se encontram no intervalo [297; 371], então os outros $50 \%$ se encontram no intervalo complementar.

Relative Median Absolute Deviation from the Median (RMADM): De forma análoga ao coeficiente de variação consiste na razão entre a medida de dispersão $(M A D M)$ e a medida de tendência central (mediana). Da mesma forma que o coeficiente de variação, remove a unidade de medida e permite comparação entre diferentes escalas.
} 
Tabela 2.2 - Medidas de Dispersão Relativa na Constituição e por trecho desagregado

\begin{tabular}{llccc}
\hline & & Constituição* & ADCT & $\begin{array}{c}\text { Texto } \\
\text { Principal }\end{array}$ \\
\hline Coeficiente de & Artigo & $22,19 \%$ & $36,87 \%$ & $21,82 \%$ \\
Variação & Palavra & $21,75 \%$ & $48,24 \%$ & $21,57 \%$ \\
& Dispositivo & $20,55 \%$ & $44,23 \%$ & $20,15 \%$ \\
& & & & \\
\hline \multirow{2}{*}{ RMADM } & Artigo & $11,08 \%$ & $19,80 \%$ & $8,80 \%$ \\
& Palavra & $15,59 \%$ & $25,47 \%$ & $15,00 \%$ \\
& Dispositivo & $13,18 \%$ & $19,13 \%$ & $12,42 \%$ \\
\hline
\end{tabular}

*. Constituição Completa

Os coeficientes de variação são relativamente constantes entre as diferentes unidades de medida tanto para a Constituição total como para seus textos desagregados, o que demonstra dispersão equivalente. Se utilizamos métodos mais robustos (RMADM) os valores extremos exercem menos influência na dispersão e ao contrário da primeira medida, a quantidade de palavras é relativamente mais dispersa do que a quantidade de artigos e dispositivos ${ }^{27}$ e a dispersão dos dispositivos se aproxima, mas ainda é menor - com exceção do ADCT - que a dispersão de artigos. Esta diversidade pode ser explicada devido à magnitude e natureza hierárquica das unidades de medida, já que um artigo possui no mínimo um dispositivo que por sua vez possui pelo menos uma palavra. Dos dados, a extensão dos textos principais é consideravelmente menos variável do que a extensão dos ADCT, mesmo para as medidas robustas, mas a elevada variabilidade dos ADCT não é suficiente para elevar significativamente a dispersão das Constituições completas.

\footnotetext{
${ }^{27}$ Pela razão entre os RMADM a quantidade de palavras é $40 \%$ mais dispersa que os artigos e $18 \%$ mais dispersa que os dispositivos. Enquanto os dispositivos são 19\% mais dispersos que os artigos.
} 


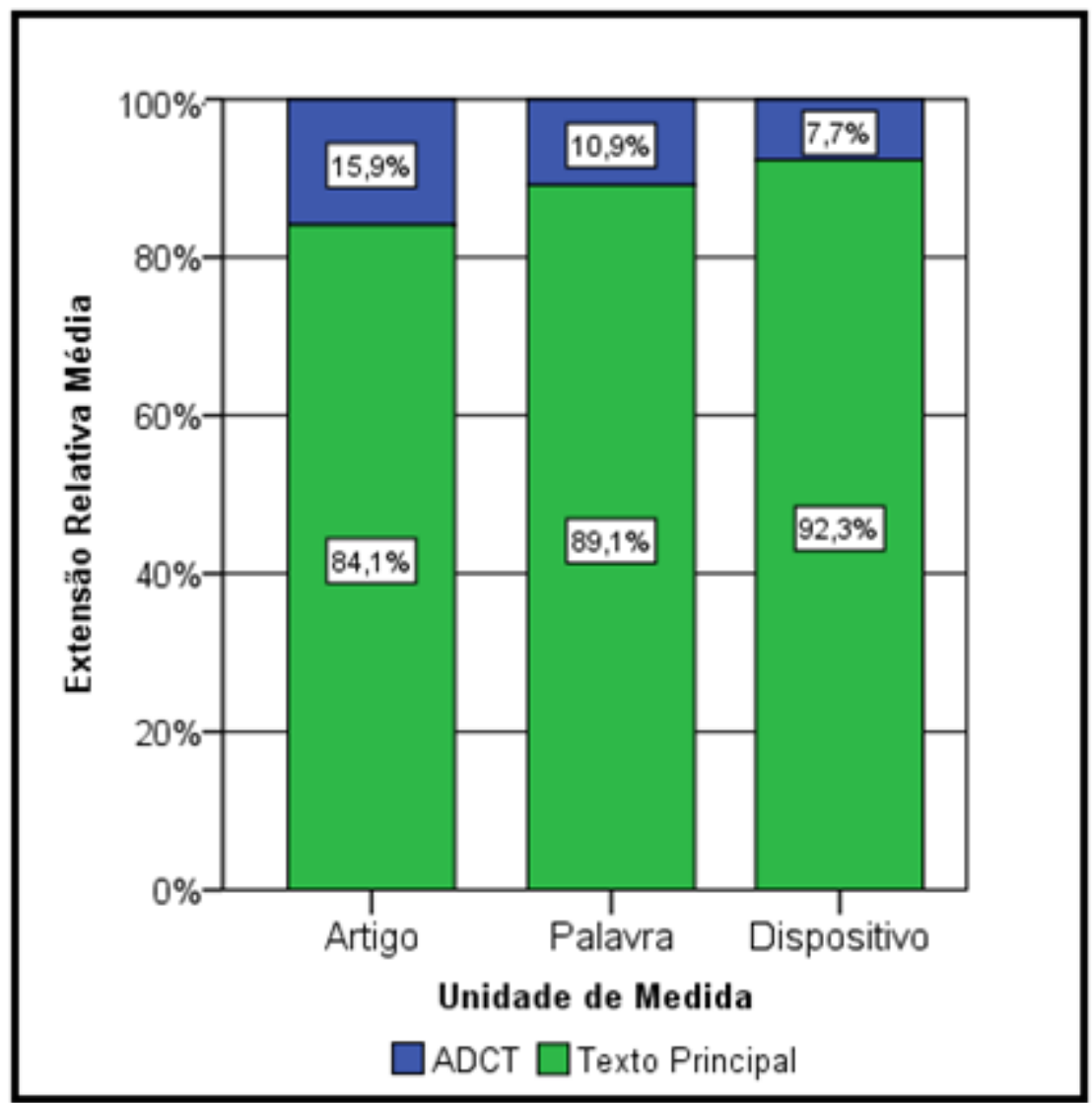

Gráfico 2.4 - Proporção média dos trechos desagregados nas três unidades de medida

A influência reduzida dos ADCT no texto total se dá em razão de sua proporção reduzida frente às Constituições. Assim por mais que aquele trecho seja significativamente mais disperso, independente da unidade de medida utilizada, esta não causa alteração na constituição completa. No Gráfico 2.4 temos a média de tamanhos relativos das constituições desagregadas em cada unidade de medida. Em média os ADCT correspondem a 15,9\%, 10,9\% e 7,7\% das Constituições completas quando medimos em artigos, palavras e dispositivos, respectivamente. A título de comparação, as proporções relativas do ADCT na CF são 22,2\%, 17,4\% e 12,24\%. O tamanho relativo é significativamente diferente para as três unidades de medida e quando comparamos com a CF temos que esta possui ADCT proporcionalmente maior que a média estadual.

Ao ranquear as Constituições Estaduais para cada uma das unidades de medida, salvo AM e GO, não há muita diferença entre as posições relativas de cada Estado. Enquanto Amazonas é o estado com a quarta maior Constituição (em 
palavras e dispositivos), torna-se a decima quinta quando utilizamos a contagem por artigo; Goiás, em artigos é o estado com vigésima terceira maior constituição (ou seja, terceira menor), já em número de palavras e dispositivos ocupa a décima segunda e décima quarta. As maiores, e mais frequentes, variações de posição ocorrem quando comparamos o ranking de artigo com as outras unidades de medida. Isso aponta para distorção causada ao utilizar essa unidade de medida e reitera a hipótese de Tsebelis e Nardi (2014) de que não se sabe os motivos pelos quais um constituinte escolhe agrupar ou não determinados temas.

Como os artigos são agrupamentos de dispositivos que por sua vez são agrupamentos de palavras podemos utilizar as frações inferiores para medir as frações superiores. Isto é, além de medir as Constituições (e seus desdobramentos) em artigos, dispositivos ou palavras, podemos medir os artigos em dispositivos ou palavras, e os dispositivos em palavras ${ }^{28}$. Para a comparação nos limitamos a medir os artigos em número de palavras e dispositivos. A Tabela 2.3 contém o tamanho médio dos artigos das Constituições Estaduais ${ }^{29}$.

Tabela 2.3 - Média, máximo e mínimo dos artigos Constitucionais

\begin{tabular}{llccc}
\hline Medida & Trecho & Média & Máximo & Mínimo \\
\hline \multirow{2}{*}{ Palavra } & Constituição & 98,1 & 2.859 & 6 \\
& Texto Principal & 104,2 & 1.476 & 6 \\
& ADCT & 67 & 2.859 & 9 \\
\hline \multirow{2}{*}{ Dispositivo } & Constituição & 3,9 & 72 & 1 \\
& Texto Principal & 4,5 & 46 & 1 \\
& ADCT & 1,9 & 72 & 1 \\
\hline
\end{tabular}

Embora a extensão dos artigos não seja o objeto de estudo, ao medi-los conseguimos informações sobre as unidades de medida. A quantidade média (e total) de palavras nos artigos que compõe o texto principal é maior que nos artigos no ADCT,

\footnotetext{
${ }^{28}$ Por consequência da omissão das repetições desnecessárias o número de palavras por dispositivo é subestimado.

${ }^{29}$ Neste caso as observações não são a extensão de cada Constituição Estadual, mas sim a extensão de cada artigo nas Constituições estaduais. Portanto o número de observações é 8.489 , ou todos os artigos presentes nos textos estaduais.
} 
no entanto este apresenta 4 valores discrepantes ${ }^{30}$ que acabam por distorcer a média. O mesmo se repete para a medida em dispositivos. Ao medir os artigos em palavras e dispositivos podemos notar que a quantidade de artigos nas Constituições não é uma boa medida da extensão, já que os artigos variam de 6 a 2.859 palavras, e de 1 a 72 dispositivos.

Se o objetivo da medida de extensão é captar a frequência de normas constitucionalizadas, quando contamos artigos consideramos equivalentes um artigo com 6 palavras e um com 2.859 palavras, um com 72 dispositivos (ou provisões) e um com apenas 1 dispositivo. Assim, uma importante conclusão a que podemos chegar é que a contagem por número de artigos distorce significativamente a medida da extensão constitucional. A despeito desta distorção, é de se esperar que haja certa relação entre as variáveis, uma vez que dispositivos e palavras podem ser vistos como desdobramentos do artigo em unidades menores. Como as unidades estão em magnitudes distintas as escalas foram omitidas no Gráfico 2.5 com o objetivo de destacar a relação entre as variáveis.

${ }^{30}$ São eles PB (2.859), RO (2.721), PI (1.514) e MA (1.292). 


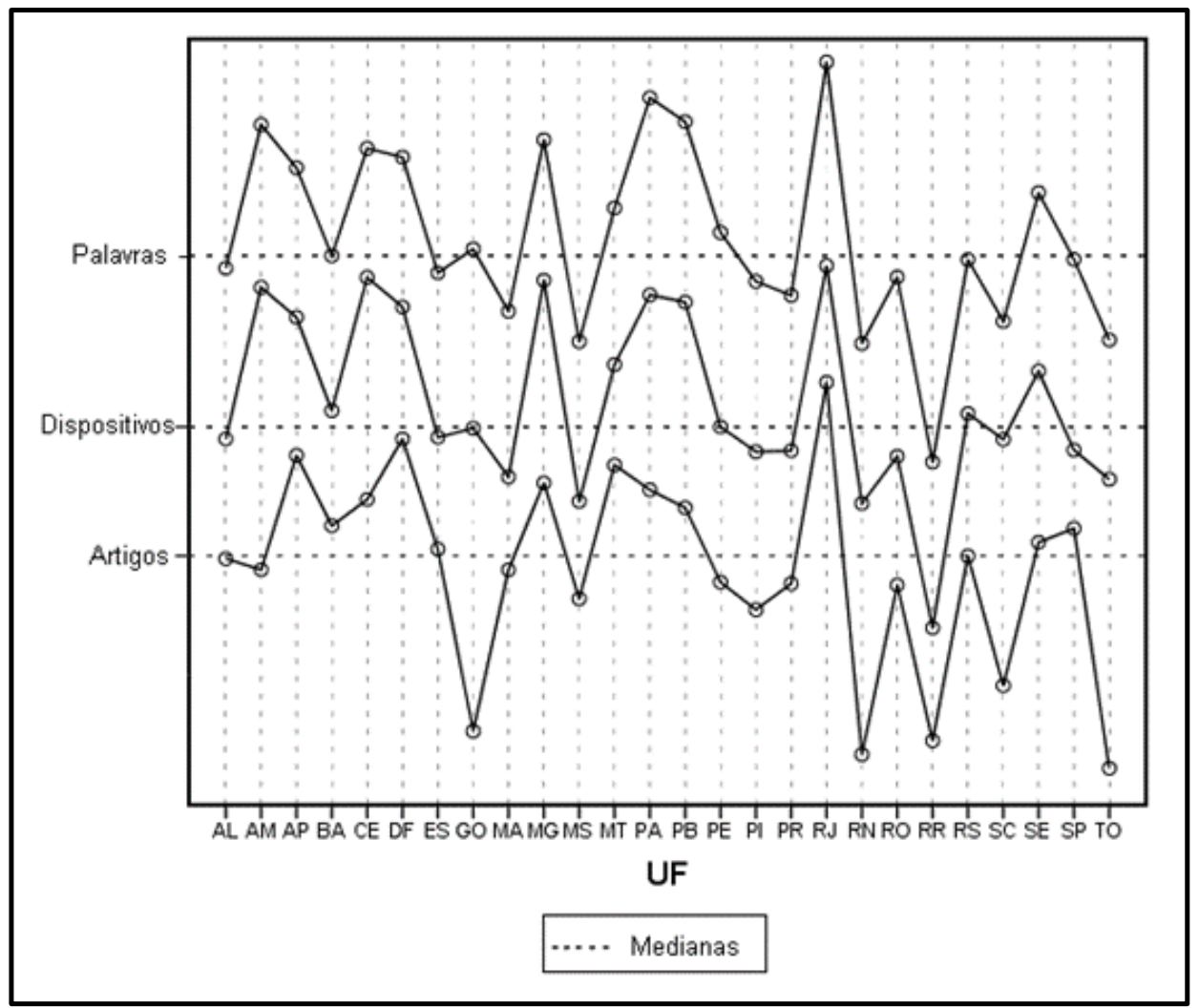

Gráfico 2.5 - Extensão das Constituições Estaduais nas três unidades de medida com linhas de interpolação e mediana, sem escala

Do Gráfico 2.5 é possível notar a semelhança entre as três unidades de medida. Muito embora as variáveis sejam discretas, as linhas foram adicionadas para facilitar a visualização, portanto não indicam tendência ou continuidade. As linhas tracejadas indicam a mediana de cada variável. Pela posição de cada estado com relação à mediana, em cada uma das formas de medir a extensão constitucional, vemos que não há muita variação de posição, salvo alguns casos, ou seja, por mais que as três medidas sejam diferentes, o resultado encontrado por elas quando medimos as Constituições Estaduais brasileiras se assemelham. Mesmo a medida de artigo, por mais que não apresente a mesma equivalência que palavras e dispositivos apresentam entre si, podemos dizer que é significativamente próxima. Como explicitado pelo ordenamento das Constituições, Amazonas e Goiás destoam quando utilizamos o número de artigos como unidade de medida.

Mesmo em escalas diferentes as unidades de medida são consideravelmente equivalentes. A fim de reduzi-las a uma mesma magnitude efetuamos transformações 
lineares na quantidade de palavras e de dispositivos. Para a quantidade de palavras a transformação foi dividir por cem, para os dispositivos, por quatro. O Gráfico 2.6 expõe as três variáveis ${ }^{31}$ no mesmo eixo, os artigos foram mantidos constantes e as palavras e dispositivos são transformações lineares.

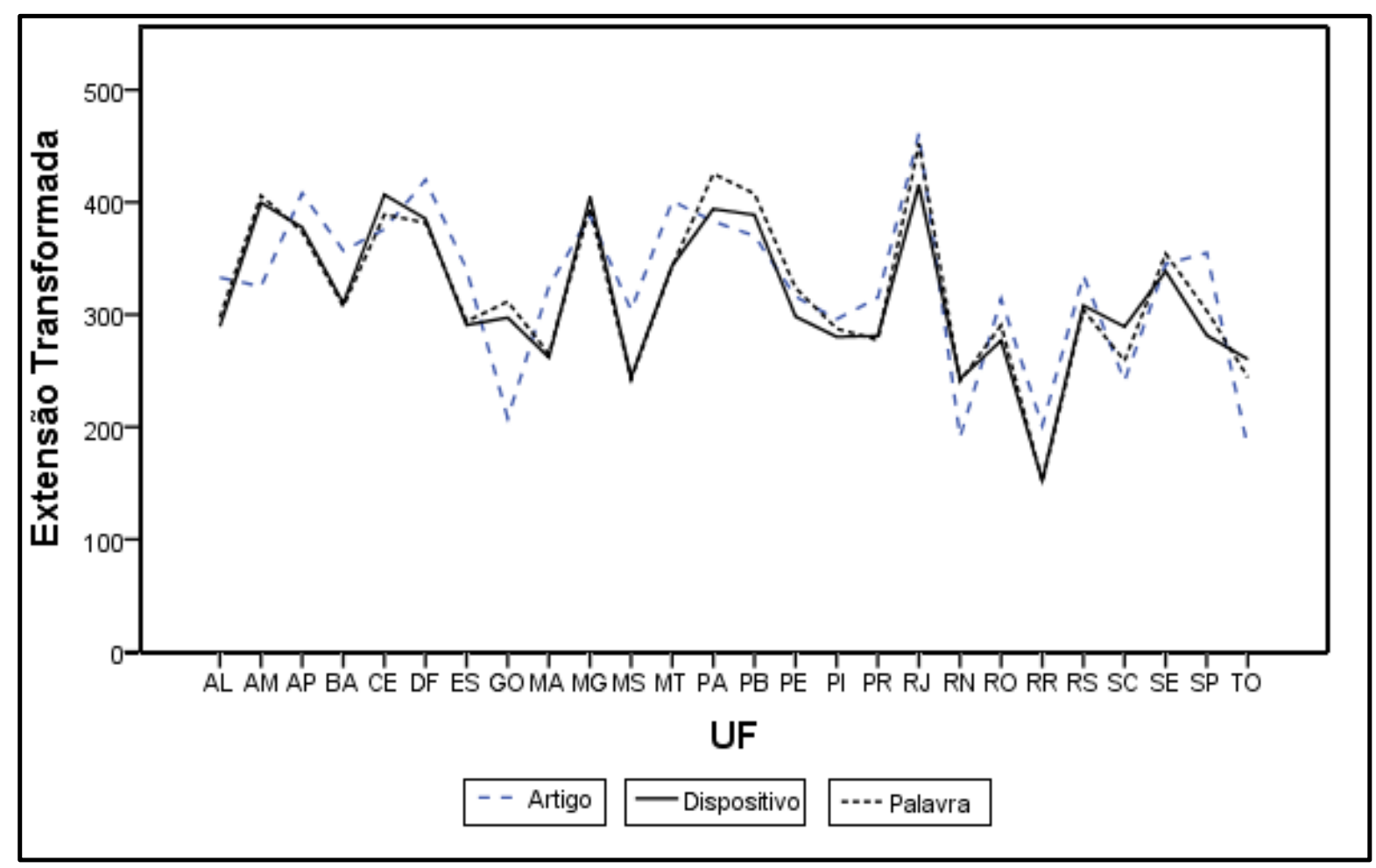

Gráfico 2.6 - Extensão Constitucional com medidas transformadas

Ao reduzir os tamanhos para uma escala comparável vemos que as semelhanças são marcantes, especialmente entre quantidade de dispositivos e palavras. A fim de comparar a relação bidimensional entre as variáveis, o Gráfico 2.7, exibe uma matriz que contém os diagramas de dispersão das medidas de tamanho por estado. Cada ponto, em cada um dos seis gráficos, representa a Constituição de um estado e indica seu tamanho quando medido em duas unidades diferentes, encontradas nos eixos $\mathrm{X}$ e $\mathrm{Y}$ da matriz. Optamos por omitir os eixos de escala com o objetivo de ressaltar a disposição e formato da nuvem de pontos e não a relação numérica entre essas unidades de medida.

${ }^{31}$ O sumário estatístico encontra-se no Apêndice A.5. 


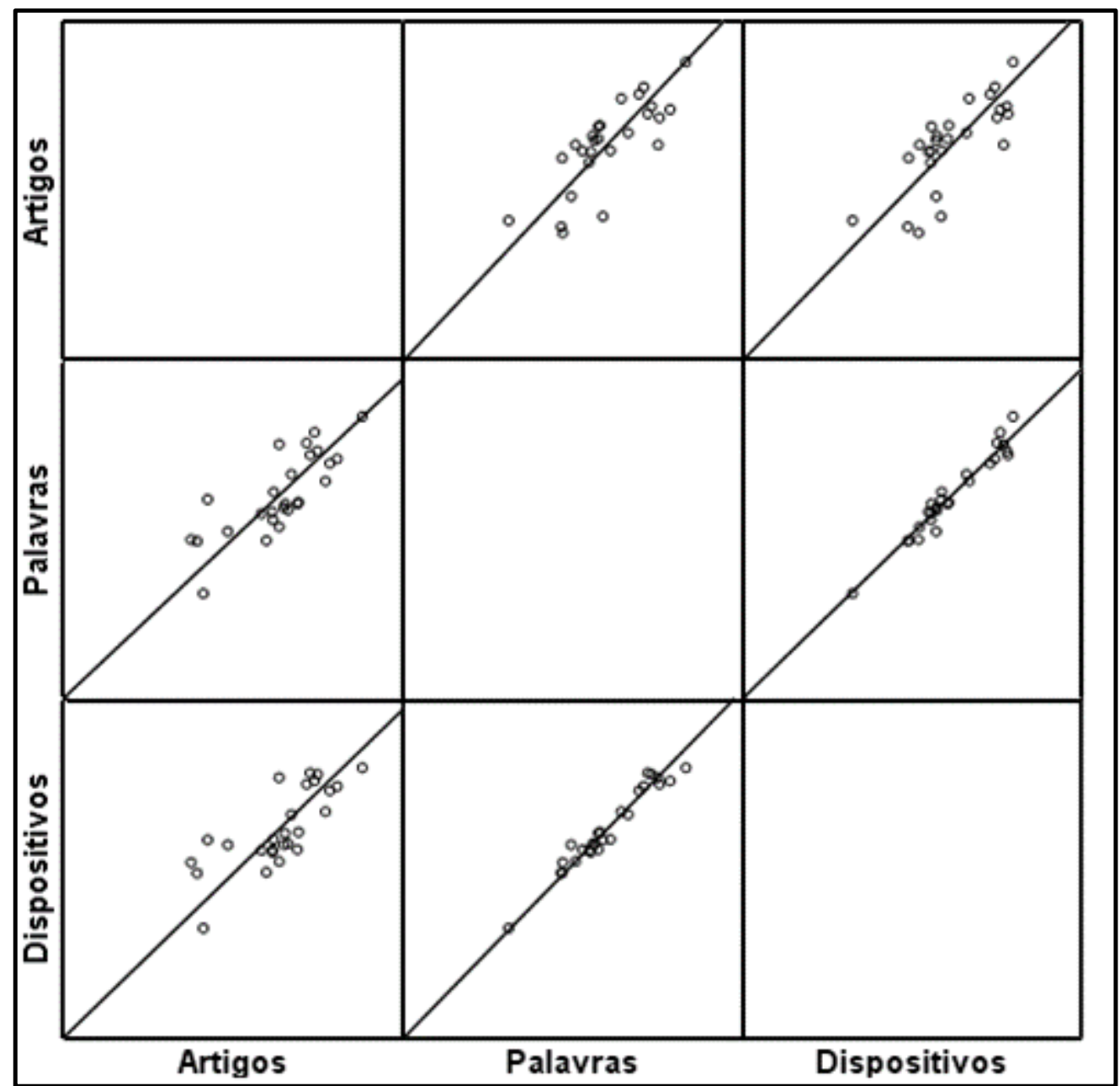

Gráfico 2.7 - Matriz de gráficos de dispersão entre as medidas de extensão Constitucional por estado com linha de tendência

Embora as escalas tenham sido omitidas, todos os gráficos possuem zero como ponto de origem. Podemos notar que para qualquer par de variáveis parece existir relação linear positiva. Sabendo que um artigo sempre será composto por pelo menos um dispositivo que por sua vez é composto por pelo menos uma palavra, então existe certa verticalização entre as três unidades de medida. Com isso a relação positiva entre as unidades de medida é esperada. Com efeito as linhas de ajuste sem intercepto - corroboram a relação positiva e também indicam relação linear exposta nos gráficos acima.

Dos gráficos, quando cruzamos o tamanho por artigo com as duas outras unidades de medida, embora uma relação linear e positiva seja aparente, esta não se mostra tão intensa quando comparada com a relação entre dispositivos e palavras. Em contrapartida os gráficos indicam que o tamanho em palavras e o tamanho em 
dispositivos nas Constituições Estaduais possuem relação estreita se aproximando da equivalência perfeita. A Tabela 2.4 contém as correlações entre as três unidades de medida, o que permitirá melhor avaliação e quantificação das relações.

Tabela 2.4 - Coeficientes de Correlação entre as unidades de medida

\begin{tabular}{|c|c|c|c|}
\hline & & Artigos & Palavras \\
\hline \multirow[t]{2}{*}{ Palavras } & Pearson & $\begin{array}{l}0,787^{*} \\
(0,000)\end{array}$ & \\
\hline & Spearman & $\begin{array}{l}0,810^{*} \\
(0,000)\end{array}$ & \\
\hline \multirow[t]{2}{*}{ Dispositivos } & Pearson & $\begin{array}{c}0,764^{*} \\
(0,000)\end{array}$ & $\begin{array}{l}0,975^{\star} \\
(0,000)\end{array}$ \\
\hline & Spearman & $\begin{array}{l}0,821^{*} \\
(0,000)\end{array}$ & $\begin{array}{c}0,960^{\star} \\
(0,000)\end{array}$ \\
\hline
\end{tabular}

* Significativo no nível 0,01 (2 extremidades).

** P-valor entre parênteses.

Encontramos coeficientes de correlação altamente significativos para as três combinações entre as medidas. Embora o coeficiente de correlação de Pearson tenha sua viabilidade prejudicada em razão da ausência de pressuposto ou indicação de normalidade, sua magnitude corrobora o encontrado nos diagramas de dispersão. Com efeito encontramos o coeficiente de postos de Spearman, assim também a correlação não-paramétrica indica que há forte associação monotônica positiva entre as variáveis. Mesmo que haja correlação positiva, significativa e forte, vemos que na nuvem de pontos a relação entre artigo e as outras medidas não é tão exata, existe certa variabilidade. Isto reforça a hipótese de que a discricionariedade do constituinte na divisão dos artigos possui efeito significativo. No mesmo sentido a correlação positiva entre quantidade de palavras e dispositivos é esperada, no entanto a intensidade desta correlação é característica marcante.

Os coeficientes de correlação formalizam o encontrado nos gráficos e fornecem uma quantificação da proximidade real entre as unidades de medida. Mesmo que a correlação linear não possa ser estatisticamente afirmada, dos gráficos de dispersão, das linhas de interpolação e do coeficiente de Spearman, temos indícios 
que a relação entre dispositivos e palavras, se não perfeitamente linear, se aproxima dela. Com efeito a correlação encontrada quando utilizamos as variáveis transformadas não é diferente.

Com um coeficiente de correlação de 0,960 (ou 0,975 para Pearson), e, no diagrama de dispersão, vemos que a relação entre quantidade de palavras e quantidade de dispositivos fica próxima da correlação perfeita. Grosso modo podemos afirmar que $92,16 \%$ da variação em dispositivos é explicada ${ }^{32}$ pela variação em palavras - e vice-versa - ou há outras variáveis que afetam simultaneamente a extensão nestas unidades de medida.

A relação média entre a quantidade de palavras e dispositivos - tomando a quantidade de dispositivos como base - é de 1 para 25. Isto é, com variação de uma unidade de dispositivo é esperada variação de 25 palavras (ou em média, uma variação de 25 palavras é encontrada com uma variação média de 1 dispositivo, novamente não há inferência de causalidade). Quando as variáveis são padronizadas o efeito esperado é de 0,999, isto é, para uma variação média de uma unidade na quantidade de palavras ou dispositivos padronizados, esperamos variação média de 0,999 na outra. A relação estabelecida entre quantidade de palavras e dispositivos é então muito próxima da linear, no entanto é possível que esta correlação seja espúria, sendo fruto do acaso ou de alguma variável que determina ambas.

Com proporcionalidade desta magnitude a utilização de uma ou outra unidade de medida para o caso das Constituições Estaduais brasileiras estudadas não deve causar alterações ou desvios significativos, uma pode ser utilizada como proxy quase perfeita da outra. Esta proximidade pode indicar que ambas são eficientes como unidades de medida da extensão constitucional, quando consideramos que o objetivo é medir a quantidade de normas constitucionalizadas. Admitindo que as constituições escritas possuem uma quantidade verdadeira, observável, de normas ou provisões, ao utilizar o modelo de contagem por palavras ou dispositivos conseguimos captar de forma semelhante a extensão real. Este cenário não significa que são as mais eficientes formas de medir a extensão, mas sim que possivelmente medem o mesmo

\footnotetext{
${ }^{32}$ Novamente não há inferência ou pressuposto de causalidade.
} 
objeto e encontram resultados equivalentes. Esta suposição necessita de maiores testes e informações para ser avaliada.

As três unidades de medida de extensão constitucional utilizadas possuem não só método de instrumentalização da variável distinto mas também refletem diferentes fenômenos. Se a divisão em artigos indica quantas normas os constituintes agruparam segundo seus critérios próprios, ela não capta de fato a extensão normativa. Abaixo dos artigos temos os dispositivos, estes podem ser vistos como desdobramentos dos artigos, já que apenas um conjunto (de um ou mais) dispositivos compõe um artigo.

Sendo o dispositivo a subdivisão do artigo em suas provisões normativas, aquele consegue captar mais fielmente a quantidade de normas existentes em uma Constituição por captar as normas dentro de um artigo. Mas, da mesma forma como o artigo, os dispositivos podem ser compostos por mais de uma norma que o constituinte decidiu agregar. A quantidade de dispositivos sofre de problema semelhante da contagem de artigos, já que encontramos normas idênticas, em diferentes estados, compondo número distinto de dispositivos. Mas, por se tratar de grau maior de divisão esse efeito é diluído. Analogamente aos artigos, os dispositivos são compostos por palavras.

As palavras são subdivisão dos dispositivos, por conseguinte dos artigos e finalmente das Constituições. No entanto o fato de ser subdivisão do dispositivo não significa que dilui o possível efeito da subjetividade do constituinte. Enquanto a contagem de artigos considera artigos de tamanhos distintos como equivalentes, a contagem de palavras considera pronomes, substantivos, verbos, etc. com igualdade. Ademais a contagem de palavras sofre de barreiras linguísticas quando utilizada para comparar textos de diferentes origens linguísticas.

As três unidades de medida tem por objetivo instrumentalizar a extensão constitucional no sentido de quantidade de normas elevadas a marco constitucional, e as três sofrem de interferências de outros fatores. Não podemos considerar que a extensão constitucional em qualquer das três formas reflita, de fato, a quantidade verdadeira de normas elevadas a marco constitucional. Portanto a escolha por uma 
forma de medida é a escolha de um modelo que melhor explica, ou capta, o fenômeno extensão constitucional.

No caso dos estados brasileiros a utilização de palavras não afeta a capacidade de comparação por se tratar da mesma língua, mas quando comparamos constituições de origens linguísticas distintas a contagem de palavras é distorcida por esta barreira e afetada pela prolixidade. Nesse sentido Noronha (2014) encontra diferença significativa quando comparamos constituições de línguas diferentes. No caso, em palavras a Constituição Federal é $23,35 \%$ do tamanho da Constituição Indiana, em dispositivos essa proporção é de $98,24 \%$. Com isso, mesmo que para os estados brasileiros as contagens de palavras e de dispositivos se aproximem, ao utilizar o número de palavras a viabilidade de outras comparações é reduzida.

Mesmo que os artigos sejam a unidade normativa básica composta por normas e provisões, o agrupamento das mesmas em um artigo pode sofrer influência significativa de fator subjetivo inerente à cada legislador. Da mesma forma, a divisão de dispositivos, além de também ser possivelmente influenciada por fator subjetivo, considera normas extensas ou curtas, com impacto elevado ou reduzido, como equivalentes. Por outro lado a contagem de dispositivos reduz a distorção causada pela subjetividade devido à maior especificidade, permite a comparação entre diferentes línguas, e se situa de forma intermediária entre as palavras e os artigos. Isto é, não é tão abrangente quanto os artigos, e nem tão específica (ou textual) quanto o número de palavras. Ademais por não ser tão minimalista como as palavras pode também ser utilizada como observação, como é feito na Metodologia de Análise Constitucional, cuja aplicação integral está fora de nosso escopo.

Pela comparação entre as diferentes unidades de medida temos que do ponto de vista puramente quantitativo, isto é, em uma abordagem exclusivamente estatística, a utilização de dispositivos ou palavras não deve causar qualquer alteração significativa nos resultados. Nesta mesma abordagem quantitativa, a utilização do número de artigos também é viável, mesmo que incorra em maiores distorções. No entanto, a escolha por uma ou outra unidade de medida não deve se resumir unicamente ao seu caráter estatístico mesmo que a contagem de palavras, artigos e dispositivos seja estatisticamente equivalente. A escolha de uma ou outra unidade de medida incorrerá em consequências metodológicas tanto quantitativas 
quanto qualitativas, mas seu impacto principal será de caráter qualitativo, já que o significado e interpretação das diferentes unidades de medida é distinto. Portanto nossa escolha pela contagem de dispositivos, unidade de medida que demanda mais trabalho em sua instrumentalização, leva em consideração não só suas características quantitativas, mas principalmente suas vantagens qualitativas, como maior capacidade informativa, por permitir a identificação de diferentes características de cada dispositivo, comparativa, em virtude de considerar elementos lógicos, e finalmente em razão da possibilidade de melhor quantificação e classificação do emendamento, questões que serão discutidas posteriormente.

\subsection{Agrupamentos e padronização}

Tanto a Constituição Federal quanto as Constituições Estaduais tem suas normas categorizadas em agrupamentos maiores. Um conjunto de dispositivos forma um artigo, os artigos com temas semelhantes são agrupados em seções, em seguida em capítulo e finalmente em título. Esses agrupamentos tem a finalidade de organizar e compartimentalizar o texto Constitucional. Não há distinção hierárquica entre as divisões, assim uma norma que trata dos princípios fundamentais do estado não é, no sentido jurídico, mais ou menos importante que uma norma que trata da gratuidade do transporte público. Mas é de se esperar que tais normas se encontrem em títulos diferentes por consequência de seus temas diferentes. Se a medida de extensão adotada é destinada a captar a quantidade de normas elevadas a marco constitucional, ao avaliar a extensão de cada conjunto de normas temos a possibilidade de comparar quais Estados, ou Textos Constitucionais, versam mais sobre um ou outro tema, ou quais temas são mais extensamente normatizados nas Constituições Estaduais e Constituição Federal, entre outros.

Para avaliar os temas mais frequentes nas cartas medimos também a extensão das Constituições Estaduais e Federal desagregadas em seus títulos. Como não há definição formal que caracterize, limite ou defina esses agrupamentos, a arbitrariedade do constituinte torna-se evidente. Não só na determinação de quais temas se organizam sob quais títulos, capítulos e seções, mas também na própria nomenclatura. A estrutura encontrada tanto nas Constituições Estaduais quanto na 
Constituição Federal impede qualquer tipo de comparação dos agrupamentos maiores.

Encontramos ampla variedade de títulos, capítulos, seções e subseções. Não só temas distintos, mas nomes e níveis distintos também ${ }^{33}$. O conjunto de normas que em uma Constituição é caracterizado como uma seção, em outra pode ser um título. No total encontramos mais de 150 Títulos, 400 capítulos e 600 seções únicas. Como o banco de dados conta com a Constituição de vinte e seis estados, a comparação entre variedade tão elevada não forneceria informação confiável, salvo a corroboração de que os constituintes de fato não possuem critérios estabelecidos e compartilhados para a organização estrutural das Constituições que não o seu entendimento idiossincrático de como os temas devam ser agrupados.

Entretanto, parte da variedade é apenas fruto de nomenclatura e organização distinta. Embora sob níveis e nomes distintos, o fato é que as Constituições tratam de temas semelhantes. Como as divisões são arbitrárias e não há regime jurídico diferenciado, uma redução da diversidade de sumários constitucionais a um modelo padrão torna viável a análise. Sendo assim, renomeamos e reagrupamos os artigos das Constituições Estaduais, assegurada a semelhança de seus conteúdos. O resultado da classificação foi a organização de todos os textos Constitucionais na seguinte base de Títulos ${ }^{34}$ :

1. Dos Princípios, Direitos e Garantias Fundamentais.

2. Do Estado.

3. Da Organização dos Poderes.

4. Da Segurança Pública.

5. Da Tributação e Orçamento.

6. Da Ordem Econômica.

7. Da Ordem Social.

8. Disposições Constitucionais Gerais.

\footnotetext{
${ }^{33}$ Por exemplo, a Constituição do Ceará contém o "Título VIII - Das Responsabilidades Culturais, Sociais e Econômicas", este contém, além de outros, o "Capítulo X - Da Política Urbana" e "Capítulo XI - Da Política Agrícola e Fundiária". Na Constituição do Tocantins encontramos o seguinte "Título XII - Da Política Agrícola, Fundiária e da Reforma Agrária". Sendo que este título não se desdobra em nenhum capítulo ou seção. Esta inconstância é frequente.

${ }^{34}$ Ver Apêndice A.6. para explicação do critério de classificação e tabela com frequências absoluta e relativa de cada Título nas Constituições Estaduais bem como a estrutura completa da padronização.
} 


\section{Ato das Disposições Constitucionais Transitórias ${ }^{35}$.}

Ao padronizar os agrupamentos dos temas constitucionais a comparação torna-se possível. Por mais que os títulos em si não traduzam necessariamente o tema que é abordado pelos artigos que o compõe, há proximidade de assuntos. A classificação completa foi em Título, Capítulos e Seções, entretanto, como os Títulos tratam de temas mais abrangentes e são em menor número ${ }^{36}$, optamos por concentrar a análise neste nível de agrupamento. Além disso, para permitir a comparação entre as Cartas estaduais e a Constituição Federal utilizamos o mesmo critério para recodificar esta.

A extensão dos Títulos $^{37}$ é consideravelmente heterogênea entre as constituições. Não só seus tamanhos comparados entre si, como também quando comparados entre os estados. Apenas os Títulos 2, 3 e 7 contém $67,5 \%$ (ou 22.174) do total de dispositivos encontrados nas Constituições Estaduais, sendo o Título 3 o mais extenso, com 33,3\% (ou 10.959 dispositivos) da extensão total. Já os Títulos 1 , 4 e 8 são consideravelmente menores que os demais (671, 625 e 630 dispositivos, respectivamente), em conjunto representam apenas $5,8 \%$ da quantidade do total de dispositivos. O Gráfico 2.8 exibe o tamanho total de cada Título e o Gráfico 2.9 mostra o tamanho dos Títulos da CF em paralelo com a média de extensão dos Títulos Estaduais com intervalo de dois desvios padrão.

\footnotetext{
${ }^{35}$ Por mais que até o momento o ADCT fora tratado como um segmento distinto do texto principal, ele pode ser comparado a um título, uma vez que agrega artigos com características semelhantes. Em virtude de numeração própria e estrutura diferenciada o ADCT não necessitou de padronização.

${ }^{36}$ No total são 34 Seções agrupadas em 24 Capítulos e 9 Títulos.

${ }^{37}$ Doravante quando nos referirmos as Títulos, fazemos menção aos Títulos padronizados, e não aos encontrados nas Constituições originais.
} 


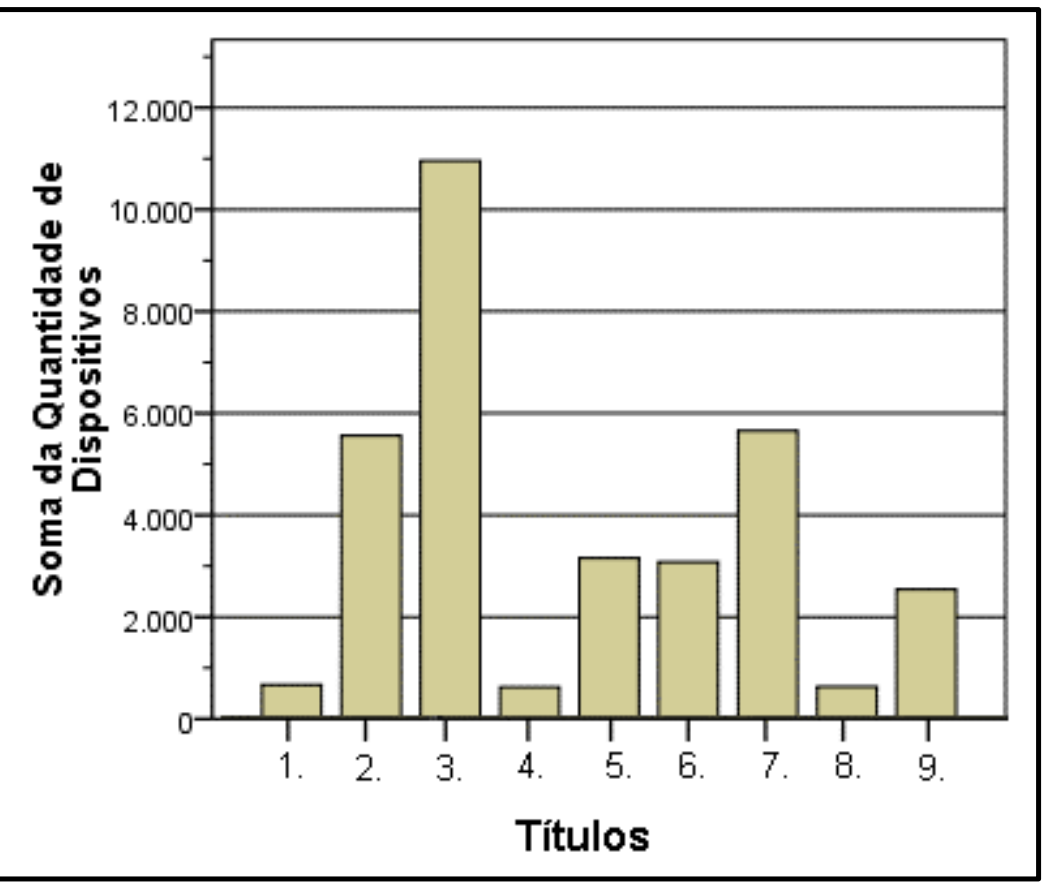

Gráfico 2.8 - Extensão total dos Títulos Padronizados nas Constituições Estaduais

A variabilidade de extensão encontrada nos Títulos estaduais é característica marcante. No Gráfico 2.9 vemos que não só a extensão dos Títulos varia consideravelmente, como varia de forma diferente entre eles, qual seja, não há homogeneidade na variação de cada Título. Enquanto os Títulos 1 e 8 possuem as maiores variações relativas, os Títulos 2 e 3 possuem as menores. Os primeiros apresentam no mínimo duas e no máximo dez vezes mais variabilidade relativa quando comparados com o grupo dos mais constantes. Outro fator marcante é que enquanto os títulos com maior variabilidade são os de menor extensão, os títulos menos dispersos estão entre os com maior extensão.

Ao comparar os Títulos estaduais entre si, além de não encontrarmos homogeneidade de variação, também não seguem distribuição semelhante enquanto conjunto ${ }^{38}$. Todavia, identificamos quatro grupos de Títulos que apresentam

${ }^{38}$ Apêndice A.6. ANOVA para avaliação das categorias de Título. 
características semelhantes. São eles os Títulos: (a) 1, 4 e 8; (b) 6, 5 e 9; (c) 2 e 7; (d) 3.

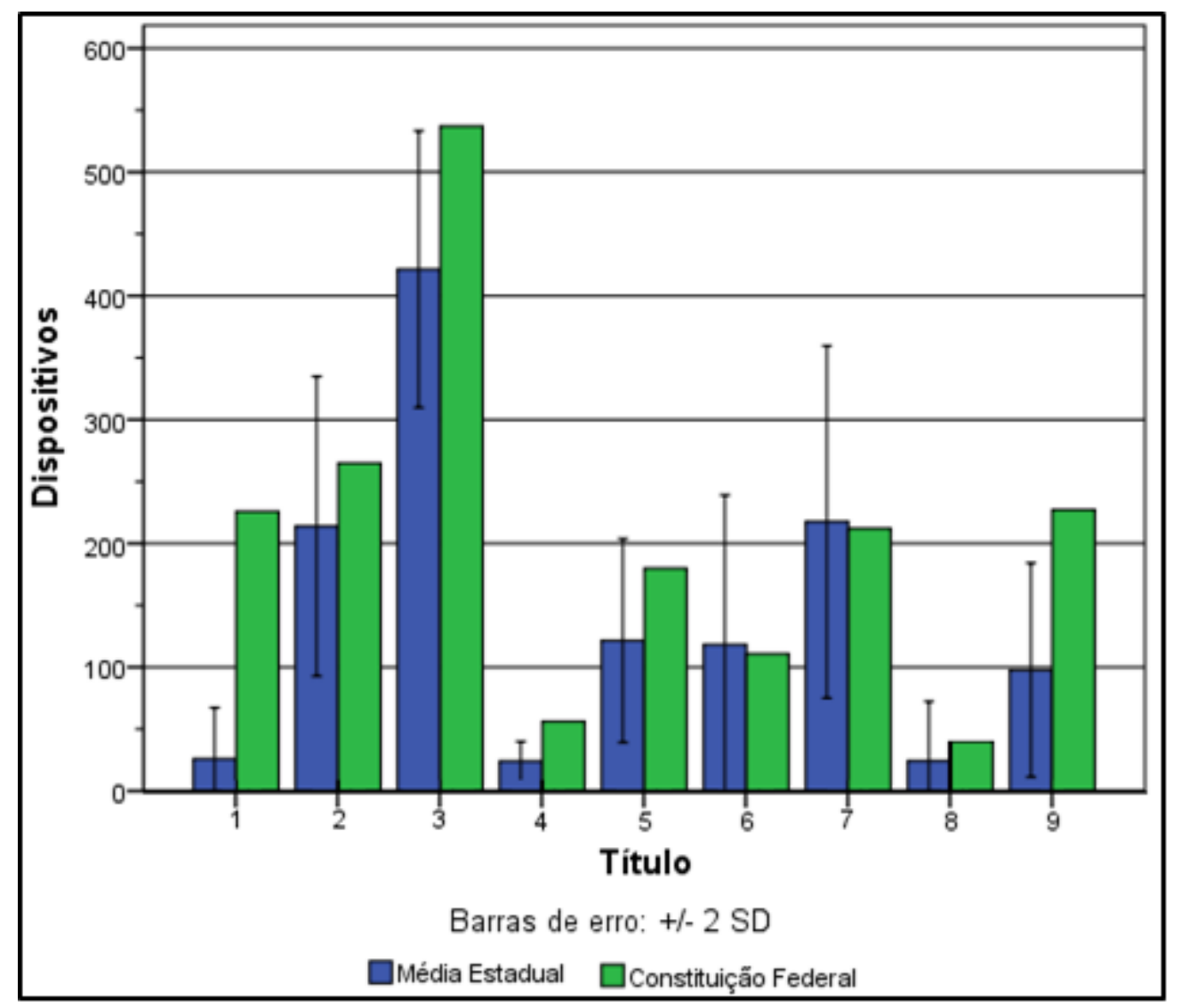

Gráfico 2.9 - Extensão Média nas Constituições Estaduais com indicação de desvio padrão e da Constituição Federal, por Título

Os conjuntos estão organizados de forma crescente, assim, não podemos afirmar que há diferença entre a quantidade de dispositivos entre os Títulos do conjunto (a), mas sabemos que os Títulos do conjunto (a) são estatisticamente diferentes dos demais e significativamente menores. O mesmo se aplica entre o (b) e os demais. Então o maior Título encontrado nas Constituições Estaduais é o Título 3, "Da Organização dos Poderes". Este Título, além de consideravelmente maior que os demais, também não possui outro que seja seu semelhante, isto é, apresenta distribuição de quantidades distinta dos demais. E quando consideramos a associação do Título com a extensão em dispositivos, vemos que aproximadamente $88 \%$ na variação da quantidade de dispositivos é explicada pela variação de Títulos. Com isso 
temos indícios de que as diferenças entre os Estados exercem influência reduzida sobre a extensão Constitucional, particularmente sobre a extensão de cada Título.

Com isso os Títulos padronizados apresentam tamanhos equivalentes entre os estados. Isto é, mesmo que exista variabilidade significativa na quantidade de dispositivos em cada Título por estado, independente do estado os Títulos apresentam intervalo de extensão que se repetem nos estados. Ademais também podemos agrupar os Títulos em conjuntos que apresentam maior similaridade e organizá-los de forma sistemática, deste modo mesmo que os Títulos não apresentem tamanhos equivalentes entre os estados, quando avaliamos a composição de cada Constituição Estadual, vemos que essa organização dos Títulos se repete, há portanto certa homogeneidade na composição proporcional das Cartas.

Ao comparar a média estadual com a extensão dos Títulos na Constituição Federal, vemos que embora a CF seja sistematicamente maior do que a média estadual, os tamanhos se aproximam, mas não testamos formalmente a existência de diferenças significativas no conjunto. Contudo no Gráfico 2.9 vemos que se situa no intervalo de dois desvios padrão ${ }^{39}$ da média de extensão Estadual. Individualmente, os Títulos que apresentam maior diferença são o Título 1 e o Título 4. Em média os estados possuem 26 dispositivos no Título 1, o que representa 11,5\% do mesmo título na Constituição Federal. O Estado com tal Título mais extenso é o RJ, com 88 dispositivos, já a CF conta com 226 dispositivos no mesmo. No caso do Título 4, a média estadual representa $43 \%$ da extensão deste Título na CF. Os demais Títulos com exceção do $\mathrm{ADCT}^{40}$ - apresentam maior proximidade com a CF.

Cada Título Estadual não parece apresentar diferenças do Título equivalente (de mesma numeração) na Constituição Federal. Assim, mesmo que a Constituição Federal seja mais extensa do que as Constituições Estaduais, o padrão de organização - a distribuição de dispositivos em diferentes temas - é semelhante. Caso o Título 1 seja removido a proximidade entre os Títulos restantes fica ainda mais

\footnotetext{
${ }^{39}$ Os únicos Títulos Federais que se situam no intervalo de $95 \%$ de confiança da média são o Título 6 , que na CF possui 111 dispositivos e o intervalo nas Constituições Estaduais é [94; 142] e o Título 7 , com 212 dispositivos na CF e intervalo da média estadual em [188; 246].

${ }^{40}$ Como o ADCT já foi explorado nas comparações anteriores, não será enfatizado.
} 
evidente. O Gráfico 2.10 ilustra a composição relativa da Constituição Federal e da Constituição Estadual média.

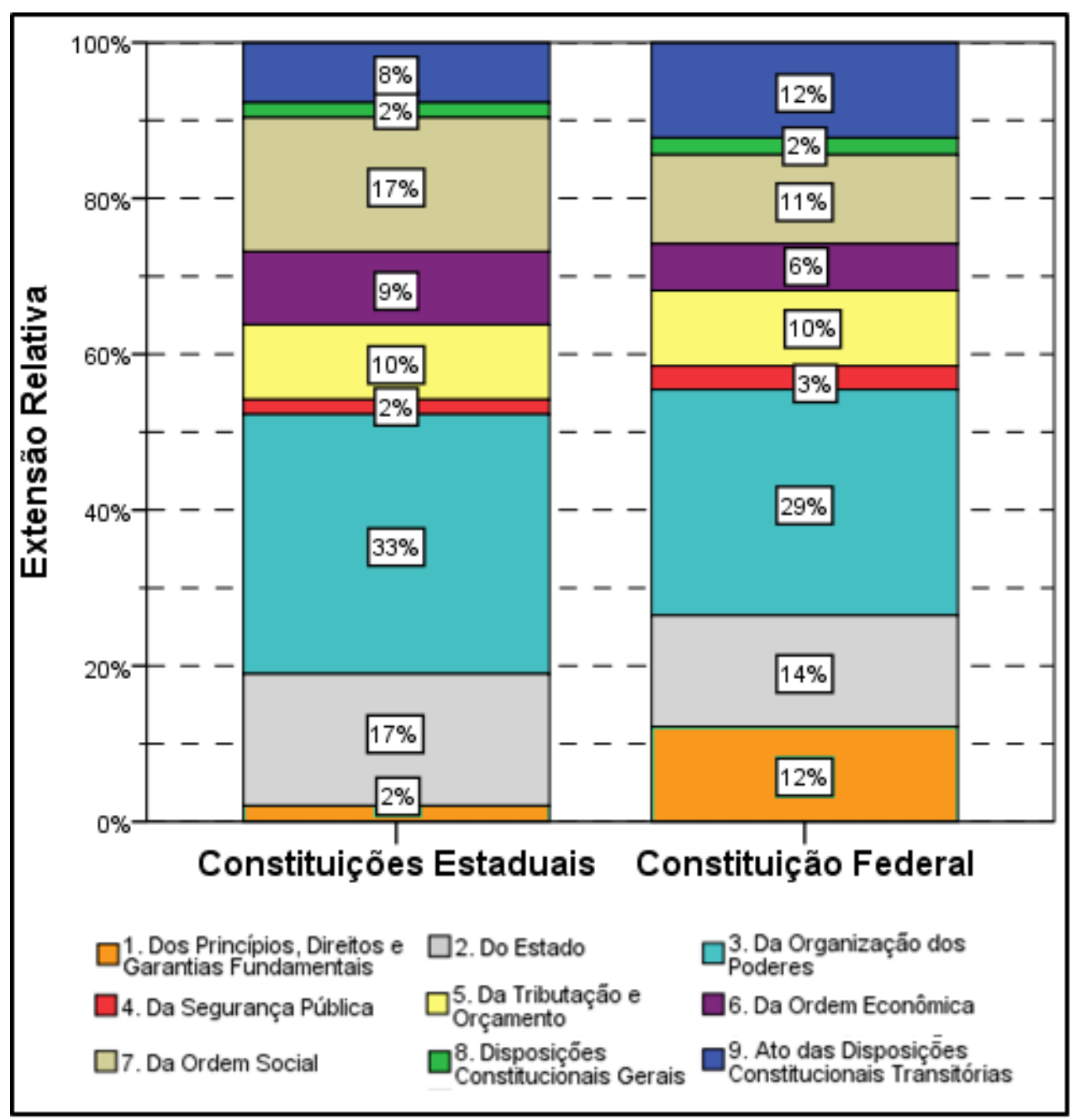

Gráfico 2.10 - Proporção Relativa dos Títulos na média das Constituições estaduais e na Constituição Federal

A composição relativa média das Constituições Estaduais é semelhante à composição relativa da Constituição Federal. Isto é, guardadas as devidas proporções, a participação de cada Título em uma Constituição é relativamente constante, seja nas Constituições Estaduais ou Federal.

Do Gráfico 2.10 vemos que a principal diferença na composição ocorre em razão do Título 1. Este título é consideravelmente mais extenso na Constituição 
Federal do que nas Constituições Estaduais seja em termos absolutos ou em média. Os demais Títulos apresentam poucos pontos porcentuais de diferença, embora a diferença dos Título 6 e 7, entre média estadual e CF, seja de apenas 3 e 6 pontos porcentuais (respectivamente), em termos relativos, são aproximadamente $50 \%$ mais extensos na média dos estados que na CF.

Quando as Constituições Estaduais são pareadas entre si, qual seja, a associação entre a composição da Constituição de AL e AM; AL e AP; AL e BA, e assim sucessivamente ${ }^{41}$ há indícios de associação positiva. Isto é, se compararmos quaisquer ${ }^{42}$ duas Constituições Estaduais, sua estrutura - a extensão de seus títulos - aparenta seguir padrão linear equivalente. Também não é possível afirmar que haja diferença significativa na distribuição de dispositivos por título entre os estados, embora haja diferença significativa entre os Títulos. Ou seja, quando controlamos por Título e comparamos as extensões (relativas ou absolutas) das Constituições Estaduais, há forte indício estatístico de que não são diferentes. Isso corrobora o encontrado na comparação entre os Títulos, já que aparentemente o fato de ser uma constituição de um Estado ou outro não altera significativamente a estrutura da Constituição e a proporção que seus Títulos ocupam, logo, a extensão total. O Gráfico 2.11 exibe a proporção dos Títulos em cada Constituição Estadual.

\footnotetext{
${ }^{41}$ No total são 325 pares únicos.

42 Dos 325 pares interestaduais. Apenas 4 correlações não são significativas a $5 \%$. Dos valores significativos, a menor correlação é de 0,7 e a maior de 0,996, sendo a média de 0,9.
} 


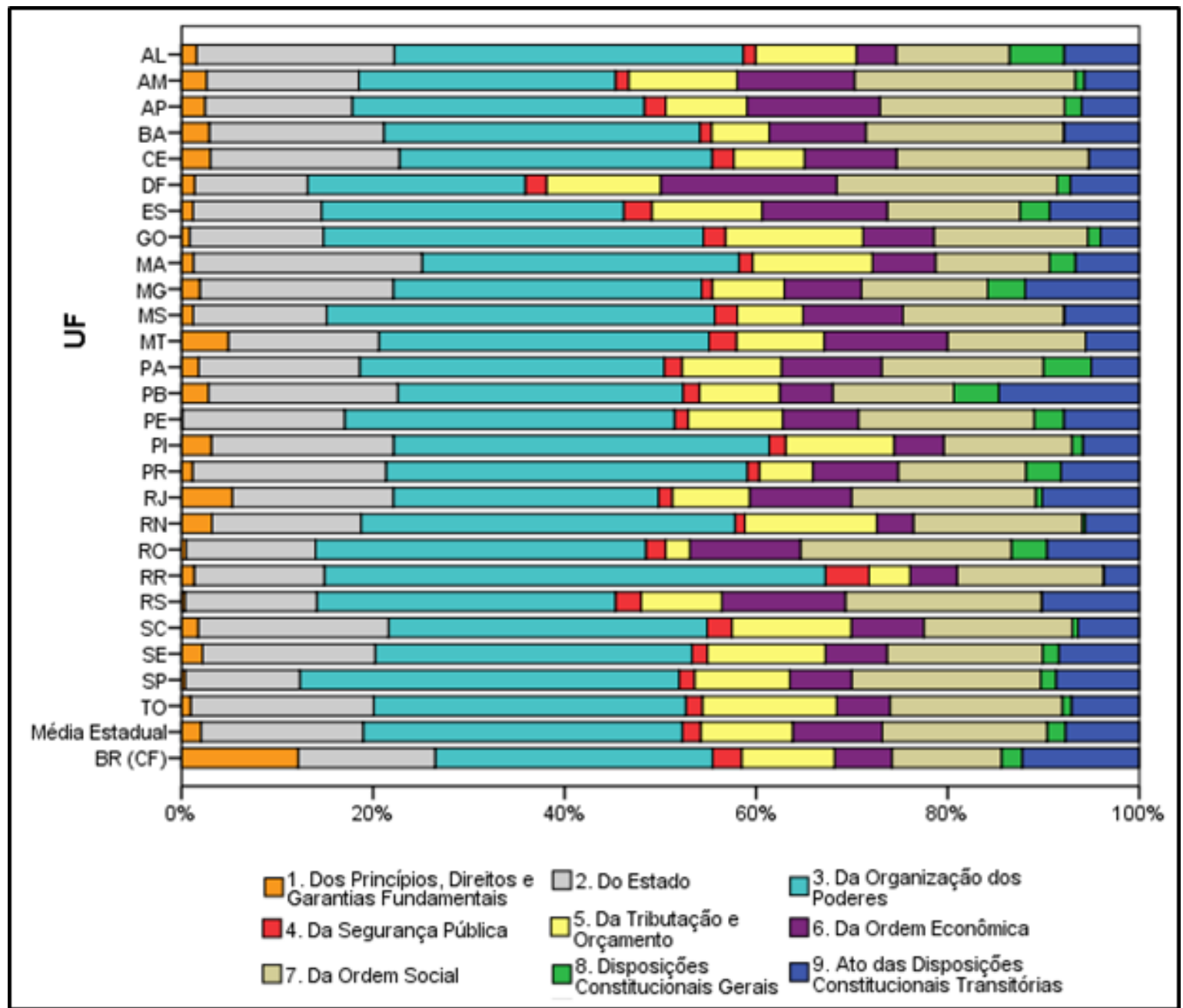

Gráfico 2.11 - Composição relativa das Constituições Estaduais, Constituição Federal e Constituição Estadual Média

Do Gráfico 2.11 podemos notar que a composição relativa da Constituição dos estados brasileiros se mostra relativamente constante. Análogo ao encontrado anteriormente. Ou seja, independente do Estado em questão e da extensão absoluta, as Constituições Estaduais seguem um padrão, seus Títulos, ou os temas que abordam, são relativamente constantes. A participação que cada Título possui nas Constituições é semelhante também no caso da CF, salvo pelo Título 1, que como vemos é significativamente maior nesta.

Aproximadamente metade dos dispositivos de cada Constituição é dedicada à organização dos poderes e organização do Estado. Já os Princípios, Direitos e 
Garantias Fundamentais, juntamente com a Segurança Pública e as Disposições Constitucionais Gerais representam fração mínima da distribuição de dispositivos nos estados. O único Título que não foi encontrado em todas as Cartas foi o Título 8 (Disposições Gerais ${ }^{43}$ ). Os cinco estados que não contam com este Título são Bahia, Ceará, Mato Grosso, Mato Grosso do Sul e Roraima.

Embora a composição proporcional das Constituições Estaduais apresente certa variabilidade, esta não é suficiente para afirmar que as Constituições Estaduais são estatisticamente distintas. Com a padronização das Constituições Estaduais e Constituição Federal vemos que a ideia de que são consideravelmente semelhantes se sustenta. Quando avaliamos a distribuição de dispositivos de cada Título por Estado há indícios de que os Títulos se organizam em quatro blocos consideravelmente distintos entre si. No entanto, dentro de cada bloco não há indícios de que os Títulos se organizam de forma distinta, ademais, há divisão clara de extensão entre eles. Então não só as Constituições Estaduais possuem composição proporcional semelhante, mas esta também é significativamente próxima da composição da Constituição Federal.

Contudo Roraima e Distrito Federal fogem à regra. Estes apresentam estruturas consideravelmente diferentes. No caso de Roraima, não só possui a menor Constituição em termos absolutos, como apresenta composição relativa estatisticamente distinta das demais. Mesmo que o Título 3 de Roraima seja o menor entre os Estados (319 dispositivos), concentra 52\% dos dispositivos de sua Carta, fração acima da média estadual ${ }^{44}$. Em contrapartida seu Título 6 se encontra entre os menores e contém apenas $4,5 \%$ de seus dispositivos (30 dispositivos). Já o Distrito Federal, embora haja forte indício estatístico de que não é distinto das demais Constituições Estaduais, é o caso contrário de Roraima. Isto é, o Distrito Federal se situa entre as Constituições mais extensas e possui, proporcionalmente, o menor Título $3(22,1 \%)$ e o maior Título 6 (18,36\%).

\footnotetext{
${ }^{43}$ As "Disposições Gerais" tem por objetivo reunir preceitos que são comuns a mais de um Título, Capítulo ou Seção, preceitos autônomos que não se encaixam nas divisões do texto em virtude da falta de pertinência temática ou então reúnem regras aplicáveis à toda a Constituição (MINAS GERAIS, 2013).

${ }^{44} \mathrm{O}$ segundo maior Título 3, enquanto proporção, concentra 40,3\% dos dispositivos.
} 
Além da existência de blocos que concentram Títulos cujas características e extensão são similares, também encontramos efeito consideravelmente forte sobre a quantidade de dispositivos. Isto é, a variação no Título parece explicar boa parte da variação na quantidade de dispositivos de uma observação, lembrando que nesta situação uma observação é um conjunto de dispositivos ${ }^{45}$ com tema semelhante e pertencentes a um estado específico. Consequentemente há indícios de que a variável estado não altera significativamente a quantidade de dispositivos. Ou seja, a quantidade de dispositivos incidente sobre um título possui associação mais intensa com a variação no Título do que na Unidade Federativa. De outra forma, a quantidade de normas elevadas a nível constitucional, por diferentes constituintes, sobre um tema em comum, possui mais associação com o tema que é tratado do que com as próprias características dos constituintes, das assembleias ou outras variáveis que são covariadas com as unidades federativas.

A divisão proporcional de temas nas Cartas Estaduais também é consideravelmente semelhante à disposição de temas na Constituição Federal, mesmo que esta seja mais extensa do que a média estadual e possua algumas diferenças na proporção de temas tratados. Nota-se que as distinções mais significativas se encontram na extensão dos Títulos: 1 Dos Princípios, Direitos e Garantias Fundamentais; 3. Da Organização dos Poderes e 9. ADCT.

Além de captar a semelhança, e realçar diferenças, entre as Constituições Estaduais e Federal, a padronização dos Títulos, qual seja, organização dos temas tratados nos dispositivos constitucionais sob critério único, pode ser utilizada para descrever o processo de alteração constitucional.

\footnotetext{
${ }^{45}$ Derivado da contagem de observações no banco principal.
} 


\section{Emendamento constitucional nos estados}

\subsection{Regras de Alteração Constitucional}

A alteração constitucional não é um fenômeno único, mas um termo que pode configurar uma série de processos distintos. Alguns dos processos considerados como alteração constitucional são a alteração gradual na interpretação do texto constitucional, a alteração do próprio texto constitucional ou até mesmo a extinção e substituição de uma Constituição (ELKINS; GINSBURG; GIOVANONNI, 2003; MELTON, 2009; LUTZ, 1994, 2006; NEGRETTO, 2012; NORONHA, 2014; RASCH, 2008; VOIGT, 2009). Tendo em vista a grande abrangência do termo alteração constitucional, nosso foco será sobre um processo específico de mudança, o processo de emendamento constitucional identificado pela alteração no texto escrito das Cartas.

No caso dos estados Brasileiros as normas que balizam esse procedimento são definidas em nível constitucional e cada emenda, caso promulgada, torna-se parte integrante da constituição, já que passa a compor seu texto principal e/ou é adicionada ao final ${ }^{46}$ do documento. Muito embora a Constituição Federal de 1988 tenha determinado a obrigatoriedade da promulgação das Constituições estaduais, as regras de alteração Constitucional em cada Unidade Federativa não foram por ela determinadas ou mencionadas. Nesta não há provisões de como deve ser o processo de alteração nas Constituições Estaduais. A determinação das regras de Emendamento Constitucional ficou a critério de cada Estado.

Todos os Estados admitiram a possibilidade de emendamento da constituição. Em todos eles, a proposição de Emenda foi atribuída ao Governador e à Assembleia Legislativa, e em alguns estados essa prerrogativa também foi entregue à iniciativa popular e às câmaras municipais. Único estado a prever a participação do Judiciário, no Pará o Tribunal de Justiça possui capacidade de proposição de emendamento mediante aprovação da maioria dos Desembargadores. No que diz respeito à proposição por parte das Assembleias Legislativas, as constituições estabelecem um

\footnotetext{
${ }^{46}$ Diferentemente da Constituição Federal em que há um padrão, nas Constituições Estaduais variam no que diz respeito à formalização do local reservado às emendas. Em algumas Cartas as emendas são integradas ao texto, em outra são acrescentadas ao final como apêndice e finalmente há aquelas que são apresentadas como documento distinto.
} 
mínimo de deputados que varia de 8 a 32 (1/3 a 2/3 dos deputados). Da mesma forma, para aprovação da proposta de emenda, as constituições exigem maiorias de 14 a 57 (3/5 a 2/3). A Tabela 3.1 exibe as regras e quantidades de deputados necessárias à proposição e aprovação de Emendas Constitucionais. Como do total de emendas aprovadas apenas duas ${ }^{47}$ não foram de autoria das Assembleias ou Governadores, optamos por omitir as demais regras de proposição de cada Estado.

Tabela 3.1 - Regras de Proposição e Aprovação de Emendas às Constituições Estaduais

\begin{tabular}{|c|c|c|c|c|c|}
\hline \multirow[b]{2}{*}{ UF } & \multirow[b]{2}{*}{$\begin{array}{l}\text { Tamanho da } \\
\text { Assembleia }\end{array}$} & \multicolumn{2}{|c|}{ Proposição de EC } & \multicolumn{2}{|c|}{ Aprovação de EC } \\
\hline & & Regra & $\begin{array}{l}\text { Número de } \\
\text { Deputados }\end{array}$ & Regra & $\begin{array}{l}\text { Número de } \\
\text { Deputados }\end{array}$ \\
\hline AL & 27 & $1 / 3$ & 9 & $3 / 5$ & 17 \\
\hline AM & 24 & $1 / 3$ & 8 & $3 / 5$ & 15 \\
\hline AP & 22 & $1 / 3$ & 8 & $3 / 5$ & 14 \\
\hline BA & 63 & $1 / 3$ & 21 & $3 / 5$ & 38 \\
\hline CE & 46 & $1 / 3$ & 16 & $3 / 5$ & 28 \\
\hline DF & 24 & $1 / 3$ & 8 & $2 / 3$ & $16\left(15^{\star}\right)$ \\
\hline ES & 30 & $1 / 3$ & 10 & $3 / 5$ & 18 \\
\hline GO & 41 & $1 / 3$ & 14 & $3 / 5$ & 25 \\
\hline MA & 42 & $1 / 3$ & 14 & $3 / 5$ & 26 \\
\hline MG & 78 & $1 / 3$ & 26 & $3 / 5$ & 47 \\
\hline MS & 24 & $1 / 3$ & 8 & $2 / 3$ & $16\left(15^{\star}\right)$ \\
\hline MT & 24 & $1 / 3$ & 8 & $3 / 5$ & 15 \\
\hline PA & 41 & $1 / 3$ & 14 & $3 / 5$ & 25 \\
\hline PB & 36 & $1 / 3$ & 12 & $3 / 5$ & 22 \\
\hline PE & 49 & $1 / 3$ & 17 & $3 / 5$ & 30 \\
\hline PI & 30 & $1 / 3$ & 10 & $3 / 5$ & 18 \\
\hline PR & 54 & $1 / 3$ & 18 & $3 / 5$ & 33 \\
\hline $\mathbf{R J}$ & 71 & $1 / 3$ & 24 & $3 / 5$ & 43 \\
\hline RN & 24 & $1 / 3$ & 8 & $3 / 5$ & 15 \\
\hline RO & 24 & $1 / 3$ & 8 & $2 / 3$ & $16\left(15^{\star}\right)$ \\
\hline RR & 24 & $2 / 3$ & $16\left(8^{*}\right)$ & $3 / 5$ & 15 \\
\hline RS & 55 & $1 / 3$ & 19 & $3 / 5$ & 33 \\
\hline SC & 40 & $1 / 3$ & 14 & $3 / 5$ & 24 \\
\hline SE & 24 & $1 / 3$ & 8 & $3 / 5$ & 15 \\
\hline SP & 94 & $1 / 3$ & 32 & $3 / 5$ & 57 \\
\hline TO & 25 & $1 / 3$ & 9 & $2 / 3$ & $17\left(15^{\star}\right)$ \\
\hline
\end{tabular}

* Número de Deputados caso a regra predominante de $1 / 3$ fosse a vigente também nestes estados.

\footnotetext{
${ }^{47}$ Emenda de número 36 do Amapá foi proposta por iniciativa popular, e a de número 4, do Mato Grosso é originária das Câmaras Municipais.
} 
Para a proposição de emendas apenas Roraima diferia dos demais estados. Enquanto predominava no país a necessidade de $1 / 3$ dos membros da Assembleia Legislativa, Roraima estabelecia um mínimo mais elevado de 2/3, número paradoxalmente superior ao fixado para a sua aprovação. Com a EC 17, Roraima corrigiu a regra de proposição para 1/3 dos membros da Assembleia e, assim, a partir de 2006 a regra de proposição de emendas pelos legislativos se torna uniforme em todos os estados.

Quanto à aprovação, a regra predominante é que a proposta obtenha voto favorável, em dois turnos, de no mínimo 3/5 dos membros da Assembleia. Apenas quatro estados utilizam o critério de 2/3: Distrito Federal, Mato Grosso do Sul, Rondônia e Tocantins. No entanto quando consideramos o número de votos (ou membros) favoráveis, vemos que a regra mais exigente de $2 / 3$ produz efeito apenas marginal. Nos três primeiros estados, a exigência de 2/3 em comparação com 3/5 eleva em apenas 1 voto - ou 4,2\% do total de votos possíveis - o quórum de aprovação ao passo que no Tocantins a diferença é de 2 votos - que corresponde a $8,4 \%$ dos votos possíveis. Portanto, guardadas essas pequenas diferenças, temos que as regras de proposição e aprovação das Emendas Constitucionais nos Estados são praticamente as mesmas.

Ademais, quando comparamos os trechos das Constituições que especificam o Processo Legislativo encontramos textos muito próximos não só em conteúdo, mas na escrita. Em todos os estados a descrição do que compreende o processo legislativo é exposto em um artigo, seguido de uma subseção que determina as condições do emendamento. Quando comparados aos pares, a proporção média de frases idênticas compostas por cinco palavras (excluídos os artigos e preposições) é de $80 \%$. Ou seja, ao decompor os trechos em frases de 5 palavras, 8 em cada 10 são encontradas, de forma idêntica, no par avaliado. A forma mais comumente encontrada foi:

Art. X. - O processo legislativo compreende a elaboração de:

I - emendas à Constituição;

II - leis complementares;

III - leis ordinárias; 
IV - Leis delegadas;

$\mathrm{V}$ - decretos legislativos;

$\mathrm{VI}-$ resoluções.

Art. Y - A Constituição poderá ser emendada mediante proposta:

I - de um terço, no mínimo, dos membros da Assembleia Legislativa;

II - do Governador do Estado;

III - de mais [...] das Câmaras Municipais do Estado;

$\S 1^{\circ}$ - A Constituição não poderá ser emendada na vigência de intervenção federal, de estado de defesa ou estado de sítio.

$\S 2^{\circ}$ - A proposta será discutida e votada em dois turnos, considerando-se aprovada quando obtiver, em ambas as votações voto favorável de [...] dos membros da Assembleia Legislativa.

$\S 3^{\circ}$ - A emenda à Constituição será promulgada pela Mesa da Assembleia Legislativa, com o respectivo número de ordem.

$\S 4^{\circ}$ - A matéria constante da proposta de emenda rejeitada ou havida por prejudicada não pode ser objeto de nova proposta na mesma sessão legislativa;

Muito embora o número dos artigos em questão mude, em todos os Estados são sequenciais e mesmo a ordem dos incisos e parágrafos de cada artigo não difere muito. Além da ordem também observamos que a própria redação é semelhante. Em diversos casos há reprodução ipsis literis, e mesmo quando não são idênticos verificamos a utilização de sinônimos ou a mera inversão da ordem do discurso. O caput do Art. X é escrito de forma idêntica nas 26 Constituições 
levantadas, bem como seus três primeiros incisos. O Art. Y segue também o mesmo padrão, as diferenças são encontradas nos poucos casos em que as regras de aprovação diferem. Assim não só as regras de proposição e aprovação de Emendas entre os Estados são semelhantes, mas o próprio trecho que dispões acerca de tais normas é escrito de forma semelhante, se não idêntico.

A mesma organização é encontrada nos artigos 59 e 60 da Constituição Federal de 1988, ocorrendo apenas a transposição de termos federais para estaduais (de Presidente da República para Governador). Se na União a aprovação necessária é de três quintos nas duas casas legislativas, nos Estados, com legislativo unicameral, são necessários três quintos em dois turnos na mesma casa. Muito embora existam diferenças nas regras de proposição e aprovação de emendas nos Estados e na União, estas são consideravelmente semelhantes.

Se por um lado os estados apresentam alguma diversidade nas regras de proposição em virtude das diferentes regras referentes à iniciativa popular, câmaras municipais e até mesmo Tribunal de Justiça, por outro, tal diversidade se limita ao plano normativo quando consideramos a quantidade de alterações constitucionais com tais origens. Assim as regras de proposição que se mostram relevantes são as pertinentes ao poder Executivo e Assembleia Legislativa, uniformes entre os estados. Então não só as regras de proposição são semelhantes entre os Estados, mas também se aproximam, guardadas as devidas proporções, das regras de alteração da Constituição Federal. Quanto às regras de aprovação, mesmo que quatro estados sejam mais exigentes, quando o número de membros necessários à aprovação é considerado, a diferença se torna marginal e observamos regras análogas às de aprovação de emendas no plano federal.

\subsection{Quantificação do Emendamento Constitucional}

A fim de avaliar a extensão do emendamento constitucional apresentado pelos estados brasileiros levantamos as emendas aprovadas - e publicadas pela imprensa oficial de cada estado - desde a promulgação da Constituição Estadual até o dia 31 de Dezembro de 2014. O primeiro estado a alterar sua Constituição foi o Maranhão, com a promulgação de sua primeira emenda em 11 de Dezembro de 1989, 
apenas 67 dias após a promulgação de sua Constituição. O dia 22 de Dezembro de 2014 contém as últimas emendas promulgadas no período recortado ${ }^{48}$.

Assim como a extensão de uma Constituição, o emendamento constitucional também pode ser mensurado por diferentes métodos. A forma mais imediata de quantificar o emendamento constitucional é por meio da contagem do número de emendas promulgadas. Sendo a emenda constitucional, promulgada, o meio pelo qual a alteração constitucional será avaliada, os diferentes métodos de medir a extensão do emendamento têm como ponto em comum a emenda promulgada. Portanto o primeiro levantamento relevante diz respeito à quantidade de emendas promulgadas em cada unidade federativa. Sempre que se mostrar pertinente, incluiremos os dados relativos ao emendamento da constituição federal, para efeitos comparativos.

A Tabela 3.2 apresenta o total de emendas constitucionais aprovadas em cada uma das 26 unidades federativas estudadas e o Gráfico 3.1 dispõe o número de emendas promulgadas por estado, em ordem crescente. Ambos incluem também a informação sobre o emendamento federal.

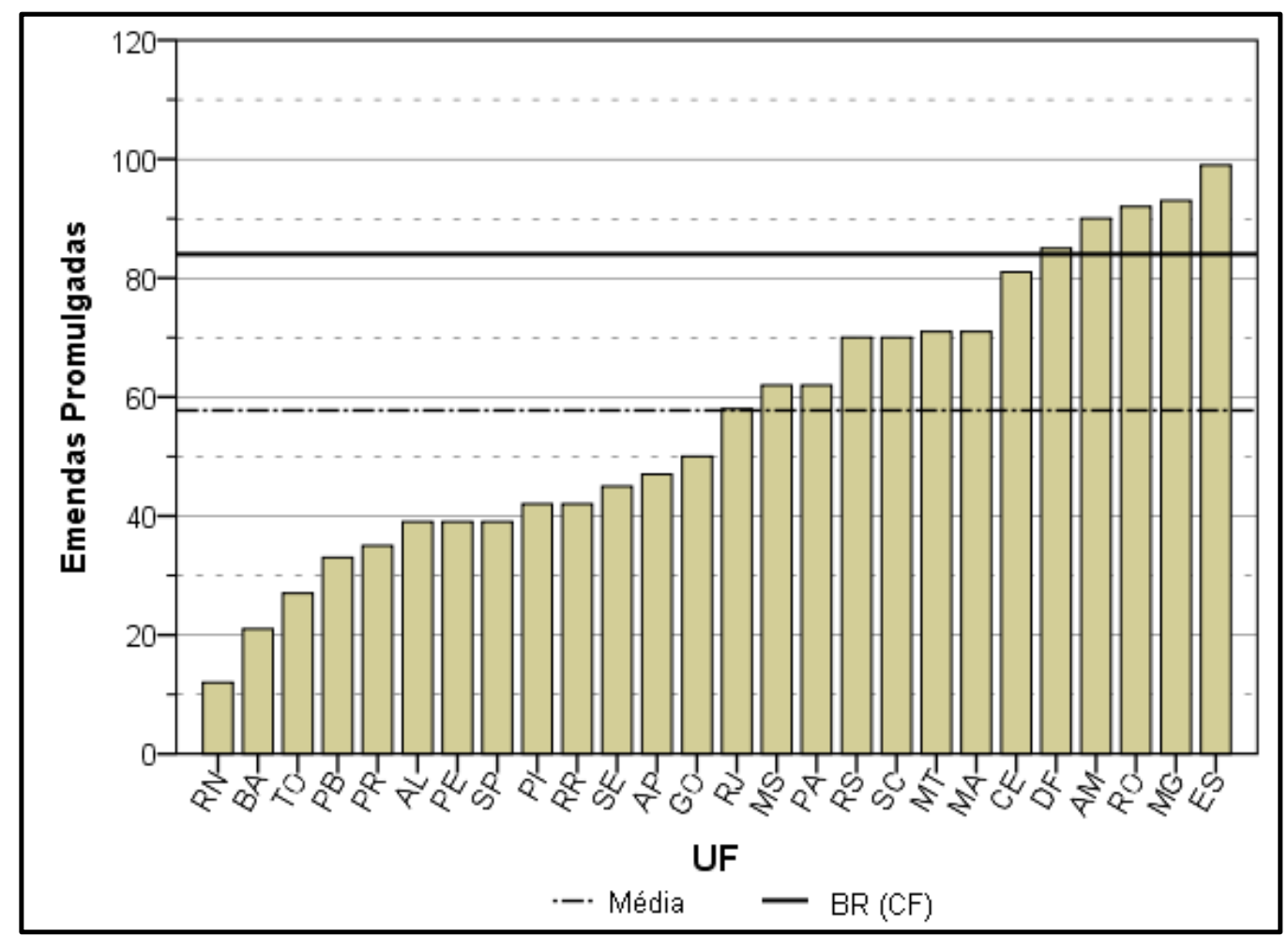

Gráfico 3.1 - Total de Emendas Promulgadas por UF

${ }^{48}$ No dia 22/12/2014 o Maranhão promulga duas emendas e o Amazonas três. 
Tabela 3.2 -Tamanho do Emendamento por Unidade Federativa (1989-2014)

\begin{tabular}{cc}
\hline UF & Número de Emendas \\
\hline AL & 39 \\
AM & 90 \\
AP & 47 \\
BA & 21 \\
CE & 81 \\
DF & 85 \\
ES & 99 \\
GO & 50 \\
MA & 71 \\
MG & 93 \\
MS & 62 \\
MT & 71 \\
PA & 62 \\
PB & 33 \\
PE & 39 \\
PI & 42 \\
PR & 35 \\
RJ & 58 \\
RN & 12 \\
RO & 92 \\
RR & 42 \\
RS & 70 \\
SC & 70 \\
SE & 45 \\
SP & 39 \\
TO & 27 \\
BR (CF) & 84 \\
\hline
\end{tabular}

${ }^{*}$ As Emendas de Revisão da CF não foram consideradas

O Estado que conta com maior número de Emendas aprovadas no período avaliado é o Espírito Santo, com 99 Emendas. A constituição do Rio Grande do Norte é a menos emendada com apenas 12 alterações. Os estados apresentaram média de 57 emendas aprovadas e dispersão consideravelmente elevada, evidenciada pelo coeficiente de variação de $42 \%$. Por outro lado, metade dos estados promulgou entre 38 e 70 (inclusive) emendas, representado pelo intervalo entre Alagoas e Santa Catarina, o que demonstra considerável simetria na distribuição. Então, mesmo que o total de emendas aprovadas em cada estado varie significativamente, a distribuição é consideravelmente simétrica, suave, e não apresenta valores discrepantes, mesmo 
que o Espírito Santo tenha aprovado cerca de oito vezes mais emendas que o Rio Grande do Norte.

Quando comparamos com a quantidade de emendas à Constituição Federal promulgadas vemos que a União promulga consideravelmente mais emendas do que a média estadual. A média de emendas promulgadas pelos estados representa $68 \%$ do total de emendas promulgadas pela União. Mesmo que cinco estados ${ }^{49}$ apresentem maior quantidade de emendas promulgadas no período, em número de emendas, a Constituição Federal é consideravelmente mais alterada.

Uma dimensão chave do emendamento constitucional é o horizonte temporal. Diferente das Constituições originais, o emendamento é um processo que envolve o tempo. Apenas o número de emendas promulgadas diz pouco sobre como de fato se deu, e qual a dimensão da alteração constitucional.

Associada a essa questão temporal, temos outra forma de quantificar o emendamento constitucional que é a taxa de emendamento. Esta unidade de medida, amplamente utilizada na literatura (ANCKAR; KARVONEN, 2002; ELKINS; GINSBURG; MELTON, 2009; LORENZ, 2005; LUTZ, 1994, 2006) consiste na média de emendas aprovadas em um intervalo de tempo. Usualmente a quantidade de emendas é instrumentalizada pela contagem do número de emendas aprovadas e a variável tempo é medida em anos. Com isso esta taxa de emendamento visa captar a magnitude da alteração constitucional relativizada pelo tempo decorrido.

Já Negretto (2012) utiliza outro critério a fim de quantificar o emendamento. No método utilizado pelo autor, consideramos não o número de emendas aprovadas por ano, mas o fato de haver ou não pelo menos uma emenda aprovada no ano. Isto é, nesta unidade de medida a taxa de emendamento é a média de anos em que é possível encontrar pelo menos uma emenda aprovada. Sendo assim a taxa utilizada por este autor varia de 0 a 1

A taxa de emendamento é um conceito utilizado pela literatura que tem por objetivo mensurar a intensidade da alteração constitucional, mais especificamente do emendamento. Segundo os critérios descritos é de se esperar que quanto maior a

\footnotetext{
${ }^{49}$ São eles o Distrito Federal (85), o Amazonas (90), Rondônia (92), Minas Gerais (93) e Espírito Santo (99).
} 
taxa de emendamento - seja ela a média de emendas anuais ou a média de anos em que há emendamento - mais a constituição em questão foi alterada, diga-se, emendada. No entanto, a utilização de ambas abordagens para o caso da alteração constitucional nas constituições estaduais brasileiras é prejudicada.

O poder comparativo da média de emendas aprovadas ao ano para a comparação entre os estados brasileiros é reduzido em razão da promulgação simultânea $^{50}$ (se considerarmos ano como unidade de tempo) de 23 das 26 Constituições avaliadas. Ao utilizar esta taxa acrescentamos pouca ou nenhuma informação para a comparação entre os estados. A única diferença significativa é no Distrito Federal, que muda de quinto maior emendamento, quando o total de emendas aprovadas é considerado, para maior emendamento, quando a média anual é utilizada. Além da questão numérica a utilização da média de emendas ao ano suscita um problema teórico para nosso objetivo.

Ao utilizarmos o número de emendas aprovadas, seja em números absolutos ou relativizado por um intervalo temporal, o que medimos não é exatamente a magnitude da alteração constitucional. Não medimos se um texto constitucional foi muito ou pouco alterado, mas sim o número de vezes em que as barreiras impostas pelas regras de alteração constitucional foram superadas. Isto é, ao utilizar o número de emendas aprovadas como indicativo do emendamento, a ênfase analítica recai sobre os custos políticos da alteração constitucional, e não sobre a alteração em si (NORONHA, 2014).

Na mesma linha, a taxa de emendamento utilizada por Negretto (2012), ou a média de anos em que se observa emendamento, também chamada de taxa de emendamento agregado, não indica de fato quanto ou como uma Constituição foi alterada, mas sim em quantos anos ocorreu emendamento. Esta taxa não capta a intensidade do emendamento ao não fazer distinção entre um emendamento ou diversos, caso ocorram no mesmo ano. Por exemplo, em 2007 Rondônia promulga 17 emendas constitucionais e Goiás promulga apenas duas; por este método, ambas constituições são consideradas emendadas neste ano, portanto, atribui-se o valor 1 . Ao replicar o método para todos os anos e calcular a média, o valor encontrado para

\footnotetext{
${ }^{50}$ Amapá e Roraima possuem intervalo temporal de 23 anos, Distrito Federal de 21 anos e os demais estados de 25 anos.
} 
a taxa de emendamento agregado para ambos os estados é de 0,88 , mesmo que o primeiro tenha promulgado 92 emendas e o segundo 50.

Se nosso objetivo é quantificar a alteração constitucional, as taxas de emendamento apresentadas não são as unidades de medida mais adequadas. Sabendo que o emendamento é um processo em que o horizonte temporal é fundamental, o problema da utilização dos métodos acima deixa de ser apenas a variável tempo e passa a outra variável que estes têm em comum: a contagem de emendas constitucionais. Segundo Rasch (2008) a quantificação da variável emenda é problemática pois o que se entende por emenda constitucional não é trivial, dependerá da estrutura constitucional e legal em questão. Se compreendermos por uma emenda constitucional aquela que foi promulgada e numerada oficialmente, cuja contagem para os estados brasileiros encontra-se na Tabela 3.2 a alteração constitucional será captada de forma distorcida. O problema é que, ao contar as emendas, essas consideradas como equivalentes, quaisquer duas emendas serão contabilizadas de forma idêntica, sem que a importância, o conteúdo e a extensão da própria emenda sejam considerados.

\subsubsection{Estrutura das emendas}

A fim de avaliar a extensão do emendamento é necessário captar a extensão de cada uma das emendas. Para que a extensão de uma emenda seja avaliada, é necessário primeiro definir o que é pertinente incluir na mensuração. Muito embora inexista qualquer regra geral que determine a estrutura de uma emenda constitucional, é possível identificar uma estrutura comum semelhante à encontrada nas Emendas Constitucionais promulgadas pelo Congresso Nacional. O texto das emendas apresenta três grandes elementos constitutivos (BRASIL, 1999, 2002, 2004; MINAS GERAIS, 2013).

Inicialmente temos a parte preliminar (ou cabeçalho), composta pela epígrafe, ementa, preâmbulo e enunciado. A epígrafe indica a espécie da norma (Emenda à Constituição), o número e a data de promulgação. A ementa, além de oferecer um resumo claro e conciso da Emenda Constitucional, deve também indicar qual norma ou dispositivo será alvo da alteração, caso haja. O preâmbulo indica a instituição competente ao ato legal e a ordem de execução; no caso das Emendas às 
Constituições estaduais, a instituição será sempre a Assembleia Legislativa do estado em questão e a ordem de execução será a promulgação. Por fim, o enunciado compreende o objeto e o âmbito da norma, usualmente disposto no primeiro artigo da emenda.

Em seguida temos a parte normativa, composta pelo texto da norma em si. Da mesma forma que a Constituição original, o texto de uma emenda constitucional é dividido em artigos, parágrafos, incisos, alíneas e itens. Por fim temos a parte final (ou fecho), composta pelo local, data e nome do presidente, primeiro e segundo secretários da Assembleia Legislativa.

A partir deste modelo geral observado, a parte preliminar e a parte final não são relevantes à mensuração da emenda e consequentemente do emendamento. Muito embora disponham informações importantes, como o número da emenda e a data de promulgação, não contém o conteúdo em si da emenda, no máximo um

resumo contido na ementa. É a parte normativa das emendas que será mensurada. É nesta que encontramos a alteração constitucional de fato, o que é emendando e como é emendando.

$\mathrm{Na}$ maioria dos casos os artigos das emendas indicam qual alteração é efetuada, se as normas são modificadas, adicionadas ou revogadas e quais serão alvo da alteração. Em seguida, no caso de modificação, indicará o novo texto da norma constitucional, em caso de adição, a norma adicionada. Então, da mesma forma que uma Constituição possui elementos e partes que não são incluídas na mensuração, as emendas constitucionais também não serão medidas em sua integralidade, mas sim naquela parte que acreditamos que é relevante à alteração constitucional de fato.

3.2.2. Unidades de medida

A mensuração das emendas, com o objetivo de medir o emendamento constitucional, é análoga à mensuração da extensão da constituição original, portanto as mesmas unidades de medida serão consideradas. No caso do emendamento, a simples utilização do número de artigos como unidade de medida deve ser descartada. Na maioria das emendas promulgadas verificamos que são compostas 
por apenas um artigo, contendo o enunciado geral que indica quais alterações serão realizadas na constituição original. Poucas são as emendas que contém múltiplos artigos, e em três casos encontramos emendas que não discriminam artigo algum. Portanto a primeira unidade de medida discutida na mensuração constitucional não se mostra adequada nem viável para análise.

Como alternativa à contagem de artigos poderíamos contar as palavras. Ao contar as palavras presentes na parte normativa de cada emenda constitucional a ideia subjacente é semelhante à contagem de palavras no texto constitucional. Espera-se que ao contar o número de palavras presentes nas emendas constitucionais tenhamos noção de quanto emendamento foi realizado. Como vimos, uma das principais objeções a essa forma de mensuração é que ela dificulta a comparação de textos constitucionais produzidos em diferentes línguas, e o mesmo se poderia dizer da comparação de emendamentos. Embora essa crítica não se aplique ao caso das constituições estaduais - dada a sua homogeneidade linguística - o fato é que a contagem de palavras não é capaz de aferir as unidades de sentido do texto constitucional, tal como faz a técnica de mensuração por dispositivos.

$\mathrm{Na}$ literatura, é possível identificar autores que embora utilizem a contagem de palavras para a mensuração da extensão constitucional, não utilizam essa unidade de medida quando se referem ao emendamento (LORENZ, 2005; LUTZ, 1994, 2006; TSEBELIS; NARDI, 2014) e optam pela contagem de emendas promulgadas. Ao utilizarmos a contagem de palavras, o que conseguimos é apenas a mensuração da extensão do emendamento em termos textuais, não é possível captar o conteúdo ou quaisquer outros elementos relevantes a esse processo. Ademais, a contagem de palavras não permite que se faça discriminação do impacto do emendamento, grosso modo, se uma norma foi revogada, adicionada ou modificada. Assim, mesmo que a contagem de palavras possa ser utilizada como unidade de medida do emendamento constitucional, ao utilizá-la conseguimos apenas uma unidade de tamanho que não permite classificação qualitativa e análise do emendamento.

A terceira unidade de medida utilizada na mensuração da extensão das Constituições originais, a contagem de dispositivos, pode também ser utilizada para medir o emendamento. Da mesma forma que é possível decompor o texto das Constituições em dispositivos constitucionais, é possível decompor o texto das 
Emendas às Constituições em dispositivos de emenda constitucional. Na parte normativa das emendas é possível identificar não só os artigos e dispositivos que pertencem diretamente à emenda e indicam quais alterações serão realizadas, mas também aqueles que contém o texto da alteração constitucional em questão. Com isso é possível identificar não só quanto foi emendado, mas também o que foi emendado. O procedimento de decomposição das emendas em dispositivos é semelhante ao procedimento utilizado para decompor o texto constitucional em dispositivos e também é parte integrante da Metodologia de Análise Constitucional. A Tabela 3.3 apresenta a extensão do emendamento, em dispositivos, de cada Unidade Federativa e o Gráfico 3.2 dispõe os dados de forma crescente.

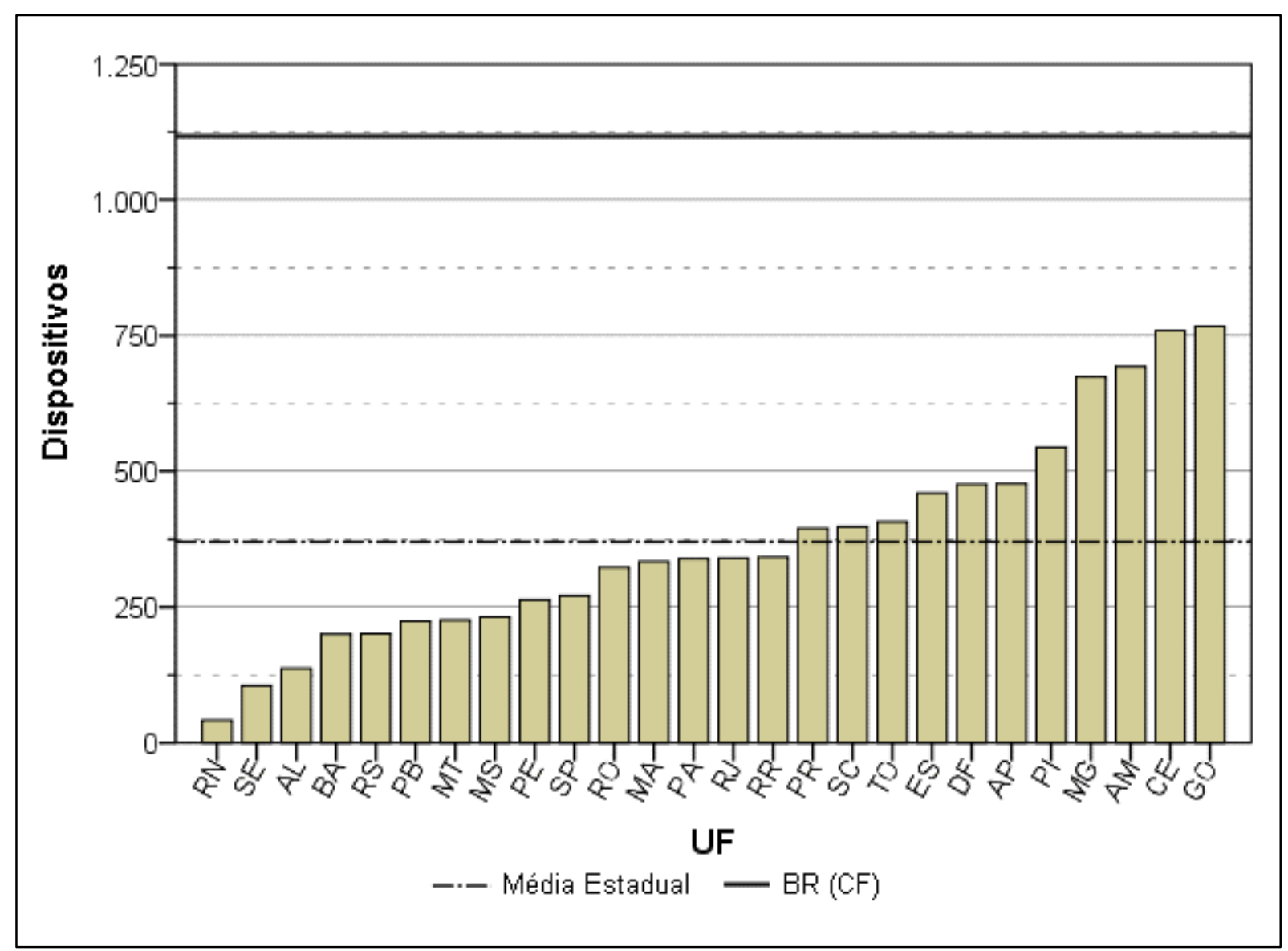

Gráfico 3.2 - Total de Dispositivos de Emenda Promulgados por UF 
Tabela 3.3 - Dispositivos de Emenda promulgados por Unidade Federativa (1989-2014)

\begin{tabular}{cc}
\hline UF & Total de Dispositivos \\
\hline AL & 137 \\
AM & 693 \\
AP & 477 \\
BA & 200 \\
CE & 759 \\
DF & 476 \\
ES & 460 \\
GO & 767 \\
MA & 334 \\
MG & 674 \\
MS & 232 \\
MT & 226 \\
PA & 339 \\
PB & 224 \\
PE & 263 \\
PI & 544 \\
PR & 395 \\
RJ & 340 \\
RN & 41 \\
RO & 323 \\
RR & 342 \\
RS & 201 \\
SC & 398 \\
SE & 105 \\
SP & 271 \\
TO & 407 \\
BR (CF) & 1117 \\
\hline
\end{tabular}

Do Gráfico 3.2 vemos que quando o emendamento é medido em quantidade de dispositivos há considerável dispersão. O estado que conta com maior quantidade de dispositivos é Goiás, com 767 dispositivos de EC promulgados, enquanto o menor emendamento pertence ao Rio Grande do Norte, com apenas 41 dispositivos de EC. No total os estados promulgaram 9.628 dispositivos de emenda, o que nos dá uma média de 370,3 dispositivos por estado e desvio padrão de 195. Com isso o coeficiente 
de variação é de $52 \%$, reiterando a intensidade da variabilidade no emendamento. A mediana encontrada é de 339,5 dispositivos, situada entre o Pará e Rio de Janeiro e metade dos estados possui uma diferença de menos 118 dispositivos emendados da mediana. Isto indica que o intervalo entre Pernambuco e Tocantins, inclusive, contém metade dos estados (de 222 a 456 dispositivos, cujo intervalo é de 236 dispositivos). Mesmo que Goiás tenha promulgado aproximadamente 19 vezes mais dispositivos que o Rio Grande do Norte, em razão da grande variabilidade encontrada, não encontramos valores discrepantes. Por fim, mas não menos importante, cabe destacar que nenhum estado apresentou emendamento em quantidade superior ao verificado no mesmo período ao federal.

A média de dispositivos promulgados pelos estados representa apenas $33 \%$ da magnitude do emendamento Federal. Ao compararmos os extremos, o Rio Grande do Norte promulga, aproximadamente, 27 vezes menos dispositivos de emenda que a União. Enquanto Goiás, que apresenta o maior emendamento estadual, promulga pouco mais que a metade dos dispositivos de emendas à Constituição Federal. Então, mesmo que em termos absolutos a quantidade de dispositivos de Emenda Constitucional promulgados nos estados apresente grande variabilidade, ao compararmos o emendamento estadual, seja pela média ou de forma individual, com o federal, este mostra-se claramente maior.

Ao decompor as emendas constitucionais em dispositivos de emenda, a magnitude do emendamento é mais fielmente medida uma vez que é possível observar de fato quantos dispositivos normativos foram alterados. Duas emendas, quando mensuradas em dispositivos, não necessariamente terão o mesmo tamanho, portanto, o impacto na magnitude do emendamento pode ser discriminado. Enquanto a maior emenda encontrada apresentou 551 dispositivos ${ }^{51}$, a menor contém apenas 1. O Gráfico 3.3 permite observar como a utilização do número de emendas promulgadas não indica de fato a dimensão da alteração constitucional.

\footnotetext{
51 Emenda Constitucional 46 de Goiás. Esta emenda, promulgada em 2010, representa $72 \%$ de todo o emendamento do estado. Com seus 551 dispositivos é maior que o emendamento total de 22 dos 26 estados. Esta incide sobre 143 dos 208 artigos encontrados na Constituição de Goiás. No entanto a emenda em si conta com apenas 7 artigos. Segundo a ementa o objetivo é "alterar a Constituição Estadual atualizando-a em conformidade com a Constituição da República” (GOIÁS, 1989)
} 


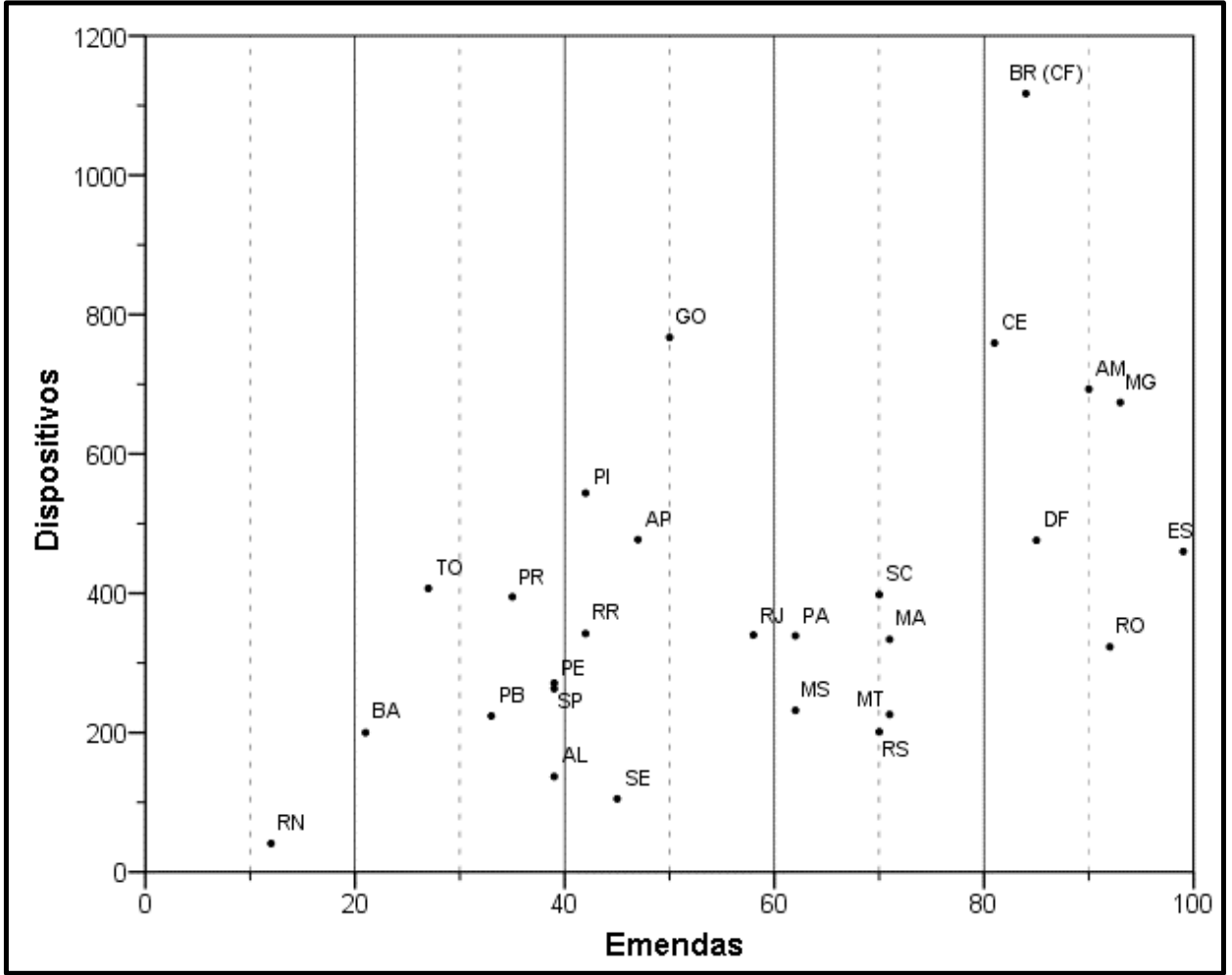

Gráfico 3.3 - Gráfico de Dispersão de Dispositivos x Emendas

Do gráfico, vemos que não necessariamente os estados que apresentaram maior quantidade de emendas promulgadas são aqueles que mais alteraram suas constituições em termos absolutos. Do Gráfico 3.3 vemos que, caso a quantidade de emendas seja utilizada como medida de tamanho do emendamento, pelos menos quatro estados e o Distrito Federal emendaram mais suas constituições do que a Constituição Federal foi alterada neste mesmo período. Todavia, se adotarmos o eixo dos dispositivos como medida, nenhum estado alcançou o patamar de emendamento do nível federal. Outro exemplo é que enquanto Rondônia promulgou 92 emendas, Goiás promulgou 50, o que poderia sugerir que o emendamento daquele foi cerca de duas vezes maior. Entretanto, após a contagem de dispositivos, vemos que ocorreu o inverso, o emendamento de Goiás foi pouco mais que o dobro do emendamento daquele. Então podemos afirmar que o número de emendas à constituição promulgadas não reflete a magnitude real da alteração constitucional.

A fim de melhor compreender o emendamento constitucional é necessário inserir o horizonte temporal. Ao longo do intervalo de 26 anos (1989 a 2014, inclusive), foram promulgados 9.628 dispositivos de emenda constitucional nos estados (1.475 
emendas) e 1.117 dispositivos de emenda à Constituição Federal (84 emendas). Em relação ao emendamento às Constituições Estaduais temos uma média de 370 dispositivos promulgados ao ano, ou 14 dispositivos promulgados ao ano por estado. A primeira emenda à Constituição Federal foi promulgada em 1992, portanto no intervalo de 23 anos temos uma média de 49 dispositivos de Emenda promulgados ao ano. Assim, no período analisado a Constituição Federal foi anualmente alterada, em média, cerca de quatro vezes a média anual da alteração estadual.

O Gráfico 3.4 apresenta o total de dispositivos promulgados em cada ano do intervalo, discriminando entre o total estadual e o federal. $O$ ano que observou maior número de dispositivos promulgados foi 1999, com 1.114 dispositivos promulgados nos estados, ou em média 43 dispositivos por estado. O menor emendamento é encontrado em 1989, com apenas 7 dispositivos promulgados. Como a promulgação da maioria das Constituições ocorreu nos últimos meses de 1989, era de se esperar menor emendamento neste ano. O desvio padrão é de 267 e o coeficiente de variação é de $72 \%$, ou seja, há variabilidade intensa na quantidade total de dispositivos promulgados entre os anos. Já no caso da União, o ano de 1998, com 217 dispositivos, foi o que observou maior emendamento enquanto no ano de 2008 há promulgação de apenas uma emenda que contém somente um dispositivo.

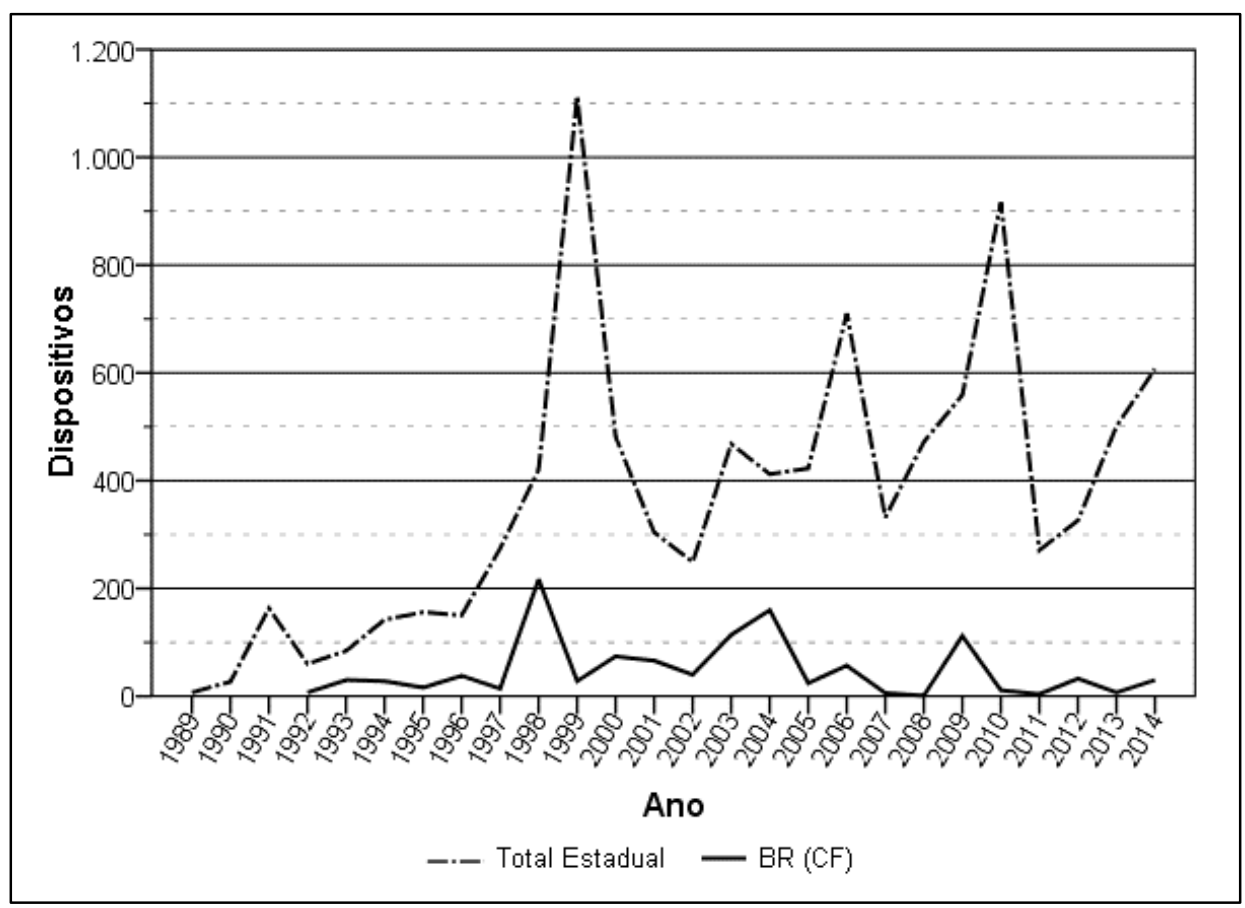

Gráfico 3.4 - Total de emendamento Estadual e Federal ao Ano 
Do Gráfico 3.4 também observamos a possibilidade de relação entre o emendamento estadual e o federal. Embora as magnitudes sejam distintas, já que uma retrata o coletivo do emendamento estadual e a outra apenas o emendamento federal, as linhas aparentam formatos semelhantes, especialmente nos picos. Ao observarmos 1998, 2004 e 2009, os anos com maior emendamento federal, podemos notar que os picos estaduais acompanham os mesmos, com apenas uma pequena defasagem no tempo de um ano nos casos de 1999 e 2010, e de dois no caso de 2006. De forma semelhante, quando observamos emendamento reduzido na Constituição Federal, em seguida também há emendamento reduzido no conjunto dos estados. Assim o Gráfico 3.4 sugere que pode haver alguma relação entre o emendamento Federal e o Estadual quando consideramos o horizonte temporal. No entanto isso não implica causalidade, isto é, não há evidência suficiente para afirmar que o emendamento federal causa o emendamento estadual nos anos seguintes.

No Gráfico 3.4 consideramos a soma dos dispositivos promulgados por todas as constituições estaduais em um mesmo ano, com isso o emendamento de cada estado não pode ser observado. Ao comparar o emendamento entre os estados em cada ano observamos variabilidade considerável. O Gráfico 3.5 apresenta a heterogeneidade que encontramos no emendamento de cada estado ao ano. 


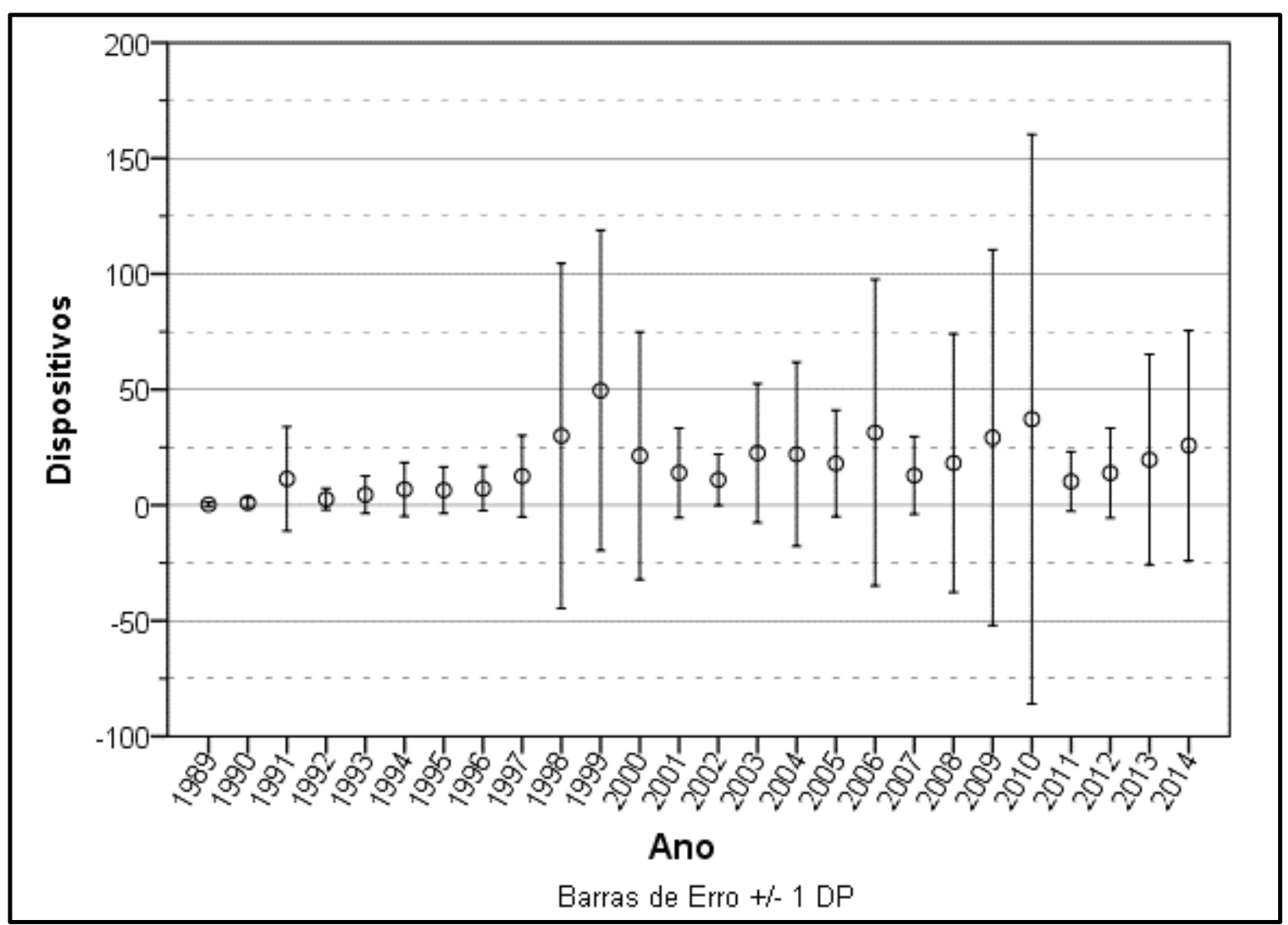

Gráfico 3.5 - Média de Dispositivos de Emenda Promulgados ao ano com um desvio padrão

Do Gráfico 3.5 vemos que não só o emendamento entre os anos é variado, mas ao considerar quanto cada estado emendou em cada ano observamos principalmente a heterogeneidade nas variações, isto é, há heteroscedasticidade no emendamento anual. O ano com maior variabilidade no emendamento é 2010; neste ano Goiás promulga 551 dispositivos e Minas Gerais 210, enquanto os demais estados somados apresentam apenas 155 dispositivos de emenda constitucional. Quando consideramos o emendamento por estado a maior variabilidade é encontrada em Goiás, que do total de seus 767 dispositivos emendados, 551 (EC 46) foram em 2010, enquanto o segundo ano em que este estado mais promulgou emendas foi 1997, com 50 dispositivos.

Assim vemos que, quando utilizamos a quantidade de dispositivos de emenda promulgados como unidade de medida o emendamento se mostra significativamente disperso, tanto nos estados quanto na União. Ao compararmos os anos também encontramos não só variabilidade elevada, mas inconstância na própria variação. Do Gráfico 3.4 há indícios de que o emendamento federal e o estadual 
apresentam alguma relação defasada temporalmente, esta só é aparente quando consideramos o conjunto dos estados. Ao agregar os estados desconsideramos a variabilidade existente, o que por um lado facilita a comparação e permite que a relação se torne evidente, por outro, ao desconsiderar a grande variação há possibilidade de incorrermos em erros de interpretação e de comparação quantitativa.

Ao decompor o emendamento por estado nos anos de 1999, 2006 e 2010 vemos que nos três casos são apenas alguns estados responsáveis pela maioria do emendamento anual. Em 1999 são 5 estados $^{52}$, em 2006 são apenas dois ${ }^{53}$ e em 2010 também dois, Goiás e Minas Gerais. Com isso podemos comparar então quais os temas abordados pelo emendamento destes casos e se houve emendamento Federal com tema semelhante nos anos anteriores.

Para o caso de 1999, grande parte do emendamento encontrado nos estados citados se deu por meio de uma grande emenda em cada um deles ${ }^{54}$. Ao levantar as ementas de tais emendas observamos que não só apontam para dois temas em comum, a Administração Pública e a Previdência Social, como em alguns casos é expresso na própria ementa que o objetivo é se adequar às mudanças na Constituição Federal promovidas pelas Emendas 19 e 20, que modificaram o regime e normas da Administração Pública e o sistema de previdência Social. Portanto, o elevado emendamento estadual observado em 1999 teve relação direta com o emendamento de 1998 na Constituição Federal.

A situação encontrada em 2006 é semelhante à de 2010. Nos dois anos não só o emendamento se concentra em apenas dois estados, mas também em uma emenda em cada ${ }^{55}$. No caso da EC 21 de São Paulo, promulgada em 2006, não só a ementa indica que as alterações tem o objetivo de adequar a Constituição Estadual às alterações na Constituição Federal, como na própria justificativa do projeto que deu origem a tal emenda o argumento é pela necessidade de atualizar a Constituição Estadual em face às alterações promovidas na Constituição Federal até então. Já na

\footnotetext{
${ }^{52}$ Amazonas, Bahia, Espírito Santo, Pará e Pernambuco promulgam conjuntamente 713 dos 1.114 dispositivos promulgados no ano.

53 Amapá e São Paulo são responsáveis por 433 dos 710.

${ }^{54}$ EC 26 no Amazonas, EC 07 na Bahia, EC 23 no Espírito Santo, EC 15 no Pará e EC 16 em Pernambuco.

${ }^{55}$ Em 2006 o emendamento se concentra na EC 35 no Amapá e EC 21 em São Paulo, em 2010 na EC 46 de Goiás e EC 84 de Minas Gerais.
} 
EC 35 do Amapá não há qualquer informação na ementa e não encontramos o projeto que deu origem a esta emenda. Tanto a ementa da EC 46 de Goiás, quanto da EC 84 de Minas Gerais, indicam que estas emendas têm por objetivo alterar a Constituição Estadual a fim de que sejam atualizadas em conformidade com as normas presentes na Constituição Federal.

Portanto, para os anos de 2006 e 2010 as ementas indicam que a alteração constitucional nos estados em questão teve por objetivo adequá-los às normas da Constituição Federal. No entanto, ao contrário da alteração constitucional de 1999, não há indícios claros de que esta alteração seja consequência do emendamento federal ocorrido no ano anterior, mas sim que a alteração é consequência do emendamento federal como um todo. De qualquer modo, se os casos analisados permitem afirmar a existência de vínculos entre o emendamento estadual e o federal, o fato é que permanece a pergunta sobre porque os demais estados não fizeram o mesmo, isto é, não atualizaram suas constituições em função de mudanças no plano federal, ou pelo menos não o fizeram no mesmo timing dos estados tomados aqui como exemplos.

\subsection{Classificação do Emendamento.}

Ao utilizarmos os dispositivos de emenda constitucional como unidade de medida do emendamento é possível não só mensurar o tamanho do emendamento de uma forma que nos parece mais apropriada, mas também permite que o emendamento seja classificado segundo outros critérios que não só sua extensão. Utilizamos três outras variáveis como critérios de classificação do emendamento a fim de identificar quais temas são mais frequentemente emendados, qual a natureza da alteração e qual a origem do emendamento por ator institucional.

\subsubsection{Emendamento por tema}


Usualmente, as emendas constitucionais alteram mais de um dispositivo da constituição original. Assim, é possível que uma mesma emenda aborde diversos temas. Com o objetivo de avaliar o tema dos dispositivos de emendamento, e com isso identificar quais temáticas são mais frequentemente alteradas, utilizamos o mesmo sistema de padronização de Títulos aplicados às Constituições originais. Com isso, como as emendas à Constituição usualmente incidem sobre dispositivos presentes na constituição original, com base na padronização realizada tornou-se possível identificar quanto cada Título foi emendado ao longo do período. O Gráfico 3.6 indica a quantidade de dispositivos promulgados que incidiram sobre cada Título encontrado nas Constituições Originais após a padronização.

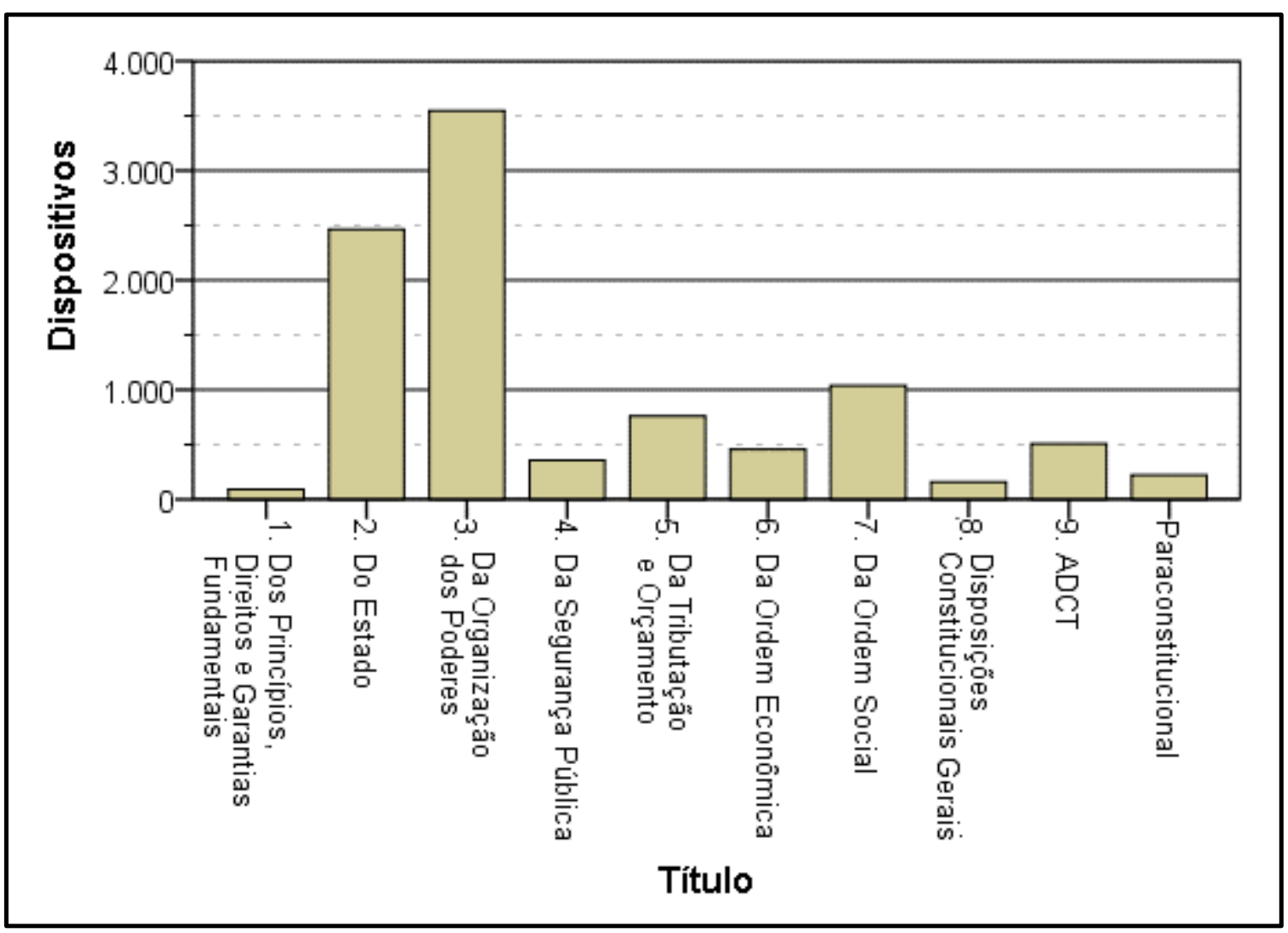

Gráfico 3.6 - Total de Dispositivos de Emenda Estadual por Título Padronizado

Além dos nove Títulos identificados nos textos originais, encontramos também outros dois tipos de emendamento que não se encaixam em nenhum deles. Os dispositivos de Renomeação, embora pouco frequentes, são dispositivos Constitucionais que renomearam Títulos, Capítulos ou Seções das Constituições Originais. Em virtude de sua frequência reduzida bem como de sua característica marginal na alteração Constitucional, serão desconsiderados nas análises 
subsequentes. O outro Título encontrado, denominado de Paraconstitucional, contém dispositivos de emenda constitucional que não integram formalmente 0 texto constitucional. Este tipo de dispositivo, identificado por Arantes e Couto (2009), tem como característica marcante o fato não serem incorporados formalmente ao texto constitucional e não emendarem nenhum dispositivo Constitucional preexistente, no máximo mencionam, regulam ou expandem outras matérias já tratadas na Constituição. Um exemplo de dispositivo paraconstitucional é o Artigo $2^{\circ}$ da EC 27 do Ceará:

"Art. $2^{\circ}$. As contas gerais e de gestão do Tribunal de Contas do Estado, referentes ao exercício dos últimos cinco anos, deverão ser encaminhados à Assembleia Legislativa imediatamente após a entrada em vigor da presente Emenda Constitucional." (CEARÁ, 1989).

Os Títulos com maior frequência de emendamento foram o Título 2 e o Título 3, respectivamente com 2.465 e 3.546 dispositivos de emenda. A média de dispositivos por Título foi de 875 e o desvio padrão de 1.221, com isso o coeficiente de variação é de $128 \%$, o que indica a extrema variabilidade no emendamento por Título. Em virtude da magnitude do emendamento dos Títulos 2 e 3, o Gráfico 3.6 é distorcido e sugere que dentre os demais Títulos há certa semelhança na quantidade de dispositivos de emenda, no entanto, a utilização de escala logarítmica ou mesmo medidas de dispersão para estes Títulos aponta a presença de variabilidade intensa. Portanto, por mais que os dois Títulos mais emendados gerem distorção, independentemente de seu emendamento elevado, os demais Títulos também são emendados em quantidades consideravelmente variadas. 


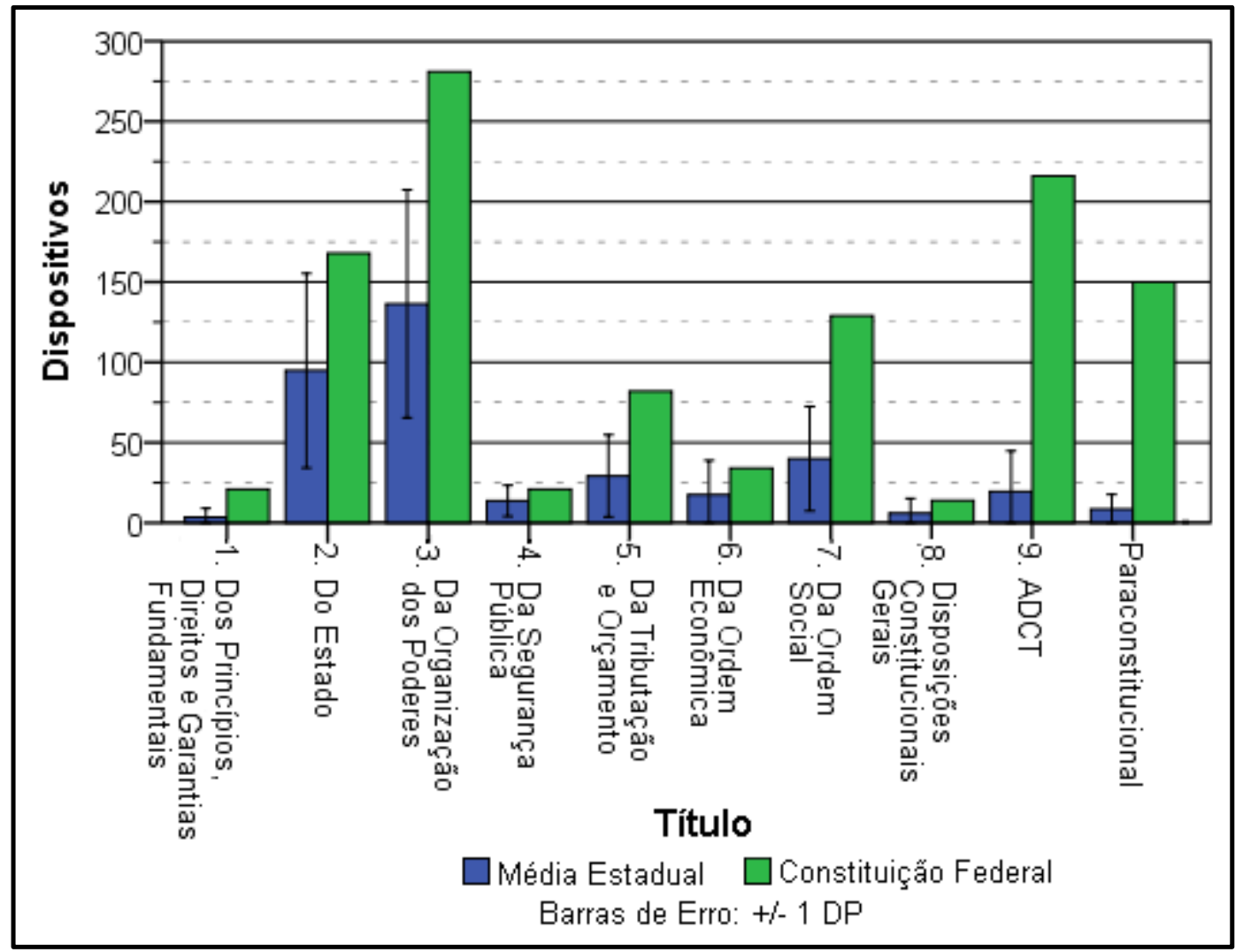

Gráfico 3.7 - Dispositivos por Título, Média Estadual e Total Federal

Do Gráfico 3.7 vemos que a dispersão no emendamento dos Títulos é mais intensa nos Títulos 2 e 3 mas apenas se considerarmos os valores absolutos. Ao considerarmos a dispersão relativa, o Títulos 2 e 3 são os que apresentam menores coeficientes de variação. Isso se observa em razão da própria intensidade do emendamento nos Títulos 2 e 3, já que juntos representam mais de $3 / 5$ do emendamento observado nos estados e todos os estados promulgaram dispositivos de emenda em tais Títulos, o que não ocorre nos demais. Então não só os Títulos são emendados de forma variável, mas tal variação também não é equivalente entre eles.

O Gráfico 3.7 também permite a comparação do emendamento por Título nos estados e na União. O emendamento médio nas Constituições Estaduais é menor que o da Constituição Federal em todos os Títulos, e os Títulos 2 e 3 também sofrem emendamento elevado na Constituição Federal. No entanto notamos diferença significativa no ADCT e nos dispositivos Paraconstitucionais. 


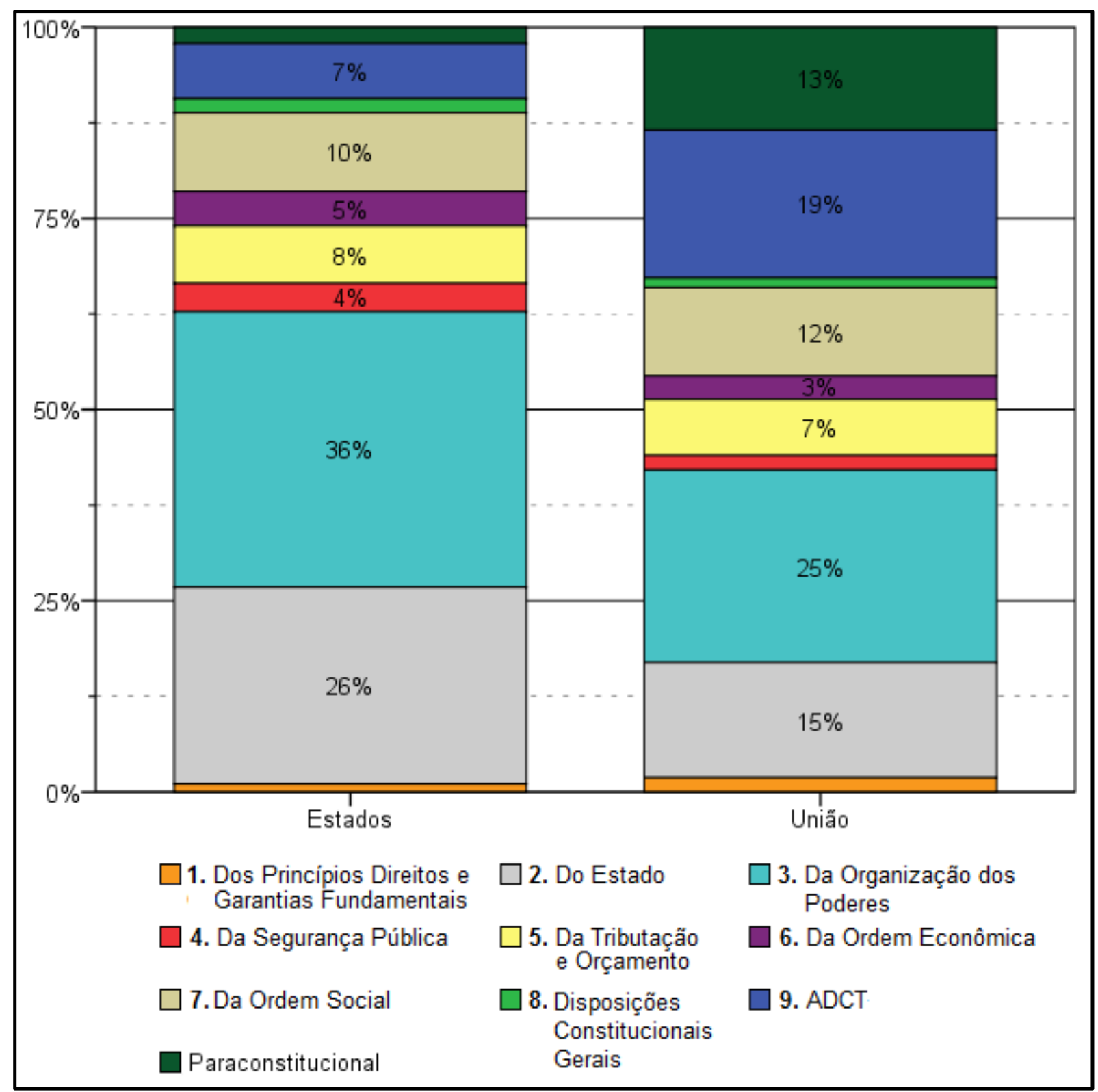

Gráfico 3.8 - Emendamento agregado nos Estados e União, proporcional aos Títulos

Enquanto o emendamento estadual se concentra principalmente sobre os Títulos 2 e 3, o emendamento Federal não é tão concentrado. Embora o Título 3 seja também aquele com maior emendamento na Constituição Federal, os demais Títulos são proporcionalmente mais significativos. O maior contraste entre o emendamento Federal e o Estadual se dá nos Títulos 9 e 10 (ADCT e Paraconstitucional). Nos estados o ADCT representa aproximadamente 5\% de todo o emendamento estadual, com média de 20 dispositivos por estado, enquanto os dispositivos 
Paraconstitucionais representam aproximadamente 2\%, com média de 9 dispositivos por unidade federativa. Já nas emendas federais o ADCT comporta 19\% dos dispositivos, enquanto os Paraconstitucionais somam 13\%. Assim não só a Constituição Federal é mais emendada que a média das Constituições Estaduais, mas também é emendada de forma distinta. Não parece haver relação entre o emendamento por Título na Constituição Federal e na média das Constituições Estaduais. Em outras palavras, ceteris paribus, os estados parecem ter incentivos distintos da União para reformarem suas constituições.

Ao compararmos o emendamento por Título nos estados encontramos significativa heterogeneidade, os estados emendam seus Títulos de forma consideravelmente variável e o emendamento estadual médio também difere do padrão de emendamento encontrado na Constituição Federal. No entanto, esta variabilidade se encontra no emendamento em termos absolutos. Ao observamos 0 emendamento em termos relativos o cenário nos parece diferente. O Gráfico 3.9 contém o emendamento proporcional em cada estado. Isto é, sabendo o total de dispositivos que cada estado promulgou, quantos por cento incidiram sobre quais Títulos? Com isso temos o intuito de comparar uma estrutura geral da composição do emendamento e observar não só quanto cada Título cada estado emendou, mas também de que forma a Constituição de cada estado foi emendada. 


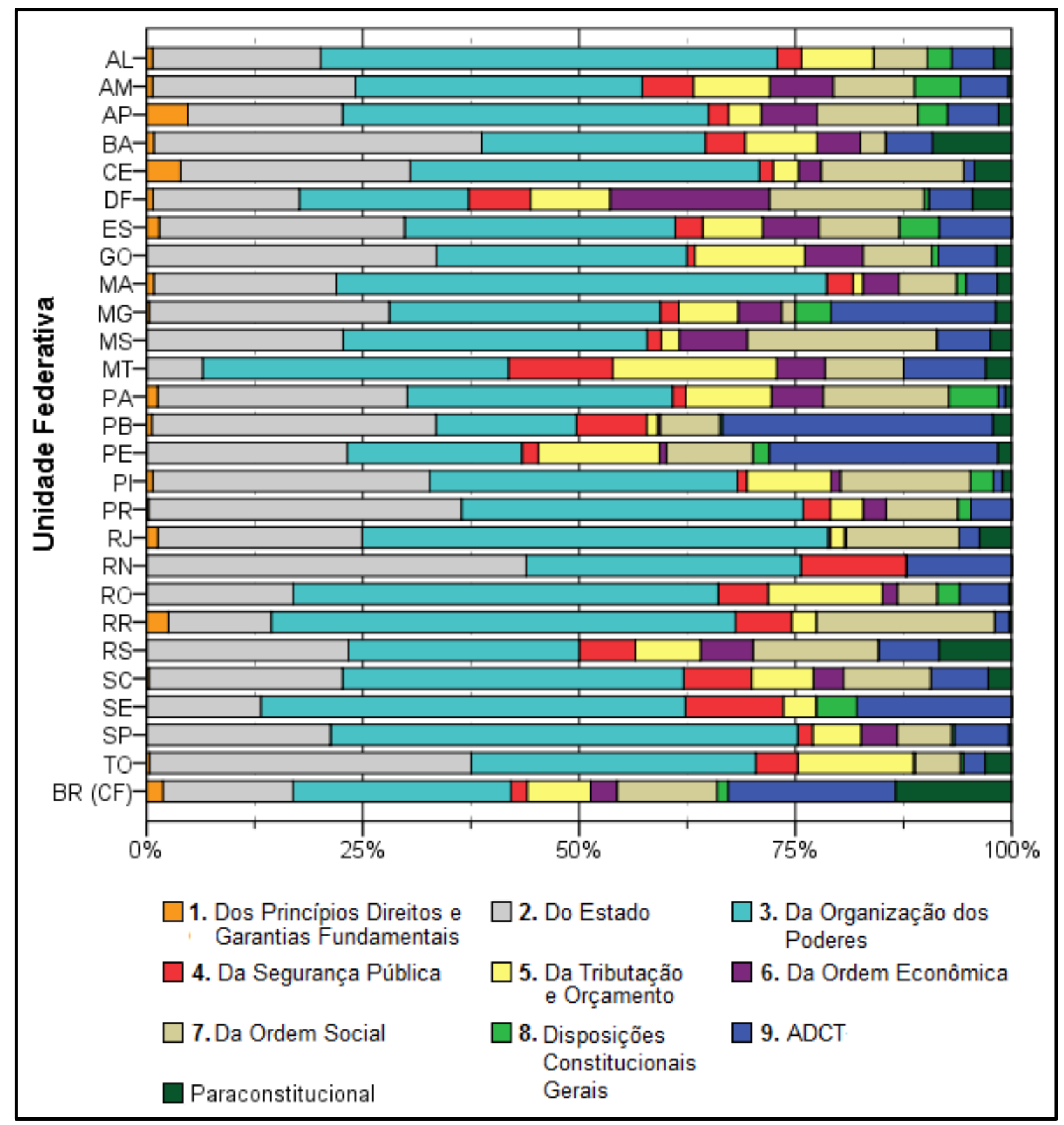

Gráfico 3.9 - Emendamento agregado nos Estados e União, proporcional aos Títulos

O Gráfico 3.9 aponta para o que nos parece certa homogeneidade na composição do emendamento, no entanto não sobre todos os Títulos. Ao avaliar o coeficiente de variação das proporções estaduais identificamos aqueles Títulos cuja composição apresenta maior variação. O coeficiente de variação dos Títulos 2 e 3 é de $37 \%$ e $28 \%$, respectivamente, enquanto nos demais Títulos varia de $60 \%$ a $145 \%$. Com isso identificamos a existência de uma homogeneidade parcial no emendamento dos estados. Ou seja, a proporção do emendamento estadual que incide sobre os Títulos 2 e 3 é relativamente constante entre todos os estados, mas a proporção do 
emendamento que incide sobre os demais Títulos possui variação elevada. Considerando que os Títulos 2 e 3 são também os com maior incidência de emendamento absoluto, então os estados apresentam emendamento proporcional equivalente na maior parte de seu emendamento, enquanto que o restante incide de formas diferentes entre os Títulos entre os estados.

De forma análoga podemos efetuar a mesma análise relativizando por ano, o que apontaria para a existência de alguma semelhança nos temas dos dispositivos de emenda promulgados ao ano e possivelmente a existência de tendências na composição dos temas emendados. O Gráfico 3.10 apresenta os valores proporcionais dos dispositivos de emenda constitucional em cada ano com divisão de Títulos. Assim observamos que não parece haver diferença entre a composição do emendamento anual. Isto é, todos os anos apresentam emendamento relativo semelhante. Mesmo que certa variação seja observável, esta não é intensa o suficiente ${ }^{56}$ para sugerir que de alguma forma existe tendência no emendamento proporcional. E quando consideramos os coeficientes de variação encontramos resultados semelhantes aos anteriores, isto é, os Títulos 2 e 3 apresentam a menor variação em sua proporção anual ${ }^{57}$, enquanto os demais apresentam variação elevada. Ou seja, também quando consideramos o emendamento ao ano temos que os Títulos 2 e 3 parecem ocupar uma parcela relativamente constante do emendamento, enquanto os demais Títulos variam anualmente.

\footnotetext{
${ }^{56} \mathrm{O}$ ano de 1989 pode ser considerado uma exceção, uma vez que apenas 7 dispositivos de emenda foram promulgados neste ano e é o ano em que as próprias Constituições Estaduais foram promulgadas.

${ }^{57}$ Coeficientes de Variação de $49 \%$ e $39 \%$ para os Títulos 2 e 3, o dos demais Títulos varia de $80 \%$ a $255 \%$.
} 


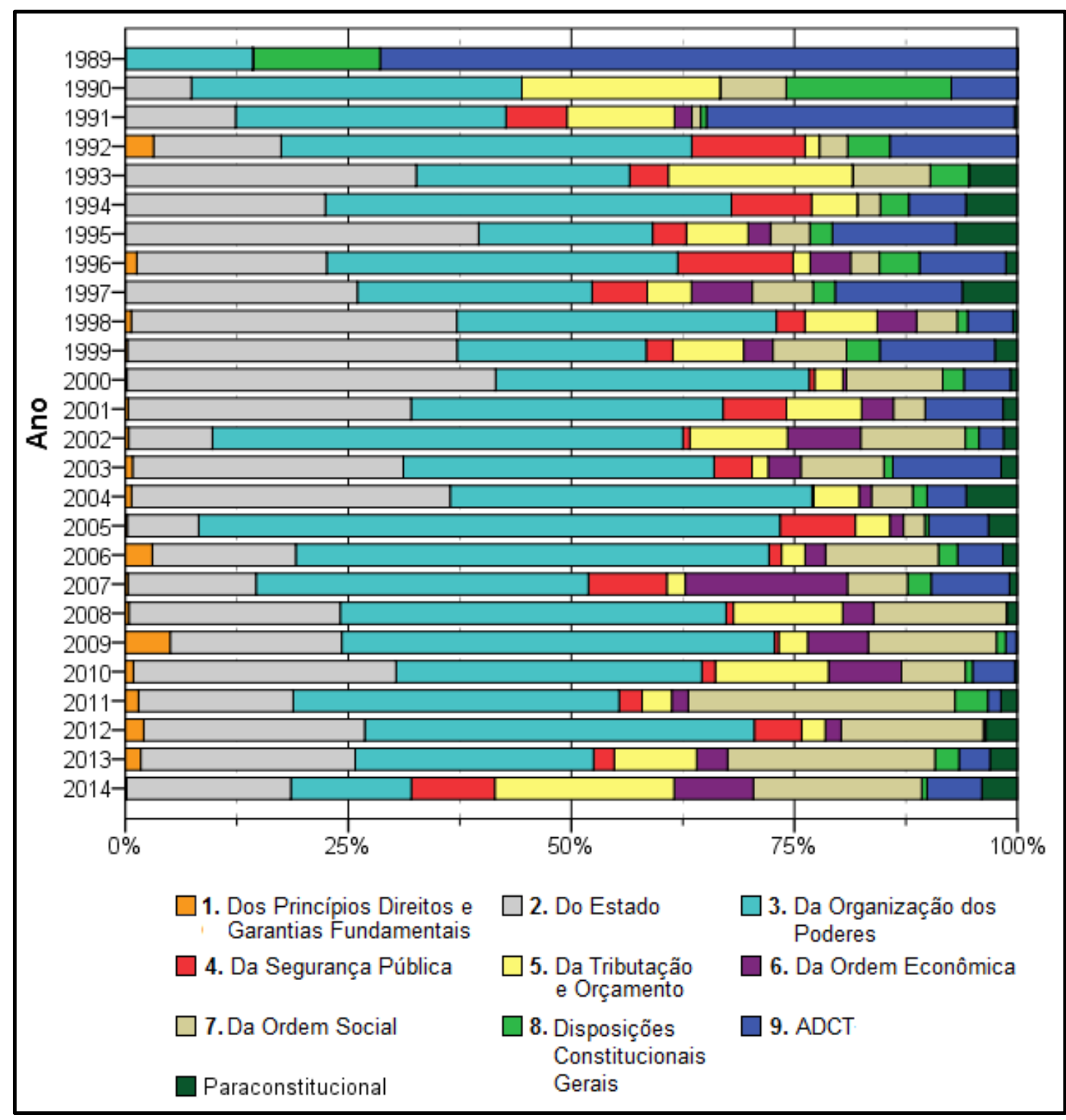

Gráfico 3.10 - Emendamento Anual, proporcional aos Títulos

A classificação dos dispositivos de emenda segundo os Títulos a que pertencem permite que uma discriminação do emendamento por tema seja realizada. Com a classificação por temas observamos que os Títulos são emendados em intensidades distintas. Os mais emendados são o Título 2 e o Título 3, que, juntos, representam aproximadamente $62 \%$ de todo o emendamento constitucional nos estados. No entanto, mesmo que tais Títulos sejam consideravelmente mais emendados que os demais, também observamos que parece existir certo padrão no emendamento. 
Apesar de os estados alterarem temas, representados pelos Títulos padronizados, em intensidades diferentes, nos parece que o fazem de maneira equivalente para os Títulos 2 e 3 . Isto é, uma proporção semelhante de seu emendamento é destinada aos temas dos Títulos 2 e 3, enquanto os demais temas são tratados em proporções distintas de acordo com o estado, resultado que se repete ao considerar o ano. E quando comparamos com o emendamento à Constituição Federal encontramos uma diferença considerável na proporção. Os temas mais frequentes nas emendas à Constituição Federal não condizem com aqueles mais frequentes nas emendas às Constituições Estaduais.

\subsubsection{Natureza do Emendamento}

A partir da divisão das emendas promulgadas em dispositivos, é possível também classificar a natureza do emendamento. Qual seja, como o emendamento é um processo dinâmico, que ocorre ao longo do tempo e geralmente com relação a um texto constitucional original, é possível identificar não só qual o efeito do emendamento sobre o texto constitucional, mas também se emendas distintas incidiram sobre o mesmo dispositivo.

A fim de identificar o que chamamos de natureza do emendamento, nos utilizamos de uma simplificação da tipologia presente em Arantes e Couto (2002; 2006; 2009). Com base no modelo desenvolvido pelos autores classificamos os dispositivos de emenda constitucional como Aglutinadores, Modificadores, Dispositivos de Múltiplas Rodadas, Revogadores e Renumeradores. Em virtude da frequência e importância relativamente reduzida dos dispositivos Renumeradores, foram omitidos dos gráficos.

Consideramos como dispositivo aglutinador aquele que acrescenta novos dispositivos à Constituição Original. Assim, se uma emenda constitucional insere um dispositivo que não fora encontrado na Constituição Original, o dispositivo em questão é considerado aglutinador. Os modificadores são aqueles que alteram o texto de dispositivos constitucionais que podem ser encontrados nas Constituições Originais. Portanto, se o dispositivo constitucional como um todo pode ser encontrado na 
Constituição promulgada, mas um dispositivo de emenda Constitucional acrescenta ou remove termos ou palavras ao dispositivo já existente, o dispositivo de emenda foi considerado modificador. Os dispositivos de múltipla rodada são aqueles em que foi possível identificar emendamentos subsequentes sobre o mesmo dispositivo constitucional. Isto é, um dispositivo que a princípio foi adicionado ou modificado, foi posteriormente alterado por outra Emenda Constitucional. Por fim os Revogadores são aqueles dispositivos que revogam conteúdo da Constituição Original. Note que um dispositivo deste tipo pode resultar na revogação de um ou mais dispositivos da Constituição Original ${ }^{58}$, dependendo de sua redação.

Fazemos distinção entre os dispositivos revogadores e os dispositivos revogados. Os dispositivos revogadores são aqueles dispositivos encontrados em Emendas Constitucionais que indicam expressamente a revogação ou supressão de elementos ${ }^{59}$ da Constituição. Já os dispositivos revogados são aqueles que por efeito de uma revogação expressa em uma Emenda Constitucional são removidos do texto da Constituição. O primeiro tipo é encontrado em emendas constitucionais e, portanto, são considerados dispositivos de emenda, enquanto o segundo tipo se encontra no texto principal, constituindo o alvo das provisões revogadoras.

O Gráfico 3.11 apresenta as classificações encontradas. Note que há também uma coluna denominada de "Outros", que contém os dispositivos renumeradores e alguns casos especiais que serão discutidos separadamente, já que sua quantidade não causa impacto na análise agregada, mas sua natureza é peculiar. Esta coluna será posteriormente desconsiderada na análise.

\footnotetext{
${ }^{58}$ Por exemplo, o Artigo segundo da EC 30 de Alagoas indica que o Art. 12 do Ato das Disposições Constitucionais Transitórias fica revogado. Muito embora isso seja expresso em apenas um dispositivo de emenda, o artigo revogado contém cinco dispositivos.

59 Identificamos como elementos os artigos, parágrafos, incisos, alíneas e itens. A revogação ou supressão é sempre expressa sobre pelo menos um elemento de forma integral. A remoção de palavras ou termos dentro de um elemento não consiste revogação, mas sim modificação.
} 


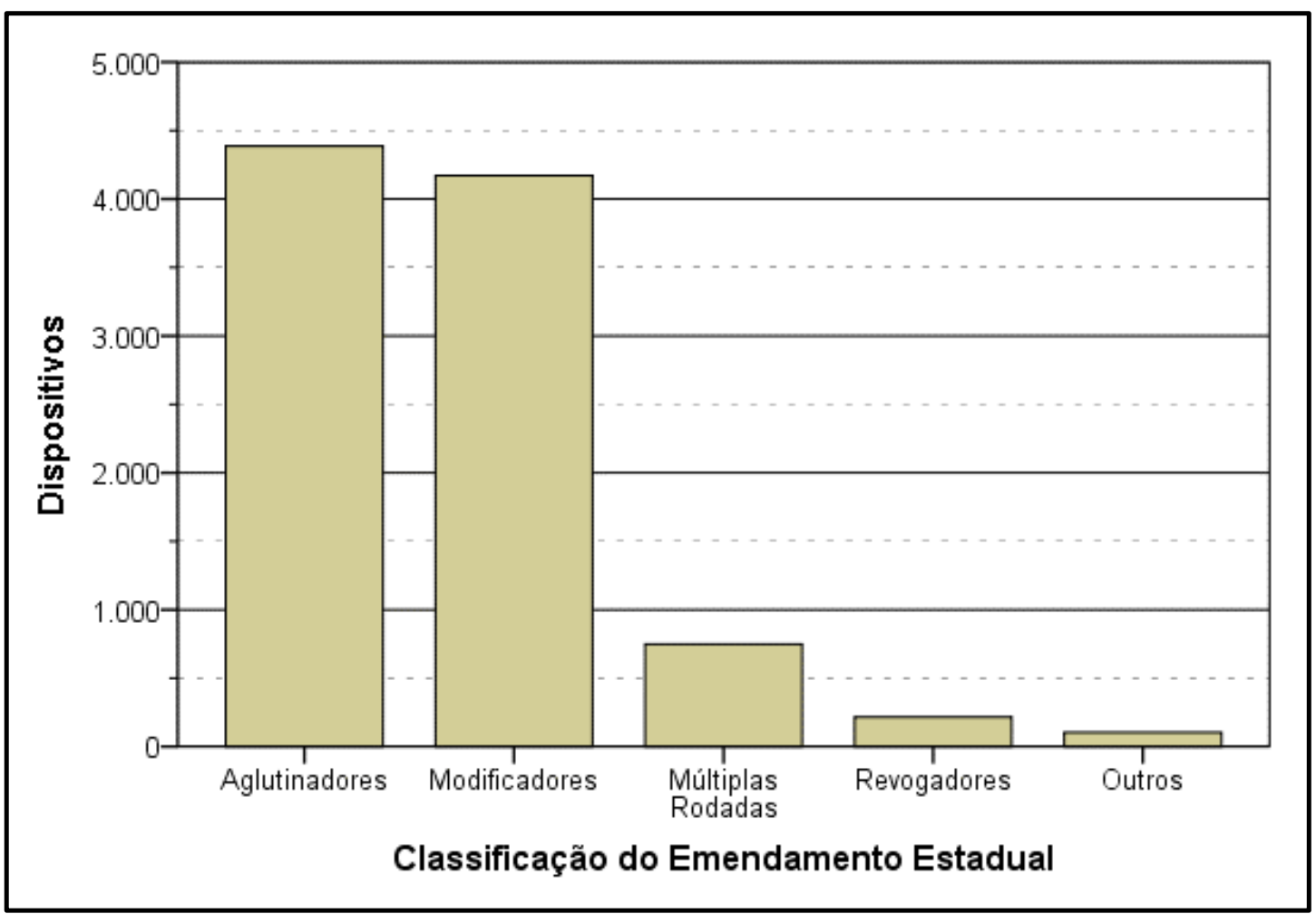

Gráfico 3.11 - Total de Dispositivos de Emenda por tipo de emendamento

Do total de dispositivos avaliados 4.387 (45\%) vieram adicionar novos dispositivos às Cartas Originais, $4.172(43 \%)$ modificaram dispositivos já existentes, $748(8 \%)$ são dispositivos que já se encontram em duas ou mais rodadas, 217 (2\%) revogaram dispositivos presentes nas Constituições originais ou que foram adicionados por emendas anteriores ${ }^{60}$ e $104(2 \%)$ classificados sob a categoria outros, sendo 6 desses casos especiais. Em média os estados acrescentaram 169 dispositivos, modificaram 161 em primeira rodada, 29 em múltiplas rodadas e 8 foram de caráter revogador.

Se considerarmos apenas a primeira rodada de emendamento vemos que a maioria dos dispositivos de emenda constitucional agregou novos dispositivos às Cartas Constitucionais. No entanto, ao considerarmos também as rodadas posteriores, a maioria dos dispositivos (4.920) tem a função de modificar algum dispositivo já existente. Isso porque segundo nossa classificação os dispositivos de múltipla rodada serão sempre modificadores. Encontramos dois casos, um em

\footnotetext{
${ }^{60}$ Optamos por classificar os revogadores de segunda rodada como revogadores a fim de simplificar a classificação, já que um mesmo dispositivo revogador pode incidir sobre diversos outros dispositivos então é possível que seja ao mesmo tempo revogador de um dispositivo que fora adicionado e de outro que fora modificado
} 
Roraima e outro no Espírito Santo ${ }^{61}$, de dispositivos de quinta rodada. Isto é, um dispositivo que veio modificar um dispositivo que já havia sido modificado outras quatro vezes. Dentre os de múltipla rodada, 217 são dispositivos que modificam dispositivos que foram aglutinados por emendas anteriores, os demais são cadeias de modificadores. Sendo assim, ao considerar a totalidade dos dispositivos modificadores, estes representam a maior parcela dos dispositivos de emenda constitucional. Todavia a diferença entre os aglutinadores e o total de modificadores é de apenas 533 dispositivos.

Se o total de dispositivos aglutinadores nos indica que foram adicionados 4.387 dispositivos às Constituições, os revogadores indicam apenas quantos dispositivos de emenda constitucional foram de caráter revogador. A fim de identificar seu impacto nos textos constitucionais é necessário identificar os dispositivos revogados. Então o impacto líquido nos textos estaduais é a diferença entre os dispositivos aglutinadores e os dispositivos revogados.

Identificamos dois tipos de dispositivos revogados, aqueles que foram removidos da Constituição por meio de revogação expressa nos dispositivos revogadores e aqueles que foram removidos da Constituição sem revogação expressa. Este segundo tipo de dispositivo revogado, embora raro, pode ser identificado ao comparar a mudança no texto da Constituição Original com o emendamento. Se por efeito de modificação na Constituição um dispositivo for removido sem que haja qualquer menção expressa ${ }^{62}$, é então um dispositivo revogado do segundo tipo. Assim um dispositivo revogador revoga pelo menos um dispositivo,

\footnotetext{
${ }^{61}$ No caso do Espírito Santo são as emendas de número 14, 15, 27, 40 e 99. Em todas as emendas há alteração do parágrafo quinto do Art. 58 da Constituição do Estado. Este versa sobre a eleição e mandato da mesa diretora da Assembleia. Em Roraima as emendas 7, 14, 20, 29 e 30 alteram o inciso XVIII do Art. 33, que versa sobre a aprovação, por parte da assembleia legislativa, dos titulares da Defensoria Pública, Procuradoria-Geral, etc.

$62 \mathrm{Na}$ EC 2 do Amazonas há indicação de que o Art. 116 da Constituição é alterado e sua nova redação é explicitada na emenda. No entanto não é possível identificar a natureza da alteração apenas pelo texto da emenda, para tanto comparamos o novo texto do Art 116 dado pela EC $2 \mathrm{com}$ o texto do Art. 116 encontrado na Constituição Original. Neste caso identificamos que o caput e incisos I a IV do Art. 116 são transcritos de forma idêntica na emenda, portanto nestes dispositivos não há qualquer alteração Constitucional, e por isso não são contabilizados no banco. Todavia, na Constituição Original o Art. 116 contava também com um inciso $\mathrm{V}$ e um parágrafo único, ambos não identificados no texto da emenda. Portanto o que ocorreu foi a revogação desses dois dispositivos do Art. 116 sem uma provisão revogadora expressa.
} 
mas não necessariamente um dispositivo é revogado apenas por efeito de um dispositivo revogador.

No total identificamos 217 dispositivos revogadores e 1.331 dispositivos revogados. Então em média cada dispositivo revogador revoga 6 dispositivos constitucionais $^{63}$. No entanto há grande diferença entre o impacto dos dispositivos revogadores, enquanto o dispositivo com menor impacto quantitativo é responsável pela revogação de apenas 1 dispositivo Constitucional, o maior ${ }^{64}$ identifica a revogação de 102 dispositivos constitucionais, sendo que o estado que mais revogou dispositivos constitucionais no intervalo foi o Tocantins (147 dispositivos revogados). Se no total foram acrescentados 4.387 dispositivos e revogados 1.331 , então o crescimento das Constituições Estaduais, agregadas, foi de 3.056 dispositivos, ou um crescimento médio de 117 dispositivos por estado (média de 4,5 dispositivos por ano em cada estado). No mesmo período ${ }^{65}$ a Constituição Federal acrescentou 656 dispositivos e revogou 80, portanto um crescimento de 576 dispositivos (média de 31 dispositivos por ano). Se a extensão média das Constituições Estaduais é de 1.264 dispositivos, o crescimento relativo médio foi de aproximadamente $10 \%$, já a Constituição Federal cresceu aproximadamente 33\% (ARANTES; COUTO, 2010). Mas em virtude da variabilidade encontrada nos estados, a generalização do crescimento constitucional estadual fica prejudicada. No mesmo período a Constituição de Minas Gerais teve saldo positivo de 335 dispositivos, o que representa crescimento de $21 \%$ em sua Constituição Original. Todavia, a Paraíba apresenta saldo negativo de 33 dispositivos, uma diminuição de $2 \%$ na extensão de sua Constituição.

\footnotetext{
63 Para simplificar os dados optamos por agregar os dois tipos de dispositivos revogados. Então formalmente os 1.366 dispositivos não foram consequência dos 217 dispositivos revogadores, com isso a média de dispositivos revogados por dispositivo revogador é ligeiramente sobrestimada.

${ }_{64} \mathrm{Em}$ apenas um dispositivo de emenda constitucional identificamos a revogação expressa de 102 dispositivos da Constituição de Pernambuco. O dispositivo em questão é o Art.6o da EC 16, de 1999. Este é responsável pela revogação quase integral do ADCT. Dos 96 dispositivos (64 artigos) encontrados no ADCT, esta emenda revoga 95 dispositivos (63 artigos). Apenas o Art. 64, acrescentado pela EC 12, não é revogado, todos os demais, promulgados com a Constituição Original, são revogados. O Texto do dispositivo revogador em questão é "Art. $6^{\circ}$ Revogam-se as disposições em

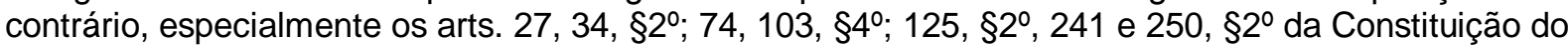
Estado e os artigos 1ㅇ a 63 do Ato de Disposições Constitucionais Transitórias" (PERNAMBUCO, 1989) ${ }^{65}$ Embora o período seja o mesmo a classificação do emendamento à Constituição Federal entre 2011 e 2014 não foi feita, no entanto apenas 86 dos 1.117 dispositivos de emenda foram promulgados neste período.
} 
Do Gráfico 3.12 vemos que ao considerar o emendamento em termos proporcionais, as Constituições Estaduais, no total, apresentam padrão de emendamento distinto daquele encontrado na Constituição Federal66. Embora em ambos os casos os dispositivos revogadores e os de múltipla rodada ocupem papel marginal, enquanto nos estados os dispositivos modificadores são promulgados quase na mesma quantidade que os dispositivos aglutinadores, na Constituição Federal o emendamento é quase três vezes mais aglutinador do que modificador.

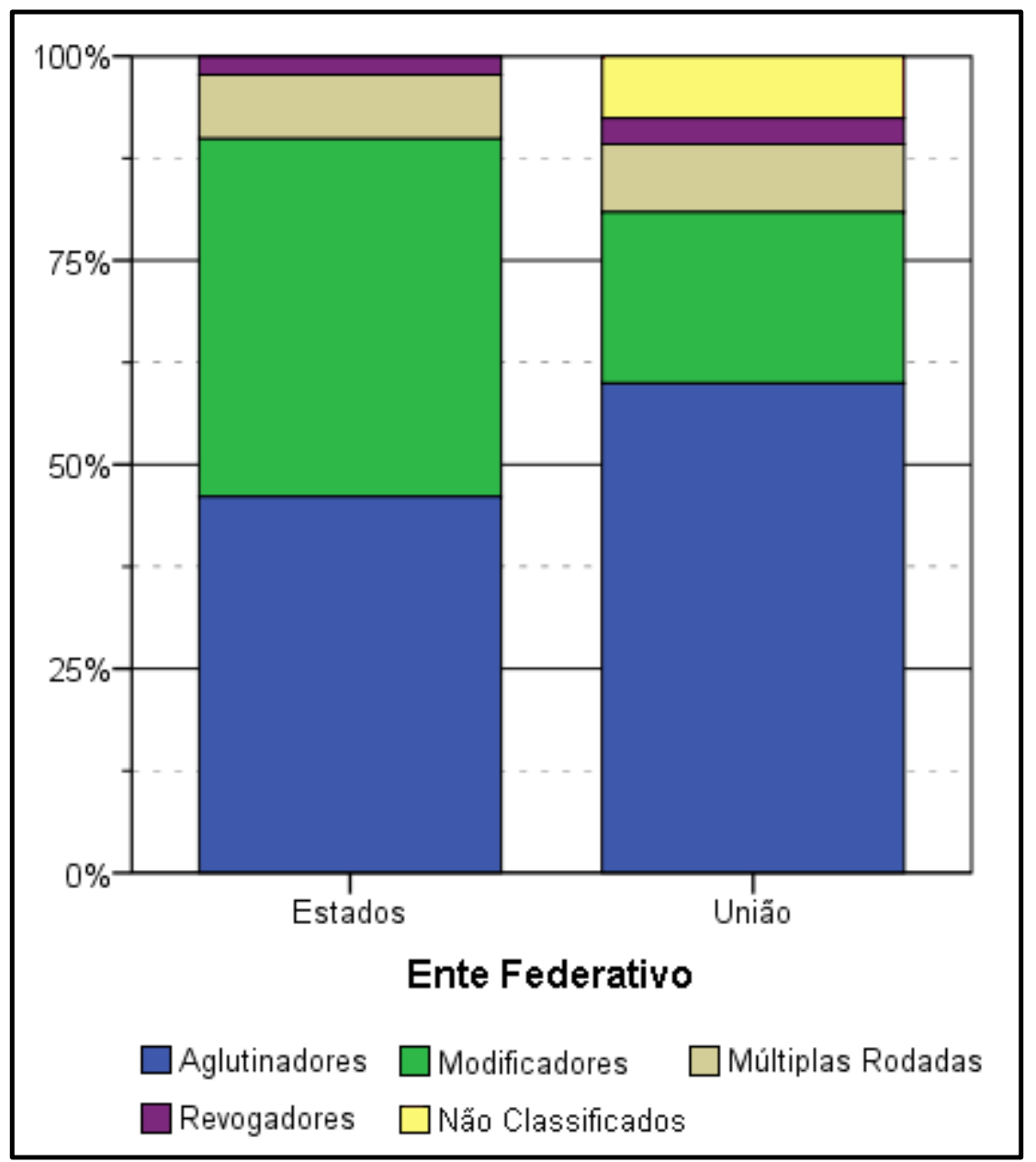

Gráfico 3.12 - Proporção do Tipo de Emendamento por Ente Federativo

Ao relativizar a natureza do emendamento por unidade federativa, isto é, identificar do total do emendamento observado em cada unidade federativa qual a proporção de qual natureza em cada uma, encontramos que em média, os dispositivos

\footnotetext{
66 Os dispositivos de Emenda à Constituição Federal foram classificados até a EC 64, de 2010. Então em vez de remover da análise aqueles promulgados nos anos posteriores, optamos por discriminar os não classificados (125 dos 1.117 dispositivos) a fim de manter o recorte temporal equivalente com os estados.
} 
aglutinadores são responsáveis por $46 \%$ do emendamento nos estados, os modificadores representam proporção de $44 \%$, os de múltipla rodada $8 \%$ e os revogadores $2 \%$. Embora haja pouca variação na proporção de aglutinadores e modificadores (ambos apresentam coeficiente de variação de 22\%), o Gráfico 3.13, bem como as medidas de dispersão, permitem identificar variação relativamente superior nas proporções dos dispositivos de múltiplas rodadas e revogadores (coeficiente de variação de $58 \%$ e $50 \%$ respectivamente).

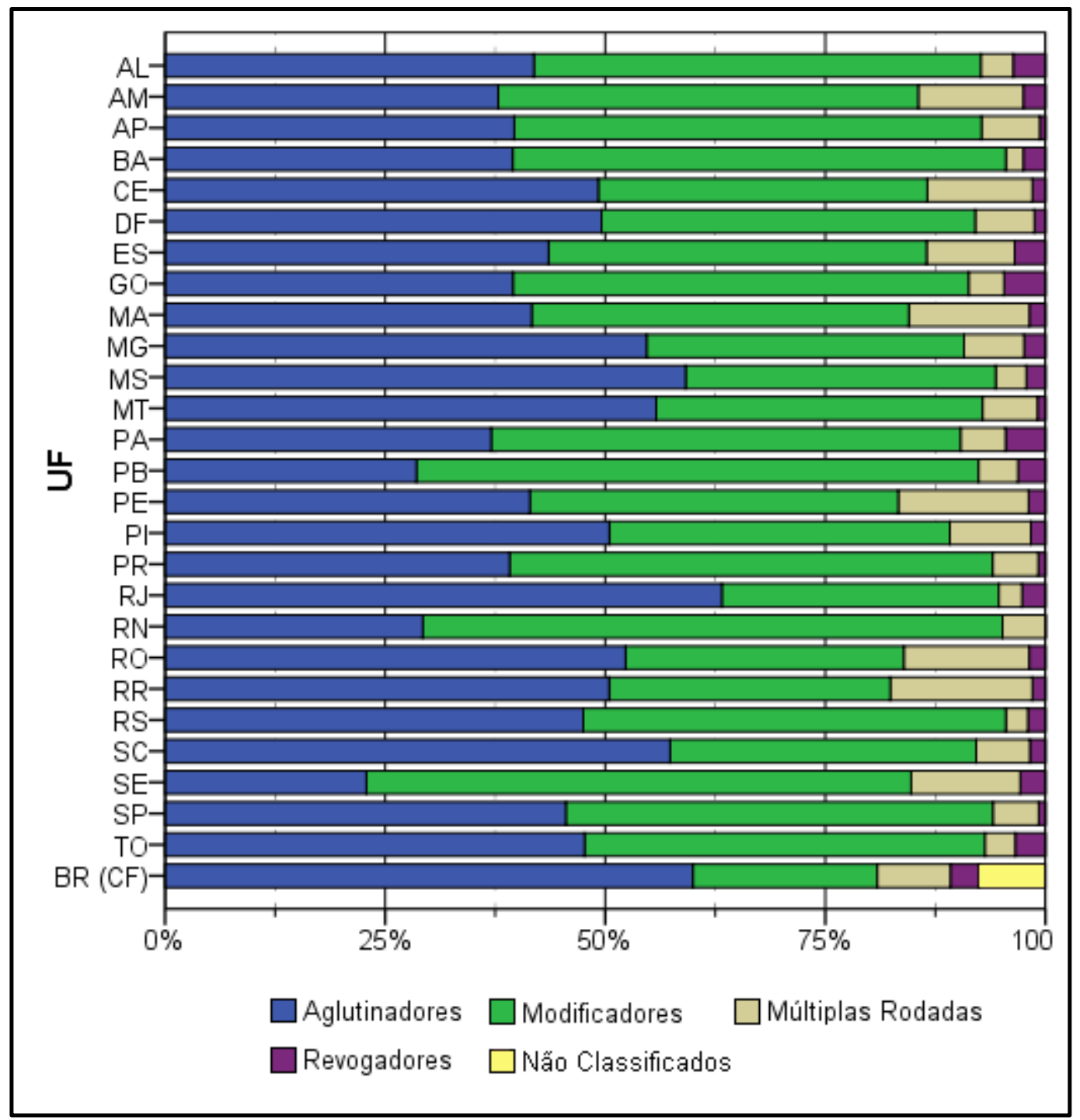

Gráfico 3.13 - Proporção de Tipo de Emendamento por UF mais União

Mesmo que exista variabilidade nos tipos de emendamento perpetrado por cada estado, esta variabilidade é mais bem observada em termos absolutos. Ao relativizarmos pela composição relativa do emendamento de cada estado, vemos que a variação no quanto cada estado aglutina ou modifica apresenta variabilidade 
reduzida. Ou seja, de forma geral os estados aglutinam e modificam dispositivos às suas cartas de forma relativamente equivalente. Do Gráfico 3.13 também vemos que embora alguns estados apresentem proporção de aglutinadores semelhante à encontrada nas emendas à Constituição Federal, a proporção de modificadores é distinta, levando em consideração os $8 \%$ de dispositivos não classificados no emendamento Federal.

A fim de avaliar a mudança constitucional ao longo do tempo relacionamos a natureza dos dispositivos promulgados com os anos de forma análoga ao realizado para as unidades federativas. Assim foi possível construir uma linha do tempo que indica em cada ano quantos dispositivos são classificados segundo cada categoria da classificação. O Gráfico 3.14 expõe os valores absolutos. Isto é, em cada ano quantos dispositivos de cada tipo foram promulgados. Não nos parece existir padrão observável. Como já foi visto, há significativa variação na quantidade de dispositivos promulgados ao ano, no entanto não há indícios de que haja alguma relação com o tipo de emendamento, já que pelo gráfico a quantidade de emendas de cada tipo parece equivalente.

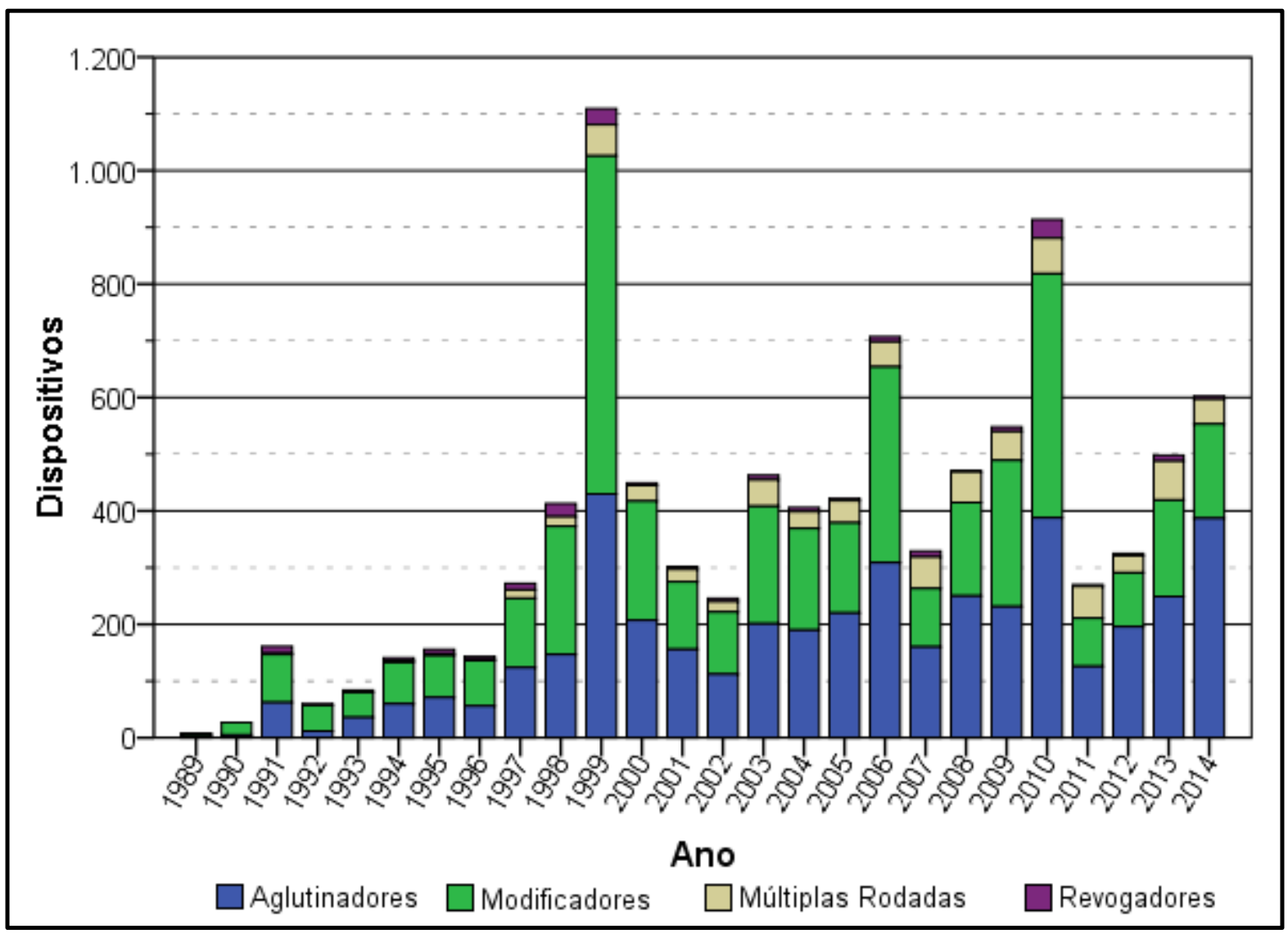

Gráfico 3.14 - Tipo de Emendamento ao Ano 
Mas ao calcular as frequências relativas em cada ano, os dispositivos aglutinadores aparentemente vem se tornando mais frequentes com o tempo. O Gráfico 3.15 apresenta a proporção, por ano, da natureza do emendamento. Desde 1989 até 2014 a frequência relativa de dispositivos de emenda constitucional que adicionam dispositivos inéditos aos textos constitucionais parece se elevar, mesmo que em termos absolutos isso não seja aparente. Ou seja, com o passar dos anos a inclusão de novos dispositivos às Cartas Estaduais vem se tornando proporcionalmente mais frequente, mesmo que de maneira não uniforme, enquanto a utilização de mecanismos de modificação da carta aparenta dinâmica simetricamente oposta. Já os de múltipla rodada sugerem um crescimento, o que é de se esperar, uma vez que com o passar dos anos o emendamento modificador terá, geralmente, maior probabilidade de incidir sobre algum dispositivo anteriormente alterado ou adicionado.

De maneira similar a Constituição Federal também eleva a proporção de dispositivos aglutinadores entre 1992 e 2010, mas de forma não simétrica com a proporção de modificadores. Assim o emendamento estadual ao ano parece indicar uma tendência de opção pela adição de novos dispositivos às cartas em detrimento da modificação. Mesmo se considerarmos os dispositivos de múltiplas rodadas dentro dos modificadores, ainda assim observamos aparente redução na proporção de modificadores e elevação nos aglutinadores. 


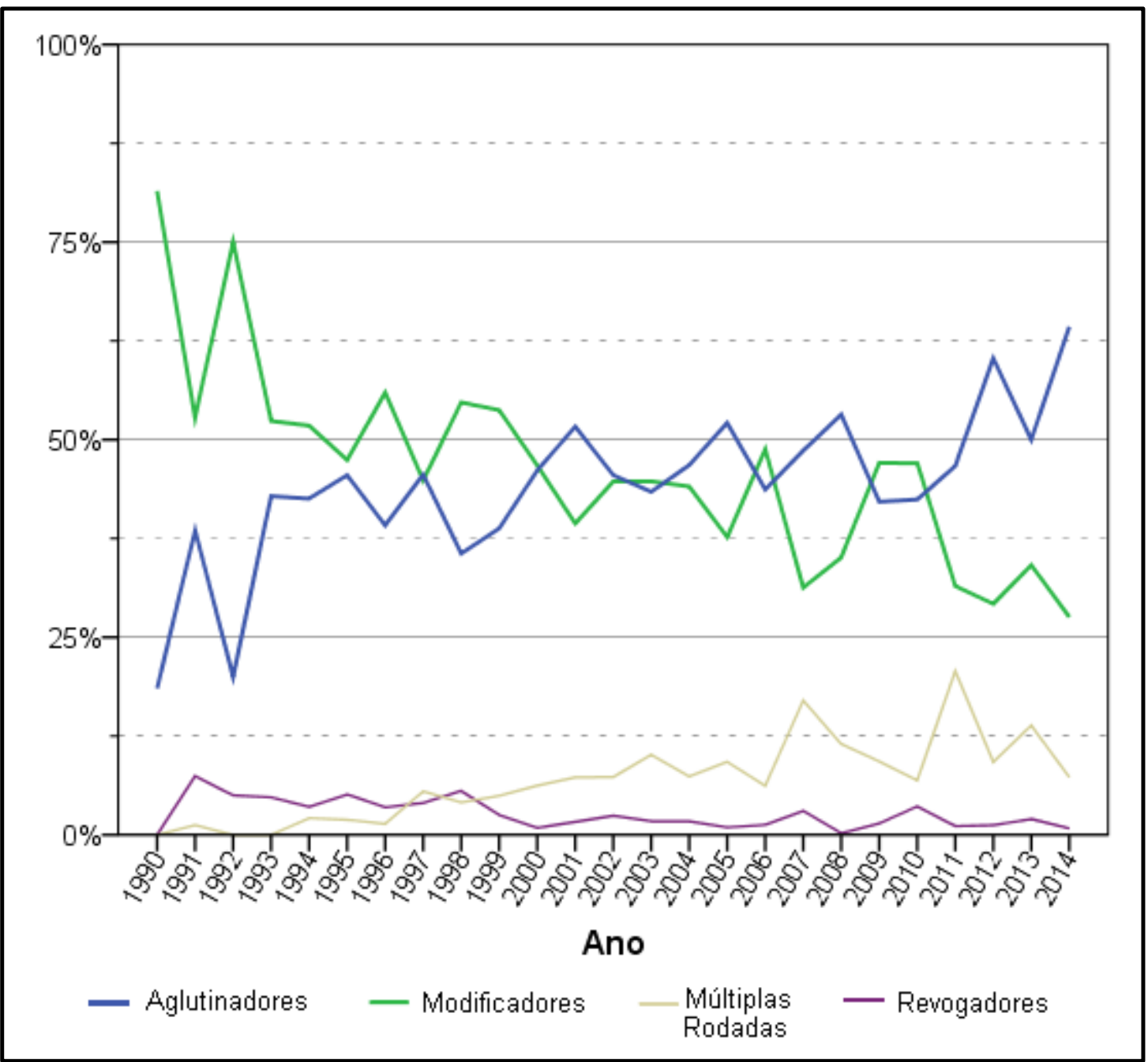

Gráfico 3.15 - Proporção de Tipo de Emendamento ao Ano

Tendo em vista classificação dos dispositivos em temas, ao utilizarmos a classificação da natureza do emendamento podemos identificar também como os Títulos Constitucionais foram emendados. O Gráfico 3.16 aponta para certa proporcionalidade entre os Títulos. Ao observar o tipo de emendamento por título nos estados há indícios de que o padrão de emendamento é semelhante na maioria deles, os aglutinadores e modificadores são responsáveis por quase a integralidade do emendamento e entre si apresentam variabilidade reduzida. Quando comparado com o emendamento à Constituição Federal o contraste é significativo, mesmo considerando os 125 dispositivos não classificados vemos que, proporcionalmente, o tipo de emendamento por Título na Constituição Federal e no total estadual não se assemelha. 


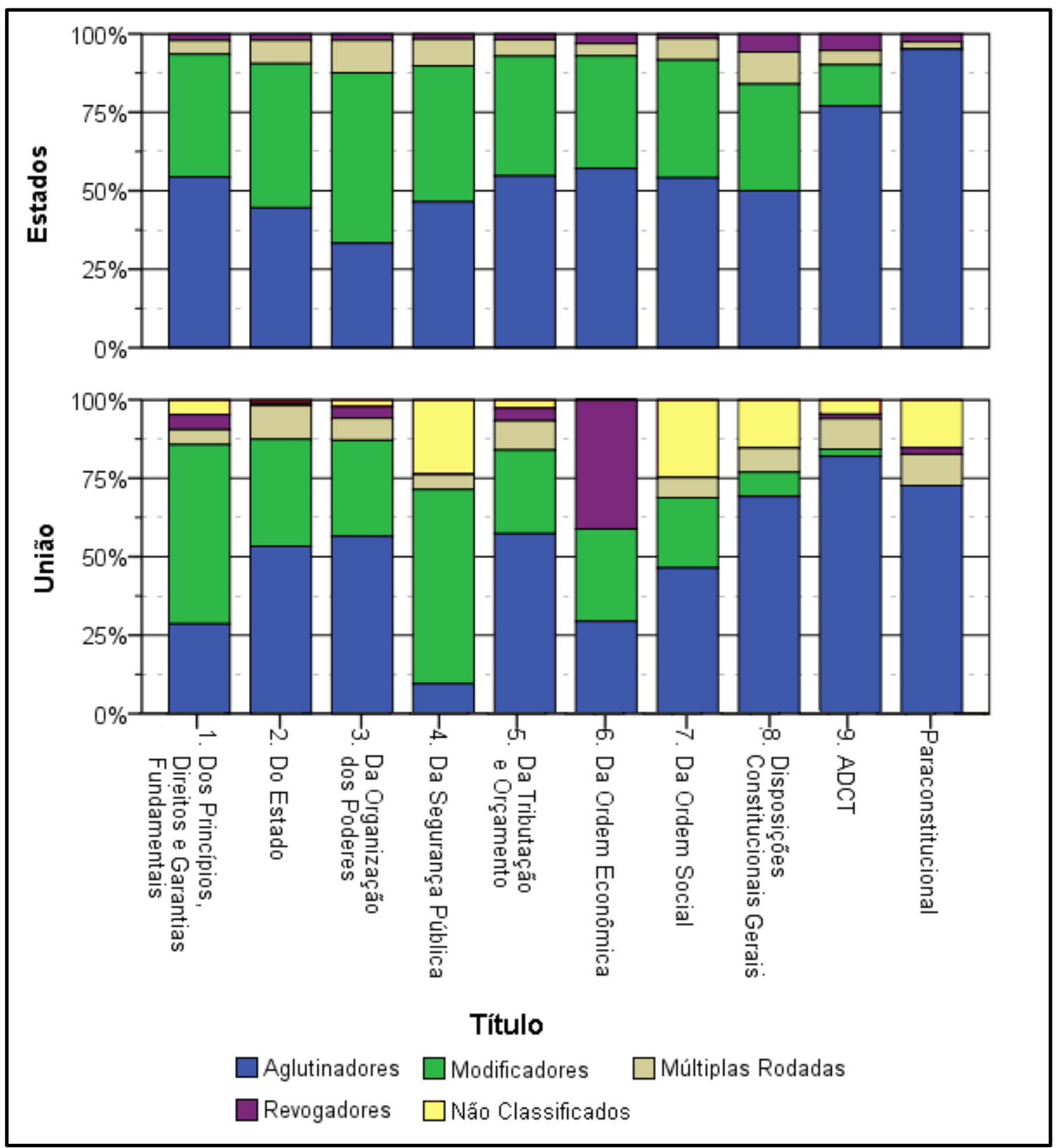

Gráfico 3.16 - Proporção de Tipo de emendamento por Título, total Estadual e Federal

No entanto o cenário encontrado no ADCT e nos dispositivos Paraconstitucionais é diferente. Em relação ao emendamento estadual vemos que nesses dois Títulos a proporção é majoritariamente de dispositivos aglutinadores e seu padrão de emendamento é semelhante ao encontrado na Constituição Federal. Tanto essa similaridade quanto a primazia de dispositivos aglutinadores são esperadas nos dispositivos paraconstitucionais, já que por sua característica devem necessariamente ser adicionados por meio de uma emenda constitucional à Constituição, logo, não é possível encontrar modificadores de primeira rodada nesta 
categoria, mas dos dados também vemos que não são alvo frequente de alteração ou revogação, usualmente são simplesmente adicionados.

Já no caso do ADCT, em virtude da natureza teoricamente transitória das normas nele contidas, esperávamos encontrar maior frequência de dispositivos revogadores e modificadores, e não a primazia dos aglutinadores. Essa frequência relativa mais elevada de dispositivos aglutinadores também é observada nas emendas à Constituição Federal, o que, segundo Arantes e Couto (2009), sugere certa continuação na transição constitucional.

O que consideramos caso especial consiste em múltiplas revogações encontradas no emendamento de Goiás. A EC 8 de Goiás modifica o parágrafo único do Art. $80^{67}$ bem como acrescenta 5 dispositivos a este artigo. Esta emenda então contém um dispositivo modificador e 5 dispositivos aglutinadores. Posteriormente a EC $19^{68}$ revoga integralmente o Art. 80, em seguida, a EC $21^{69}$ revoga a própria EC 19, finalmente, a EC $23^{70}$ revoga também a EC 21. Então, em primeiro lugar uma série de dispositivos foram acrescentados por uma emenda (EC 8), em seguida tais dispositivos foram diretamente revogados (EC 19) para que uma emenda posterior (EC 21) revogasse integralmente a EC 19. Com isso, a disposição constitucional que revogou o Art. 80 é também revogada. Finalmente, uma última alteração constitucional (EC 23) revoga a disposição constitucional que revogara as anteriores.

Este caso, a princípio um tanto quanto confuso, representa uma série de emendamentos sobre emendamentos, com emendas sendo diretamente revogadas

\footnotetext{
${ }^{67}$ O Art. 80 da Constituição de Goiás versa a respeito do Tribunal de Contas do Município, pela EC 8 são determinados os critérios de escolha dos Conselheiros do Tribunal, antes não especificado.

${ }^{68}$ Além de revogar integralmente o Art. 80, a EC 19 extingue o Tribunal de Contas do Município, por meio do acréscimo de dispositivos no ADCT (são acrescentados os Art. 29 a 34, cada um com um dispositivo) e paraconstitucionais, que o tornam parte integrante do Tribunal de Contas do Estado (mas seus cargos serão extintos à medida que vagarem) bem como determina que o controle externo das contas municipais será atribuição do Tribunal de Contas do Estado.

${ }^{69}$ A EC 21 recria o Tribunal de Contas do Município mas assegura a participação do Tribunal de Contas do Estado no controle das contas municipais. Além disso revoga a EC 19, e com isso os Artigos 29 a 34, por ela acrescentados - que versam sobre a incorporação do Tribunal de Contas do Município ao Tribunal de Contas do Estado - para finalmente promulgarem os Artigos 29 a 32 do ADCT com provisões exatamente opostas às encontradas nos artigos revogados, fazem menção direta e expressa a eles e separam o Tribunal de Contas do Município do Tribunal de Contas do Estado.

${ }^{70}$ Finalmente a EC 23 revoga a EC 21 e além da revogação redefine os critérios de escolha dos Conselheiros do Tribunal de Contas do Município e mais uma vez recria o Tribunal de Contas do Município, no entanto não o faz por meio da inclusão de dispositivos no ADCT, mas sim por modificação de dispositivos já existentes.
} 
por emendas posteriores. Essa situação em que uma norma revogadora é revogada pode gerar dúvidas a respeito de qual será a norma vigente ao final, e neste caso peculiar há uma sequência de três revogações seguidas. Pela tradição jurídica brasileira a repristinação ${ }^{71}$ não é aplicada, salvo em provisões expressas (Capez, 2003; Motta e Douglas, 2002; Temer, 1998). Como não há repristinação expressa em nenhuma das emendas e cada uma delas revoga integralmente a emenda anterior, temos que ao fim desta sequência de emendamentos ficam integralmente revogados o Art. 80, a EC 8, a EC 19 e a EC 21. Para Temer (1998) a repristinação em normas constitucionais não deve ser admitida principalmente em razão da dificuldade de interpretação gerada, situação ilustrada pelo caso que destacamos.

Um caso semelhante ocorre no emendamento do Ceará, no entanto este intercala revogações e aglutinações. Primeiramente a EC $11^{72}$ acrescenta o parágrafo segundo ao Art. 87 de sua Constituição. Em seguida, a EC $20^{73}$ revoga o parágrafo segundo que fora acrescentado pela EC 11, portanto é um dispositivo que revoga um que fora aglutinado. Já a EC $50^{74}$ novamente acrescenta o parágrafo segundo ao Art. 87, no entanto efetua ligeira modificação na redação. Finalmente, a EC $59^{75}$ novamente revoga o parágrafo segundo do Art. 87, mas, além de revogar tal parágrafo, esta emenda também acrescenta um dispositivo paraconstitucional que assegura a aplicação deste parágrafo revogado. Assim como no caso de Goiás, no

\footnotetext{
${ }^{71}$ Quando a repristinação é aplicada a revogação de uma norma revogadora faz com que a norma que fora revogada volte à vigência. Isto é, caso uma norma $A$ seja revogada por uma norma $B$, e esta norma $B$ revogada por uma norma $C$, pelo fenômeno da repristinação a norma $A$ volta a ter vigência.

72 "Art. $1^{\circ} \mathrm{O}$ Art. 87 da Constituição Estadual fica acrescido do parágrafo $2^{\circ}$, com a seguinte redação:"§2。 Cessada a investidura no cargo de Governador do Estado, quem o tiver exercido, em caráter permanente, fará jus, a título de representação, a um subsídio mensal e vitalício igual a remuneração do cargo de Desembargador Presidente do Tribunal de Justiça, percebida em espécie a qualquer título." (CEARÁ, 1989).

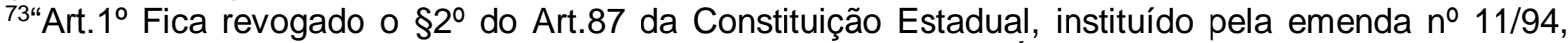
renumerando-se neste Artigo o Parágrafo remanescente." (CEARÁ, 1989)

74"Art. $1^{\circ}$. O Art.87 da Constituição do Estado fica acrescido de um parágrafo, passando o atual parágrafo único a ser o $\S 1^{\circ}$, tendo o $\S 2^{\circ}$ a seguinte redação: "Art.87. $\S 2^{\circ}$. O Governador e o ViceGovernador eleitos farão jus, desde que tenham exercido o cargo de Governador do Estado em caráter permanente e por período igual ou superior a seis meses, após cessada a investidura no cargo, a título de representação, a um subsídio mensal e vitalício igual à remuneração que for atribuída ao cargo de Governador do Estado do Ceará." (CEARÁ, 1989, grifo nosso)

${ }^{75 \prime A}$ Art. $1^{\circ}$ Fica revogado o $\$ 2^{\circ}$ do Art. 87 da Constituição do Estado do Ceará, acrescido pela Emenda Constitucional oㅜ 50, de 16 de dezembro de 2002;

Art.2ำ Fica assegurada a aplicação do disposto no $2^{2}{ }^{\circ}$ do Art.87 da Constituição do Estado do Ceará, acrescido pela Emenda Constitucional oㅡ 50, de 16 de dezembro de 2002, aos que tenham preenchido os requisitos nele previstos entre a data da publicação da Emenda Constitucional no 50 , de 16 de dezembro de 2002, e a da publicação desta Emenda Constitucional, desde que requeiram o benefício no prazo de até 180 (cento e oitenta) dias após cessada a investidura no cargo." (CEARÁ, 1989)
} 
Ceará é possível observar o emendamento sobre emendamento de forma única, em que um mesmo dispositivo é aglutinado e revogado de forma alternada para, finalmente, ter sua aplicação assegurada por meio de dispositivo paraconstitucional.

Embora essa situação peculiar tenha ocorrido apenas em dois estados, e em número suficientemente reduzido para que a classificação individual de seus dispositivos seja removida da análise sem que alterações nos resultados sejam observadas, demonstram certa inconstância no emendamento nos Estados. Com decisões opostas sendo tomadas sequencialmente em curto espaço de tempo.

A decomposição das emendas constitucionais em dispositivos permite também que a natureza do emendamento seja observada. Dos dados levantados há indícios de que os estados tem se utilizado proporcionalmente mais de dispositivos aglutinadores no emendamento de suas Constituições com o passar do tempo. Por um lado isso pode indicar que as Constituições Estaduais não só tem crescido, como apresentam tendência positiva nesse crescimento, tornando-se mais significativo com o passar dos anos. Por outro lado, pode significar apenas a mudança na proporção do tipo de emendamento utilizado, não necessariamente os aglutinadores são mais usados, mas possivelmente nos últimos anos as emendas tem alterado e revogado menos dispositivos.

Quando observamos a natureza do emendamento entre os estados, não nos parece haver indício de diferenças significativas. Assim nos parece que os estados se utilizam de forma semelhante dos dispositivos aglutinadores, modificadores e revogadores. As medidas de dispersão sugerem que a proporção é pouco variada, todavia podemos identificar casos extremos, um deles é o do Rio Grande do Norte, que apresenta proporção consideravelmente distinta dos demais estados. Este estado promulgou apenas 41 dispositivos de emenda, sendo os dois primeiros tipos mais frequentemente utilizados.

Finalmente, ao comparar de que forma os Títulos têm seus dispositivos acrescentados, modificados ou revogados, encontramos que em média não é possível observar diferenças significativas nas proporções. Isto é, em virtude da diferença do emendamento absoluto em cada Título encontramos diferenças marcantes na natureza dos dispositivos entre os Títulos, mas, quando consideramos as proporções, 
nos parece que a aglutinação, modificação ou revogação de dispositivos constitucionais não é mais associada com um ou outro Título. Com exceção do ADCT - que apresenta maior proporção de dispositivos revogados - e do Título que denominamos de Paraconstitucional, em razão de sua característica peculiar que não admite dispositivos de primeira rodada que não os aglutinadores.

\subsubsection{Autoria por ator institucional}

Com o levantamento das Emendas Constitucionais promulgadas também obtivemos a informação acerca da autoria do emendamento. Aqui consideramos por autor do emendamento aquele ator institucional que é identificado pelos dados disponíveis nas Assembleias Legislativas como o autor do Projeto de Emenda Constitucional que, uma vez aprovado, tornou-se emenda constitucional. Do total de 9.628 dispositivos de emenda constitucional levantados conseguimos acesso à informação da autoria de 5.119 dispositivos (53\% do total). Em virtude da organização de cada Assembleia Legislativa os dados que conseguimos não são distribuídos de forma equivalente entre os estados. Isto é, conseguimos informações de 14 dos 26 estados e em alguns estados a informação não está disponível para todas as emendas.

Um primeiro viés de seleção ocorre em razão do levantamento parcial dos dados, já que apenas a informação de parte dos estados foi considerada, no entanto este viés é consequência da falta de disponibilidade de informações. Há também outro viés de seleção no levantamento, este mais frequente na literatura de emendamento constitucional. Segundo Rasch (2008) um dos desafios metodológicos enfrentados pela literatura que trata do Emendamento Constitucional é o viés gerado pelo fato de que a seleção dos casos a serem analisados se dá com base nos resultados da própria variável. Isto é, no caso do emendamento constitucional, o levantamento feito é apenas sobre as emendas aprovadas. Portanto a autoria dos projetos de emenda constitucional também só será sobre aqueles projetos que foram aprovados, todos os projetos rejeitados são excluídos da análise.

A solução para tal viés seria o levantamento e análise de todos os projetos de emenda constitucional iniciados nas Assembleias Legislativas. Mas, a origem deste 
viés também não é totalmente excluída ao levantar os projetos iniciados - qual seja, os aprovados, rejeitados e em trâmite - já que com isso excluímos as tentativas de alteração constitucional que não foram iniciadas por conta de negociações e dinâmicas políticas além das proposições formais dos projetos nas Assembleias. Então, invariavelmente ocorrerá algum tipo de viés de seleção. Este último não possui solução metodológica, uma vez que sempre algum tipo de observação será descartada com base no resultado da variável dependente. Já o levantamento de todos os projetos, embora seja uma solução consideravelmente eficiente para o viés, torna-se inviável pela própria disponibilidade das informações. Poucas são as assembleias que disponibilizam os dados acerca dos projetos que foram aprovados e promulgados como emendas à constituição, menos ainda dos projetos que não foram aprovados.

Então, ao utilizar o ator institucional que consta na Proposta de Emenda Constitucional (PEC) disponibilizado pelas Assembleias incorreremos em viés de seleção, mas, a solução deste não é trivial. Ademais, pode-se criticar que o que consta como autor na PEC não é o real idealizador da norma, uma vez que por meio de negociações políticas e diferentes mecanismos e barreiras na proposição de Propostas de Emendas Constitucionais, o autor formal seja distinto do autor real. Exemplos neste sentido podem ocorrer quando o autor real de uma PEC seja o governador mas, em virtude de negociações, alianças partidárias ou quaisquer outros motivos, sua proposição na Assembleia se dá por meio dos deputados; ou o inverso disso, quando deputados são os autores verdadeiros mas a proposição é encaminhada pelo chefe do executivo (nesse caso, é bom considerar que a barreira para que um deputado inicie uma PEC é comparativamente maior do que a enfrentada por um governador). Muito embora esses tipos de situações sejam possíveis e tenham impacto sobre os resultados, essa dinâmica não formal não é observável, portanto não há solução simples para este problema.

A título de simplificação consideramos apenas os atores institucionais responsáveis pela autoria da $\mathrm{PEC}$. Isto é, caso o governador conste como autor da proposta, consideraremos o Poder Executivo, caso conste o nome de um deputado ou mais deputados, o autor será o Poder Legislativo. Novamente, esta abordagem foi 
escolhida não só em razão da maior simplicidade, mas principalmente da disponibilidade reduzida de informações detalhadas ${ }^{76}$. Também não é possível levantar as informações específicas de cada dispositivo, isto é, qual foi o autor responsável pela idealização de cada dispositivo aprovado. Portanto consideramos que todos os dispositivos de uma mesma emenda possuem a mesma autoria, qual seja, a autoria do autor da PEC.

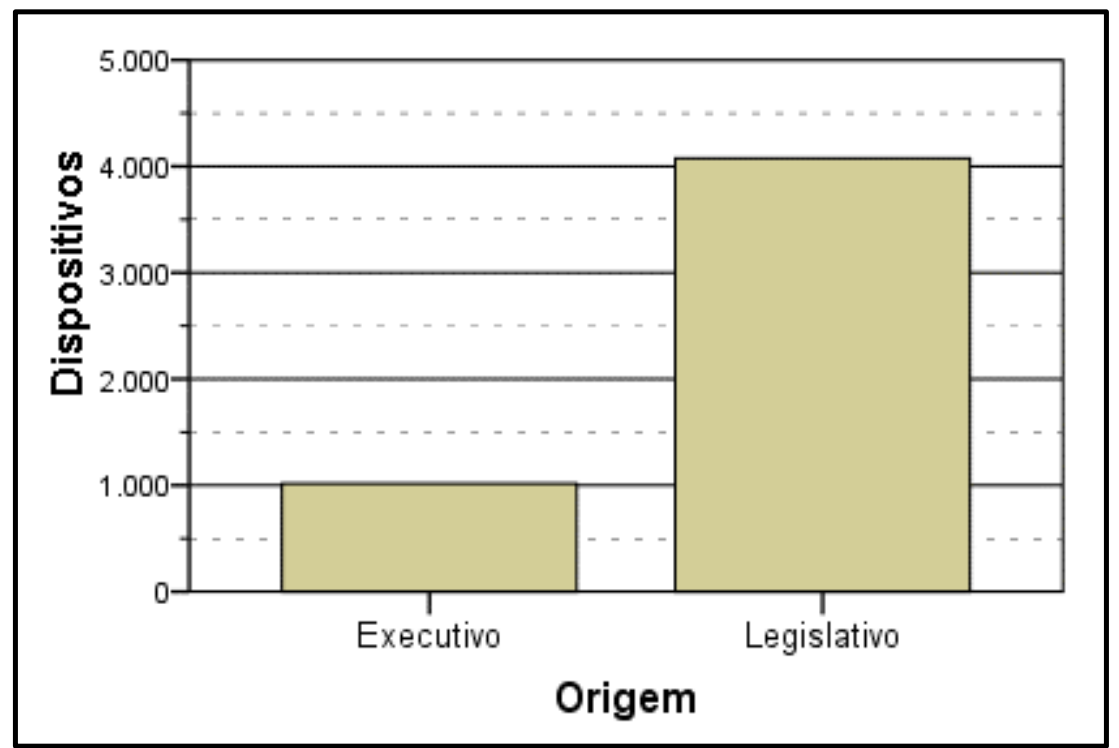

Gráfico 3.17 - Total de Dispositivos de Emenda por Ator Proponente

Quando considerados em conjunto, a maioria dos dispositivos de emenda constitucional promulgados pelos estados brasileiros teve como autor o Poder Legislativo. O Gráfico 3.17 apresenta os resultados. Dos 5.095 dispositivos considerados $^{77} 1.018$ foram de autoria do Poder Executivo enquanto 4.076 foram do Poder Legislativo. Em termos de emendamento Constitucional a dominância do Poder Legislativo sobre o Executivo é de $80 \%$, isto é, do total de dispositivos de emenda promulgados no período, $80 \%$ foram de autoria do Legislativo. Esse dado indica a relevância do Poder Legislativo na dinâmica legislativa estadual, especificamente sobre o Emendamento Constitucional. Embora a natureza legislativa seja diferente, Tomio e Ricci (2012a), e Tomio e Ricci (2012b), encontram dominância do Poder

\footnotetext{
76 Tais como quais foram os deputados autores da proposta. Usualmente apenas o nome do primeiro deputado a assinar a proposta é disponibilizado.

77 Consideramos apenas os dispositivos cuja autoria foi do poder executivo ou legislativo estadual. Os 5 dispositivos de autoria das Câmaras Municipais, 8 de iniciativa popular e 11 do poder judiciário são desconsiderados em razão de seu tamanho reduzido no total do emendamento. Muito embora não sejam insignificantes do ponto de vista teórico.
} 
Legislativo sobre o Poder Executivo de $83 \%$ quando consideram os projetos de lei como um todo. As taxas são consideravelmente próximas, mas deve-se levar em consideração que no nosso caso tratamos de dispositivos de emenda constitucional enquanto os autores lidam com projetos de lei.

Essa dominância do Legislativo sobre o Executivo é ainda mais acentuada se considerarmos as diferenças encontradas entre as unidades federativas. O Gráfico 3.18 dispõe os resultados proporcionais encontrados. Do gráfico notamos que no geral - Legislativo apresenta considerável dominância sobre o Executivo, e se compararmos com o emendamento à Constituição Federal vemos que nos estados 0 Legislativo apresenta maior taxa de dominância, enquanto na União a relação é próxima da equivalência. No entanto, no caso da Bahia e de Pernambuco o Executivo é significativamente dominante. No caso da Bahia, dos 191 dispositivos de emenda promulgados, 151 (79\%) foram de autoria do Executivo, enquanto em Pernambuco, dos 263 dispositivos promulgados, 200 (76\%) foram de autoria do Executivo.

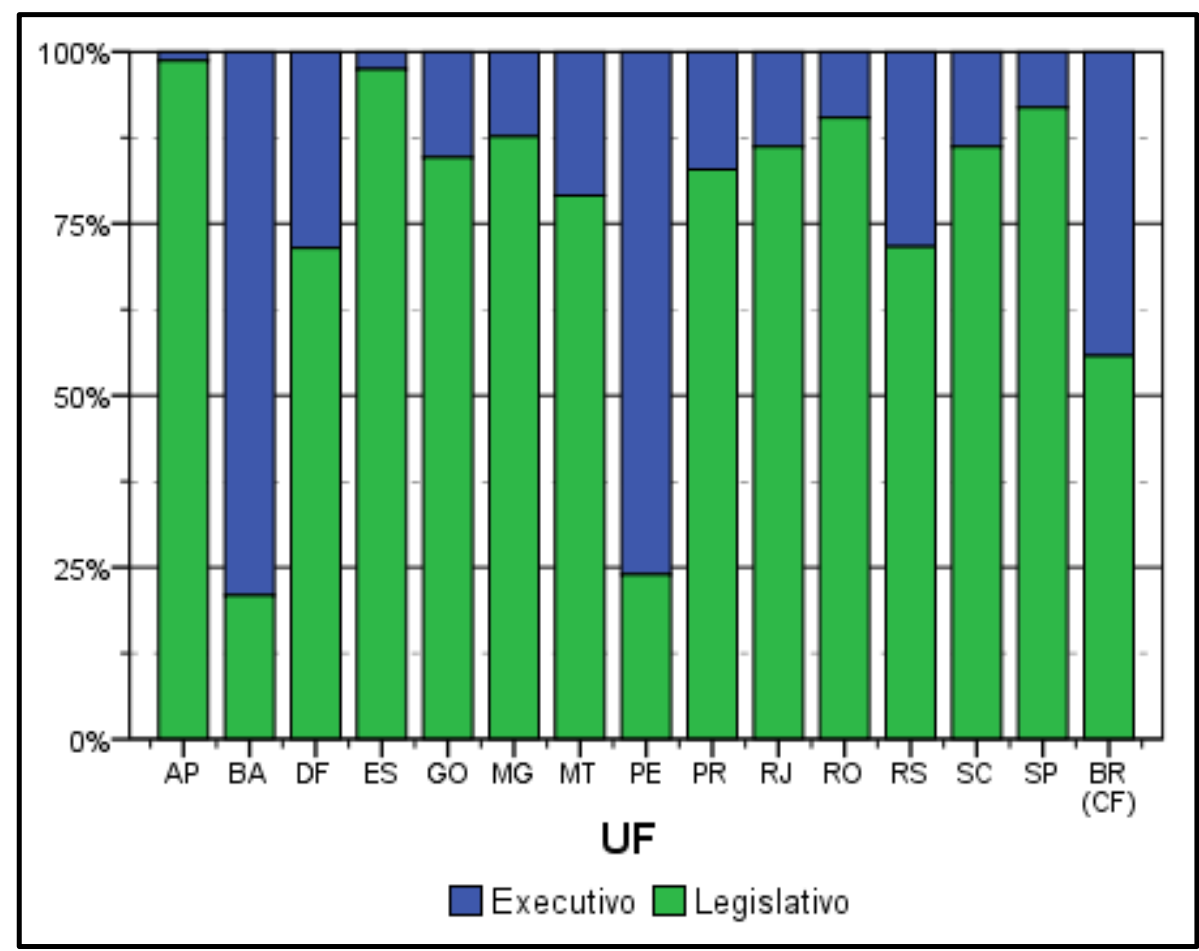

Gráfico 3.18 - Proporção de Dispositivos de Emenda por Ator Proponente em cada UF

Quando avaliados ao longo do tempo o ano de 1999 contém a maior quantidade de dispositivos de autoria do executivo promulgados. Neste ano foram aprovados 249 dos 1.018 (25\%) dispositivos de autoria do Executivo. Nos demais 
anos o Executivo foi autor de consideravelmente menos dispositivos aprovados e em nenhum deles apresentou concentração maior que $9 \%$ dos dispositivos de sua autoria. O Gráfico 3.19 apresenta os resultados encontrados. Há considerável variabilidade na aprovação de dispositivos ao ano por ator institucional. Enquanto o Executivo foi autor de uma média de 41 dispositivos de emenda constitucional ao ano, o Legislativo apresentou média de 161 dispositivos. Do gráfico notamos que no ano de 1999 o Poder Executivo foi autor de mais dispositivos que o Legislativo, situação que também ocorre em 2007. No emendamento Federal os dispositivos de autoria do Executivo se concentram majoritariamente em 1998 e 2003. No primeiro por conta das emendas 19 e 20, responsáveis pela reforma Administrativa e da Previdência, no segundo são as emendas 41 e 42 , da reforma tributária.

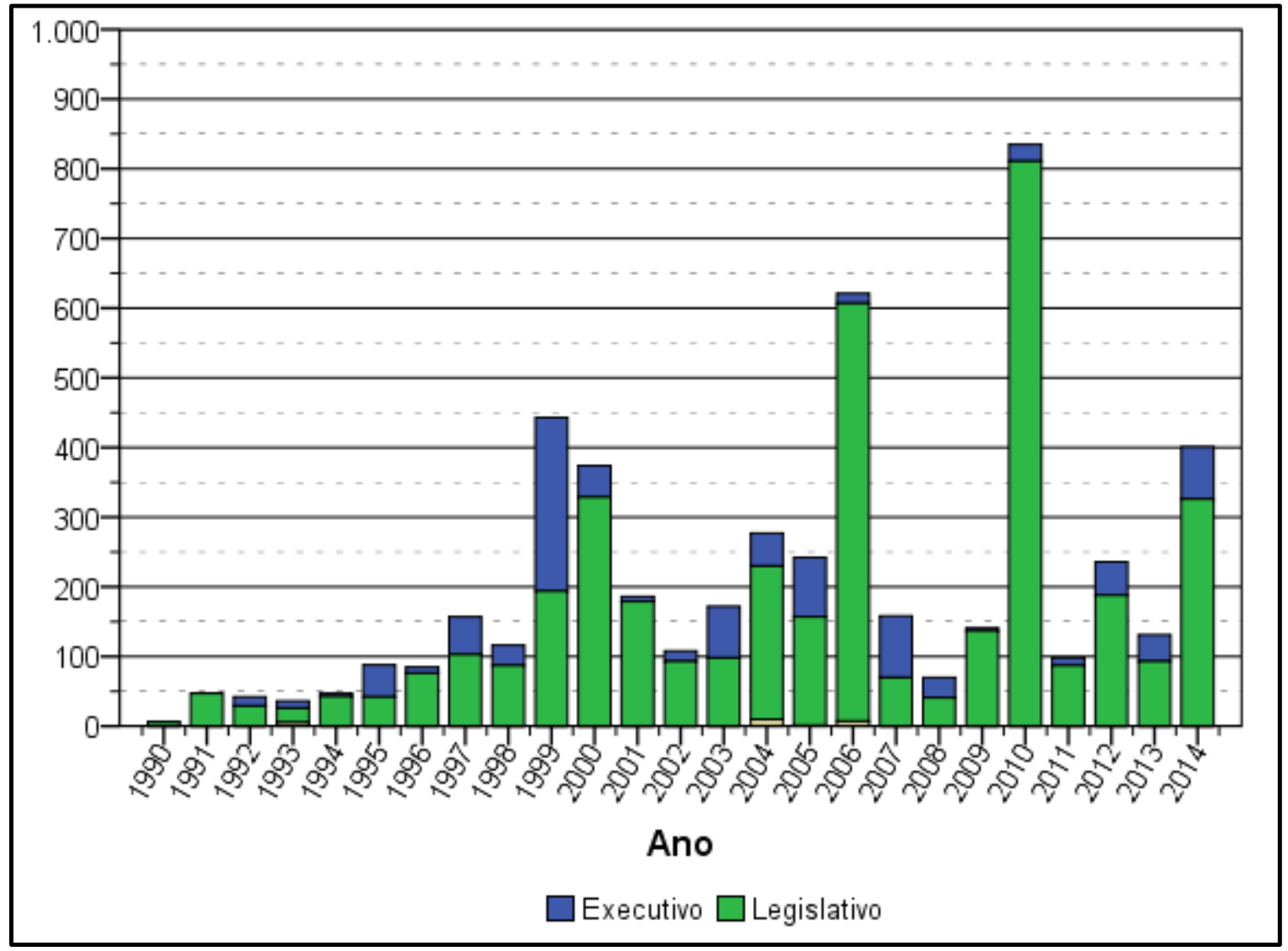

Gráfico 3.19 - Emendamento Anual, categorias por Origem Institucional

A quantidade elevada de dispositivos de autoria do Executivo promulgados em 1999 se dá em virtude da Bahia e de Pernambuco. Dos 260 dispositivos de autoria do Executivo promulgados neste ano, 223 (86\%) vieram desses estados, no caso da Bahia temos a EC 7, com 105 dispositivos e em Pernambuco as emendas 15, 16 e 
19, que totalizam 118 dispositivos $^{78}$. A EC 7 da Bahia e a EC 16 de Pernambuco são emendas responsáveis pela atualização das Constituições Estaduais em virtude da reforma da Administração Pública e Previdência introduzidas pelas emendas 19 e 20 da Constituição Federal, cuja autoria também foi do Poder Executivo.

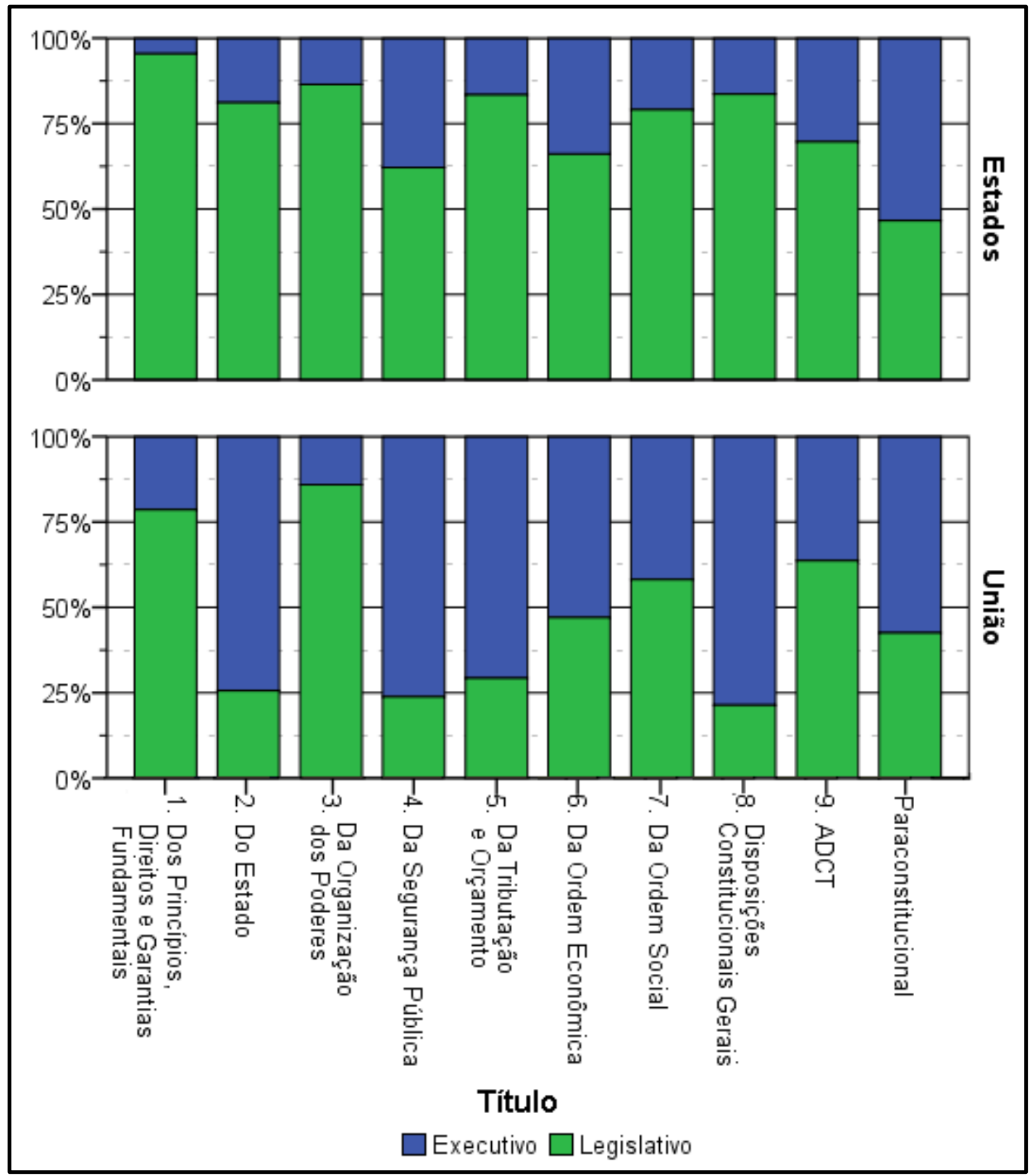

Gráfico 3.20 - Participação dos Atores Institucionais no Emendamento por Título, total Estadual e Federal

${ }^{78}$ A EC 7 representa $70 \%$ do emendamento com autoria do Executivo na Bahia e $53 \%$ do total de dispositivos de emenda deste estado. No caso de Pernambuco, a EC 15 contém 3 dispositivos e a EC 19 contém 1, os outros 114 pertencem à EC 16. Com 115 dispositivos esta emenda representa $58 \%$ do emendamento de autoria do Executivo e $43 \%$ do emendamento total de Pernambuco, 
Com base nas informações levantadas acerca das classificações dos dispositivos, o Gráfico 3.20 apresenta a relação proporcional, ou a dominância, entre os poderes dentro de cada Título. Do gráfico vemos que os Legislativos estaduais apresentam dominância maior que 50\% em 9 dos 10 Títulos encontrados. Embora haja variabilidade nesta proporção, o Executivo só apresenta maior autoria relativa de dispositivos Paraconstitucionais. Mas, dos dados apresentados temos que estes Títulos são consideravelmente menos emendados que os Títulos 2 e 3 . Portanto a diferença nos valores absolutos reduz a importância da maior autoria do Executivo neste. Em sentido contrário, no emendamento Federal o Executivo é autor de mais que $50 \%$ dos dispositivos em 6 dos 10 Títulos $^{79}$.

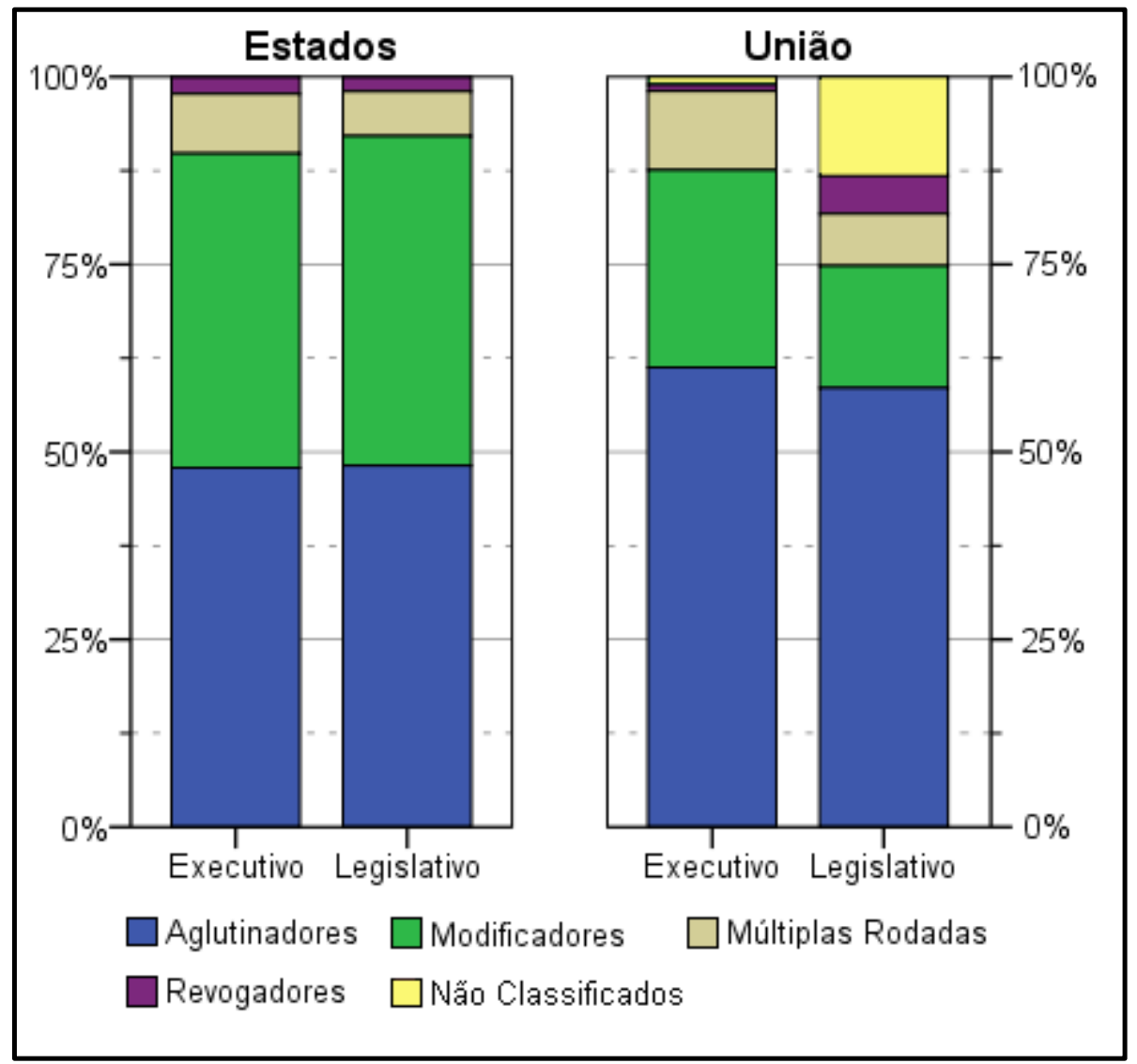

Gráfico 3.21 - Tipo de Emendamento por Ator Institucional, total Estadual e Federal

Quando consideramos como cada ator institucional se relaciona com a natureza do emendamento, isto é, de que forma o Poder Executivo e Legislativo alteram as Constituições, não encontramos qualquer diferença significativa entre os

\footnotetext{
${ }^{79}$ Nos Títulos 2, 4, 5, 6, 8 e Paraconstitucionais o Executivo é autor de mais de 50\% dos dispositivos, nos Títulos 1, 3, 7 e 9 a dominância é do Legislativo, mas apenas nos Títulos 1 e 3 está é marcante.
} 
Poderes. Dos dispositivos de emenda constitucional que cada poder é autor, a proporção entre aglutinadores, modificadores e revogadores é virtualmente igual. Isto é, o Executivo e o Legislativo Estadual se utilizam de acréscimos, modificações e revogações de forma quase idêntica. Em contrapartida no Emendamento Federal o Executivo se utiliza mais de modificações enquanto o Legislativo opta por aglutinações e revogações ${ }^{80}$.

De outra forma, quando consideramos a proporção de cada tipo de emendamento por autor, isto é, qual fração dos dispositivos aglutinadores é de autoria do executivo, e assim por diante, encontramos que o Legislativo apresenta dominância de pelo menos $75 \%$ em todos os tipos. Já no cenário Federal o Legislativo é dominante apenas nos revogadores. Isto é, seja em termos absolutos ou relativos o Executivo Estadual possui papel reduzido na autoria das emendas promulgadas quando consideramos a totalidade das Constituições Estaduais cujos dados estavam disponíveis. As duas exceções são a Bahia e Pernambuco, em que o Executivo é

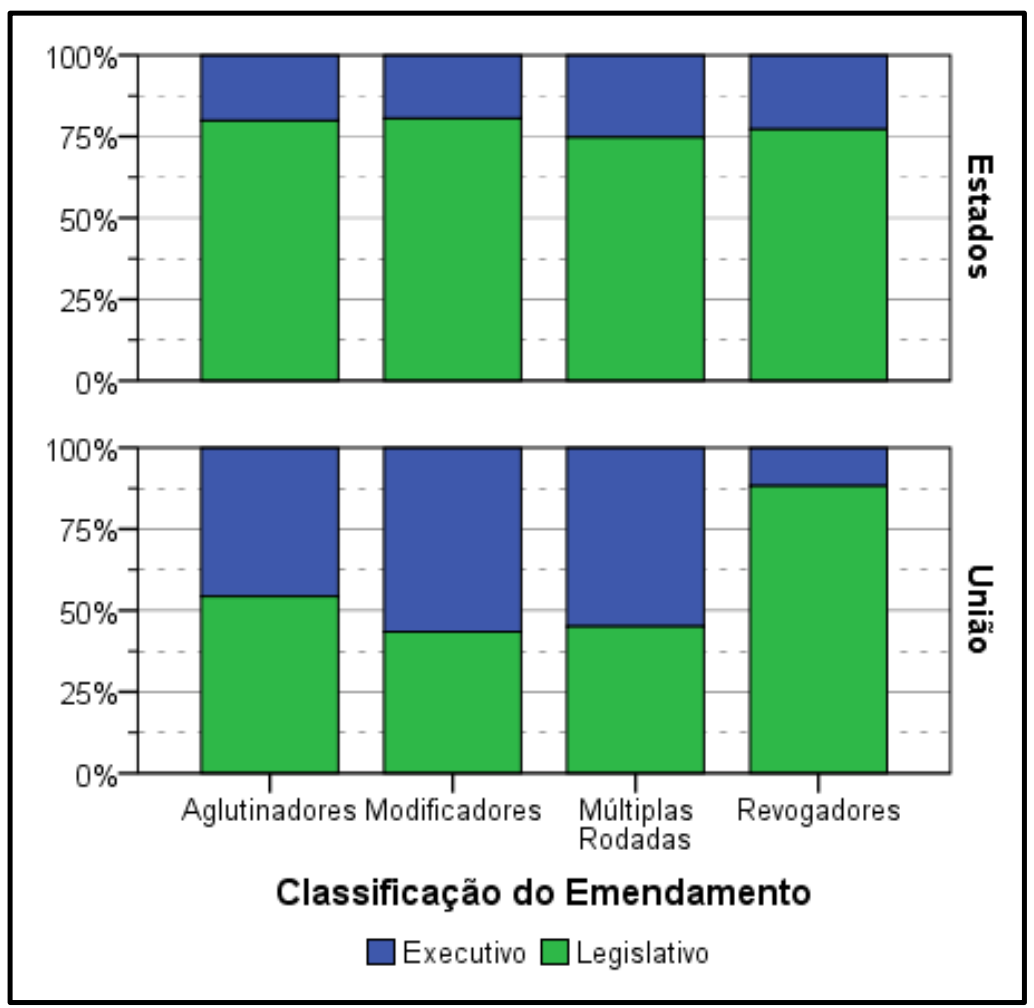

Gráfico 3.22 - Proporção dos Atores Proponentes por Tipo de Emendamento, total Estadual e Federal

\footnotetext{
${ }^{80}$ No Gráfico 3.21 essa diferença não é observável para o caso da União em virtude dos dispositivos não classificados serem de autoria exclusiva do Legislativo, portanto a afirmação é baseada no dado até 2010. No entanto isso significa que de 2010 a 2015 apenas o Legislativo foi autor de Emendas à Constituição Federal.
} 
autor de parcela significativa do emendamento, no entanto isso ocorre por consequência de uma emenda extensa em cada, cujo tema é a reforma Administrativa e da Previdência.

\subsection{Impacto do emendamento sobre o texto original}

Com a decomposição do texto das Constituições Estaduais Originais encontramos o total de 32.875 dispositivos, o que significa que as Constituições Estaduais foram promulgadas com uma média de 1.265 dispositivos cada. Do levantamento e decomposição das emendas às Constituições Estaduais promulgadas entre 1989 e 2014 identificamos 9.628 dispositivos de emenda, portanto os Estados promulgaram uma média de 370 dispositivos de emenda. Com isso a extensão do emendamento estadual agregado é cerca de 1/3 (29\%) da extensão das Constituições Estaduais originais. No mesmo período foram promulgados 1.117 dispositivos de Emenda à Constituição Federal, cuja extensão do Texto Original é de 1.854 dispositivos, ou seja, a extensão do emendamento federal é aproximadamente 3/5 (61\%) da extensão da Constituição promulgada em 1988. Desse modo, se as Constituições Estaduais apresentam, em média, 2/3 (68\%) da extensão da Constituição Federal, o emendamento estadual médio é apenas 1/3 (33\%) do emendamento federal. Portanto, o emendamento estadual tem se dado em nível inferior ao federal, quando a comparação se faz nestes termos.

No período avaliado os estados aglutinaram 4.387 dispositivos, uma média de 169 dispositivos por Constituição Estadual. Por meio de 217 dispositivos revogadores, ou uma média de 9 dispositivos revogadores por estado, foram retirados das Constituições Estaduais o total de 1.331 dispositivos, em média 51 dispositivos revogados de cada Constituição Estadual. Com isso, o crescimento líquido foi de 3.056 dispositivos, um aumento médio de 118 dispositivos em cada Constituição. Portanto, o Texto Original das Constituições Estaduais aumentou em média 10\% no período avaliado ${ }^{81}$. Esse aumento se deu na ordem de 4,5 dispositivos ao ano.

\footnotetext{
${ }^{81}$ O maior crescimento observado foi na Constituição de Roraima, com aumento de $26 \%$ de seu Texto Original, de 610 dispositivos para 770 dispositivos. O menor crescimento foi observado na Paraíba, cujo texto apresentou redução de $2 \%$ na extensão, de 1555 para 1522 dispositivos.
} 
Considerado o período de 1988 a 2010, para o qual dispomos de informação sobre seu emendamento, a Constituição Federal recebeu 656 novos dispositivos e revogou 80, um crescimento de 576 dispositivos, que significa um aumento de 1/3 (31\%) no Texto Original. Portanto, no intervalo de apenas 20 anos a Constituição Federal aumentou não só em termos absolutos, mas também proporcionais, significativamente mais do que as Constituições Estaduais o fizeram em um intervalo de 26 anos, seja em média ou quando consideradas individualmente.

No mesmo período a União modificou 229 dispositivos em primeira rodada e 91 em duas ou mais ${ }^{82}$, um total de 320 modificações. Assim, aproximadamente 17\% dos dispositivos do texto original foram modificados entre 1988 e 2010 . No intervalo entre 1989 e 2014 observamos a modificação de 4.172 dispositivos das Constituições Estaduais em primeira rodada e 748 em duas ou mais rodadas ${ }^{83}$, para o total de 4.920 modificações nas Constituições Estaduais. Em média os estados modificaram 160 dispositivos em primeira rodada, 29 em duas ou mais, portanto 189 no total ${ }^{84}$. Isso significa que no período os estados modificaram aproximadamente ${ }^{85} 15 \%$ de seus textos constitucionais originais.

Ao compararmos os períodos vemos então que as Constituições Estaduais apresentaram, em média, um pouco menos de modificações que a Constituição Federal, seja em primeira rodada ou múltiplas, em termos médios ou proporcionais. Todavia, no emendamento estadual observamos maiores sequências de emendamento sobre emendamento. Isto é, apenas no emendamento estadual encontramos modificadores de quarta e quinta rodada e uma revogação que poderia ser considerada de quinta rodada ${ }^{86}$. Mas estamos comparando dois intervalos distintos, ao restringir os dados estaduais para o mesmo intervalo avaliado no

\footnotetext{
8285 modificadores de segunda rodada e 6 de segunda rodada.

${ }^{83}$ Destes 635 foram de segunda rodada, 99 de terceira rodada, 12 de quarta e 2 de quinta rodada.

${ }^{84}$ A maior modificação é observada em Goiás, que altera cerca de $35 \%$ (428 de 1.189 dispositivos) de seu texto original, enquanto a menor modificação é observada no Rio Grande do Norte, que modifica menos que $3 \%$ de seu texto original ( 29 de 971 dispositivos).

${ }^{85}$ A porcentagem de modificação é sobrestimada já que comparamos as modificações com o Texto Original, não consideramos o caráter dinâmico das adições ao ao longo do tempo.

${ }^{86}$ Embora não tenhamos feito esta discriminação ao longo do texto e os revogadores de mais de uma rodada foram considerados apenas como revogadores, observamos um dispositivo revogador em quinta rodada. Este, encontrado na EC 75, revoga o Art. 278 da Constituição do Amazonas, que fora acrescentado pela EC 1 e posteriormente modificado pelas ECs 54,57 e 60 . Em caso análogo ao do Ceará, o Art. 278 da Constituição do Amazonas versa sobre a remuneração vitalícia dos Governadores do estado.
} 
emendamento Federal, isto é, até o ano de 2010, o resultado é que em média os estados modificam ainda menos dispositivos que a Constituição Federal, tanto em média quanto em termos proporcionais.

Assim não só os estados possuem constituições menos extensas que a Constituição Federal, mas desde sua promulgação também foram menos alteradas. Além de apresentarem menor crescimento, no período também foram menos modificadas, muito embora apresentem maiores cadeias de emendamento sobre emendamento. Então mesmo quando consideramos o intervalo maior de dados estaduais, o emendamento às Constituições Estaduais é significativamente inferior, estas cresceram menos e modificaram menos seus textos. No caso do emendamento estadual há equivalência entre acréscimos e modificações de dispositivos, já no caso do emendamento Federal encontramos a primazia dos acréscimos. Assim, mesmo que no emendamento às Constituições Estaduais a modificação do texto constitucional seja um mecanismo proporcionalmente mais utilizado que no emendamento federal, aquelas ainda são menos modificadas.

A segunda emenda à Constituição Federal, promulgada em 25 de agosto de 1992, inaugura um tipo de dispositivo constitucional que apenas pode ser observado nas próprias emendas. Os dispositivos Paraconstitucionais, identificados por Arantes e Couto (2009), possuem caráter constitucional já que são introduzidos no ordenamento jurídico por meio de emendas constitucionais, no entanto não são encontrados nos textos constitucionais em si, mas apenas nas próprias emendas constitucionais. No emendamento federal, entre 1988 e 2014, encontramos 150 dispositivos de emenda considerados paraconstitucionais, cerca de $13 \%$ do processo de emendamento à Constituição Federal (em média 6 dispositivos ao ano). Entre 1988 e 2010 foram identificados 127, dos quais 109 foram aglutinadores, 15 modificadores e 3 revogadores (que revogaram 14 dispositivos paraconstitucionais). Se o crescimento total da Constituição Federal, até 2010, foi de 576 dispositivos, os dispositivos paraconstitucionais representam então 17\% deste crescimento.

De forma análoga ao emendamento federal, nas emendas às Constituições Estaduais também identificamos dispositivos paraconstitucionais. O estado que inaugura este fenômeno é o Maranhão, em sua EC 9, promulgada em 25 de Março 
de 1993. Até 2014 apenas quatro estados ${ }^{87}$ não promulgaram nenhum dispositivo desta natureza, os demais promulgaram pelo menos 1 dispositivo deste tipo. No total observamos 223 dispositivos paraconstitucionais no emendamento estadual, o que significa uma média de 9 dispositivos por estado (0,35 dispositivos por estado por ano). Foram 212 aglutinadores, 5 modificadores e 4 revogadores (que revogaram 10 dispositivos). Ou seja, os dispositivos paraconstitucionais representam $7 \%$ do crescimento.

\subsection{Conteúdo do emendamento}

Os dispositivos paraconstitucionais, por não existirem no texto constitucional, são os únicos que não podem ser localizados e identificados em algum agrupamento temático. Mas, em consequência dessa própria característica única identificamos esses dispositivos como pertencentes a um décimo Título constitucional próprio. Portanto, se nas Constituições originais identificamos nove Títulos e com isso localizamos os dispositivos constitucionais, no emendamento o procedimento foi o mesmo, mas com a adição de um Título que aparece exclusivamente no emendamento.

O emendamento estadual se concentra majoritariamente nos Títulos 2 e 3 e com exceção do Título 7 , os demais Títulos contém quantidade marginal de dispositivos. O Título 2, "Do Estado", é composto principalmente por dispositivos cujo tema tratado é Administração Pública (servidores civis e militares) e questões municipais, como fiscalização orçamentária e organização do executivo e legislativo municipal. O Título 3, "Da Organização dos Poderes", possui quatro grandes temas, o poder Legislativo, o Executivo, o Judiciário e as Funções Essenciais à Justiça. Já o Título 7, "Da Ordem Social", agrega principalmente os temas relacionados à saúde, previdência social, educação e proteção às minorias.

Ao considerarmos a incidência proporcional do emendamento em cada um dos dez Títulos dentro de cada estado, identificamos um perfil geral que indica maior frequência de emendamento estadual sobre os Títulos 2, 3 e 7, no entanto a proporção

\footnotetext{
${ }^{87}$ Espírito Santo, Paraná, Rio Grande do Norte e Sergipe.
} 
encontrada em cada estado varia pouco para os Títulos 2 e 3 . Isto é, uma parcela equivalente do emendamento ocorrido em cada estado incidiu sobre esses Títulos, enquanto que os demais Títulos foram emendados, proporcionalmente, de forma um tanto quanto distinta entre os estados.

No caso do emendamento Federal, a incidência, proporcional, sobre os Títulos se mostra significativamente distinta daquele perfil encontrado no emendamento estadual. O emendamento Federal não se concentra sob apenas dois Títulos, e ao contrário do caso estadual, os dispositivos paraconstitucionais e do ADCT são altamente emendados. Os Títulos 2 e 3 também estão entre os mais emendados na Constituição Federal, todavia em proporções bem inferiores quando comparados com o emendamento estadual. Assim, enquanto as emendas à Constituição Estadual se concentram em apenas dois Títulos, as emendas à Constituição Federal são mais bem distribuídas entre os demais temas da constituição.

Pela aplicação completa da $\mathrm{MAC}^{88}$ não só os textos constitucionais são decompostos em dispositivos, mas cada um desses dispositivos pode ser classificado e identificado segundo diferentes características. Uma das características que utilizamos foi a identificação do impacto quantitativo de um dispositivo de emenda, isto é, se acrescenta, modifica ou revoga um dispositivo constitucional. Outra classificação consiste em uma abordagem mais qualitativa dos dispositivos. Grosso modo, a metodologia permite que um dispositivo seja identificado como uma política pública constitucionalizada (policy) ou um dispositivo propriamente constitucional (polity).

Em virtude da quantidade de dispositivos estaduais não foi possível ainda classifica-los segundo estas categorias, tal como Arantes e Couto $(2006,2012)$ fizeram para Constituição Federal e suas emendas. Como a padronização dos Títulos das Constituições Estaduais resultou em uma organização constitucional semelhante àquela encontrada na Constituição Federal, utilizamos as proporções de polity/policy encontradas nos Títulos federais para avaliar o emendamento estadual.

Com base na classificação dos dispositivos da Constituição Federal temos que o emendamento estadual se concentra em Títulos com elevada presença de

${ }^{88}$ Ver Arantes e Couto (2002; 2006; 2009) 
polities, qual seja, os Títulos 2 e 3. No entanto, com a classificação do emendamento Federal, realizada por Arantes e Couto (2012), vemos que dos dispositivos de emenda que incidem sobre o Título 2 , aproximadamente $82 \%$ são policies, enquanto dos que incidem sobre o Título 3 , apenas $22 \%$ tem caráter de policy. Desse modo se replicarmos estes valores para todos os dispositivos do emendamento estadual, podemos estimar que $58 \%$ do emendamento estadual pode ter caráter de política pública constitucionalizada, enquanto $42 \%$ seriam considerados dispositivos propriamente constitucionais. No caso do emendamento Federal $67 \%$ dos dispositivos apresentam caráter de policy, enquanto $43 \%$ são classificados como polity.

As emendas à Constituição Federal, promulgadas até 2010, contém dispositivos que são principalmente de políticas públicas, este cenário se repete no caso estadual, embora com menor intensidade. Mas devemos ressaltar que a classificação não foi aplicada aos dispositivos estaduais, seja de emenda ou das Constituições originais. Nesse sentido, por mais que exista semelhança entre o emendamento federal e o estadual, ainda não podemos afirmar categoricamente que essa proporção se repete nos estados.

O critério de padronização que aplicamos localizou os dispositivos constitucionais em títulos, capítulos e sessões. Desse modo, a fim de melhor identificar quais temas são tratados nos Títulos 2, 3 e 7 avaliamos a incidência dos dispositivos também sobre as seções e capítulos desses Títulos ${ }^{89}$.

No Título 2 o tema com maior incidência de emendamento é a Administração Pública, mais especificamente a Seção sobre os Servidores Civis, seguido pela Fiscalização Financeira e Orçamentária dos Municípios. No Título 30 maior emendamento é sobre o poder Legislativo, principalmente sobre o Controle Financeiro e Orçamentário Estadual, Funcionamento da Assembleia e Atribuições e Competências da Assembleia Legislativa ${ }^{90}$. Em seguida temos poder Judiciário e as Funções Essenciais à Justiça, cujo emendamento é distribuído de forma equivalente entre seus temas; por fim o poder Executivo, que apresenta incidência marginal de

\footnotetext{
89 Não utilizamos a classificação em todo o emendamento uma vez que se compararmos Títulos são 10 categorias, ao utilizarmos até o nível de seção são 52.

90 Todas as Seções do Poder Legislativo são consideravelmente emendadas, apenas o poder Legislativo concentra $45 \%$ do emendamento no Título 3, e a seção que destacamos contém $30 \%$ do emendamento sobre este poder.
} 
emendamento. No Título 7, o emendamento incide majoritariamente sobre a Previdência Social e sobre a Educação.

Considerando, portanto, a divisão temática do emendamento estadual, vemos que este incide principalmente sobre os Servidores Civis da Administração Pública, Fiscalização Financeira e Orçamentária municipal e estadual, Tribunal de Justiça, Ministério Público, Procuradoria, Defensoria Pública e finalmente sobre a Previdência e Educação. Apenas essas nove seções destacadas concentram $40 \%$ de todo o emendamento observado em nível estadual. Não aplicamos a padronização no nível de seções e capítulos na Constituição Federal ou no emendamento desta, todavia, em virtude da menor extensão (quando considerada a totalidade do emendamento), podemos identificar algumas emendas à Constituição Federal e seus temas. Em especial as ECs 19, 20, e 45.

Com relação às emendas 19 e 20, ambas promulgadas em 1998, já destacamos a relação explícita que parte do emendamento estadual mantém com as mesmas. Essas emendas trataram principalmente da Administração Pública e da Previdência, respectivamente. Segundo Arantes e Couto (2009), essas emendas, identificadas como a Reforma Administrativa e a Reforma Previdenciária, estão entre as maiores emendas à Constituição Federal já promulgadas, a primeira com 99 dispositivos (58\% dispositivos de policy), a segunda com 100 dispositivos (90\% dispositivos de policy). Ao observar o emendamento sobre as seções da Administração Pública e da Previdência no emendamento estadual, verificamos sua concentração no ano de 1999, quando alguns estados promulgam elevado número de dispositivos sobre esses temas, e mesmo após 1999 encontramos outros estados com picos de emendamento sobre essas seções, o que sugere reformas administrativas e da previdência realizada pelos estados após a reforma na Constituição Federal ${ }^{91}$.

A EC 45, promulgada dia 30/12/2004, é a maior emenda à Constituição Federal promulgada. Esta conta com 158 dispositivos (15\% dispositivos de policy) e é identificada como Reforma do Judiciário (Arantes e Couto, 2009). Nesta emenda 143 dos 158 incidem sobre o Título 3 da Constituição Federal, mais especificamente sobre

\footnotetext{
${ }^{91}$ Com exceção de Tocantins. Este apresenta emendamento elevado sobre essas seções em 1998 por meio da EC 7. Esta promulgada em 15/12/1998, cuja ementa indica que esta emenda adapta a Constituição do estado às alterações da Constituição Federal. No mesmo dia também é promulgada a emenda à Constituição Federal responsável pela reforma administrativa.
} 
os Capítulos que tratam do poder Judiciário e Das Funções Essenciais à Justiça. No emendamento estadual encontramos 1.525 emendas incidindo sobre essas seções, de 1989 até o final de 2004 foram 458 dispositivos promulgados, entre o começo de 2005 e o final de 2014 foram 1.067 dispositivos (70\%), concentrados nos primeiros anos deste intervalo.

O emendamento estadual é composto majoritariamente por dispositivos que incidem sobre os Títulos 2 e 3, e embora a quantidade de dispositivos de emenda promulgados por cada estado apresente variação elevada, ao observamos a composição proporcional do emendamento vemos que os Títulos 2 e 3 são também aqueles com menor variação proporcional. Assim, esses Títulos não só contém a maior parte do emendamento estadual, como apresentam proporção relativa equivalente entre os estados. Dentro desses Títulos os temas mais frequentemente emendados são os identificados com emendas à Constituição Federal, sendo que é após a promulgação dessas emendas federais que observamos as maiores quantidades de dispositivos de emenda às Constituições Estaduais promulgados sob o mesmo tema. Mesmo que o perfil de emendamento estadual seja diferente do federal, a maioria do emendamento estadual parece estar relacionada com 0 emendamento federal, o que explicaria também a baixa variação no emendamento de tais Títulos entre os estados.

De forma geral a autoria do emendamento estadual é das Assembleias Legislativas. Em apenas dois estados o poder Executivo foi autor de maior quantidade de emendas. Na Bahia, onde o executivo é autor de 149 dos 187 dispositivos de emenda promulgados, e em Pernambuco ${ }^{92}$, onde o Executivo é autor de 176 dos 230 dispositivos. Esses são os únicos dois estados em que o poder Executivo é autor de mais que $30 \%$ dos dispositivos de emenda promulgados. Em ambos os casos não só o emendamento do Executivo se concentra principalmente sobre o ano de 1999, como também versam sobre o mesmo assunto, a Reforma Administrativa e a Reforma Previdenciária ${ }^{93}$.

\footnotetext{
92 Vale destacar que nos dois casos, os governadores eleitos no ano anterior (1998) contaram com votações maciças nas urnas, $70 \%$ e $65 \%$ respectivamente, e lograram uma base parlamentar na Assembleia da ordem de $70 \%$ e $43 \%$ respectivamente.

${ }^{93} \mathrm{Na}$ Bahia $70 \%$ dos dispositivos de autoria do Executivo são promulgados neste ano, em Pernambuco essa proporção é de $60 \%$.
} 
Além do emendamento decorrente desses casos, os Executivos são autores mais frequentemente de dispositivos do ADCT e Paraconstitucionais. No entanto ao desconsiderar o caso da Bahia e de Pernambuco, o poder Executivo passa a ser pouco significativo em termos de autoria de emendas quando comparado com 0 Legislativo. Já no caso do emendamento federal vemos que o poder Executivo e o Legislativo são mais equivalentes. O Legislativo Federal assume autoria de pouco mais de $50 \%$ dos dispositivos promulgados.

Como resultado do emendamento estadual encontramos que desde 1989 as Constituições estaduais aumentaram ligeiramente de tamanho, e este aumento se apresenta em taxas crescentes ao longo do tempo, no entanto, as modificações do texto ainda são o mecanismo mais utilizado na alteração das Constituições Estaduais. Em contraste, o emendamento Federal é marcado por adição de novos dispositivos ao Texto Constitucional. Além de o emendamento estadual ser menos intenso que o emendamento federal, também encontramos indícios que parte significativa do emendamento estadual ocorre em decorrência do emendamento Federal, uma vez que após a promulgação de uma emenda à Constituição Federal encontramos elevação no emendamento estadual sobre o tema por ela tratado, especificamente sobre temas tratados nos Títulos 2 e 3 . Possivelmente, a maior extensão das emendas à Constituição Federal, relativas às três grandes reformas examinadas (Administrativa, Previdenciária e Judiciária) permite que esse reflexo seja observado, mas não podemos excluir a possibilidade de que isto também ocorra nos demais Títulos. Todavia, se o emendamento estadual reflete de alguma forma 0 emendamento Federal, quando consideramos os atores com capacidade de proposição que fazem uso desta prerrogativa, vemos que no caso estadual o Legislativo é fortemente dominante, já que elevada parcela de dispositivos promulgados são de emendas cuja autoria é das Assembleias Legislativas. 


\section{Determinantes do Emendamento Estadual}

A mudança constitucional é abordada como fenômeno na literatura sob diferentes perspectivas. Os estudos, majoritariamente empíricos, divergem tanto no que diz respeito ao próprio conceito de mudança constitucional quanto às suas causas e consequências. Segundo Lorenz (2012) a literatura de mudança constitucional carece de uma tipologia, de terminologia e de teoria geral. Como consequência dessa ausência de consenso não só variáveis equivalentes são operacionalizadas de formas distintas como também os estudos se concentram em casos que não dialogam entre si.

Nossa análise se depara exatamente com o cenário descrito. Podemos considerá-la um estudo de casos, já que o foco é sobre o emendamento às Constituições Estaduais promulgadas pós-1989, sem falar que nossa metodologia operacionaliza a análise deste emendamento de forma incomum se comparada à literatura mainstream. Todavia não temos a pretensão de desenvolver uma teoria geral do emendamento constitucional, mas sim explorar e possivelmente identificar fatores que se relacionam com o padrão de emendamento nos estados brasileiros e possivelmente explicar o cenário com o qual nos deparamos. Buscamos também abordar hipóteses frequentemente encontradas na literatura de mudança constitucional e, na medida do possível, compará-las.

O emendamento pode ser classificado como um processo dinâmico ou estático. No primeiro caso o fenômeno é observado ao longo de intervalos específicos de tempo, no segundo é feito um recorte e a variável tempo de certo modo fica de certo modo congelada. Acreditamos que o emendamento seja fundamentalmente dinâmico, isto é, trata-se de um processo no qual a alteração do texto constitucional ocorre de forma contínua ao longo do tempo. Diferentemente da promulgação da Constituição, que representa um evento isolado, o emendamento é um processo afetado não só por características presentes e expectativas futuras, mas também por situações passadas, que são retroalimentadas todas as vezes que os atores percebem a necessidade e reúnem as condições de alteração da constituição. 
A fim de avaliar a heterogeneidade do emendamento nas Constituições Estaduais optamos por modelos estáticos mais simples, mesmo que essa opção vá contra nosso argumento anterior. Embora nossa metodologia de análise tenha avançado mais do que a média da literatura no que diz respeito à capacidade de captar o dinamismo do emendamento constitucional (quando identificamos, por exemplo, dispositivos que se sobrepõem por meio de emendamento sobre emendamento), as hipóteses aqui aventadas e os dados disponíveis para testá-las não nos permitem, por ora, operar com modelos mais sofisticados. Assim, optamos por modelos estáticos e delimitamos os intervalos que compõem o objeto de análise. Para tanto selecionamos três organizações temporais distintas dos dados. O emendamento ao ano, por legislatura e por período, todos os três para cada unidade federativa. Na primeira forma observamos o emendamento anual ${ }^{94}$ de cada unidade federativa, na segunda, contabilizamos o emendamento de cada unidade federativa em cada legislatura pós-1989; por fim, na abordagem por período agregamos o total do emendamento no intervalo de interesse, no caso de 1989 a 2014.

No emendamento estadual observamos duas características importantes. Por um lado, os estados emendam suas Constituições em intensidades distintas, não parecendo haver um padrão na quantidade de dispositivos de emenda promulgados. Por outro, apesar dessa heterogeneidade, o emendamento estadual apresenta uma divisão temática semelhante. Mesmo que em quantidades absolutas diferentes, verificamos que os estados dedicam proporções semelhantes do emendamento aos mesmos temas. Portanto, mesmo que haja heterogeneidade no tamanho e na intensidade do emendamento este se divide de forma proporcionalmente equivalente entre os diferentes temas.

A fim de explicar a diversidade no emendamento estadual, partimos de alguns pressupostos que permitem simplificar a análise. Nosso interesse é o processo de emendamento como um todo. Deste modo, consideramos que as características individuais, ou preferências, dos Governadores, Constituintes, Deputados estaduais e demais atores envolvidos no processo de emendamento são aleatórias e não

\footnotetext{
${ }_{94}^{94}$ Quando organizamos o emendamento por ano nos deparamos, fundamentalmente, com uma série temporal, todavia adotamos o pressuposto - não crível - de que as observações são independentes a fruto de simplificação.
} 
observáveis ${ }^{95}$, de forma que seu possível efeito sobre o emendamento é também aleatório. Outro pressuposto essencial para a análise se dá sobre a relevância das Constituições Estaduais. Não há estudo que quantifique ou qualifique o papel das Constituições Estaduais no Brasil, no entanto é comum o argumento de que estas são vazias de significado e de relevância política, consistindo em meras cópias da Constituição Federal (SOUZA, 2005). Além da ausência de mensuração também não há teoria geral ou abordagem sistemática dessas Cartas que permitam afirmar que são documentos vazios. Comprovar (ou refutar) os impactos exercidos pelos textos Constitucionais Estaduais está fora de nosso escopo. Então como segundo pressuposto assumimos que as Constituições Estaduais importam ${ }^{96}$.

A partir da identificação da variabilidade no emendamento às Cartas de cada estado levantamos três conjuntos de hipóteses com o intuito de explicar - ou pelo menos explorar - os determinantes no processo de emendamento. No primeiro conjunto de hipóteses adotamos um ponto de vista contextual, pelo qual buscamos a possibilidade de associação entre o cenário de desenvolvimento regional (econômico ou social) e o emendamento constitucional. Em seguida abordamos o emendamento por meio das instituições, e por fim buscamos a possibilidade de associação do emendamento com variáveis de cunho mais político.

Antes de seguirmos com as análises e testes das hipóteses relevantes acreditamos que um esclarecimento acerca de nossa abordagem metodológica é necessário. Optamos por considerar o conjunto de Constituições Estaduais Brasileiras levantado como uma amostra de uma população de Constituições Estaduais. Ao optar por esta abordagem incorremos no problema de viés de seleção, já que não só a amostra não foi aleatória como também não é representativa. Sendo assim os níveis de significância, embora calculados, apresentam interpretação e aplicabilidade prejudicada ${ }^{97}$. Portanto o procedimento que utilizamos para a análise das hipóteses

\footnotetext{
95 O que não está longe da realidade, uma vez que é inviável levantar as preferências de cada indivíduo nesse contexto. Disso decorre que também não desenvolvemos modelos a fim de estimar ou aproximar de que modo tais preferências se organizam.

96 Observamos alteração intensa e constante ao longo do tempo nas Constituições Estaduais. Muito embora apenas a alteração do texto Constitucional não seja uma medida da relevância das Constituições Estaduais como instituição, é pouco crível que recursos seriam gastos para a intensa alteração de textos puramente simbólicos ou destituídos de importância (KINCAID, 1988).

${ }^{97}$ Caso nossos dados sejam considerados uma população os níveis descritivos ( $p$-valor) também são vazios de significado. Portanto independente do tratamento amostral a significância estatística ocupa lugar secundário na análise.
} 
não tem como base os níveis descritivos e significância estatística, mas sim a construção do argumento.

\subsection{Hipóteses Contextuais}

A associação do contexto econômico, ou variáveis estruturais, com a alteração constitucional é frequentemente encontrada na literatura (ELKINS; GINSBURG; MELTON, 2009; MONTENEGRO, 1995; NEGRETTO, 2012; TSEBELIS; NARDI, 2014). No entanto, a forma como essa relação é abordada apresenta significativa diferença. O contexto econômico pode ocupar a posição de variável dependente, independente ou de controle em relação ao emendamento constitucional. Não há consenso quanto à causalidade entre essas variáveis, tanto a economia pode causar alteração constitucional - já que esta, por exemplo, pode se alterar para se adequar às novas realidades econômicas - como a economia pode ser incentivada (ou desincentivada) mediante alteração das normas constitucionais, como as tributárias, as relativas a investimentos, recursos naturais ou segurança jurídica, dentre muitos outros.

Ao avaliar a relação entre o contexto econômico e o emendamento constitucional não é necessário assumir causalidade expressa, já que nossa pergunta é meramente se há relação observável, e não como se dá ou qual seria a intensidade de tal associação. Todavia adotamos o emendamento constitucional como variável dependente, isso porque não só nosso estudo se foca sobre o emendamento, mas também porque essa configuração é mais comumente encontrada na literatura, o que nos permite certa comunicação com modelos já estabelecidos.

Como uma primeira abordagem à pergunta proposta, qual seja, se há relação entre contexto econômico ou social e emendamento constitucional, temos as seguintes hipóteses:

H1: Emendamento Constitucional e desenvolvimento econômico variam em conjunto. 
H2: Emendamento Constitucional é mais intenso em sociedades mais heterogêneas.

A relação entre o Emendamento Constitucional e o desenvolvimento econômico pode não só tomar diferentes direções causais, mas também efeitos opostos. Mas esperamos efeitos marginais decrescentes, o que permite a existência de um limiar máximo do emendamento como função da economia. A argumentação causal não é trivial, ainda mais quando consideramos a falta de consenso na literatura acerca dos efeitos e relações dessas variáveis. Portanto, como primeiro passo nos limitamos a observar a existência de alguma relação estatística entre as variáveis, mesmo que com isso haja viés por omissão e possivelmente correlação espúria. Esperamos relação positiva entre fragmentação social e emendamento constitucional; neste caso, o argumento subjacente é que em sociedades mais social, econômica ou religiosamente heterogêneas espera-se não só maior Constituição, mas também maior alteração constitucional a fim de adaptar as diferentes demandas e solucionar possíveis conflitos (BJØRNSKOV; VOIGT, 2013).

Operacionalizamos o contexto econômico e social por meio de quatro variáveis. O PIB, PIB per capita, IDH e coeficiente de GINI. As duas primeiras, frequentemente encontradas na literatura, são unidades de medida amplamente utilizadas para medir a riqueza de uma região e em nosso modelo são indicadores do desenvolvimento. Já as últimas tem por objetivo captar elementos além da riqueza monetária. O IDH opera como um indicador de desenvolvimento social e o coeficiente de GINI opera como nosso único indicador de fragmentação.

Do Gráfico 4.1 vemos que quando consideramos as variáveis aos pares dificilmente surge algum padrão de associação observável. Quando formalizamos a associação entre as variáveis, os coeficientes de correlação ${ }^{98}$, embora pouco confiáveis, também não apresentam evidências de associação linear ou mesmo monotônica. Assim, não nos parece que a variação no contexto econômico de $1989^{99}$ é suficiente para explicar a heterogeneidade do emendamento.

Gráfico 4.1 - Gráficos de Dispersão entre Dispositivos de Emenda e Variáveis Contextuais

\footnotetext{
98 Ver Apêndice A.7

99 Utilizamos um ano específico como fonte dos dados contextuais para manter a simplicidade do modelo, com dados agregados por estado em vez de séries temporais ou painéis. Em específico o ano
} 


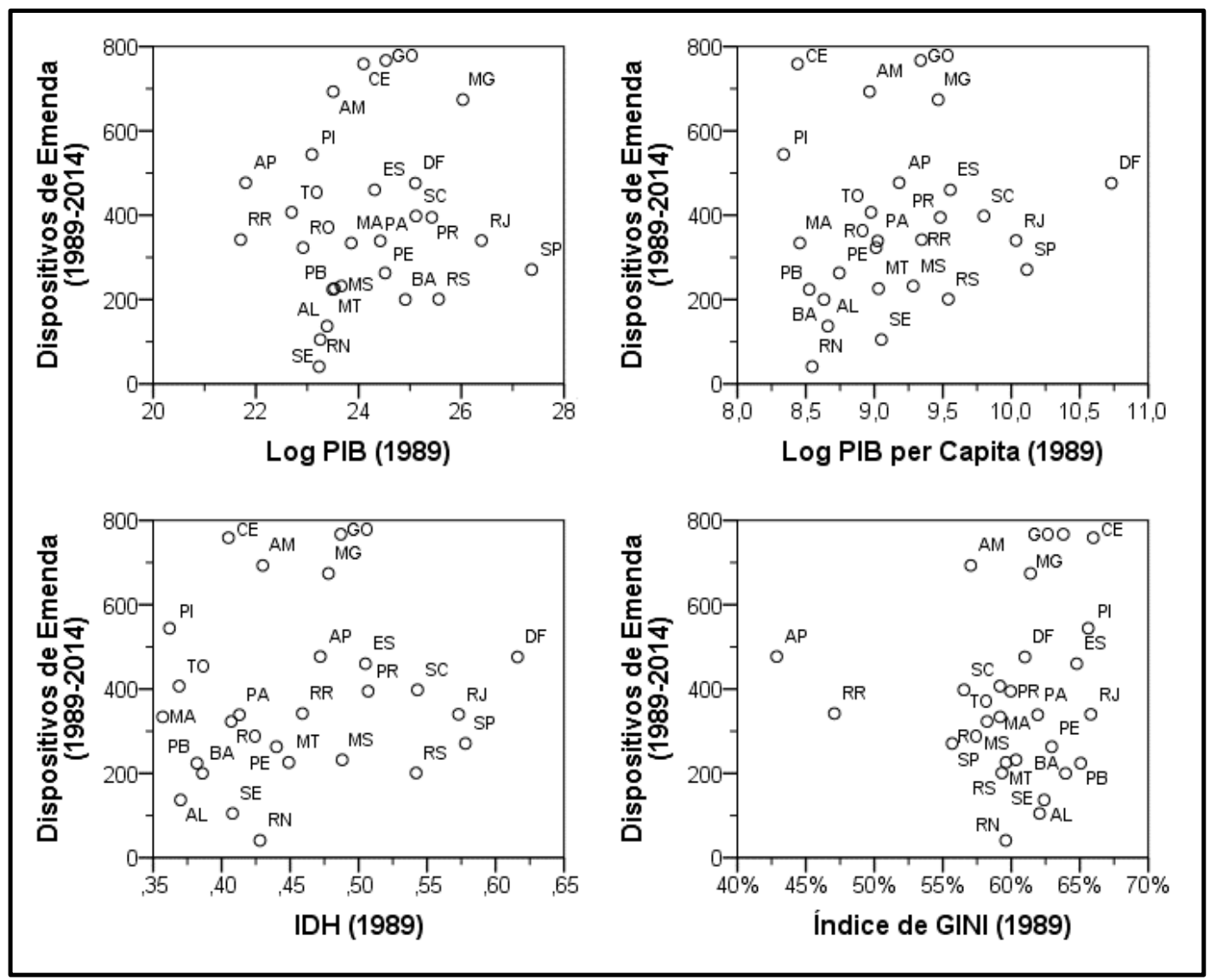

Esse resultado não implica que não exista alguma relação entre essas variáveis, especialmente em termos mais gerais, mas sim que não foi possível observá-la estatisticamente para o caso do emendamento estadual brasileiro. O que pode ser consequência não só de nossas simplificações, mas também das variáveis utilizadas e a forma como foram instrumentalizadas. Quando comparamos com os resultados encontrados na literatura vemos que Negretto (2012) e Bjørnskov e Voigt (2013) também não encontram evidências de associação entre as variáveis, mas devemos considerar também que os modelos utilizados são consideravelmente distintos, não só em termos de instrumentalização das variáveis, mas também de formalização da estrutura.

Sendo assim, no caso das Constituições Estaduais brasileiras não encontramos evidências de associação entre o emendamento constitucional e o

de 1989, ano de promulgação da maioria das Constituições Estaduais, a fim de manter a coerência com nosso pressuposto de que o emendamento é variável dependente. Contabilizamos o emendamento de 1989 a 2014, portanto as variáveis causais devem preceder as explicadas. Por fim, dada a falta de teoria geral ou consenso na literatura, o ano utilizado como base é frequentemente subjetivo e em diversos casos a escolha não é justificada ou mesmo não informada (MONTENEGRO, 1995; ELKINS ET. AL. 2009; GINSBURG, 2010). Quando optamos pelo ano de 1989 também permitimos o diálogo com parte da literatura que utiliza 0 ano de promulgação das Constituições (BJØRNSKOV E VOIGT, 2013; NEGRETTO, 2012). 
contexto econômico dentro do modelo proposto. Ainda que nossa abordagem seja limitada para o desenvolvimento de teorias gerais acerca do emendamento, acreditamos que representam um primeiro passo na compreensão do fenômeno no cenário estadual brasileiro. Guardadas as limitações apontadas, os indicadores utilizados na elaboração do Gráfico 4.1 permitem afastar - ou pelo menos não confirmar - as hipóteses de que o Emendamento Constitucional nos estados esteja associado ao grau de desenvolvimento econômico das unidades federativas ou que seja mais intenso em contextos mais heterogêneas.

Vale ressaltar que em para além das simplificações adotadas haveria diversas formas de refinar e estender a pesquisa. Desde uma abordagem teórica mais fundamentada, escassa na literatura, até a utilização de modelos mais complexos que definem o emendamento como fenômeno dinâmico, como séries temporais multivariadas e maior controle sobre possíveis variáveis omitidas correlatas, as hipóteses $\mathrm{H} 1$ e $\mathrm{H} 2$ aqui aventadas podem e devem ensejar novos e futuros testes.

\subsection{Hipóteses Institucionais}

Neste segundo conjunto de hipóteses nosso esforço é abordar o emendamento constitucional sob uma perspectiva institucional. Este tipo de abordagem é mais comumente encontrado na literatura de mudança constitucional e de forma geral associa o emendamento constitucional com regras e normas preestabelecidas. Sob essa perspectiva as instituições determinam de que forma os diferentes incentivos à alteração constitucional se manifestam como emendamento constitucional (LORENZ, 2012). Assim o arranjo institucional - fundamentalmente preestabelecido - é fator crucial na determinação do emendamento Constitucional.

Uma das instituições mais utilizadas a fim de explicar o emendamento constitucional é a rigidez constitucional. Contudo, o próprio conceito de rigidez constitucional não encontra consenso na literatura. Como vimos nos capítulos anteriores, encontramos grande variedade tanto nas definições do conceito de rigidez constitucional quanto nas formas adequadas de medi-la (LUTZ, 1994; LIJPHART, 
1999; ANCKAR \& KARVONEN; 2002; LORENZ, 2005; RASCH, 2008; NEGRETTO, 2012 GINSBURG \& MELTON, 2014). Se por um lado há diversidade na metodologia de construção do índice de rigidez, por outro parece haver consenso de que quanto maior a rigidez constitucional menor o emendamento. Esta relação opera principalmente por meio de um mecanismo direto e outro indireto ${ }^{100}$. Contudo devemos destacar que para Ginsburg e Melton (2014) a rigidez constitucional em si não desempenha papel relevante no emendamento, mas sim o que o autor chama de cultura de emendamento, hipótese ainda não suficientemente explorada. Ademais, Rasch (2003) aponta que a relação empírica entre emendamento e rigidez não é robusta o suficiente para as conclusões frequentemente encontradas na literatura.

A rigidez constitucional pode ser interpretada como uma medida dos custos subjacentes ao emendamento constitucional. Mesmo que haja diferença na metodologia utilizada para construir os diferentes índices, são as normas de proposição e aprovação de emendas que servem como base. Sabemos que no caso dos estados brasileiros as regras podem ser consideradas iguais, portanto a heterogeneidade no emendamento estadual não pode ser explicada pela rigidez constitucional $^{101}$. Todavia, não podemos estabelecer comparação com as hipóteses levantadas na literatura, já que o fato da heterogeneidade não ser explicada pela rigidez constitucional não implica que não haja associação real entre emendamento e rigidez, apenas que a rigidez é constante em nossa amostra e consequentemente não pode ser responsável por parte da variabilidade no emendamento estadual.

Além da rigidez constitucional, outra variável fundamental introduzida por Lutz (1994) na literatura de emendamento constitucional é a extensão constitucional. Para o autor, a extensão constitucional reflete a quantidade de questões abordadas na Carta e a partir disso afirma que quanto maior a quantidade de tópicos passíveis de emendamento, maior será a probabilidade de emendamento. A hipótese de que a extensão Constitucional e o tamanho do emendamento são direta e positivamente

\footnotetext{
100 No mecanismo direto quanto maior a rigidez constitucional maiores as barreiras impostas ao emendamento, portanto maior o custo de emendar a constituição e menor o emendamento. Já no mecanismo indireto o emendamento é afetado por conta da adaptação das expectativas, isto é, os agentes, por saberem das elevadas barreiras ao emendamento se adaptam à expectativa de ultrapassar ou não a barreira e reagem com base nela.

101 Já que, independente da metodologia que utilizarmos, as regras são virtualmente iguais no caso do emendamento estadual; portanto, mesmo que exista diferença entre as diversas formas de instrumentalizar o índice de rigidez, estes apresentariam pouca ou nenhuma variação na nossa amostra.
} 
relacionados é uma das mais frequentes na literatura de mudança constitucional, foi amplamente abordada e sistematicamente sustentada (ANCKAR e KARVONEN, 2002; BERKOWITZ e CLAY, 2005; LORENZ, 2005; ELKINS, GINSBURG e MELTON, 2009; NEGRETTO, 2012; GINSBURG e MELTON, 2014; TSEBELIS e NARDI, 2014). Embora $O$ argumento que justifique a relação entre extensão constitucional e intensidade do emendamento apresente certa variação na literatura, seu embasamento teórico é semelhante, se não consensual. Basicamente a extensão constitucional opera como um indicador do grau de especificidade ou detalhamento da Constituição e cartas mais específicas ou detalhadas serão mais frequentemente alteradas.

Sabemos que as constituições estaduais brasileiras não são homogêneas. De fato apresentam certa variabilidade, ainda que não exatamente intensa. Em conformidade com a literatura esperamos que parte da variabilidade no emendamento estadual seja explicada pelo tamanho das próprias constituições promulgadas. Portanto, temos a seguinte hipótese: 
H3: Constituições mais extensas estão associadas com maior emendamento ${ }^{102}$.

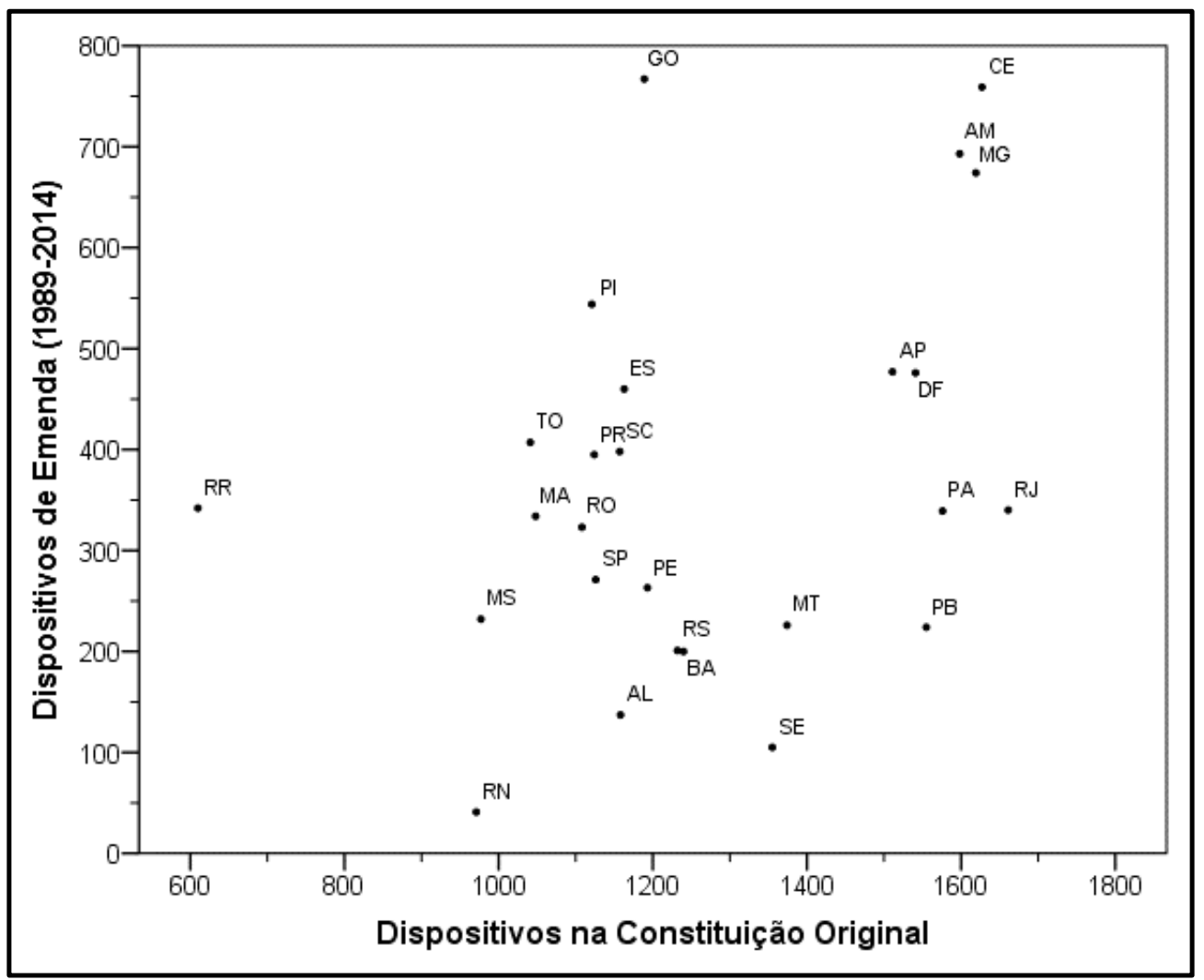

Gráfico 4.2 - Gráfico de Dispersão entre tamanho das Constituições Estaduais e seus Emendamentos

A fim de abordar esta hipótese instrumentalizamos a extensão tanto das constituições quanto do emendamento pela quantidade de dispositivos. Do Gráfico 4.2 vemos que a nuvem de pontos sugere uma associação positiva. Ou seja, há indícios de que constituições mais extensas estão associadas com emendamento mais intenso. No entanto parte desse efeito visual ocorre em virtude da distorção causada por Roraima. Sabemos que a Constituição deste estado, embora não seja formalmente um outlier, é significativamente menor que as demais. Ao ocultar esta observação os indícios se tornam mais sutis na representação gráfica.

Quando formalizada a associação linear vemos que o tamanho do emendamento se mostra fortemente correlacionado com a extensão Constitucional,

\footnotetext{
102 Sabemos que o emendamento é um processo dinâmico, portanto quando uma constituição é emendada sua extensão pode ser alterada em ou não em determinado ponto no tempo. Assim, dentro de nossa hipótese seria esperado que algum tipo de controle anual também fosse inserido, já que a extensão das constituições está em constante alteração em virtude do próprio emendamento. No entanto, em nome da simplificação, optamos por uma abordagem estática.
} 
como era esperado. Em contrapartida não há indícios de associação monotônica ${ }^{103}$ entre as variáveis, ou seja, quando não assumimos a linearidade vemos que não há indícios de que o emendamento varia sistematicamente com a extensão constitucional. Com base nessas informações acreditamos que a existência de associação positiva entre o emendamento e a extensão constitucional não se sustenta ${ }^{104}$, ou se sustenta fracamente. Portanto, não podemos afirmar que a variação na extensão constitucional é suficiente para explicar parte da variação no emendamento estadual. Assim, esta hipótese, extensamente verificada na literatura, não se sustenta no caso das constituições estaduais brasileiras.

Uma diferença significativa de nossa abordagem é a unidade de medida de extensão. Como vimos, a forma mais comum de medir a extensão constitucional é pela contagem de palavras, enquanto que para medir o emendamento utiliza-se a contagem de emendas promulgadas. Ao contabilizar o número de emendas a variável medida não é de fato a alteração constitucional, mas a quantidade de vezes que a barreira institucional da rigidez constitucional foi ultrapassada, e assim emendas que representam grande alteração constitucional são consideradas equivalentes àquelas que praticamente não alteram o texto.

Para Lutz (2006) a extensão de uma constituição - seja ela medida em palavras, sentenças ou seções - é uma medida substituta para o grau de politização de uma Constituição, isto é, o quanto uma Constituição especifica funções tradicionalmente governamentais. Para Ginsburg (2010) a especificidade é um conceito composto por duas dimensões, o escopo e o detalhe. $O$ escopo diz respeito à abrangência de temas tratados na Constituição e o detalhe ${ }^{105}$ indica 0 quão detalhadamente os temas são tratados. De forma semelhante Elkins, Ginsburg e Melton (2009) constroem um índice de detalhamento constitucional a partir da razão

\footnotetext{
${ }^{103}$ Associação monotônica é aquela em que as variáveis apresentam comportamento consistente mas não necessariamente linear. Assim quando uma variável aumenta observamos apenas aumentos ou diminuições na outra variável. Por exemplo, relações lineares, exponenciais ou logarítmicas são monotônicas, ao passo que relações quadráticas não o são.

${ }_{104}$ Com base no mesmo conjunto de dados encontramos relação linear positiva ao mesmo tempo em que não encontramos indícios de relação monotônica. O que indica uma discrepância nos resultados. Sabemos que a extensão das constituições estaduais se distribui de forma bimodal, então, associado com a distorção gerada pelo caso de Roraima, acreditamos que há intensa distorção no coeficiente de correlação resultando em sobrestimação da correlação linear, o que reduz a confiabilidade deste indicador.

105 Uma constituição pouco detalhada regula de forma abstrata os temas, uma muito detalhada deixa pouca margem para interpretação.
} 
entre a quantidade de palavras e o escopo. Os três trabalhos são exemplos de três abordagens diferentes para a mesma questão, a quantidade de funções governamentais, ou políticas públicas, elevadas ao marco constitucional, muito embora cada um deles se utilize de uma forma distinta de medir esse fenômeno.

Quando utilizamos a quantidade de dispositivos como unidade de extensão Constitucional nosso objetivo não é muito diferente. Ao decompor os textos das constituições e emendas em dispositivos podemos também classificar a natureza de cada um desses dispositivos e assim identificar se possuem caráter de política pública (policy) ou de norma propriamente constitucional (polity). Com essa abordagem a identificação da quantidade de políticas públicas, ou o que Lutz (2006) chama de funções governamentais, é direta, e não há necessidade de utilizar uma proxy que capte essa característica, como o detalhamento e o escopo de Elkins, Ginsburg e Melton (2009) e Ginsburg (2010) ou mesmo a quantidade de palavras.

A aplicação da Metodologia de Análise Constitucional (MAC) a fim de classificar cada um dos dispositivos das Constituições estaduais esteve fora do alcance deste trabalho. No entanto, temos indícios de que as Constituições Estaduais replicam, ou pelo menos se baseiam, em grande medida na Constituição Federal. Neste sentido, é razoável assumir que haja alguma proporcionalidade na quantidade de políticas públicas nas Constituições Estaduais e na Constituição Federal, tal como foi analisada por Couto e Arantes (2006). Nossa estratégia foi a de utilizar a proporção de dispositivos de políticas públicas na Constituição Federal para aproximar ${ }^{106}$ a quantidade de dispositivos de políticas públicas nas Constituições estaduais. Dessa forma, e guardadas as limitações dessa estratégia, podemos testar um desdobramento da hipótese de extensão constitucional:

H4: Constituições com maior quantidade de políticas públicas apresentam emendamento mais elevado.

\footnotetext{
106 Mesmo que haja semelhança nos textos a Metodologia de Análise Constitucional se utiliza de diversos critérios a fim de identificar uma política pública constitucionalizada, portanto não esperamos que a mera transposição das proporções seja uma medida suficiente para determinar a quantidade de políticas públicas nas Constituições estaduais, mas é a melhor aproximação que conseguimos.
} 
Do Gráfico 4.3 encontramos indícios de associação entre a quantidade estimada de policies nas Constituições Estaduais e o emendamento constitucional nos estados. Quando a formalizamos encontramos evidências estatísticas para sustentar

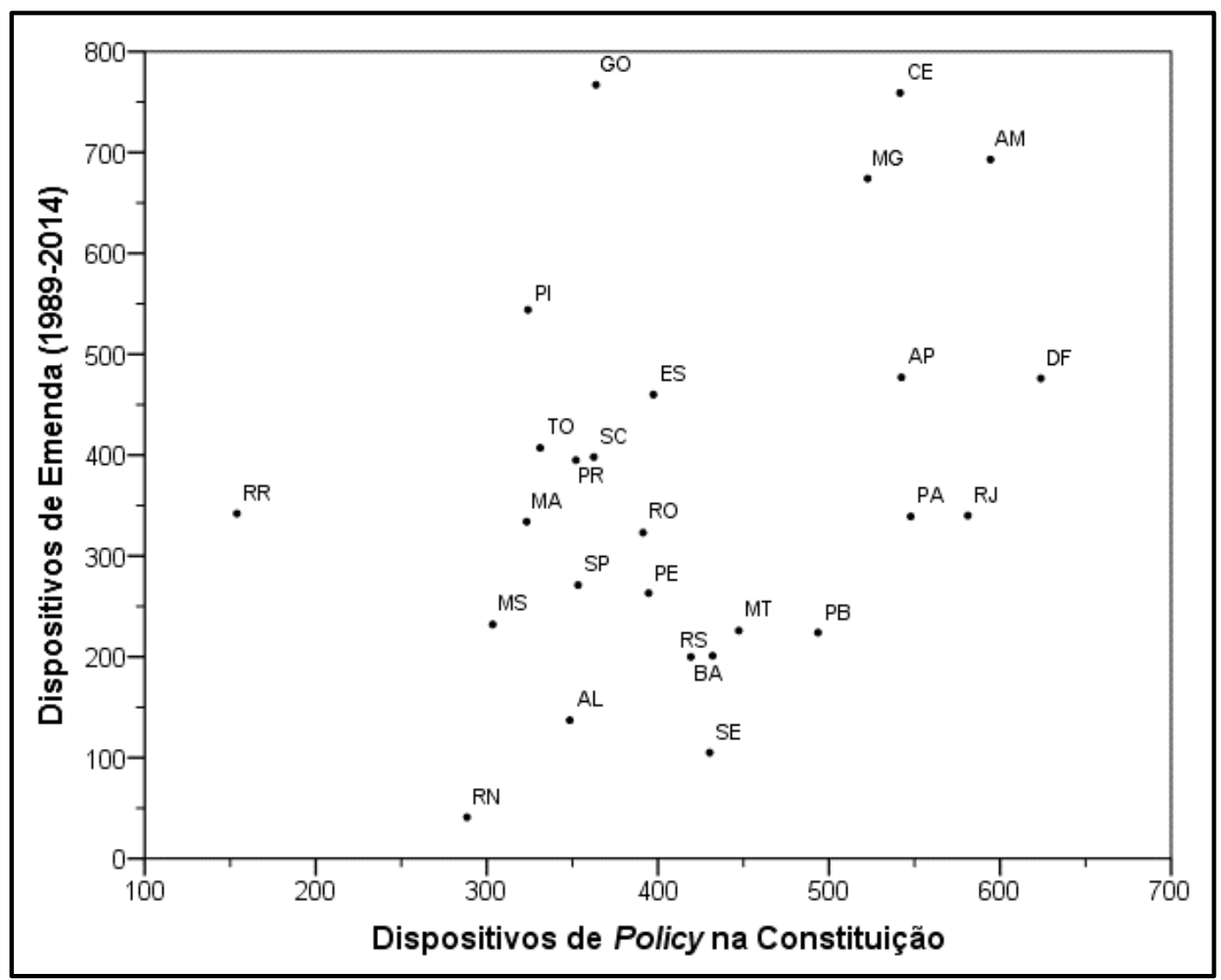

Gráfico 4.3 - Gráfico de Dispersão entre o Emendamento e o total de Policies Constitucionalizadas

a existência dessa relação, seja em termos lineares ou monotônicos. No entanto, devemos fazer duas ressalvas. A primeira é que o estado de Roraima, embora não seja formalmente um outlier, causa certa distorção tanto no gráfico quanto nos dados; a segunda é que os dispositivos constitucionais pertencentes ao ADCT não foram inseridos na análise, já que não foram classificados por Couto e Arantes (2006) no espectro policy e polity. Apesar dessas ressalvas, acreditamos que encontramos evidências suficientes para sustentar que parte da variabilidade no emendamento estadual advém da quantidade de políticas públicas elevadas ao marco constitucional na ocasião da promulgação de suas Constituições.

Por fim, como última hipótese institucional, abordamos a relação entre o emendamento federal e o emendamento estadual. Quando comparamos o emendamento estadual e o emendamento federal ao ano identificamos semelhança 
marcante e o que nos pareceu algum tipo de eco no emendamento. No Gráfico 3.4 (p.90) observamos que um ano após picos ou vales no emendamento federal o emendamento estadual apresenta comportamento semelhante. Isso sugere que parte do emendamento estadual é explicado pelo próprio emendamento federal.

H5: Emendamentos federais em um ano ensejam emendamento estadual nos anos seguintes.

Já abordamos parcialmente essa hipótese de forma qualitativa e encontramos indícios de que os estados emendam temas semelhantes aos temas emendados pela União no ano anterior. A fim de abordar, simplificadamente, a hipótese de uma forma quantitativa comparamos então o emendamento federal com o emendamento estadual defasado em um ano. No Gráfico 4.4 cada ponto indica o total de dispositivos de emenda promulgados pelos estados em um ano e o total de dispositivos de emenda promulgados pela União no ano anterior.

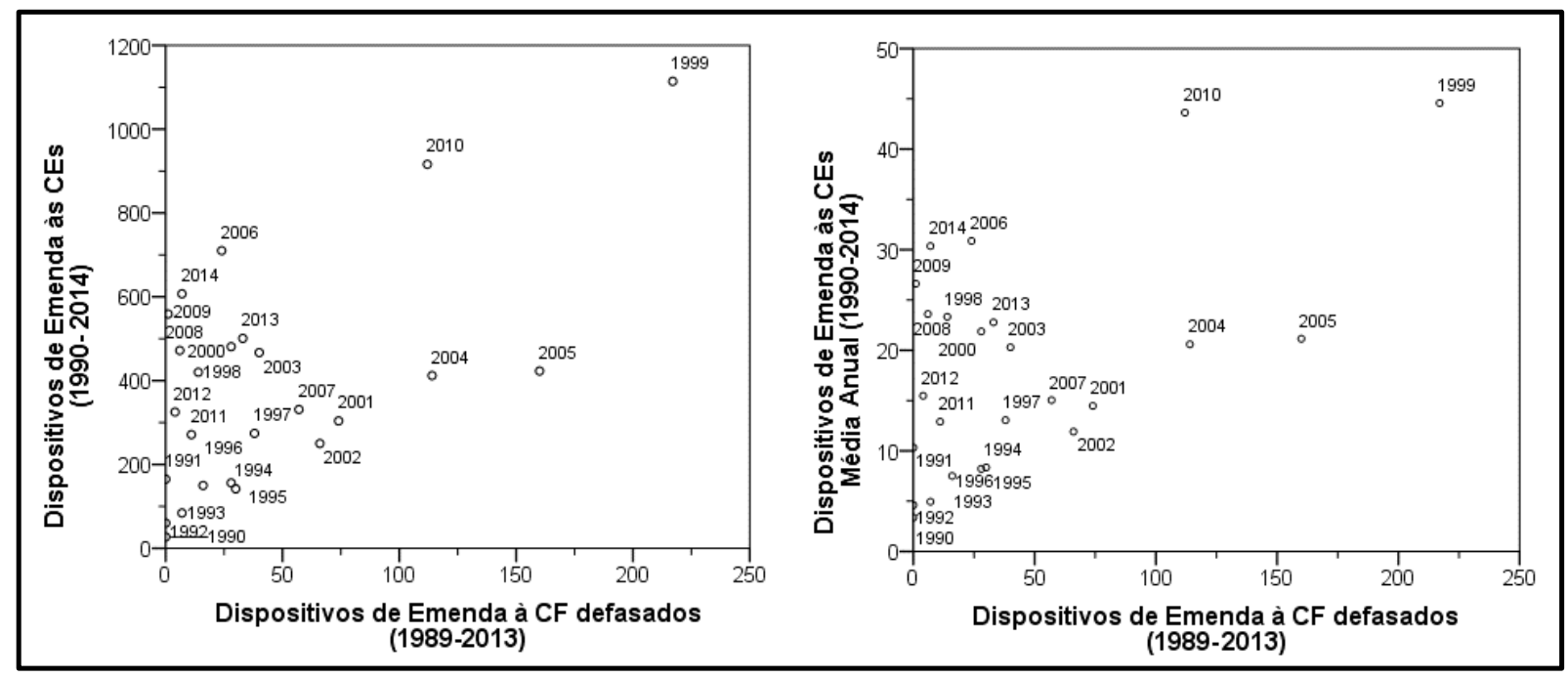

Gráfico 4.4 - Gráficos de Dispersão entre o Emendamento anual nos Estados e União

No Gráfico 4.4 há indícios de que o emendamento estadual de certa forma é diretamente influenciado pelo emendamento federal do ano anterior. Ao formalizar a associação encontramos evidências satisfatórias de relação linear forte e associação monotônica intermediária. Mesmo que a associação linear seja superestimada acreditamos que há evidências quantitativas suficientes para sustentar que o emendamento estadual apresenta um eco de um ano com relação ao emendamento Federal. Essa hipótese sugere então que o emendamento nos estados brasileiros é em grande parte influenciado pelo próprio emendamento da Constituição Federal. 
No entanto essa hipótese não fornece maiores informações acerca da variabilidade no emendamento entre os estados. Para esta abordagem consideramos o total de dispositivos de emenda às Constituições Estaduais promulgados por todos os estados em cada ano. Portanto é o emendamento estadual como um todo que apresenta este eco. Como não há discriminação por estado, não podemos afirmar que a intensidade do emendamento varia entre os estados por consequência do emendamento federal, mas sim que o emendamento estadual parece sofrer influência significativa dos emendamentos federais anteriores.

\subsection{Hipóteses Políticas}

Neste último conjunto de hipóteses abordamos o emendamento sob uma perspectiva política. Exploramos a associação do emendamento com o jogo político estadual em especial os resultados eleitorais. Essa conjunto de hipóteses advém de uma tentativa de relacionar o emendamento constitucional para além do arranjo institucional, mas sob as regras por ele estabelecido.

As regras de proposição e aprovação de emendas constitucionais são virtualmente iguais entre os estados. No entanto mesmo sob regras equivalentes o poder de proposição e aprovação de emendas dos diferentes atores pode variar como consequência do resultado do jogo político. Em todos os estados os governadores ou um consenso mínimo de um terço de deputados detém capacidade de proposição de emendas. Já para a aprovação o requisito é de uma maioria qualificada nas assembleias, em dois turnos, enquanto os governadores não participam desta etapa.

Então mesmo que todos os governadores tenham a mesma capacidade institucional de proposição de emendas, esperamos que haja alguma relação entre a força política detida pelo governador e o emendamento. No entanto não observamos as emendas propostas, mas sim as aprovadas ${ }^{107}$. Nossa primeira hipótese deste conjunto é:

107 Além de não observamos as emendas propostas e recusadas ou ainda não votadas, também não observamos aquelas que não foram formalizadas por conta de negociações anteriores. Assim nosso 
H6: A força política dos governadores está associada com o emendamento constitucional.

Por um lado podemos argumentar que governadores mais fortes afetam de forma positiva o emendamento, já que conforma mais politicamente influentes terão maior capacidade de fazer com que emendas de sua autoria sejam aprovadas, e com isso cristalizar suas preferências, seja pela constitucionalização de matérias de seu interesse ou alteração de decisões passadas também constitucionalizadas. Assim governadores mais fortes estariam associados a emendamento mais intenso. Por outro lado também podemos argumentar que governadores mais fortes não têm necessidade de estabelecer ou fixar controle por meio da constitucionalização de matérias em virtude dessa própria força. Isto é, como exercem influência política significativa sobre a assembleia não há necessidade de cristalizar suas preferências.

Para instrumentalizar a força dos governadores utilizamos três variáveis distintas. A porcentagem de votos obtida pelos governadores na eleição, se foram eleitos em primeiro ou segundo turno ${ }^{108}$ e finalmente utilizamos como medida do tamanho da coalizão governista na assembleia a proporção de deputados estaduais eleitos pelos partidos que compõe a coligação do governador eleito. Esta porcentagem mede apenas a porcentagem de cadeiras da coligação no momento da eleição, e portanto não é uma medida adequada de coalizão nas assembleias, no entanto nossa tentativa de construir um índice foi infrutífera e não encontramos substituto adequado.

A fim de medir a coalizão governista na assembleia legislativa nossa primeira abordagem foi desenvolver um questionário a ser respondido por funcionários das assembleias legislativas. No questionário identificamos os resultados eleitorais das eleições estaduais para governador e assembleias legislativas de cada eleição entre 1990 e 2010 para todos os estados bem como a composição partidária anual de cada legislatura, não em termos de proporção de cadeiras, mas simplesmente os partidos que detinham pelo menos um representante eleito. Com isso nosso objetivo era que

foco se concentra apenas sobre aquelas emendas que foram aprovadas, o que pode gerar considerável viés para a análise, a opção por observar apenas as emendas aprovadas se deu em virtude da falta de disponibilidade dos dados.

108 No caso dos governadores eleitos em segundo turno consideramos a porcentagem de votos no segundo turno, e não no primeiro. 
integrantes das assembleias legislativas identificassem aqueles partidos que de forma geral votaram ou apoiaram o governador em cada ano das legislaturas e assim, com base na quantidade de deputados eleitos por estes partidos, construir um indicador da coalizão governista. Todavia a abordagem foi infrutífera, seja porque não recebemos respostas das assembleias, porque não conseguimos estabelecer alguma forma de contato ou porque de acordo com funcionários as informações acerca das votações não eram armazenadas.

Se há alguma associação entre a força dos governadores e o emendamento constitucional esperamos que apresente retornos decrescentes, de forma que a variação no emendamento será cada vez mais reduzida quanto mais forte o governador. Para captar esse efeito decrescente utilizamos uma transformação logarítmica na quantidade de dispositivos. Ou seja, esperamos que uma variação de $20 \%$ para $30 \%$ na proporção de cadeiras da coligação governista seja observada com uma variação mais intensa no emendamento do que quando há variação de $80 \%$ para $90 \%$ nesta proporção.

Do Gráfico 4.5 não parece existir relação observável entre a força dos governadores e o emendamento, independente da forma que medimos a força dos governadores. Assim não parece haver padrão de associação entre as variáveis. Quando formalizamos a associação por meio das correlações também não é possível observar associação linear ou monotônica ${ }^{109}$, mesmo quando controlamos para 0 turno no qual o governador foi eleito. Embora esteja fora de nosso escopo podemos destacar que, nos gráficos, parece haver relação entre o turno de eleição e a

109 Independente de utilizarmos a transformação logarítmica ou não, não é possível identificar associação. 
proporção de cadeiras da coligação governista, já que nenhum caso governadores eleitos em segundo turno são observados com mais de $60 \%$ das cadeiras.

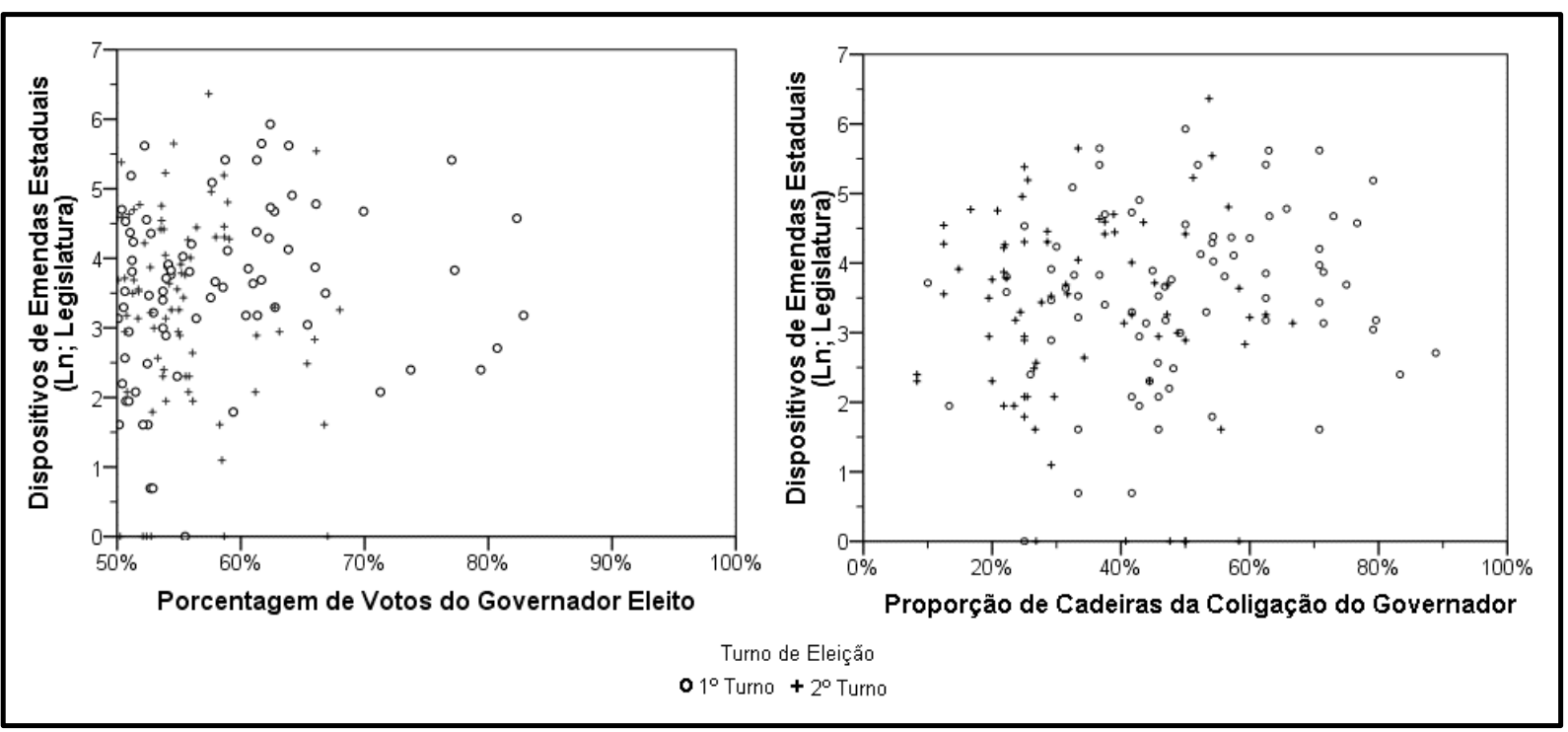

Gráfico 4.5 - Gráficos de Dispersão da Força do Governador

Para Negretto (2012) além da rigidez constitucional, ou das regras de aprovação de emendas, a fragmentação do sistema partidário é fundamental para explicar o emendamento. Segundo o autor é a interação entre essas duas variáveis que deve explicar parte da alteração constitucional, em que menor emendamento é esperado quanto mais rígidas forem as regras de alteração constitucional e mais fragmentado for o sistema partidário. No entanto em seus resultados o autor encontra que a fragmentação partidária causa maior emendamento quando a rigidez constitucional é baixa mas é inconclusivo quando tanto a rigidez quando a fragmentação são elevadas. No caso brasileiro a rigidez constitucional é constante entre os estados, então esperamos que maior fragmentação partidária e menor emendamento sejam observados em conjunto. Já que com maior quantidade de partidos e cada um deles menos representado, o custo para a formação de maiorias qualificadas é mais elevado, o que torna a aprovação de emendas mais difícil.

H7:Maior fragmentação partidária será observada em conjunto com menor emendamento.

A fim de captar a fragmentação partidária utilizamos o Número Efetivo de Partidos (NEP) de Laakso e Taagepera (1979) calculado para cada legislatura. Além do NEP construímos também um índice efetivo de coligações, baseado no mesmo 
método de cálculo mas que considera não a porcentagem de cadeiras eleita por cada partido nas assembleias, mas sim a porcentagem de cadeiras eleitas por cada coligação eleitoral ${ }^{110}$. Assim esperamos que este segundo índice capte melhor as alianças e interações entre partidos.
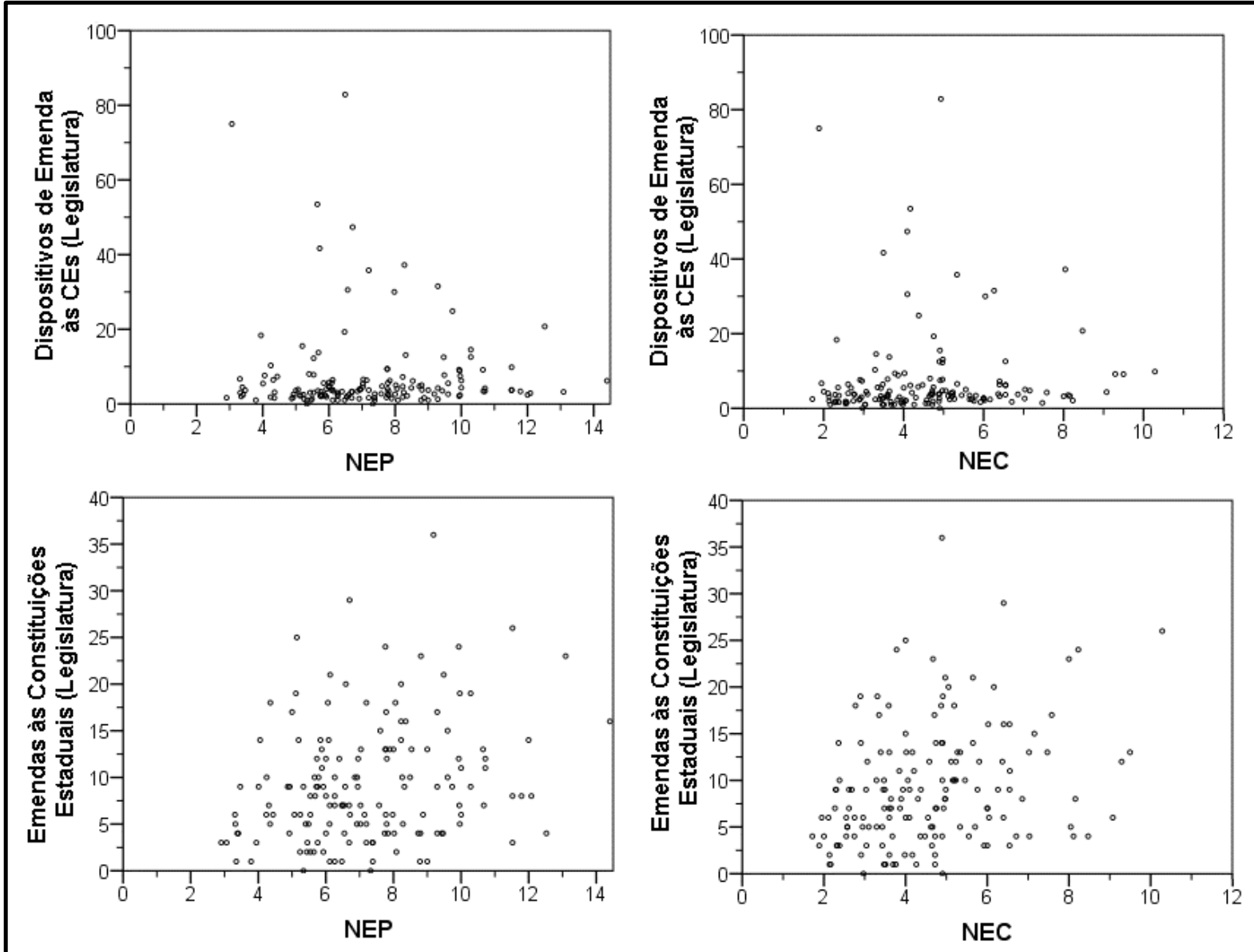

Gráfico 4.6 - Gráficos de Dispersão entre Emendamento e Fragmentação Política

Em um primeiro momento não encontramos indícios de associação entre 0 emendamento e a fragmentação, seja esta medida em número efetivo de partidos ou de coligações. No entanto, do Gráfico 4.6 vemos que a quantidade de dispositivos de emenda promulgados por legislatura é assimétrica. Do total de 154 legislaturas estaduais observadas, em 100 há promulgação de 50 ou menos dispositivos - para um total de 2.204 dispositivos - enquanto que nas demais 54 legislaturas observamos o total 7.390 dispositivos, o que distorce os gráficos e dificulta a visualização de possível relação. Quando formalizamos a relação encontramos uma associação linear

${ }^{110}$ Aqui assumimos que um partido não coligado que elege deputados é considerado uma coligação de apenas um partido, portanto a ideia do índice é captar diferentes alianças no momento eleitoral e com isso substituir, de forma simplificada, medidas de coalizão partidária dentro das assembleias legislativas. 
fraca entre o NEC e a quantidade de dispositivos promulgados por legislatura e associação monotônica moderada entre o emendamento e a fragmentação política, seja esta medida em número efetivo de partidos ou de coligações.

Assim o resultado que encontramos é contrário a nossas expectativas. Nosso argumento, alinhado com o de Negretto (2012) apontaria para uma relação negativa, em que sistemas políticos mais fragmentados estariam associados com menor emendamento, especialmente sob regras iguais. Mas há uma diferença significativa em nossas abordagens, a forma de medir o emendamento constitucional. A associação positiva entre emendamento e fragmentação política pode advir não do fato de que sistemas políticos mais fragmentados emendam mais, mas sim que em sistemas políticos mais fragmentados os emendamentos são maiores.

Uma explicação, ad hoc, é que em virtude da maior fragmentação política uma maior quantidade de interesses deve ser contemplada, portanto por conta de um possível sistema de log-rolling os partidos compensariam custos mais elevados do emendamento em assembleias fragmentadas - assumindo que esses custos existem - pela inserção de seus interesses particularistas, o que resulta em emendamento mais extenso. 


\section{Considerações finais}

Ao abordar o constitucionalismo estadual nosso objetivo não foi desenvolver modelos explicativos extensos a fim de determinar as causas do emendamento constitucional, mas sim desenvolver uma análise exploratória capaz de abordar de forma simplificada perguntas importantes na literatura sobre o tema bem como explorar um fenômeno ainda pouco estudado, especialmente no Brasil. Buscamos atingir este objetivo pela descrição das Constituições e do Emendamento nos estados brasileiros assim como pelo teste de algumas hipóteses.

Da análise descritiva das Constituições Estaduais vemos que estas, quando promulgadas, apresentaram certa variabilidade na extensão dos textos. No entanto encontramos variabilidade apenas em termos absolutos, isto é, no tamanho das Constituições medidas em quantidade de dispositivos. Quando consideramos os temas abordados, todavia, vemos que há uma estrutura semelhante entre elas. Mesmo que as Constituições estaduais apresentem quantidade distinta de dispositivos, quando agrupamos os dispositivos por um sistema temático padronizado vemos que, em termos proporcionais, as Constituições estaduais são semelhantes. Semelhança essa que também é encontrada em relação à Constituição Federal, da qual partiu nossa padronização de agrupamentos temáticos.

Essa semelhança temática entre as Cartas corrobora a ideia de que há uma semelhança textual significativa, possivelmente decorrente do princípio da simetria. Ao observar o próprio texto Constitucional também vemos que há trechos inteiros com semelhanças que chegam à cópia ipsis literis. Com isso as Constituições Estaduais promulgadas após 1989 apresentam extensão variada ao mesmo tempo que possuem estruturas semelhantes e trechos inteiros copiados da Constituição Federal.

Da descrição do emendamento vemos que também há certa variabilidade. Mas também encontramos uma estrutura temática semelhante entre os estados. Portanto, mesmo que os estados emendem em intensidades distintas, seus emendamentos se distribuem de forma proporcionalmente semelhante. Vale notar que assim como na extensão Constitucional, o emendamento estadual é significativamente inferior ao emendamento Federal. Pelo impacto final do 
emendamento vemos que a Constituição Federal cresce - quanto contabilizamos como crescimento líquido os aglutinadores menos os revogados - que as Constituições Estaduais. No entanto a utilização de dispositivos aglutinadores é mais comum no cenário estadual. Então por mais que no resultado final as Constituições Estaduais cresçam menos do que a Constituição Federal, é mais frequente que aquelas se utilizem de nova adições aos seus textos do que modificações. E entre 1989 e 2014 a utilização de dispositivos aglutinadores se tornou mais comum, portanto os legisladores estaduais vem optando cada vez mais pela inserção de novos dispositivos. Outra distinção significativa é que no emendamento estadual o fenômeno de emendamento sobre emendamento é mais comum que no cenário federal, com alguns casos de até cinco sobreposições.

Duas características que se destacam no emendamento estadual são a autoria das emendas e a frequência anual. Ao levantar a autoria das emendas constitucionais estaduais, e portanto dos dispositivos, identificamos uma situação contrária à observada no cenário federal. Enquanto na União o poder Executivo é responsável pela proposição de aproximadamente $50 \%$ do emendamento, nos estados o legislativo é significativamente predominante, já que uma média de $75 \%$ são de autoria deste. Assim, no cenário estadual o principal ator responsável pela proposição das emendas Constitucionais - que foram aprovadas - são as Assembleias Legislativas. Embora nosso estudo não tenha avançado qualquer hipótese explicativa sobre este resultado, uma plausível seria a de que assembleias recorrem com frequência a emendas constitucionais porque estas não são submetidas a sanção pelo governador estadual (e, portanto, não estão sujeitas a veto do executivo). Este fenômeno daria causa a outro, que é o uso frequente que os governadores fazem da Ação Direta de Inconstitucionalidade perante o STF, contra legislação produzida por suas respectivas assembleias, incluindo aí as emendas constitucionais.

Nesse sentido, o cenário com o qual nos deparamos é o de Constituições Estaduais promulgadas virtualmente na mesma data, com tamanhos distintos mas estrutura temática muito semelhante, além de indícios de uma equivalência significativa com o texto da Constituição Federal. Constituições estas que no período entre sua promulgação e o ano de 2014 apresentaram emendamento variado, mas também sob uma estrutura temática equivalente. Esta variabilidade de emendamento 
se dá sob um arranjo institucional no qual a rigidez constitucional é homogênea entre os estados, em função da diferença insignificante nas regras de aprovação de emendas e da não utilização dos diversos mecanismos peculiares de proposição encontrados. Dentro deste cenário buscamos fatores que podem se associar com o emendamento constitucional a fim de explicar parte de sua variabilidade.

Quando consideramos as hipóteses levantadas vemos que no caso das Constituições estaduais brasileiras o contexto econômico não parece estar associado com o emendamento, e também não há indícios de que a extensão constitucional se relaciona com o emendamento. No entanto, ao medir extensão constitucional nosso objetivo foi também o de captar o possível impacto de políticas públicas inseridas nos textos constitucionais. Assim, quando comparamos o emendamento com a frequência de políticas públicas encontramos que há uma associação entre as variáveis, então parte da variabilidade no emendamento constitucional pode ser explicado pela presença de políticas públicas, de forma que quanto mais políticas públicas constitucionalizadas maior será o emendamento encontrado nos estados.

Também encontramos indícios de que o emendamento estadual apresenta alguma relação intertemporal com o emendamento federal. Em uma abordagem qualitativa identificamos uma série de emendas às constituições estaduais cuja ementa indica expressamente que o objetivo daquela é adequar a Constituição Estadual às alterações sofridas pela Constituição Federal, enquanto que em outros casos identificamos que amplas reformas na Constituição Federal, como a reforma do Judiciário, ensejaram emendamento semelhante por parte dos estados nos anos seguintes. Sob uma perspectiva quantitativa defasamos o emendamento estadual em um ano e o comparamos com o emendamento federal, de forma que pareamos 0 emendamento Constitucional Estadual em um ano com o Emendamento Federal no ano anterior. Pela abordagem quantitativa também encontramos indícios de que o emendamento estadual parece reproduzir em partes o emendamento federal.

Deste modo, não só as Constituições Estaduais foram promulgadas com texto e estrutura semelhantes à Constituição Federal, mas seu emendamento entre $1989 \mathrm{e}$ 2014 também apresenta proximidade marcante com o emendamento Federal. 
Além do cenário institucional avaliamos também consequências políticas. Vemos que não há indícios de que os governadores exercem influência significativa no processo de emendamento. Isto é, independente do governador ser identificado com base eleitoral forte ou mesmo com força na assembleia, o emendamento não parece ser afetado de forma sistemática por este tipo de força. Da análise descritiva do emendamento constitucional identificamos que uma parcela reduzida das emendas é de autoria dos governadores, o que corrobora a reduzida participação do executivo no processo de emendamento estadual.

Neste cenário de predominância do legislativo, identificamos também uma associação do emendamento Constitucional com a fragmentação político-partidária nas assembleias. Quanto maior a fragmentação partidária, medida pelo NEP, maior será o número de emendas aprovadas e maior a quantidade de dispositivos aprovados, cujo efeito final é maior média de dispositivos por emenda. Assim, legislaturas mais fragmentadas tendem a apresentar maior número de emendas aprovadas, sendo estas também de extensão maior. Mas este índice de fragmentação não reflete efetivamente a dimensão do processo legislativo dentro das assembleias, especialmente para o caso da alteração constitucional, já que são necessárias maiorias qualificadas para que uma emenda seja aprovada e os partidos devem se aliar e montar coalizões a fim de aprovar ou rejeitar as propostas. Assim utilizamos uma variação do NEP que visa captar a fragmentação das alianças dentro das assembleias, o que chamamos de Número Efetivo de Coligações. Quando utilizamos este índice identificamos um efeito mais intenso, isto é, assembleias formadas por um maior número de coligações, tendem a produzir maior emendamento da mesma que a maior fragmentação partidária, no entanto os efeitos são mais intensos.

Assim, concluímos essa dissertação destacando três possíveis fatores que se associam com o emendamento estadual. Quanto maior a quantidade de políticas públicas presentes na Constituição maior será o emendamento, quanto maior for o emendamento à Constituição Federal maior será o emendamento, no ano seguinte, às Constituições Estaduais e, por fim, quanto maior a fragmentação político-partidária maior o emendamento como um todo. Nosso primeiro achado é que a constitucionalização de políticas públicas é um fenômeno que se espraiou também pelas constituições estaduais e tem produzido efeito sobre a dinâmica política local, 
levando a um processo legislativo que inclui o emendamento como uma de suas principais atividades.

Dado o caráter especial do emendamento e as exigências de quórum elevado para sua aprovação, outro achado importante é que a fragmentação partidária importa. Poucos estudos sobre emendamento constitucional conseguiram mobilizar essa variável interveniente do sistema político para analisar o impacto que as regras de mudança constitucional causam efetivamente sobre o processo de alteração das constituições. As regras que definem o grau de rigidez de uma constituição não definem o perfil do sistema partidário e este tem impacto sobre aquela. Quando não incorporado devidamente pela análise, é como se a regra de emendamento operasse no vazio, mas não é isso que ocorre nas democracias. Dessa forma, diferentes configurações partidárias farão a regra causar efeitos distintos. O que nosso estudo demonstrou é que a configuração do sistema partidário das assembleias legislativas importa e faz variar o emendamento numa direção específica e por demais interessante: quanto maior a fragmentação, maior o tamanho das emendas aprovadas, sugerindo que a necessidade de envolver um número maior de forças políticas para romper o patamar da aprovação está levando a modificações constitucionais de maior extensão, com impacto atual e futuro sobre o texto principal e sobre o próprio jogo político.

O terceiro achado nos faz refletir sobre o desenho federativo que adotamos em 1988 e a larga influência que a constituição federal vem exercendo sobre a interação entre os poderes mas também entre os níveis de governo (federal, estadual e municipal). Os inúmeros estudos disponíveis nos dão conta dessa influência, inclusive no que diz respeito à constitucionalização de políticas públicas. O que nosso estudo acrescenta a essa discussão é a confirmação da similaridade dos textos estaduais para com o federal e o impacto deste, quando é alterado, sobre o conjunto das constituições estaduais. Em outras palavras, vale destacar que o país é governado por $27+1$ constituições e elas conformam num sistema constitucional com múltiplas interações, envolvendo regras e atores num jogo político cujas linhas principais pode agora ser um pouco melhor compreendido.

Dessa forma, esperamos ter contribuído para o conhecimento de dimensões pouco estudadas de nosso sistema político, situadas no plano estadual, embora 
nossas conclusões possam não ter abarcado toda a complexidade do fenômeno da política constitucional dos estados brasileiros, ensejando assim a necessidade de novas investigações sobre o tema. 


\section{Referências Bibliográficas}

ABRÚCIO, Fernando (1998). "Os Barões da Federação". São Paulo, Hucitec/DCP-USP.

ANCKAR, Dag \& KARVONEN, Lauri (2002). "Constitutional Amendment Methods in the Democracies of the World". Paper presented at the XIII Nordic Political Science Congress, Aalborg.Denmark, 15-17 de Agosto.

ARANTES, Rogério B. e COUTO, Cláudio G (2009) "Uma constituição incomum". In: Carvalho, M. A. R.; Araújo, C; Simoes, J. A. (Org.). A constituição de 1988. Passado e Futuro. São Paulo: Aderaldo \& Rothschild: Anpocs, 2009, p. 17-51.

(2010). "Construção Democrática e Modelos de Constituição". Revista Dados, Rio de Janeiro, v.53, p. 545-585

(2012) "Constitutionalizing Policy: The Brazilian Constitution of 1988 and its Impact on Governance". In Nolte, Detlef e Schilling-Vacaflor, Almut."New Constitutionalism in Latin America from a Comparative Perspective: A step towards good governance?" Ashgate, 2012.

ARRETCHE, Marta .(2001). "Federalismo e democracia no Brasil: a visão da ciência política norteamericana". São Paulo em Perspectiva. Fundação SEADE, v. 15, n. 4, p. 23-31, 2001.

(2013a) "Quando instituições federativas fortalecem o governo central?" Novos Estudos/Cebrap, v. 95, 2013, p. 38-57.

(2013b). "Demos-Constraining or Demos-enabling Federalism? Political Institutions and Policy Change in Brasil”. In: Journal of Politics in Latin America (internet), v.5, p.133-150.

BECHARA, Evanildo. (2009) "Moderna Gramática Portuguesa". 36 ed., SP: Companhia Editora Nacional, 1997.

BERKOWITZ, Daniel e CLAY. Karen. (2005). "American Civil Law Origins: Implications for State Constitutions" American Law and Economics Review, Oxford University Press, vol. 7, pages 62-84.

BJØRNSKOV, Christian; VOIGT, Stefan. (2013) "Constitutional verbosity and social trust". Public Choice v. 161, n. 1-2, p. 91-112, 2013. Disponível em: <http://link.springer.com/10.1007/s11127-0130129-z>.

BRASIL. Lei Complementar ํo 95, de 27 de Fevereiro de 1998. "Dispõe sobre a elaboração, a redação, a alteração e a consolidação das leis, conforme determina o parágrafo único do art. 59 da constituição federal, e estabelece normas para a consolidação dos atos normativos que menciona." Diário Oficial de 27/02/1998, P. 1. Disponível em: <https://www.planalto.gov.br/ccivil_03/leis/lcp/lcp95.htm>

BRASIL. Supremo Tribunal Federal. Precatório. Recurso Extraordinário no 160.486. Relator: Ministro Celso de Mello. Julgado em 11 de outubro de 1994, Primeira Turma, DJ de 9 de Junho de 1995.

BRASIL. Senado Federal. Consultoria Legislativa. "Manual de elaboração de textos" Brasília : Senado Federal, Consultoria Legislativa, 1999. 88p.

BRASIL. Presidência da República. "Manual de Redação da Presidência da República". 2.ed. rev. e atual., Brasília : Presidência da República, 2002. 140 p.

BRASIL. Congresso. Câmara dos Deputados. "Manual de redação da Câmara dos Deputados". Brasília: Câmara dos Deputados, Coordenação de Publicações, 2004. 420 p. Série fontes de referência. Guias e manuais. n. 17 
BRASIL. Constituição (1988). Constituição da República Federativa do Brasil. Brasília, DF: Senado Federal.

CAPEZ, Fernando; (2003) "Direito Constitucional". São Paulo: Damásio de Jesus. 2003

CEARÁ, Constituição. (1989). Emenda Constitucional n. 20, de 23 de Dezembro de 1995. "Altera dispositivos da constituição do estado do ceará. (arts. 84, 86 e 87)" Fortaleza, 1995.

CEARÁ, Constituição. (1989). Emenda Constitucional n. 27, de 29 de Março de 1994. "Acrescenta parágrafo ao art. 87 , da constituição estadual, renumerando o parágrafo único, que passa a ser o §1"”. Fortaleza, 1996.

CEARÁ, Constituição. (1989). Emenda Constitucional n. 50, de 16 de Dezembro de 2002. "Acrescenta § 2 ao art. 87 da constituição do estado." Fortaleza, 1995.

CEARÁ, Constituição. (1989). Emenda Constitucional n. 59, de 26 de Dezembro de 2006. "Revoga o $\S 2^{\circ}$ do art. 87 da constituição do estado do ceará, acrescido pela emenda constitucional $n=50$, de 16 de dezembro de 2002, e dá outras providências." Fortaleza, 2006.

COSTA, Valeriano (2007). "Federalismo". In: AVELAR, Lúcia \& CINTRA, Antônio Octávio. Sistema Político Brasileiro: uma introdução. Unesp, 2007, p. 211-224.

COUTO, Cláudio Gonçalves (2005). "Constituição, competição e políticas públicas". Lua Nova, São Paulo, n. 65, p. 95-135, 2005.

COUTO, Cláudio Gonçalves e ARANTES, Rogério Bastos. (2002), "Constituição ou políticas públicas? Uma avaliação dos anos FHC". In: loureiro, Maria Rita \& abrucio, Fernando Luiz (orgs.). 0 Estado numa era de reformas: os anos FHC, Brasília, Enap.

COUTO, Cláudio G. \& ARANTES, Rogério B (2006). "Constituição, governo e democracia no Brasil". Revista Brasileira de Ciências Sociais, São Paulo, v. 21, n. 61, 2006

CRAMER, Duncan e HOWITT, D. (2004). "The SAGE Dictionary of Statistics". London, England: SAGE Publications, Disponível em: http://dx.doi.org/10.4135/9780857020123

DOANE, David P e SEWARD, Lori E; (2011) "Measuring Skewness: A Forgotten Statistic?" Journal of Statistics Education, v. 19, n. 2, 2011

ELKINS, Zachary, GINSBURG, Tom \& MELTON, James. (2009). "The Endurance of National Constitutions". Cambridge University Press.

FIGUEIREDO, Argelina e LIMONGI, Fernando (1998). "Bases institucionais do presidencialismo de coalizão". Lua Nova 38: pp.81-106, 1998, disponível em http://www.scielo.br/pdf/ln/n44/a05n44.pdf.

FREEDMAN, D. e DIACONS, P; (1981) "On the histogram as a density estimator" Zeitschrift fur Wahrscheinlichkeitstheorie und verwandte Gebiete n 57, p. 453-476.

GINSBURG, Tom (2010). "Constitutional Specificity, Unwritten Understandings and Constitutional Agreement" 11 de Novembro de 2010. University of Chicago, Public Law Working Paper No. 330

GINSBURG, Tom; MELTON, James. (2014) "Does the Constitutional Amendment Rate Rule Matter at All? Amendment Cultures and the Challenges of Measuring Amendment Difficulty". 2014. Disponível em: <http://papers.ssrn.com/sol3/papers.cfm?abstract_id=2142163>.3127020864.

GIOVANNONI, Francesco. (2003). "Amendment Rules in Constitutions". Public Choice n. 115. Springer: 37-61. Disponível em: http://www.jstor.org/stable/30025973.

GOIÁS, Constituição. (1989). Emenda Constitucional n. 11, de 09 de Setembro de 2010. Altera a Constituição Estadual atualizando-a em conformidade com a Constituição da República. Goiânia, 2010. 
HAMMONS, Christopher W.(1999) "Was James Madison Wrong? Rethinking the American Preference for Short, Framework-Oriented Constitutions" The American Political Science Review v. 93 , n. 4 , p. 837-849, 1999.0003-0554.

HYNDMAN, R J (1995). "The problem with Sturges' rule for constructing histograms". Monash University n. July, p. 1-2, 1995.

KINCAID, J. (1988) "State Constitutions in the Federal System". The ANNALS of the American Academy of Political and Social Science v. 496, n. 1, p. 12-22, 1988.00027162.

LAAKSO, Markku; TAAGEPERA, Rein. (1979) "The "Effective" Number of Parties: A Measure with Application to West Europe." Comparative Political Studies v. 12, p. 3-27, 1979.0010-4140.

LIJPHART, Arend. (1999) "Patterns of Democracy: Government Forms and Performance in ThirtySix Countries.", 1999. p. 351.

LORENZ, Astrid. (2005) "How to Measure Constitutional Rigidity: Four Concepts and Two Alternatives". Journal of Theoretical Politics v. 17, n. 3, p. 339-361 , 2005.0951-6298.

LORENZ, Astrid. (2012) "Explaining Constitutional Change: Comparing the Logic, Advantages and Shortcomings of Static and Dynamic Approaches". p. 31-50, 2012.

LUTZ, Donald S. (1994) "Towards a theory of constitutional amendment". American Political Science Review v. 88, n. 2, p. 355-370, 1994.0003-0554.

LUTZ, Donald S.(2006) "Principles of Constitutional Design".Cambridge University Press, 2006. .

MEZEY, Michael L. (1983). "The Functions of Legislatures in the Third World." Legislative Studies Quarterly 8, no. 4.

MINAS GERAIS. "Manual de redação parlamentar". 3. ed. Belo Horizonte: Assembleia Legislativa do Estado de Minas Gerais, 2013. 396 p.

MONTENEGRO, Alvaro A. "1995". "Constitutional Design and Economic Performance", Constitutional Political Economy n. 6:p.161-9

MOTTA, Sylvio; DOUGLAS; William. (2002) "Controle de Constitucionalidade". Rio de Janeiro: Impetus. 2002.

NEGRETTO, Gabriel L. (2012). "Replacing and Amending Constitutions: The Logic of Constitutional Change in Latin America". Law and Society Review n. 46 p:749-79.

NORONHA, Lincoln N T. (2014) "Em Direção a uma Teoria de Emendamento Constitucional: Críticas Metodológicas e Perspectivas de Avanço sobre a Mudança Constitucional”. p. 1-32 , 2014.

NUNES, Felipe. (2009), "Governos De Coalizão E Resultados De Soma Positiva Em Minas Gerais E No Rio Grande Do Sul 1999-2006”. p. 1-124 , 2009.

OATES, Wallace E. (1999) "An Essay on Fiscal Federalism". Journal of Economic Literature v. 37, n. 3, p. $1120-1149,1999$

OATES, Wallace E. (2005) "Toward A Second-Generation Theory of Fiscal Federalism". International Tax and Publice Finance v. 12, n. 4, p. 349-373, 2005. Disponível em: <http://link.springer.com/article/10.1007/s10797-005-1619-9>.

PERNAMBUCO, Constituição. (1989). Emenda Constitucional n. 16, de 04 de Junho de 1999. "Adapta a Constituição do Estado as modificações introduzidas pelas Emendas no. 19 e 20 à Constituição da República, e dá outras providências". Recife, 1999. 
RASCH, Bjorn Erik, (2003) "Rigidity in Constitutional Amendment Procedures", in Eivind Smith, ed. "The Constitution as an Instrument of Change", Stockholm; SNS Forlag, 2003, pp. 111-25, at 121

RASCH, Bjorn Erik.(2008) "Foundations of Constitutional Stability: Veto Points, Qualified Majorities, and Agenda-Setting Rules in Amendment Procedures". Unpublished Manuscript p. 1$45,2008$.

RAZALI, Nornadiah Mohd; WAH, Yap Bee. (2011) "Power comparisons of Shapiro-Wilk , Kolmogorov-Smirnov, Lilliefors and Anderson-Darling tests." Journal of Statistical Modeling and Analytics v. 2, n. 1, p. 21-33, 2011

RIKER, W. (1975). "Federalism”. In: Greenstein, F \& Polsby, N. (eds.). Handbook of Political Science.

RODDEN, Jonathan (2005). "Federalismo e Descentralização em perspectiva comparada: sobre significados e medidas". Revista de Sociologia Política, Curitiba, n.24, p.9-27, jun 2005.

RODDEN, Jonathan; Rose-Ackerman, Susan (1997). “Does Federalism Preserve Markets?”. Faculty Scholarship Series. Paper 590. http://digitalcommons.law.yale.edy/fss_paper 590.

SANDES-FREITAS, Vítor E. V., MASSONETTO, Ana Paula. (2012). "Coligações e coalizões governamentais nos estados brasileiros: análise dos casos de São Paulo e do Piauí (19942010)". in $36^{\circ}$ encontro anual da ANPOCS.

SANTOS, Fabiano (2001). "O Poder Legislativo nos Estados: Diversidade e Convergência". Rio de Janeiro, Editora FGV

SHUGART, Matthew Soberg e CAREY, John M. (1998) "Calling out the Tanks or Filling out the Forms?" in CAREY, John M., SHUGART, Matthew Soberg, editors (1998) "Executive Decree Authority". New York: Cambridge University Press.

SHAPIRO, S.S; WILK, M.B. (1965). "An Analysis of Variance Test for Normality (Complete Samples)" Biometrika, Vol. 52, No. 3/4, pp. 591-611.

SILVA, Fábio Lacerda (2012). "Seriam as Assembleias Legislativas Irrelevantes? Presidencialismo Estadual e Participação Legislativa em São Paulo (2003-2006)”.

SILVA, Fábio Lacerda (2013). "Medindo a influência da Assembleia Legislativa Paulista na Produção de leis Estaduais (2007-2010)".

SOUZA, Celina (2004). "Subnational Constitucionalism in Brazil: Taxing, Spending and Borrowing". In "Federalism and Subnatinal Constitutions: Designs and Reforms". Março 22-27. Bellagio, Itália.

(2005). "Federalismo, Desenho Institucional e Instituições Federativos no Brasil pós1988". Revista de Sociologia Política, Curitiba, n. 25, p.105-121, jun. 2005.

STEPAN, Alfred (1999). "Para uma nova Análise Comparativa do Federalismo e da Democracia: Federações que Restringem ou Ampliam o Poder da Demos", in: Dados, v. 42, n.2, 197-251

TEMER, Michel; (1998) "Elementos de Direito Constitucional". São Paulo: Malheiros Editores. 1998.

TOMIO, Fabrício; RICCI, Paolo (2012a). "O Governo Estadual na Experiência Política Brasileira: os Desempenhos Legislativos das Assembleias Estaduais". Rev. Sociol. Polit., vol. 20, no. 41, pp. 193217.

(2012b) "Seis décadas de processo legislativo estadual: processo decisório e relações Executivo/Legislativo nos Estados (1951-2010)" in Cadernos da Escola do Legislativo, Vol. 13, n. 21, p. 59-107 jan/jun 2012. 
TSEBELIS, George; NARDI, Dominic J. (2014) "A Long Constitution is a (Positively) Bad Constitution: Evidence from OECD Countries", British Journal of Political Science p. 1-22 , 2014. Disponível em: http://www.journals.cambridge.org/abstract_S0007123414000441

VIANNA, Luiz Werneck; BURGOS, Marcelo Baumann; SALLES, Paula Martins. (2007) "Dezessete anos de judicialização da política". Tempo Social v. 19, n. 2, p. 39-85, 2007.

VOIGT, Stefan.(2009) "Explaining constitutional garrulity". International Review of Law and Economics, v. 29, n. 4, p. 290-303, 2009.

WEINGAST, Barry R.(2009) "Second generation fiscal federalism: The implications of fiscal incentives". Journal of Urban Economics v. 65, n. 3, p. 279-293, 2009. Disponível em: <http://inkinghub.elsevier.com/retrieve/pii/S0094119008001265>

WEINGAST, Barry R. (2014) "Second Generation Fiscal Federalism: Political Aspects of Decentralization and Economic Development". World Developmentv. 53, p. 14-25, 2014. Disponível em: <http://dx.doi.org/10.1016/j.worlddev.2013.01.003> 


\section{Apêndice A - Características das variáveis}

\section{A.1 Opções metodológicas na definição das variáveis}

Para medir o tamanho das Constituições os textos constitucionais de cada estado foram levantados, o que possibilitou a construção de diferentes bancos de dados. No caso dos artigos e palavras os bancos são a contagem, explicada nos tópicos adiante, do elemento relevante. Para os dispositivos o esforço foi primeiro em dividir todas as Constituições Estaduais em dispositivos, o que gerou um banco de dados com 32.875 observações. A partir das quais uma tabela de referência cruzada que consiste na contagem de dispositivos por Unidade Federativa foi utilizada como a principal base de dados para as análises pertinentes aos dispositivos, no entanto quando necessário ou mais significativo foram utilizados os dados de origem. As três variáveis representam então a contagem de algum elemento pertinente. Portanto foram tratadas como variáveis discretas organizadas em nível de escala. Isto inviabiliza, ou prejudica, a aplicação de estatísticas e medidas típicas das variáveis contínuas, mas violamos esta condição e algumas destas medidas foram utilizadas e aplicadas com o objetivo de explorar e descrever as variáveis.

Os dados podem receber dois tipos de tratamento. Por um lado podemos considerar que o conjunto das 27 Constituições Estaduais ${ }^{111}$ corresponde à população de Constituições Estaduais do Brasil, promulgadas após 1989, portanto o banco não seria então um banco amostral, mas sim um banco populacional, o que remove o sentido das análises de significância e intervalos de confiança bem como estimadores populacionais, já que com a população calculamos diretamente parâmetros populacionais. Aqui os dados seriam tratados como população de tamanho conhecido.

Por outro lado pode-se considerar que o conjunto das 27 Constituições Estaduais corresponde a uma amostra das Constituições Estaduais brasileiras, ou mesmo uma amostra de Constituições escritas no mundo, sendo o conjunto então uma amostra, e não uma população. Se tratado como amostra possui a vantagem de

111 Consideramos que o objeto de análise é a Constituição Estadual. Poderíamos também considerar que a unidade relevante são os dispositivos, o que ensejaria outros tipos de abordagem e análises. $O$ tamanho do banco permitiria a seleção de amostras aleatórias de uma população de dispositivos e testes mais significativos. 
possibilidade de generalização, estimação e testes estatísticos. No entanto ao tratar como amostra a questão do viés deve ser considerada bem como torna-se necessário inferir os parâmetros populacionais, perdendo assim informação. O critério utilizado para a coleta de dados foi a condição de ser uma Constituição Estadual brasileira promulgada após a promulgação de Constituição de 88 (05/10/1988). Portanto ocorre viés de seleção, já que não foi amostra aleatória. Então seja porque não corresponde a uma amostra fiel das Constituições Estaduais brasileiras (todas as já existentes, não só pós 1989), ou porque não corresponde a uma amostra representativa dos Textos Constitucionais no geral, tratar os dados como amostra incorre em viés de seleção. Desta forma quando tratamos como amostra, esta não é representativa da população.

Encontramos as informações de 26 das 27 Unidades Federativas, não encontramos dados referentes ao Acre. Portanto pode também ser tratado como uma amostra de 26 observações de uma reduzida população de 27 indivíduos, o que necessitaria de tratamento de amostra de populações finitas e conhecidas. Se utilizada a correção para populações finitas o tamanho ótimo da amostra seria também de 26 observações.

A definição e opção por qualquer um desses tratamentos incorrerá em custos e benefícios para a análise desenvolvida bem como pode ser embasado segundo diferentes perspectivas. Sendo assim optamos por tratar os textos constitucionais como amostra de população finita e não conhecida. A inferência e estimação de valores populacionais não será o foco, mas sim a descrição e apresentação dos dados encontrados, o problema de tratamento dos dados não é fundamental para o desenvolvimento do texto. A exploração dos dados considera-os uma amostra, mas dada a situação de indefinição deve-se ter cuidado com a interpretação e relevância analítica e estatística dos coeficientes e testes realizados e explicitados. Embora a capacidade de inferência seja prejudicada, a descritiva não o é.

\section{A.2 Artigos}

A amostra contém 26 observações, correspondentes a cada uma das Unidades Federativas, com exceção do Acre devido à falta de dados disponíveis. A extensão constitucional foi medida como o número total de artigos (corpo principal mais ADCT) dos textos constitucionais no ato da promulgação. 
Como alternativa robusta à média também encontramos a mediana, na mesma linha como alternativa ao desvio padrão e coeficiente de variação utilizamos como medidas robustas de dispersão o intervalo interquartil, os desvios medianos absolutos da mediana (MADM) e, análogo ao coeficiente de variação, o RMADM. Enquanto o intervalo gerado pelo $M A D M$ é centralizado na mediana, o intervalo interquartil determina o centro da distribuição como um todo. Então se o intervalo gerado pelo MADM indica que $50 \%$ das observações estão mais próximas da mediana do que o valor do MADM e o intervalo interquartil indica a metade das observações centrais, então em uma distribuição perfeitamente simétrica essas medidas coincidem. A Tabela A.2.1 contém o sumário das estatísticas descritivas e o Gráfico A.1, em seguida, expõe os gráficos exploratórios e descritivos ${ }^{112}$ da variável.

Tabela A.1 - Medidas descritivas da Extensão Constitucional medida em artigos.

\begin{tabular}{lccccc}
\hline & Média & $\begin{array}{c}\text { Desvio } \\
\text { Padrão }\end{array}$ & $\begin{array}{c}\text { Coeficiente } \\
\text { de Variação }\end{array}$ & Máximo & Mínimo \\
\hline $\begin{array}{l}\text { Constituição } \\
\begin{array}{l}\text { Texto } \\
\text { Principal }\end{array}\end{array}$ & 326,50 & 72,44 & $22,19 \%$ & 461 & 181 \\
ADCT & 274,62 & 59,93 & $21,82 \%$ & 369 & 207 \\
\hline & Mediana & MADM & RMADM & Q1 & Q3 \\
\hline $\begin{array}{l}\text { Constituição } \\
\text { Texto }\end{array}$ & 334 & 37 & $11,08 \%$ & 304 & 376 \\
Principal & 278,50 & 24,50 & $8,80 \%$ & 253 & 298 \\
ADCT & 50,50 & 10 & $19,80 \%$ & 42 & 63 \\
\hline
\end{tabular}

${ }^{112}$ Seleção da largura e número de intervalos dos histogramas, para todas as variáveis, segundo critério de Freedman-Diaconis (FREEDMAN; DIACONIS, 1981; HYNDMAN, 1995). 
A comparação entre o intervalo gerado pelo MADM (297 a 371) e o intervalo interquartil (304 a 376) sugere simetria, enquanto o diagrama de caixa indica ligeira assimetria à direita, logo positiva. No entanto o valor encontrado difere do intuído do gráfico, o que pode ser consequência de tentar calcular a assimetria em uma variável discreta. As medidas de formato encontradas foram assimetria de -0,57 (SE =0,456) e curtose de $-0,073(\mathrm{SE}=0,887)$, a primeira indica distribuição assimétrica à esquerda,
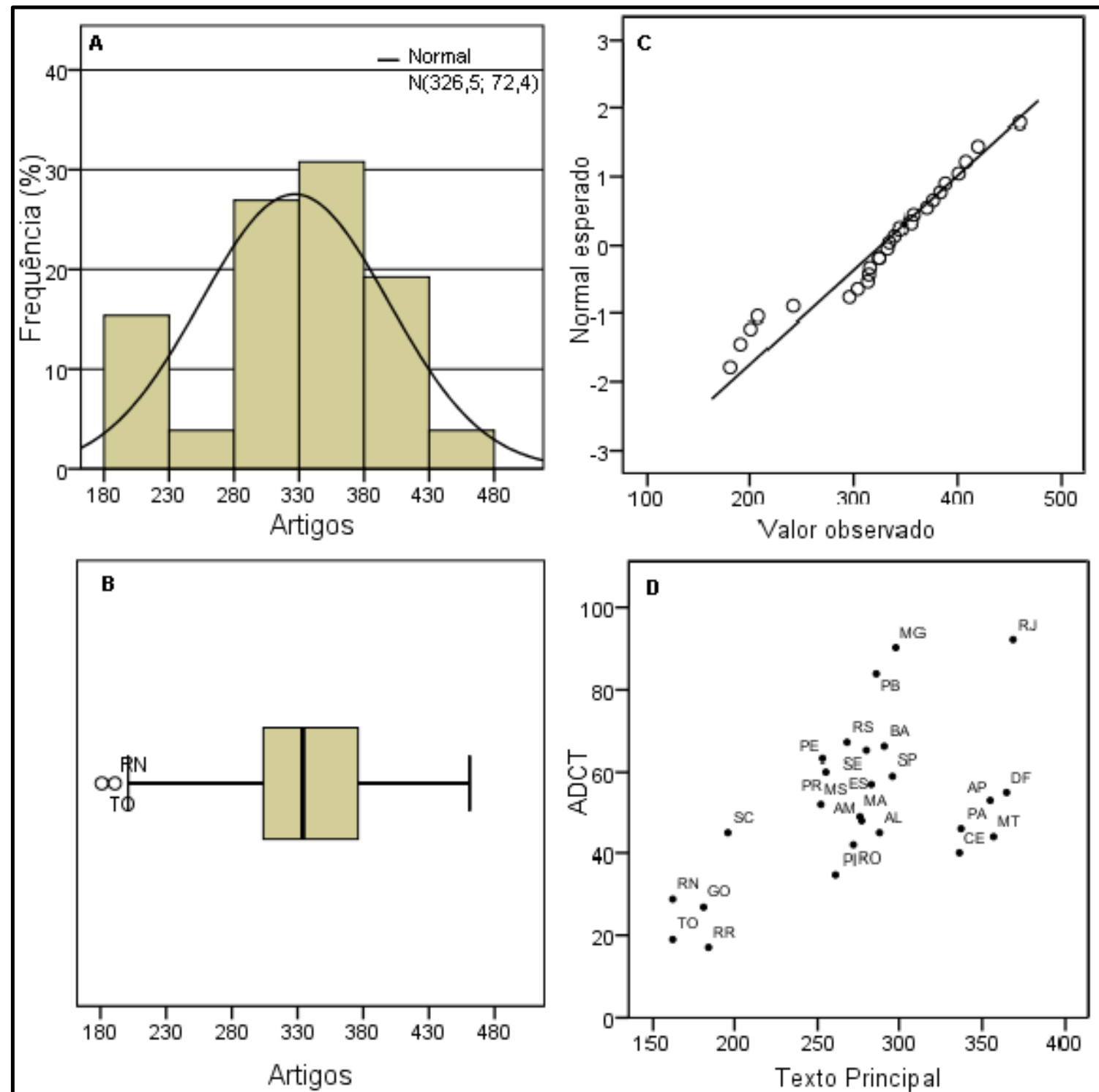

Gráfico A.1 -Gráficos exploratórios e descritivos da quantidade de artigos.

A: Histograma de total de artigos.

B: Diagrama de caixa de total de artigos.

C: Gráfico Q-Q normal de total de artigos.

D: Diagrama de dispersão entre ADCT e texto principal de cada Constituição estadual.

contrário do encontrado no gráfico. Mas não há evidência estatística para rejeitar a hipótese de que não são iguais a zero em nível de significância de $5 \%$, o que sugere 
a possibilidade de aproximação dos dados por uma curva normal (CRAMER; HOWITT, 2004; DOANE; SEWARD, 2011). Inspeção visual do histograma, diagrama em caixa e gráfico Q-Q normal reforçam essa possibilidade. Sendo assim a amostra foi submetida a teste de Shapiro-Wilk ( $p=0,129$ ) (Shapiro e Wilk, 1965; Razali e Wah, 2011), com significância de 5\% não é possível rejeitar a hipótese nula do teste. Isto é, não há evidência estatística para rejeitar a hipótese de que a amostra pode ser aproximada por uma normal. Ao replicar o teste de normalidade para o texto desagregado também não foi possível rejeitar a hipótese nula para o corpo principal ou para o ADCT. É importante ressaltar que não rejeitar a hipótese de normalidade não significa que ela foi aceita, portanto não podemos afirmar que há normalidade nos dados.

Quando as Constituições são desagregadas, o gráfico de dispersão sugere possibilidade de associação entre o tamanho do texto principal e o tamanho do ADCT de cada estado. Encontramos um coeficiente de correlação de Pearson de 0,533 ( $p=$ 0,03), como não há pressuposto de normalidade da variável esta medida de associação fica prejudicada. $O$ coeficiente de postos de Spearman de 0,468 ( $p=$ 0,016), o que indica associação monotônica entre essas variáveis. Mesmo com indícios de associação linear no gráfico de dispersão não é possível afirmar que há correlação significativa, mas há correlação monotônica.

\section{A.3 Palavras}

A amostra contém 26 observações correspondentes ao número de palavras em cada Constituição avaliada. Para a contagem das palavras deve-se primeiro definir o que se compreende por "contagem de palavras". A forma imediata de contar o número de palavras é pela utilização de programas de edição de texto (TSEBELIS; NARDI, 2014), no entanto, ao utilizar esse método é possível que o valor seja sobrestimado. Nestes programas o número de palavras é contado por meio da soma de conjuntos de um ou mais caracteres entre dois espaços, então sinais gráficos como travessão, parágrafo e indicador ordinal, serão contados como palavras. Ao remover os sinais gráficos da contagem o número de palavras fica 9,3\% menor. Optamos por instrumentalizar a variável como função do número de espaços uma vez que não há alteração no resultado e maior facilidade na contabilização. A variável corrigida é 
calculada como um mais ${ }^{113}$ a contagem do número de espaços (não consecutivos) entre conjuntos de um ou mais caracteres, excluídos os sinais gráficos. Outros elementos textuais excluídos foram os Preâmbulos e os indicadores de Artigo, parágrafo, inciso e alínea, já que entendemos que estes, quando contabilizados, alteram o número de palavras sem que informação adicional seja inserida.

A Tabela A.2 contém o sumário das estatísticas descritivas, em seguida 0 Gráfico A.2 expõe alguns gráficos exploratórios.

Tabela A.2 - Medidas descritivas da Extensão Constitucional medida em palavras

\begin{tabular}{lccccc}
\hline & Média & $\begin{array}{l}\text { Desvio } \\
\text { Padrão }\end{array}$ & $\begin{array}{l}\text { Coeficiente } \\
\text { de Variação }\end{array}$ & Máximo & Mínimo \\
\hline $\begin{array}{l}\text { Constituição } \\
\begin{array}{l}\text { Texto } \\
\text { Principal }\end{array}\end{array}$ & $32.030,88$ & $6.966,92$ & $21,75 \%$ & 45.206 & 15.132 \\
ADCT & $3.480,23$ & $1.678,83$ & $48,24 \%$ & 8.475 & 645 \\
\hline & Mediana & MADM & RMADM & Q1 & Q3 \\
\hline $\begin{array}{l}\text { Constituição } \\
\text { Texto }\end{array}$ & $30.582,50$ & 4.768 & $15,59 \%$ & 27.735 & 38.176 \\
Principal & 27.014 & 4.052 & $15,00 \%$ & 24.067 & 32.956 \\
ADCT & 3.325 & 847 & $25,47 \%$ & 2.458 & 3.845 \\
\hline
\end{tabular}

${ }^{113}$ Adicionamos a constante um ao número de palavras já que o número de espaços é sempre inferior em uma unidade ao número de palavras. Uma expressão de uma palavra contém zero espaços, duas palavras contém um espaço e assim sucessivamente. Ao somar uma unidade corrigimos esta distorção. 

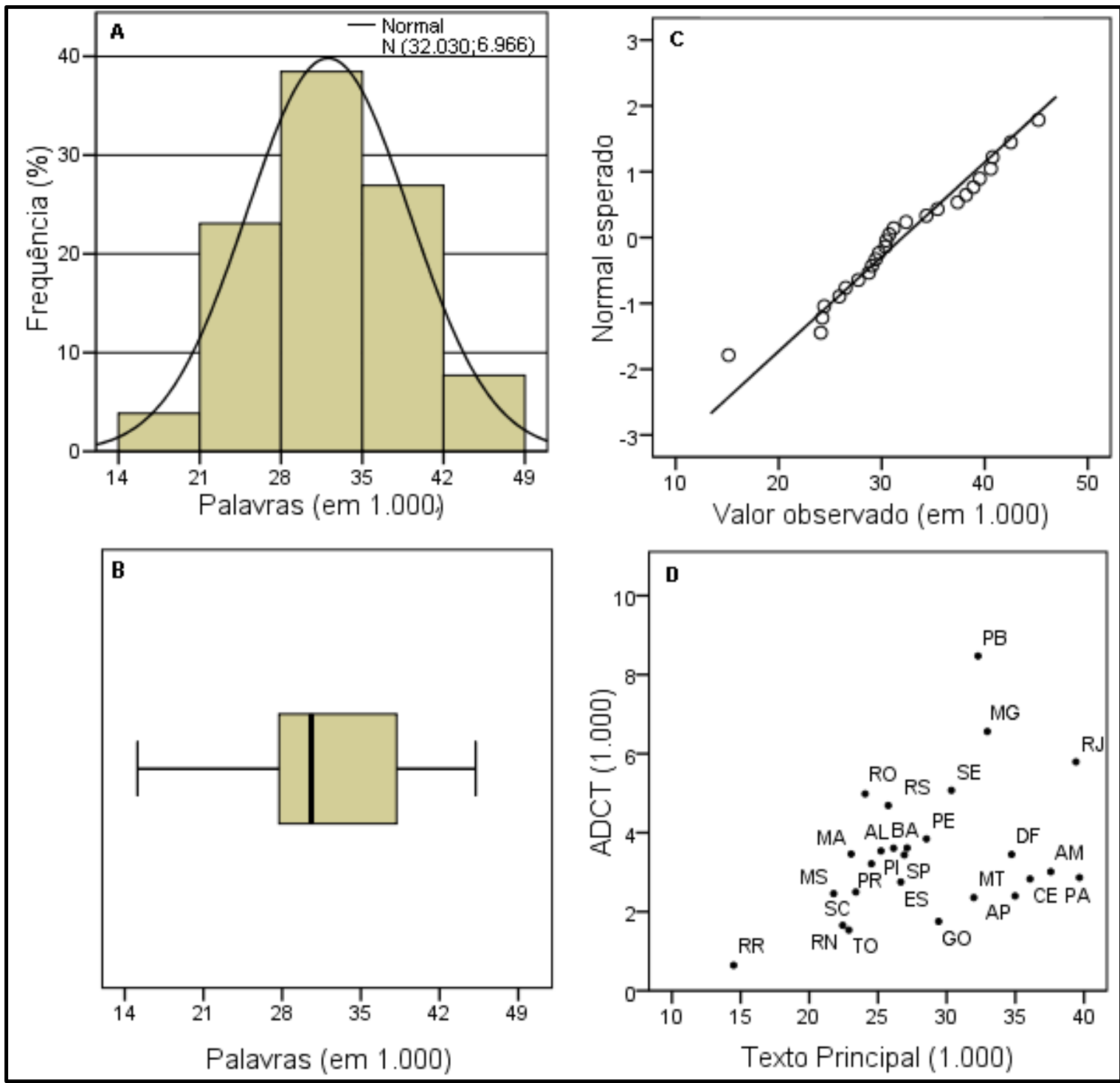

Gráfico A.2 - Gráficos exploratórios e descritivos da quantidade de palavras (em 1.000).

A: Histograma de total de palavras.

B: Diagrama de caixa de total de palavras.

C: Gráfico Q-Q normal de total de palavras.

D: Diagrama de dispersão entre quantidade de palavras no ADCT e texto principal de cada Constituição estadual.

A comparação dos intervalos gerados pelo MADM (25.814 a 35.350) e intervalo interquartil (27.735 e 38.176) sugere assimetria à direita, na mesma linha o diagrama de caixa a distribuição aparenta assimetria à direita, com $25 \%$ das observações concentradas entre primeiro quartil e mediana em um intervalo de 2.848 palavras. Em contrapartida o histograma se aproxima de uma distribuição simétrica, quando calculada a assimetria possui valor negativo, ou assimétrica à esquerda. $O$ coeficiente de assimetria é de $-0,116$ ( $\mathrm{SE}=0,456)$ e curtose de $-0,011$ (SE =0,887), não podemos rejeitar a hipótese de que essas medidas de formato são diferentes de 
zero, com 5\% de significância. Portanto a contraposição encontrada entre 0 coeficiente de assimetria e o diagrama de caixa advém de problemas naquele. Já que não só não rejeitamos a hipótese como também sofre alteração devido à natureza discreta dos dados.

Seguindo com a inspeção de histograma, diagrama de caixa e gráfico $Q-Q$ normal, o diagrama de caixa não apresenta características de normalidade, enquanto o gráfico Q-Q, com exceção do ponto inferior, e o histograma apresentam características de distribuição normal. Quando formalizado com teste de Shapiro-Wilk ( $p=0,637)$ há forte evidência estatística de que não podemos rejeitar a hipótese nula (segue uma normal). Entretanto forte evidência a não rejeitar a hipótese não é o mesmo que forte evidência para aceitar, então não é estatisticamente possível - com os testes realizados - afirmar que o número de palavras se aproxima de uma distribuição normal. Contudo os indícios, baseados nos gráficos, medidas de formato, medidas de posição e teste de Shapiro-Wilk, indicam o contrário. Quando a mesma análise é repetida para o texto desagregado, não é possível rejeitar a hipótese de normalidade para a quantidade de palavras no texto principal, entretanto rejeitamos a hipótese de que a quantidade de palavras no ADCT pode ser aproximada por uma curva normal.

Embora o gráfico de dispersão não sugira associação, para manter a equivalência das análises a correlação foi formalizada. O coeficiente de correlação de Pearson entre os dois segmentos do texto constitucional é de 0,378 ( $p=0,057)$ e o rô de Spearmen é 0,333 ( $p=0,097)$. Nenhuma das correlações é significativa no nível de $5 \%$, portanto não podemos rejeitar a hipótese de que as correlações sejam diferentes de zero, isto é, não há correlação linear ou monotônica estatisticamente identificável. Como rejeitamos a normalidade do ADCT, o pressuposto de normalidade é violado, portanto a correlação de Pearson é prejudicada, o que pode afetar a significância do coeficiente.

\section{A.4 Dispositivos}


A Metodologia de Análise Constitucional, definida por Arantes e Couto (2005; 2006; 2010) tem por objetivo dividir os textos constitucionais em unidades lógicas, em comandos jurídicos completos, denominados dispositivos. Para tanto é necessário observar a estrutura sintática dos tópicos constitucionais. Do ponto de vista sintático, os artigos e suas subdivisões - parágrafos, incisos, alíneas e itens - são encontrados em duas estruturas. Podem formar orações autônomas, ou, conjuntamente com outros trechos (caput, parágrafo, inciso ou alínea) exercer função sintática ${ }^{114}$, de forma que apenas a associação destes elementos forma uma oração completa dotada de significado. Então, cada divisão de um artigo não necessariamente contém alguma informação ou comando legal completo, pode necessitar complementos e estruturas sintáticas para que forme uma oração e não uma frase. A ausência de núcleo verbal impede que se estabeleça relação semântica sem elementos extratextuais e, com exceção das frases assertivas, configuram enunciado incompleto ou são fragmentos de próprios da linguagem oral (BECHARA, 2009).

Ao medir as Constituições em número de dispositivos, estamos interessados nas orações completas, sejam autônomas ou não. A natureza sintática da frase deve ser observada, uma vez que se não formar oração completa, haverá outro tópico (superior ou inferior) que a completará. Não há casos em que dois tópicos, de mesmo nível ou de origens distintas, que estabelecem relação complementar ou necessária no sentido sintático. Na contagem de dispositivos o artigo é então um dos limites da instrumentalização da variável, é na organização sintática da hierarquia vertical de um artigo que os dispositivos serão encontrados. Não há artigos com menos de um dispositivo, nem dispositivos compostos por mais de um artigo, o dispositivo é a menor fração de um artigo.

Um dispositivo pode ser identificado a partir das subdivisões (quando existentes) dos artigos, já que se não formarem oração completa, autônoma, necessitam de outros fragmentos para que obtenham significado sintático e portanto capacidade de intepretação sem utilização de elementos extratextuais. Quando um tópico constitucional consiste apenas em estrutura sintática sem função definida ou sem núcleo, haverá de se associar com outro tópico, de hierarquia superior ou inferior, para que juntos formem uma oração e consequentemente obtenham significado

${ }^{114}$ Sujeito, predicado, objeto, entre outros. 
jurídico e possibilidade de interpretação sem utilização de contexto extratextual. As condições para que um conjunto composto por um ou mais tópicos sejam caracterizados como dispositivos são: 1) Forma pelo menos uma oração; 2) Não encontram-se tópicos, acima ou abaixo do dispositivo em questão, cuja função sintática se dá pela associação ${ }^{115}$.

A instrumentalização da variável é exemplificada pelo Art. 157 da Constituição da Paraíba, transcrito a seguir. Diversas partes do artigo foram omitidas com o objetivo de sintetizar a aplicação do método à diferentes situações encontradas.

Art.157 - É vedado ao Estado e aos Municípios, sem prejuízo de outras garantias asseguradas ao contribuinte:

I-exigir ou aumentar tributos sem lei que os estabeleça;

III-cobrar tributos:

a) em relação a fatos geradores ocorridos antes do início da vigência da lei que os houver instituído ou aumentado;

$\S 5^{\circ}$-As normas do processo administrativo fiscal subordinam-se ao princípio da reserva legal. (PARAÍBA, 1989)

Seguindo princípio de que um dispositivo forma um enunciado jurídico dotado de significado, e satisfaz as duas condições citadas, o trecho destacado conta com três dispositivos e cinco tópicos. Após a organização do trecho em dispositivos, e agregação em períodos completos, temos a seguinte estrutura:

a. [Caput] É vedado ao Estado e aos Municípios, sem prejuízo de outras garantias asseguradas ao contribuinte, [Inciso l] exigir ou aumentar tributos sem lei que os estabeleça;

b. [Caput] É vedado ao Estado e aos Municípios, sem prejuízo de outras garantias asseguradas ao contribuinte, [Inciso III] cobrar tributos [alínea a] em relação a fatos geradores ocorridos antes do início da vigência da lei que os houver instituído ou aumentado;

c. $\left[\S 5^{\circ}\right]$ As normas do processo administrativo fiscal subordinam-se ao princípio da reserva legal;

${ }^{115}$ Isto é, não é objeto, sujeito, predicado, ou outra estrutura sintática que necessita de outro tópico para sua caracterização. 
Nesta organização temos três expressões formadas por uma ou mais orações, que compõe pelo menos um comando ou instrução jurídica. O procedimento para alcançar tal resultado tem seu início na análise do caput. Este contém duas orações, uma oração principal e uma subordinada, no entanto, sua estrutura sintática é incompleta. O Inciso I, isoladamente, não forma oração com sentido sintático, é apenas com associação com o caput, já que corresponde a orações subordinadas à oração principal presente neste. O primeiro dispositivo corresponde à agregação de caput e inciso I, o que satisfaz ambas condições. Da mesma forma o Inciso III forma oração subordinada à mesma oração principal contida no caput, no entanto, a condição dois não é satisfeita em virtude da alínea a formar também oração subordinada. Então o segundo dispositivo é a agregação do caput, inciso III e alínea a em um mesmo período. Já o parágrafo quinto não estabelece relação sintática de subordinação ou dependência do caput, ou de outros tópicos, então, como oração autônoma, satisfaz ambas condições e é considerado dispositivo.

caput é repetido no segundo dispositivo, uma vez que só por meio de sua associação as condições são satisfeitas. Mas, a fruto de simplificação e redução da extensão ${ }^{116}$ e complexidade do banco de dados, as repetições desnecessárias foram omitidas, são portanto implícitas. No nosso exemplo o caput seria disposto apenas no primeiro dispositivo mesmo sendo omitido no segundo, mas a expressão é implícita, não há alteração do texto ou compreensão, apenas da extensão causada por repetição. Fundamentalmente isso causa alteração no número de palavras e elementos textuais dos dispositivos ${ }^{117}$, mas não da interpretação ou contagem.

A divisão do texto constitucional em dispositivos tem como vantagem a capacidade de quantificação e análise de enunciados lógicos. Portanto a barreira linguística é praticamente eliminada quando textos de línguas distintas são comparados. Também fornece critério formal para divisão do texto, que diferente da divisão em artigos, não está fundamentalmente subordinada à discricionariedade do constituinte. No entanto, como neste critério não são separadas as provisões, ideias e comandos jurídicos em si, uma vez que para isto uma análise aprofundada dos

\footnotetext{
116 Quando a repetição não é omitida o número de palavras total no banco aumenta em aproximadamente $30 \%$ sem que nova informação seja inserida.

117 O Art. 157 em questão possui ao todo 16 dispositivos que quando omitidas as repetições, contam com 361 palavras no total, quando não omitidas contém 544 palavras. Neste caso corresponde a aumento de $50 \%$ do número de palavras, sem que se altere a contagem de dispositivos.
} 
textos seria necessária, a variável sofre certa influência da redação e portanto do constituinte. Há casos em que uma constituição agrega duas provisões, dois enunciados jurídicos dotados de lógica, em um mesmo dispositivo, em um mesmo período, e outras que não. Isso se observa nos artigos segundo e doze da Constituição do Sergipe e Roraima, respectivamente.

Art. $2^{\circ}-[\ldots]$ Parágrafo único — Incluem-se entre os bens do Estado:
I- $[\ldots]$
II — as ilhas fluviais e lacustres;
III — as terras devolutas, quando não pertencentes à União. (SERGIPE, 1989)

Art.12. - Incluem-se entre os bens do Estado:

$I-[\ldots]$

II - as ilhas fluviais e lacustres e as terras devolutas situadas em seu território. (RORAIMA, 1989)

No trecho do artigo segundo de Sergipe identificamos dois dispositivos, consistem no parágrafo único associado com incisos I e II. Já na Constituição de Roraima, o artigo doze agregado ao Inciso II forma apenas um dispositivo. Embora a ideia expressa em ambos seja a mesma (com exceção do trecho referente à União), o número de dispositivos difere. Três provisões jurídicas são indicadas em ambos casos. Qual seja, as ilhas fluviais, as ilhas lacustres e as terras devolutas são bens do Estado. Mas, em Sergipe os constituintes redigiram as provisões em dois dispositivos, já em Roraima foram agregadas em apenas um dispositivo. $O$ trecho destacado também ilustra a discricionariedade dos constituintes quanto à organização dos artigos. Na Constituição de Sergipe a enumeração dos bens do Estado consta como parágrafo único de um artigo, já em Roraima um artigo é dedicado ao tema. Então a divisão em dispositivos acaba por não isolar totalmente a opção do constituinte por 
determinada forma de organização, mas como as subdivisões são consideradas, o faz de forma mais eficiente do que a divisão em artigos.

O banco de dispositivos constitucionais conta com 32.875 observações, cada observação corresponde a um dispositivo constitucional instrumentalizado pelo método descrito. Com o objetivo de medir o tamanho de cada Constituição Estadual a amostra foi organizada em uma tabela de referência cruzada, cujas observações são a Constituição de cada estado, e a variável a contagem de dispositivos na Constituição correspondente. O tamanho elevado do banco principal permite maior variedade de tratamento estatístico e análises mais robustas, no entanto, trabalhamos com o banco de contagens, uma vez que o interesse é na extensão constitucional, e não nos dispositivos em si, então contamos com 26 observações, correspondentes à contagem de dispositivos em cada Constituição.

A Tabela A.3 contém o sumário estatístico e em seguida a Gráfico A.3 expõe alguns gráficos exploratórios.

Tabela A.3 - Medidas descritivas da Extensão Constitucional medida em dispositivos.

\begin{tabular}{lccccc}
\hline & Média & $\begin{array}{l}\text { Desvio } \\
\text { Padrão }\end{array}$ & $\begin{array}{c}\text { Coeficiente } \\
\text { de Variação }\end{array}$ & Máximo & Mínimo \\
\hline $\begin{array}{l}\text { Constituição } \\
\begin{array}{l}\text { Texto } \\
\text { Principal }\end{array}\end{array}$ & $1.264,42$ & 259,85 & $20,55 \%$ & 1.661 & 610 \\
ADCT & $1.166,73$ & 235,08 & $20,15 \%$ & 1.541 & 587 \\
\hline & 97,69 & 43,21 & $44,23 \%$ & 228 & 23 \\
\hline Mediana & MADM & RMADM & Q1 & Q3 \\
$\begin{array}{l}\text { Texto } \\
\text { Principal }\end{array}$ & 1.103 & 137 & $13,18 \%$ & 1.121 & 1.541 \\
ADCT & 91,50 & 17,50 & $19,13 \%$ & 74 & 1.420 \\
\hline
\end{tabular}

Do MADM temos que três estados (11,5\%) possuem menos de 1.034 dispositivos e dez (38,5\%) possuem mais que 1.348 dispositivos. Quando comparamos o intervalo gerado pelo MADM e o intervalo interquartil há intersecção 
de dez dos treze estados de cada conjunto. Mas o intervalo dos desvios absolutos conta com 10 (38,5\%) estados entre seu limite inferior (1.034) e a mediana (1.191) e apenas três $(11,5 \%)$ estados entre a mediana e seu limite superior (1.348), o que indica formato bimodal.

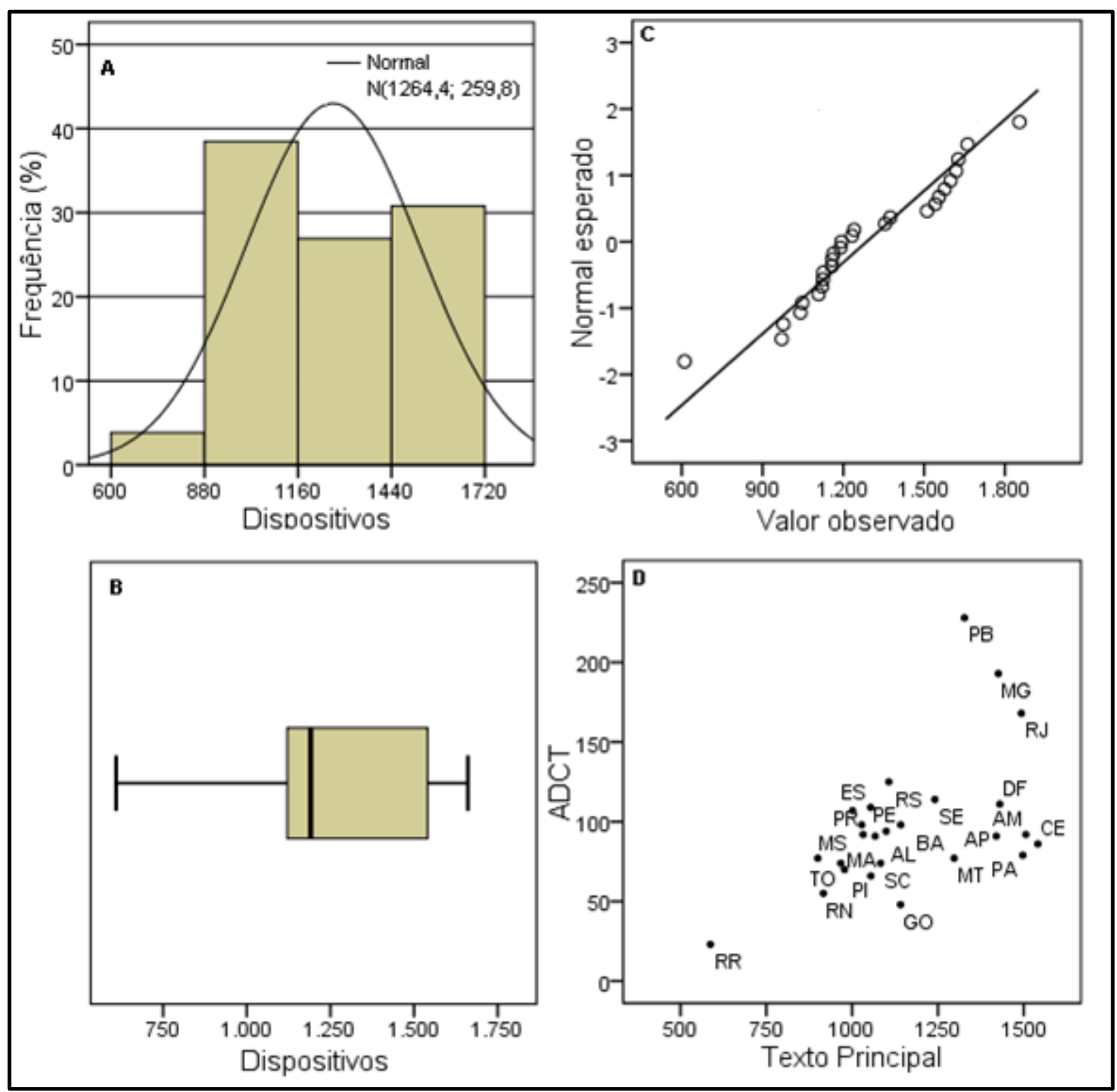

Gráfico A.3 - Gráficos exploratórios e descritivos da quantidade de dispositivos nas Constituições Estaduais.

A: Histograma de total de dispositivos por Constituição;

B: Diagrama de caixa de total de dispositivos por Constituição;

C: Gráfico Q-Q normal de total de dispositivos por Constituição;

D: Diagrama de dispersão entre quantidade de dispositivos no ADCT e texto principal de cada Constituição estadual;

O diagrama de caixa e histograma corroboram o formato bimodal com concentração de observações em duas faixas relativamente estreitas. A primeira, entre o primeiro quartil (1.121) e a mediana (1.191), cujo intervalo de 70 dispositivos 
contém sete observações (cerca de $25 \%$ do total). A segunda, entre o terceiro quartil (1.541) e o máximo (1.661), com intervalo de 120 dispositivos contém também sete observações. Portanto o número de dispositivos se organiza de forma bimodal. $\mathrm{O}$ primeiro pico (moda) se localiza no intervalo de 1.034 a 1.191 dispositivos (157 dispositivos), com 10 estados; o segundo pico se encontra entre o terceiro quartil e o máximo (120 dispositivos), com 7 estados.

Além de formato aparentemente bimodal, a natureza discreta dos dados faz com que as medidas de formato tradicionais sejam prejudicadas. Não obstante encontramos assimetria de $-0,203(\mathrm{SE}=0,456)$ e curtose de $-0,037$ (SE = 0,887). 0 coeficiente de assimetria indica distribuição assimétrica à esquerda, mas não podemos rejeitar a hipótese de que essas medidas não são iguais a zero. Mesmo que formalmente a assimetria e curtose não sejam estatisticamente diferentes de zero, a inspeção visual de histograma, diagrama em caixa e gráfico Q-Q normal não sugerem normalidade, e, quando formalizado com teste de Shapiro-Wilk ( $p=0,063)$, embora não haja evidência estatística para rejeitar a possibilidade de aproximação pela normal a 5\% de significância, o p-valor encontra-se muito próximo deste limiar. Com as medidas utilizadas nada se pode afirmar acerca da natureza da distribuição, mas os indícios apontam para ausência de normalidade e distribuição bimodal.

O gráfico de dispersão de dispositivos no ADCT e no corpo principal indica possibilidade de relação linear entre as variáveis. Encontramos coeficiente de correlação de Pearson de 0,51 ( $p=0,008)$, no entanto como não há pressuposto de normalidade o coeficiente de Pearson é prejudicado bem como seu teste de significância. Já o coeficiente de correlação de postos de Spearman é de 0,456 ( $p=$ 0,019), o que indica existência de relação monotônica entre as variáveis. Embora não haja fundamentos estritos para a remoção dos valores extremos ${ }^{118}$, quando 0 fazemos, não é possível encontrar correlação entre as variáveis e a nuvem torna-se dispersa.

\footnotetext{
118 Os maiores são PB, MG e RJ, e o menor é RR. No caso do ADCT os estados PB, MG e RJ são outliers, sendo PB ainda mais extremo. Ao removê-los encontramos coeficiente de Pearson próximo de zero e novamente não significativo e correlação de Spearman também próxima de zero e não significativa. O que indica que a possível correlação entre essas variáveis se dê em virtude dessas quatro observações. Um gráfico de dispersão com essas restrições também não parece indicar qualquer associação linear ou monotônica.
} 


\section{A.5 Comparação entre as variáveis}

A transformação linear efetuada teve como base a observação do banco de dados e proporção aparente entre as variáveis. Todavia um procedimento formal seria a razão entre cada observação a ser transformada e ó tamanho médio dos artigos, nesta mesma unidade. Ou seja, para transformarmos a quantidade de palavras para a escala dos artigos dividiríamos a quantidade de palavras na Constituição pela média de palavras encontrada nos artigos, e o mesmo procedimento para o caso dos dispositivos.

Como os artigos possuem em média 98,1 palavras e 3,9 dispositivos, a divisão por 100 e por 4, respectivamente, a fruto de facilitar a observação e os cálculos, não deve gerar distorções significativas. Ademais a transformação linear realizada, multiplicar pelas constantes 0,01 e 0,25 , não causa alteração nas estatísticas descritivas, exceto o efeito quadrático na variância. Possui efeito proporcional na média e não influencia as medidas de posição robustas ou os coeficientes de correlação. O sumário estatístico das variáveis transformadas se encontra na Tabela A.4.

Tabela A.4 - Sumário estatístico das variáveis transformadas

\begin{tabular}{lccccc}
\hline & Média & $\begin{array}{l}\text { Desvio } \\
\text { Padrão }\end{array}$ & $\begin{array}{c}\text { Coeficiente } \\
\text { de Variação }\end{array}$ & Máximo & Mínimo \\
\hline Artigos & 326,00 & 72,50 & $22,24 \%$ & 461 & 181 \\
$\begin{array}{l}\text { Dispositivos } \\
\text { (x0,25) }\end{array}$ & 316,10 & 65 & $20,56 \%$ & 415,25 & 152,50 \\
$\begin{array}{l}\text { Palavras } \\
\text { (x0,01) }\end{array}$ & 320,30 & 70 & $21,85 \%$ & 452,06 & 151,32 \\
\hline & Mediana & MADM & RMADM & Q1 & Q3 \\
\hline Artigo & 334 & 37 & $11,08 \%$ & 304 & 376 \\
$\begin{array}{l}\text { Dispositivos } \\
\text { (x0,25) }\end{array}$ & 298 & 39,25 & $13,17 \%$ & 280,25 & 385,25 \\
$\begin{array}{l}\text { Palavras } \\
\text { (x0,01) }\end{array}$ & 306 & 47,68 & $15,58 \%$ & 277,35 & 381,76 \\
\hline
\end{tabular}




\section{A.6 Agrupamentos}

Em virtude da diversidade de Títulos, Capítulos e Seções encontradas nas Constituições Estaduais o critério de recodificação não se utilizou de uma única Constituição como modelo. Optamos também por não utilizar a Constituição Federal como modelo não só em virtude de termos a comparação entre as Constituições Estaduais como foco, mas também ao utilizar a Constituição Federal como modelo básico poderíamos incorrer em viés ao compará-las com esta, uma vez que aquelas seriam encaixadas no modelo pronto da CF. O esforço se deu então em criar um critério de classificação com capacidade de agregar os diferentes artigos e temas presentes nas Constituições Estaduais sob agrupamentos equivalentes.

Para criar o critério listamos todos os Títulos, Capítulos, Seções e Subseções presentes nas Constituições Estaduais. Após a listagem completa identificamos as nomenclaturas mais comuns em cada nível de agrupamento de forma isolada. Com isso foi possível substituir aquelas diferenças que advém de utilização de estilo de escrita distinto (tempos verbais distintos, ordem direta ou ordem inversa, singular e plural, utilização de sinônimos ${ }^{119}$ ), que não são fundamentalmente agrupamentos de temas distintos, por uma nomenclatura comum. Ao replicar o procedimento para todos os Títulos, Capítulos, Seções e Subseções, conseguimos isolar os agrupamentos que são de fato distintos e quais são os mais comuns. Após a identificação das Subseções mais comuns, iniciamos o processo de reclassificação e agrupamentos das Subseções mais comuns sob as Seções mais comuns, e assim sucessivamente até a organização dos Títulos.

Com essa divisão foi possível construir um primeiro modelo com os agrupamentos e suas divisões mais comuns nas Constituições Estaduais de um lado, e os agrupamentos únicos ou pouco frequentes de outro. Com base neste modelo preliminar identificamos os temas mais frequentes dentro de cada agrupamento, do menor ao maior nível, com base nos artigos de cada Constituição. Com isso organizamos um modelo geral com nove títulos, vinte e cinco capítulos e trinta e cinco

119 Por exemplo, não há diferença real entre "Da Tributação e do Orçamento" e "Dos Tributos e dos Orçamentos". Esses Títulos, embora encontrados em Estados diferentes, e possuidores de nomenclaturas diferentes, são fundamentalmente a mesma expressão. 
seções. Optamos por não organizar subseções, estas foram integradas às seções pertinentes.

A última etapa do processo foi a classificação propriamente dita. A classificação se deu no nível dos artigos, para tanto, identificamos o tema principal em cada artigo das Constituições e os classificamos sob o agrupamento pertinente. Ao final do processo todos os artigos estarão sob um ou outro agrupamento, mas não necessariamente todo agrupamento conterá um artigo, e consequentemente os dispositivos daquele artigo serão também classificados sob o tema. Neste modelo não há necessidade de continuidade. Isto é, um agrupamento pode conter mais de um intervalo não contínuo de artigos. Como a identificação final foi sob os artigos, aqueles agrupamentos incomuns ou únicos, tais como "Da Liberdade de Consciência" ou "Das Proteções Especiais", desapareceram quando identificamos os temas tratados pelos artigos que os compõe. Com isso foi possível classificar integralmente as Constituições Estaduais sob um sistema único de agrupamento em Títulos, Capítulos e Seções. Com a classificação padronizada medimos os textos constitucionais em dispositivos. Ao final da sessão a Tabela A.7 expõe as estatísticas descritivas, seguida pelos Gráfico A.4 e Gráfico A.5 com gráficos exploratórios.

Quando a padronização foi aplicada à Constituição Federal, notamos que o modelo padronizado a partir das Constituições Estaduais e a divisão por Títulos na Constituição Federal promulgada foi equivalente. Isto é, dos dez Títulos na Constituição Federal, nove foram equivalentes aos padronizados. As diferenças foram que no caso Estadual optamos por agregar os Princípios, direitos e Garantias Fundamentais sob Título único, na Federal Os Princípios Fundamentais formam um Título e os Direitos e Garantias Fundamentais outro. A segunda diferença foi na nomenclatura, enquanto a Constituição Federal conta com o Título "Da Defesa do Estado e das Instituições Democráticas", sob a padronização Estadual encontramos "Da segurança Pública”, que é um capítulo do referido Título na Constituição Federal. Assim, o próprio processo de padronização forneceu mais indícios das semelhanças entre as cartas.

Utilizamos uma Análise de Variância Simples (ANOVA) com o objetivo de avaliar se a quantidade de dispositivos difere entre os Títulos padronizados. As observações são a extensão de um conjunto de dispositivos pertencentes a uma 
unidade federativa e classificados segundo um Título padronizado. A variável de resposta é a extensão em dispositivos, a variável independente é a classificação sob um dos nove Títulos padronizados. A Tabela A.5 contém as médias e desvios padrão para cada nível de Título.

Tabela A.5 - Médias e Desvios Padrão da quantidade de dispositivos por Título

\begin{tabular}{lccc}
\hline Título & N & Média & Desvio Padrão \\
\hline 1. Dos Princípios, Direitos e & 26 & 25,81 & 20,67 \\
Garantias Fundamentais & 26 & 213,85 & 60,52 \\
2. Do Estado & 26 & 421,50 & 55,84 \\
3. Da Organização dos Poderes & 26 & 24,04 & 8,00 \\
4. Da Segurança Pública & 26 & 121,46 & 41,20 \\
5. Da Tributação e Orçamento & 26 & 118,35 & 60,45 \\
6. Da Ordem Econômica & 26 & 217,50 & 71,16 \\
7. Da Ordem Social & 26 & 24,23 & 24,01 \\
8. Disposições Constitucionais & 26 & 97,69 & 43,21 \\
Gerais & 234 & 140,49 & 47,30 \\
\hline 9. ADCT & & & \\
\hline Total &
\end{tabular}

Assimetria e curtose padronizadas indicaram que os dados não são normais quando considerados em conjunto. Quando divididos pelas categorias de Título, rejeitamos a normalidade dos Títulos 1,8 e 9 pelas assimetrias e curtoses padronizadas. Teste de Shapiro-Wilk rejeitou a normalidade para os Títulos 1 ( $p=$ $001) ; 5(p=, 029), 8(p=, 004)$ e $9(p=, 003)$. Não só o procedimento é resistente à desvios de normalidade, mas também os grupos possuem mesma quantidade de observações, portanto a violação da normalidade não deve gerar desvios significativos. Um teste $\mathrm{F}$ de Levene revela que rejeitamos a homogeneidade de variâncias $(p<, 001)$, portanto o teste $F$ de Welch foi utilizado.

A análise de variância mostra que a diferença na extensão dos Títulos é estatisticamente significante, Welch $F(8 ; 88,54)=226,36, p<, 001$. O ômega quadrado 
estimado $\left(\omega^{2}=0,88\right)$ indica que aproximadamente $88 \%$ da variação total na quantidade de dispositivos pode ser atribuída às categorias de Títulos.

Utilizamos o procedimento post hoc de Games-Howell com o objetivo de determinar quais pares de Títulos apresentaram média de dispositivos significativamente diferentes. A Tabela A.6 expõe os resultados do teste. Identificamos quatro subconjuntos de Títulos equivalentes. São eles: (a) 1, 4 e 8; (b) 6, 5 e 9; (c) 2 e 7; (d) 3. Estes estão ordenados do menor para o maior. Isto é, os Títulos do conjunto (a) não apresentam diferenças estatisticamente significantes entre si e são sistematicamente menores que os Títulos do (b); os Títulos do conjunto (b) não apresentam diferença estatisticamente significante entre si e são sistematicamente menores que os Títulos do conjunto (c). Notamos que o conjunto (c), formado apenas pelo Título 3 (da Organização dos Poderes) é consideravelmente maior que todos os outros Títulos e não se aproxima de nenhum deles. Das intensidades de Cohen vemos que no geral os efeitos são significativamente fortes.

Tabela A.6 - Resultados do teste post hoc de Games-Howell para quantidade de dispositivos por Título.

\begin{tabular}{|c|c|c|c|c|c|c|c|c|c|}
\hline \multicolumn{10}{|c|}{ Diferença entra as Médias (Intensidade do efeito de Cohen parênteses,) } \\
\hline \multicolumn{2}{|c|}{ Título } & 2 & 3 & 4 & 5 & 6 & 7 & 8 & 9 \\
\hline 1 & - & & & & & & & & \\
\hline 2 & $\begin{array}{c}-188,038^{*} \\
(4,15)\end{array}$ & - & & & & & & & \\
\hline 3 & $\begin{array}{c}-395,69^{*} \\
(9,39)\end{array}$ & $\begin{array}{c}-207,65^{\star} \\
(3,566)\end{array}$ & - & & & & & & \\
\hline 4 & 1,76 & $\begin{array}{l}189,8^{*} \\
(4,39)\end{array}$ & $\begin{array}{c}397,45^{\star} \\
(9,96)\end{array}$ & - & & & & & \\
\hline 5 & $\begin{array}{c}-95,65^{\star} \\
(2,93)\end{array}$ & $\begin{array}{l}92,38^{*} \\
(1,78)\end{array}$ & $\begin{array}{l}300^{*} \\
(6,11)\end{array}$ & $\begin{array}{c}-97,42^{\star} \\
(3,28)\end{array}$ & - & & & & \\
\hline 6 & $\begin{array}{c}-92,53^{*} \\
(2,04)\end{array}$ & $\begin{array}{l}95,5^{\star} \\
(1,57)\end{array}$ & $\begin{array}{c}303,15^{*} \\
(5,2)\end{array}$ & $\begin{array}{l}-94,3^{*} \\
(2,18)\end{array}$ & 3,11 & - & & & \\
\hline 7 & $\begin{array}{c}-191,69^{*} \\
(3,65)\end{array}$ & $-3,65$ & $\begin{array}{l}204^{*} \\
(3,18)\end{array}$ & $\begin{array}{c}-193,45^{*} \\
(3,82)\end{array}$ & $\begin{array}{c}-96,038^{*} \\
(1,65)\end{array}$ & $\begin{array}{c}-99,154^{*} \\
(1,5)\end{array}$ & - & & \\
\hline 8 & 1,57 & $\begin{array}{l}189,6^{*} \\
(4,11)\end{array}$ & $\begin{array}{c}397,2^{*} \\
(9,24)\end{array}$ & $-0,192$ & $\begin{array}{l}97,23^{*} \\
(2,88)\end{array}$ & $\begin{array}{c}94,115 \\
(2,04)\end{array}$ & $\begin{array}{c}193,26^{*} \\
(3,63)\end{array}$ & - & \\
\hline 9 & $\begin{array}{c}-71,88^{*} \\
(2,12)\end{array}$ & $\begin{array}{c}116,15^{\star} \\
(2,2)\end{array}$ & $\begin{array}{c}323,8^{*} \\
(6,48)\end{array}$ & $\begin{array}{c}-73,654^{*} \\
(2,37)\end{array}$ & 23,69 & 20,654 & $\begin{array}{l}119,8^{*} \\
(2,03)\end{array}$ & $\begin{array}{c}-73,46^{*} \\
(2,1)\end{array}$ & - \\
\hline
\end{tabular}

Utilizamos teste de Kruskal-Wallis para avaliar se há diferença na distribuição de dispositivos por Título por estado. De forma análoga ao ANOVA utilizado as 
observações são a quantidade de dispositivos classificados segundo um Título e pertencentes a um estado. A variável de resposta é a quantidade de dispositivos e a independente utilizada para esse teste é a Unidade Federativa. Os estados foram codificados de 1 a 26 , o que resulta em variável nominal com 26 categorias distintas.

Análise de assimetria e curtose padronizadas indica que parte dos Estados pode ser aproximado por uma distribuição normal e parte não. Teste de Shapiro-Wilk rejeita a normalidade dos seguintes estados: $A L(p=, 039)$; $G O(p=, 019)$; $M S(p=$ ,025); PI ( $p=, 021) ; P R(p=, 034) ; R N(p=, 036) ; R R(p<, 001)$ e SP $(p=, 028)$. Para os demais estados não rejeitamos a hipótese de que segue uma normal. A análise dos diagramas de caixa indica certa semelhança entre os estados, sendo que o Título 3 é consistentemente um outlier. Por meio de teste de Levene $(p=0,99)$ não rejeitamos a hipótese de variâncias homogêneas. Sendo assim, por mais que não viole sistematicamente as condições de um teste ANOVA, a quantidade de categorias distintas sendo testada $(\mathrm{k}=26)$ e a quantidade reduzida de observações por grupo $\left(n_{k}=9\right)$ prejudicam o poder do teste.

Em virtude da quantidade reduzida de observações optamos pela simulação de Monte Carlo com 10.000 amostras e intervalo de confiança de 99\%. Não foi possível encontrar diferença estatisticamente significante nas distribuições, $H(25)=$ $13,34,, 973<p<, 981$.

Para testar se existe diferença significativa entre a composição proporcional das Constituições de Roraima e Distrito Federal e as demais Constituições Estaduais, utilizamos teste de Mann-Whitney em razão da assimetria no tamanho das amostras a serem comparadas, violação nos testes de normalidade e ausência de pressupostos acerca das distribuições. Para o caso de Roraima o teste de Mann-Whitney indica que a composição é distinta dos demais estados, $U=585,5, p=, 03$. Quando o teste é utilizado para testar o DF, não encontramos diferenças significativas, $U=963, p=$ ,808. 
Tabela A.7 - Sumário Estatístico da extensão, em dispositivos, dos Títulos Padronizados

\begin{tabular}{llllllllll}
\hline Títulos & Média & $\begin{array}{c}\text { Desvio } \\
\text { Padrão }\end{array}$ & $\begin{array}{c}\text { Coeficiente } \\
\text { de } \\
\text { Variação }\end{array}$ & Mediana & MADM & RMADM & Max & Min \\
\hline $\mathbf{1}$ & 25,81 & 20,67 & $80,08 \%$ & 20,50 & 11,50 & $56,10 \%$ & 88 & 1 \\
$\mathbf{2}$ & 213,85 & 60,52 & $28,30 \%$ & 221,00 & 41,50 & $18,78 \%$ & 327 & 83 \\
$\mathbf{3}$ & 421,50 & 55,84 & $13,25 \%$ & 423,00 & 39,50 & $9,34 \%$ & 531 & 319 \\
$\mathbf{4}$ & 24,04 & 8,00 & $33,29 \%$ & 23,00 & 6,00 & $26,09 \%$ & 39 & 10 \\
$\mathbf{5}$ & 121,46 & 41,20 & $33,92 \%$ & 127,50 & 16,00 & $12,55 \%$ & 184 & 26 \\
$\mathbf{6}$ & 118,35 & 60,45 & $51,08 \%$ & 101,00 & 43,00 & $42,57 \%$ & 283 & 30 \\
$\mathbf{7}$ & 217,50 & 71,16 & $32,72 \%$ & 206,00 & 45,50 & $22,09 \%$ & 368 & 93 \\
$\mathbf{8}$ & 24,23 & 24,01 & $99,10 \%$ & 17,00 & 16,50 & $97,06 \%$ & 79 & 0 \\
$\mathbf{9}$ & 97,69 & 43,21 & $44,23 \%$ & 91,50 & 17,50 & $19,13 \%$ & 228 & 23 \\
\hline
\end{tabular}




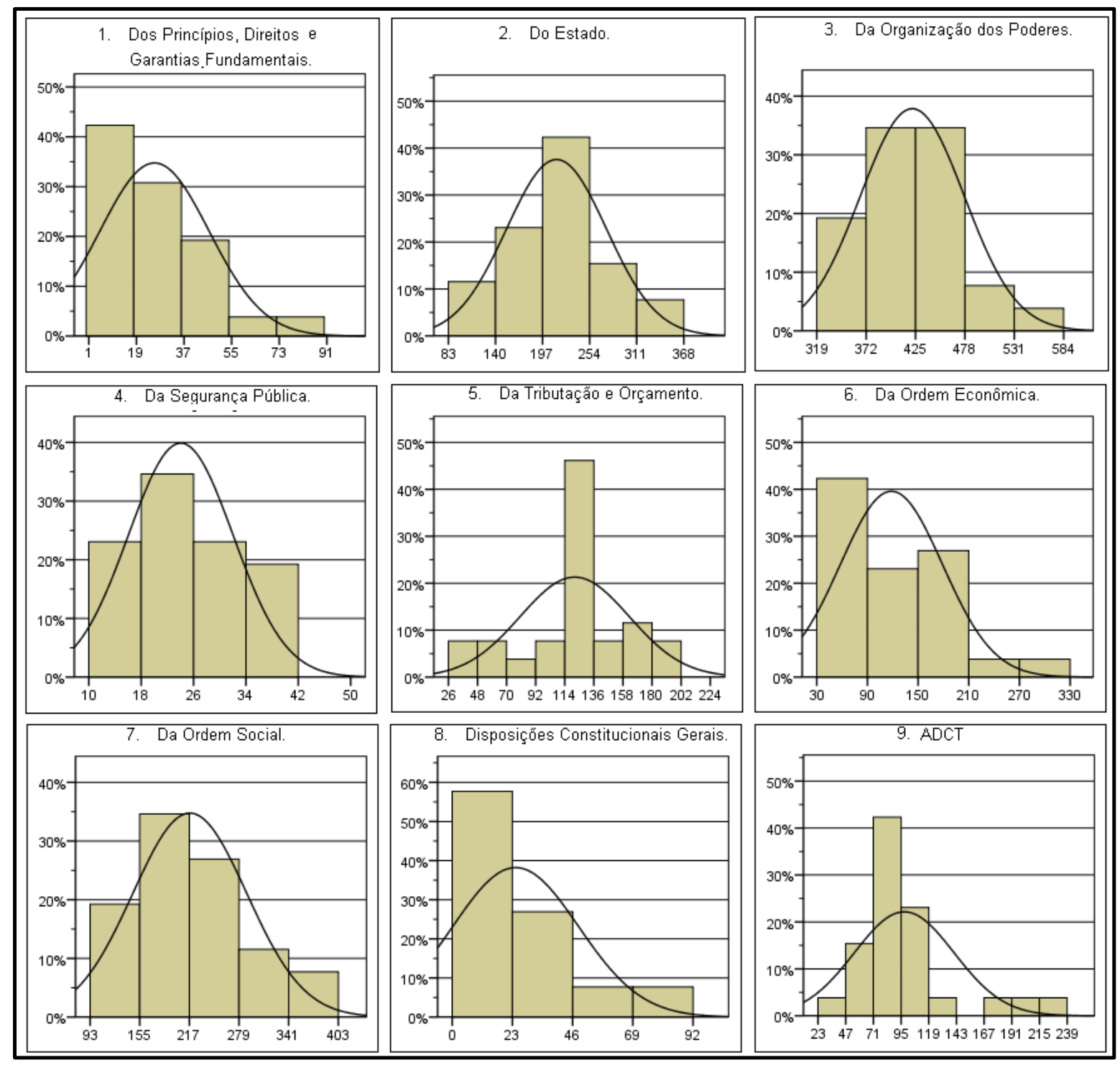

Gráfico A.4 - Histogramas de Frequência Relativa da extensão, em dispositivo, dos Títulos Padronizados 


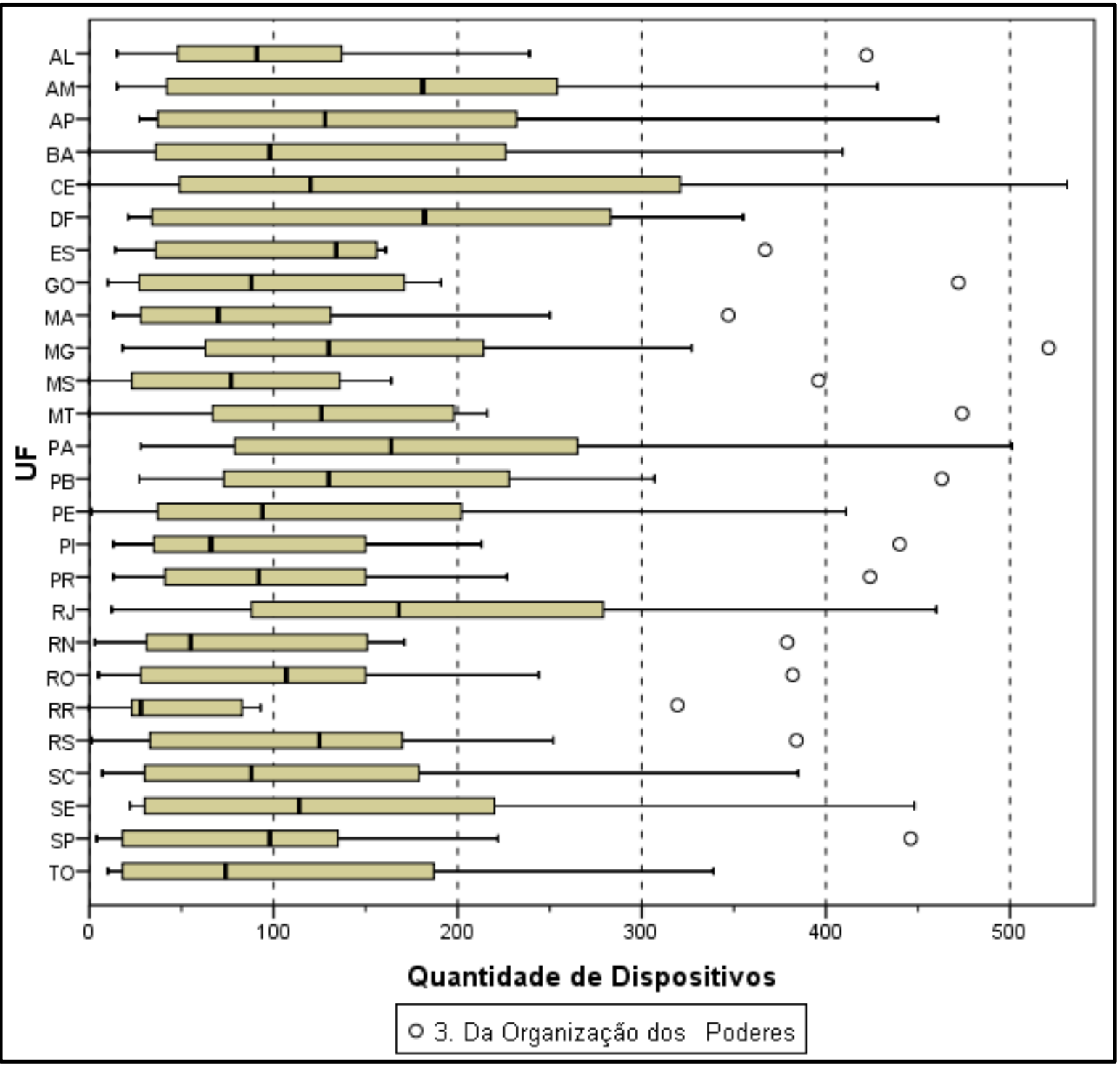

Gráfico A.5 - Diagramas de Caixa da Quantidade de Dispositivos por Título nas Constituições Estaduais 


\section{A.7 Estatísticas das Hipóteses avaliadas}

A Tabela A.8 expõe algumas estatísticas descritivas das variáveis que utilizamos para abordar nossas sete hipóteses bem como o nível de análise em que a variável foi medida e em quais hipóteses foram utilizadas. E em seguida apresentamos as tabelas de correlação utilizadas para fundamentar parte de nossa análise. Para as variáveis medidas em UF as observações correspondem aos valores encontrados em cada unidade federativa, para as variáveis medidas em Ano as observações correspondem ao total em cada ano e finalmente para as variáveis medidas em Legislatura as observações correspondem a cada legislatura de cada estado entre 1991 e 2014 ou seja, seis legislaturas. Uma característica marcante das variáveis que utilizamos são os desvios da normalidade, o que prejudica significativamente a utilização da correlação de Pearson. 
Tabela A.8 - Estatísticas Descritivas das Variáveis Desentendes e Independentes Abordadas.

\begin{tabular}{|c|c|c|c|c|c|c|c|}
\hline Variável & $\mathrm{N}$ & Média & Assimetria & Curtose & $\begin{array}{l}\text { Shapiro } \\
\text {-wilk (p) }\end{array}$ & Nível & Hipóteses \\
\hline $\begin{array}{l}\text { Dispositivos de Emenda às } \\
\text { CEs (UF) }\end{array}$ & 26 & $\begin{array}{c}370,31 \\
(194,75)\end{array}$ & $\begin{array}{c}0,61 \\
(0,46)\end{array}$ & $\begin{array}{l}-0,18 \\
(0,89)\end{array}$ & 0,2 & UF & $\begin{array}{l}\mathrm{H} 1 / \mathrm{H} 2 / \\
\mathrm{H} 3 / \mathrm{H} 4\end{array}$ \\
\hline Dispositivos nas CEs (1989) & 26 & $\begin{array}{l}1264,42 \\
(259,84)\end{array}$ & $\begin{array}{l}-0,21 \\
(0,46)\end{array}$ & $\begin{array}{l}-0,04 \\
(0,89)\end{array}$ & 0,06 & UF & $\mathrm{H} 3$ \\
\hline Policies nas CEs (1989) & 26 & $\begin{array}{c}417,85 \\
(111,62)\end{array}$ & $\begin{array}{c}0,02 \\
(0,46)\end{array}$ & $\begin{array}{l}-0,13 \\
(089)\end{array}$ & 0,4 & UF & $\mathrm{H} 4$ \\
\hline PIB 1989 (Ln; R\$ 2010) & 26 & $\begin{array}{l}24,15 \\
(1,15)\end{array}$ & $\begin{array}{c}0,39 \\
(0,46)\end{array}$ & $\begin{array}{l}0,16 \\
(0,89)\end{array}$ & 0,85 & UF & $\mathrm{H} 1$ \\
\hline PPC 1989 (Ln; R\$ 2010) & 26 & $\begin{array}{c}9,16 \\
(0,58)\end{array}$ & $\begin{array}{c}0,81 \\
(0,46)\end{array}$ & $\begin{array}{c}0,68 \\
(0,89)\end{array}$ & 0,2 & UF & $\mathrm{H} 1$ \\
\hline IDH (1991) & 26 & $\begin{array}{c}0,46 \\
(0,07)\end{array}$ & $\begin{array}{c}0,55 \\
(0,46)\end{array}$ & $\begin{array}{l}-0,55 \\
(0,89)\end{array}$ & 0,22 & UF & $\mathrm{H} 1$ \\
\hline GINI (1989) & 26 & $\begin{array}{l}60,1 \% \\
(5,32)\end{array}$ & $\begin{array}{l}-1,85 \\
(0,46)\end{array}$ & $\begin{array}{c}4,24 \\
(0,89)\end{array}$ & 0,01 & UF & $\mathrm{H} 2$ \\
\hline $\begin{array}{l}\text { Dispositivos de Emenda às } \\
\text { CEs (Anual) }\end{array}$ & 25 & $\begin{array}{c}384,84 \\
(261,01)\end{array}$ & $\begin{array}{c}1,1 \\
(0,47)\end{array}$ & $\begin{array}{c}1,49 \\
(0,91)\end{array}$ & 0,06 & Ano & H5 \\
\hline $\begin{array}{l}\text { Dispositivos de Emenda à } \\
\text { CF (Anual, defasado) }\end{array}$ & 25 & $\begin{array}{c}43,48 \\
(54,75)\end{array}$ & $\begin{array}{c}1,9 \\
(0,47)\end{array}$ & $\begin{array}{l}3,51 \\
(0,91)\end{array}$ & 0,01 & Ano & $\mathrm{H} 5$ \\
\hline $\begin{array}{l}\text { Dispositivos de Emenda às } \\
\text { CEs (Média Anual) }\end{array}$ & 25 & $\begin{array}{c}18,39 \\
(11)\end{array}$ & $\begin{array}{c}0,87 \\
(0,47)\end{array}$ & $\begin{array}{l}0,56 \\
(0,91)\end{array}$ & 0,08 & Ano & H5 \\
\hline $\begin{array}{l}\text { Dispositivos de Emenda às } \\
\text { CEs (Legislatura) }\end{array}$ & 154 & $\begin{array}{l}62,3 \\
(80)\end{array}$ & $\begin{array}{l}3,1 \\
(0,2)\end{array}$ & $\begin{array}{l}12,82 \\
(0,39)\end{array}$ & 0,01 & Legislatura & $\mathrm{H} 7$ \\
\hline $\begin{array}{l}\text { Emendas às Constituições } \\
\text { Estaduais (Legislatura) }\end{array}$ & 154 & $\begin{array}{l}9,42 \\
(6,4)\end{array}$ & $\begin{array}{l}1,12 \\
(0,2)\end{array}$ & $\begin{array}{c}1,63 \\
(0,39)\end{array}$ & 0,01 & Legislatura & $\mathrm{H} 7$ \\
\hline $\begin{array}{l}\text { Média de Dispositivos por } \\
\text { Emenda (Legislatura) }\end{array}$ & 154 & $\begin{array}{c}7,43 \\
(11,95)\end{array}$ & $\begin{array}{l}3,97 \\
(0,2)\end{array}$ & $\begin{array}{l}18,26 \\
(0,39)\end{array}$ & 0,01 & Legislatura & $\mathrm{H} 7$ \\
\hline $\begin{array}{l}\text { Dispositivos de Emendas } \\
\text { Estaduais (Ln; Legislatura) }\end{array}$ & 154 & $\begin{array}{c}3,42 \\
(1,34)\end{array}$ & $\begin{array}{l}-0,61 \\
(0,2)\end{array}$ & $\begin{array}{c}0,39 \\
(0,39)\end{array}$ & 0,01 & Legislatura & $\mathrm{H} 6$ \\
\hline $\begin{array}{l}\text { Porcentagem de Votos do } \\
\text { Governador Eleito }\end{array}$ & 154 & $\begin{array}{l}57,1 \% \\
(6,87)\end{array}$ & $\begin{array}{l}1,71 \\
(0,2)\end{array}$ & $\begin{array}{l}3,16 \\
(0,39)\end{array}$ & 0,01 & Legislatura & $\mathrm{H} 6$ \\
\hline $\begin{array}{l}\text { Proporção de Cadeiras da } \\
\text { Coligação do Governador }\end{array}$ & 154 & $\begin{array}{l}41,89 \% \\
(17,65)\end{array}$ & $\begin{array}{l}0,36 \\
(0,2)\end{array}$ & $\begin{array}{l}-0,48 \\
(0,39)\end{array}$ & 0,02 & Legislatura & $\mathrm{H} 6$ \\
\hline NEP & 154 & $\begin{array}{c}7,21 \\
(2,25)\end{array}$ & $\begin{array}{l}0,49 \\
(0,2)\end{array}$ & $\begin{array}{c}0,05 \\
(0,39)\end{array}$ & 0,03 & Legislatura & $\mathrm{H} 7$ \\
\hline NEC & 154 & $\begin{array}{c}4,56 \\
(1,75)\end{array}$ & $\begin{array}{l}0,79 \\
(0,2)\end{array}$ & $\begin{array}{c}0,45 \\
(0,39)\end{array}$ & 0,01 & Legislatura & $\mathrm{H} 7$ \\
\hline
\end{tabular}

Nota: Desvios Padrão em Parênteses 
Tabela A.9 - Hipóteses 1 e 2, coeficientes de Correlação

$\begin{array}{llll}\text { PIB } 1989 & \text { PPC } 1989 & \text { IDH } & \text { GINI }\end{array}$

(Ln; R\$ 2010) (Ln; R\$ 2010) (1991) (1989)

\begin{tabular}{lccccc}
\hline $\begin{array}{l}\text { Dispositivos } \\
\text { de Emenda } \\
\text { às CEs }\end{array}$ & $\begin{array}{c}\text { Correlação de } \\
\text { Pearson }\end{array}$ & $\begin{array}{c}0,074 \\
(0,72)\end{array}$ & $\begin{array}{c}0,114 \\
(0,58)\end{array}$ & $\begin{array}{r}0,107 \\
(0,6)\end{array}$ & $\begin{array}{l}0,036 \\
(0,86)\end{array}$ \\
& & & & & \\
& Rô de Spearman & $\begin{array}{c}0,082 \\
(0,69)\end{array}$ & $\begin{array}{c}0,164 \\
(0,42)\end{array}$ & $\begin{array}{c}0,176 \\
(0,39)\end{array}$ & 0,018 \\
& & & $(0,93)$ \\
\hline
\end{tabular}

Nota: P-Valor em parênteses

Tabela A.10 - Hipóteses 3 e 4, coeficientes de Correlação

\begin{tabular}{llcc}
\hline & \multicolumn{1}{c}{$\begin{array}{c}\text { Dispositivos nas CEs } \\
(\mathbf{1 9 8 9 )}\end{array}$} & $\begin{array}{c}\text { Policies nas CEs } \\
\mathbf{( 1 9 8 9 )}\end{array}$ \\
\hline $\begin{array}{l}\text { Dispositivos de } \\
\text { Emenda às CEs } \\
\text { (UF) }\end{array}$ & $\begin{array}{l}\text { Correlação de } \\
\text { Pearson }\end{array}$ & $\begin{array}{c}0,36 \\
(0,07)\end{array}$ & $\begin{array}{c}0,352 \\
(0,08)\end{array}$ \\
& & & \\
& Rô de & 0,253 & 0,272 \\
& Spearman & $(0,22)$ & $(0,18)$ \\
\hline
\end{tabular}

Nota: P-Valor em parênteses

Tabela A.11 - Hipótese 5, coeficientes de Correlação

\begin{tabular}{llcc}
\hline & & $\begin{array}{c}\text { Dispositivos de } \\
\text { Emenda às CEs } \\
\text { (Anual) }\end{array}$ & $\begin{array}{c}\text { Dispositivos de } \\
\text { Emenda às CEs } \\
\text { (Média Anual) }\end{array}$ \\
\hline $\begin{array}{llcc}\text { Dispositivos de } \\
\text { Emenda à CF }\end{array}$ & Correlação & 0,201 & 0,237 \\
(Anual, defasado) & de Pearson & $(0,32)$ & $(0,25)$ \\
& Rô de & 0,361 & 0,371 \\
& Spearman & $(0,07)$ & $(0,06)$ \\
\hline
\end{tabular}

Nota: P-Valor em parênteses 
Tabela A.12 - Hipótese 6, coeficientes de Correlação

\begin{tabular}{llcc}
\hline & & $\begin{array}{c}\text { Porcentagem de } \\
\text { Votos do } \\
\text { Governador Eleito }\end{array}$ & $\begin{array}{c}\text { Proporção de Cadeiras } \\
\text { da Coligação do } \\
\text { Governador }\end{array}$ \\
\hline $\begin{array}{l}\text { Dispositivos de } \\
\text { Emendas Estaduais } \\
\text { (Ln; Legislatura) }\end{array}$ & $\begin{array}{l}\text { Correlação } \\
\text { de Pearson }\end{array}$ & $\begin{array}{c}0,098 \\
(0,281)\end{array}$ & 0,101 \\
& Rô de & 0,11 & $(0,21)$ \\
Dispositivos de & Spearman & $(0,18)$ & 0,124 \\
$\begin{array}{l}\text { Emenda às CEs } \\
\text { (Legislatura) }\end{array}$ & Correlação & 0,101 & $(0,12)$ \\
& de Pearson & $(0,21)$ & 0,138 \\
& Rô de & 0,107 & $(0,09)$ \\
& Spearman & $(0,18)$ & 0,101 \\
\hline
\end{tabular}

Nota: P-Valor em parênteses

Tabela A.13 - Hipótese 7, coeficientes de Correlação

\begin{tabular}{llcc}
\hline & & NEP & NEC \\
\hline Dispositivos de Emenda às & Correlação de & 0,13 & 0,17 \\
CEs (Legislatura) & Pearson & $(0,1)$ & $(0,03)$ \\
& Rô de Spearman & 0,231 & 0,298 \\
& & $(0,01)$ & $(0,01)$ \\
Emendas às Constituições & Correlação de & 0,268 & 0,299 \\
Estaduais (Legislatura) & Pearson & $(0,01)$ & $(0,01)$ \\
& Rô de Spearman & 0,251 & 0,306 \\
& & $(0,01)$ & $(0,01)$ \\
Média de Dispositivos por & Pearson & $-0,041$ & 0,04 \\
Emenda (Legislatura) & & $(0,61)$ & $(0,62)$ \\
& Rô de Spearman & 0,153 & 0,192 \\
& & $(0,06)$ & $(0,02)$ \\
\hline
\end{tabular}

Nota: P-Valor em parênteses 


\section{Apêndice B - Modelo de Questionário de Coalizão}

O objetivo da pesquisa é identificar os Partidos Políticos que fizeram parte das coalizões de Governo na Assembleia Legislativa entre 1990 e 2014. Começando pelas eleições de 2010, observe os resultados abaixo e responda à pergunta na página seguinte:

\begin{tabular}{|l|l|c|}
\hline \multicolumn{1}{|c|}{ Candidatos } & \multicolumn{1}{c|}{ Eleições para Governador - 2010 } & \multicolumn{1}{c|}{$\begin{array}{c}\text { Coligação de votos } \\
\mathbf{1 0} \text { Turno }\end{array}$} \\
\hline $\begin{array}{l}\text { 1. Antônio Anastasia (Eleito) } \\
\text { (Antônio Augusto Junho Anastasia) }\end{array}$ & $\begin{array}{l}\text { Somos Minas Gerais } \\
\text { PP / PDT / PTB / PSL / PSC / PR / PPS / DEM / PSDC / PMN / PSB / PSDB }\end{array}$ & $\mathbf{6 2 , 7 6 \%}$ \\
\hline $\begin{array}{l}\text { 2. Hélio Costa } \\
\text { (Hélio Calixto Da Costa) }\end{array}$ & $\begin{array}{l}\text { Todos Juntos Por Minas } \\
\text { PRB / PT / PMDB / PC DO B }\end{array}$ & $34,18 \%$ \\
\hline
\end{tabular}

\begin{tabular}{|c|c|c|c|}
\hline \multicolumn{4}{|c|}{ Eleições para Assembleia Legislativa - 2010} \\
\hline Coligação/Partidos & $\%$ de & Coligação/Partidos & $\%$ de eleitos \\
\hline 1. PP / DEM / PSDB & $23,38 \%$ & $\begin{array}{l}\text { 8. Partido Do Movimento Democrático Brasileiro - } \\
\text { PMDB }\end{array}$ & $10,39 \%$ \\
\hline $\begin{array}{l}\text { 2. Muda Minas } \\
\text { PRB / PT }\end{array}$ & $16,88 \%$ & 9. Partido Verde - PV & $7,79 \%$ \\
\hline $\begin{array}{l}\text { 3. Justiça Social E Trabalho } \\
\text { PTB / PSB }\end{array}$ & $9,09 \%$ & 10. Partido Democrático Trabalhista - PDT & $6,49 \%$ \\
\hline $\begin{array}{l}\text { 4. Unidos Por Minas } \\
\text { PSL / PSDC / PMN }\end{array}$ & $6,49 \%$ & 11. Partido Popular Socialista - PPS & $3,90 \%$ \\
\hline 5. PRTB / PTC & $3,90 \%$ & 12. Partido Social Cristão - PSC & $2,60 \%$ \\
\hline 6. PTN / PHS & $2,60 \%$ & 13. Partido Comunista Do Brasil - PC do B & $2,60 \%$ \\
\hline $\begin{array}{l}\text { 7. Projeto Vitória } 2010 \\
\text { PRP / PT do B }\end{array}$ & $2,60 \%$ & 14. Partido Da República - PR & $1,30 \%$ \\
\hline
\end{tabular}


Por favor, assinale com um "X" na tabela abaixo os Partidos que fizeram parte da base aliada do Governo na Assembleia Legislativa, nos anos de 2011, 2012, 2013 e 2014. Para começar, já assinalamos para você o Partido do próprio Governador e pedimos que você assinale os que estiveram coligados com ele na Assembleia:

\begin{tabular}{|c|c|c|c|c|c|c|c|c|c|c|c|c|c|c|c|c|c|c|c|c|c|c|c|c|}
\hline & PP & DEM & PSDB & PRB & PT & PTB & PSB & PSL & PSDC & PMN & PRTB & PTC & |PTN & PHS & PRP & $\begin{array}{c}\text { PT } \\
\text { do B }\end{array}$ & PMDB & PV & PDT & PPS & PSC & $\begin{array}{c}\text { PC } \\
\text { do B }\end{array}$ & PROS & SDD \\
\hline $\begin{array}{c}2011 \\
\text { (Antônio Anastasia) }\end{array}$ & $X$ & $X$ & $x$ & & $X$ & $X$ & $x$ & & $x$ & $x$ & $x$ & & $x$ & $X$ & $X$ & $X$ & $x$ & $\mathbf{x}$ & $X$ & $X$ & $X$ & & & \\
\hline \begin{tabular}{|c|}
2012 \\
(Antônio Anastasia) \\
\end{tabular} & $X$ & X & $X$ & & $\mathbf{X}$ & X & & $X$ & $X$ & & $X$ & & $X$ & $x$ & $X$ & $X$ & $X$ & $x$ & $\mathbf{X}$ & $X$ & $X$ & & & $\mathbf{X}$ \\
\hline $\begin{array}{c}2013 \\
\text { (Antônio Anastasia) }\end{array}$ & $X$ & $X$ & $X$ & & $X$ & $X$ & & $x$ & $x$ & $x$ & $x$ & $x$ & $x$ & $x$ & $x$ & $X$ & $x$ & $x$ & $X$ & $x$ & $x$ & & & $X$ \\
\hline $\begin{array}{c}2014 \\
\text { (Alberto Coelho) }\end{array}$ & $X$ & $X$ & $X$ & & $X$ & X & & $X$ & $X$ & & $X$ & & & $x$ & $x$ & $x$ & $x$ & $x$ & $X$ & $X$ & $x$ & $X$ & $x$ & $X$ \\
\hline
\end{tabular}

Utilize as linhas abaixo para fazer suas observações, se necessário:

No período, manteve-se a tendência de afirmação de um amplo e sólido bloco governista, com a participação de quase todos os partidos com representação na Assembleia, mantendo-se a relação Executivo x Legislativo nos exatos moldes arquitetados desde o primeiro governo Aécio Neves (2003).

Na oposição ficaram apenas PT, PMDB, PRB e PCdoB, devendo-se registrar que mesmo nesses partidos, com exceção do PT, havia pontuais apoios de parlamentares a matérias de interesse do governo.

Verifica-se no período, além disso, uma retomada, em outros termos, das migrações partidárias após a introdução da Resolução TSE n 22.610, em 2007. Tanto se verificará acordos informais para desfiliação impune (casos, por exemplo, de Dinis Pinheiro ou Tenente Lúcio, entre outros), como a adesão a novos partidos: PSD, PEN, PROS e SDD. Houve dois casos de utilização de novo partido como ponte (João Vítor Xavier e Gustavo Valadares). 